\title{
4. HYDROTHERMAL TRANSITION TRANSECT (SITES 1023, 1024, AND 1025) ${ }^{1}$
}

\author{
Shipboard Scientific Party ${ }^{2}$
}

HOLE 1023A

Position: $47^{\circ} 55.040^{\prime} \mathrm{N}, 128^{\circ} 47.529^{\prime} \mathrm{W}$

Start hole: 0915 hr, 23 June 1996

End hole: 0215 hr, 25 June 1996

Time on hole: $41.00 \mathrm{hr}$ (1.71 days)

Seafloor (drill pipe measurement from rig floor, mbrf): 2604.2

Total depth (drill pipe measurement from rig floor, mbrf): 2798.7

Distance between rig floor and sea level (m): 10.9

Water depth (drill pipe measurement from sea level, m): 2593.3

Penetration (mbsf): 194.5

Coring totals:

Type: APC; Number: 14; Cored: $130.0 \mathrm{~m}$; Recovered: $134.25 \mathrm{~m}$ (103.3\%)

Type: XCB; Number: 8; Cored: 64.5 m; Recovered: $58.80 \mathrm{~m}(91.2 \%)$

Total: Number: 22; Cored: 194.5 m; Recovered: 193.05 m (99.3\%)

\section{Formation:}

Unit I: 0-190.17 mbsf; Quaternary Interbeds of sand and silt turbidites and hemipelagic mud

Unit II: 190.17-192.81 mbsf; Quaternary Hemipelagic mud

Unit 1: 192.81-194.5 mbsf; Quaternary Basalt

\section{HOLE 1024A}

Position: $47^{\circ} 54.522^{\prime} \mathrm{N}, 128^{\circ} 44.975^{\prime} \mathrm{W}$

Start hole: $0215 \mathrm{hr}, 25$ June 1996

End hole: 0915 hr, 25 June 1996

Time on hole: $7.00 \mathrm{hr}$ ( 0.29 days $)$

Seafloor (drill pipe measurement from rig floor, mbrf): 2623.3

Total depth (drill pipe measurement from rig floor, mbrf): 2632.5

Distance between rig floor and sea level (m): 10.9

Water depth (drill pipe measurement from sea level, m): 2612.4

Penetration (mbsf): 9.2

Coring totals:

Type: APC; Number: 1; Cored: 9.2 m; Recovered: 9.18 m (99.8\%)

Formation:

Unit I: 0-9.2 mbsf; Quaternary

Interbeds of sand and silt turbidites and hemipelagic mud
HOLE 1024B

Position: $47^{\circ} 54.274^{\prime} \mathrm{N}, 128^{\circ} 45.132^{\prime} \mathrm{W}$

Start hole: 0915 hr, 25 June 1996

End hole: 0900 hr, 26 June 1996

Time on hole: $23.75 \mathrm{hr}$ ( 0.99 days)

Seafloor (drill pipe measurement from rig floor, mbrf): 2624.9

Total depth (drill pipe measurement from rig floor, mbrf): 2794.6

Distance between rig floor and sea level (m): 10.9

Water depth (drill pipe measurement from sea level, m): 2614.0

Penetration (mbsf): 169.6

Coring totals:

Type: APC; Number: 13; Cored: 121.6 m; Recovered: 123.31 m (101.4\%)

Type: XCB; Number: 5; Cored: 48.0 m; Recovered: 46.80 m (97.5\%)

Total: Number: 18; Cored: $169.6 \mathrm{~m}$; Recovered: $170.11 \mathrm{~m}$ (100.3\%)

Formation:

Unit I: 0-149.7 mbsf; Quaternary Interbeds of sand and silt turbidites and hemipelagic mud

Unit II: 149.7-167.82 mbsf; Quaternary Hemipelagic mud

Unit 1: 167.82-169.6 mbsf; Quaternary Basalt

\section{HOLE 1025A}

Position: $47^{\circ} 53.247^{\prime} \mathrm{N}, 128^{\circ} 38.920^{\prime} \mathrm{W}$

Start hole: $0900 \mathrm{hr}, 26$ June 1996

End hole: 1745 hr, 26 June 1996

Time on hole: $8.75 \mathrm{hr}$ ( 0.36 days)

Seafloor (drill pipe measurement from rig floor, mbrf): 2617.2

Total depth (drill pipe measurement from rig floor, mbrf): 2623.5

Distance between rig floor and sea level (m): 11.0

Water depth (drill pipe measurement from sea level, m): 2606.2

Penetration (mbsf): 6.3

Coring totals:

Type: APC; Number: 1; Cored: 6.3 m; Recovered: 6.34 m (100.6\%)

Formation:

Unit I: 0-6.3 mbsf; Quaternary

Interbeds of sand and silt turbidites and hemipelagic mud

\section{HOLE 1025B}

Position: $47^{\circ} 52.998^{\prime} \mathrm{N}, 128^{\circ} 39.052^{\prime} \mathrm{W}$

Start hole: 1745 hr, 26 June 1996 
End hole: 1345 hr, 27 June 1996

Time on hole: $20.00 \mathrm{hr}$ (0.83 days)

Seafloor (drill pipe measurement from rig floor, mbrf): 2624.5

Total depth (drill pipe measurement from rig floor, mbrf): 2724.0

Distance between rig floor and sea level (m): 10.9

Water depth (drill pipe measurement from sea level, m): 2613.6

Penetration (mbsf): 99.5

Coring totals:

Type: APC; Number: 8; Cored: 71.5 m; Recovered: 74.33 m (104.0\%)

Type: XCB; Number: 3; Cored: 28.0 m; Recovered: 16.65 m (59.5\%)

Total: Number: 11; Cored: 99.5; Recovered: 91.05 m (91.5\%)

Formation:

Unit I: 0-87.61 mbsf; Quaternary Interbeds of sand and silt turbidites and hemipelagic mud

Unit II: 87.61-97.48 mbsf; Quaternary Hemipelagic mud

Unit 1: 97.48-99.5 mbsf; Quaternary Basalt

\section{HOLE 1025C}

Position: $47^{\circ} 53.247^{\prime} \mathrm{N}, 128^{\circ} 38.919^{\prime} \mathrm{W}$

Start hole: 1345 hr, 27 June 1996

End hole: 0245 hr, 30 June 1996

Time on hole: $61.0 \mathrm{hr}$ (2.54 days)

Seafloor (drill pipe measurement from rig floor, mbrf): 2617.2

Total depth (drill pipe measurement from rig floor, mbrf): 2723.3

Distance between rig floor and sea level (m): 11.0

Water depth (drill pipe measurement from sea level, m): 2606.2

Penetration (mbsf): 106.1

Coring totals:

Type: 143/4-in tricone; Number: 0; Cored: 0.0 m; Recovered: 0 m $(0.0 \%)$

\section{HOLE 1024C}

Position: $47^{\circ} 54.531^{\prime} \mathrm{N}, 128^{\circ} 45.005^{\prime} \mathrm{W}$

Start hole: 2230 hr, 22 July 1996

End hole: 1915 hr, 26 July 1996

Time on hole: $92.75 \mathrm{hr}$ (3.86 days)

Seafloor (drill pipe measurement from rig floor, mbrf): 2623.3

Total depth (drill pipe measurement from rig floor, mbrf): 2797.0

Distance between rig floor and sea level (m): 11.1

Water depth (drill pipe measurement from sea level, m): 2612.2

Penetration (mbsf): 173.7

Coring totals:

Type: 14-3/4-in tricone; Number: 0; Cored: 0.0 m; Recovered: 0 m $(0.0 \%)$

\section{HOLE 1025C}

Position: $47^{\circ} 53.247^{\prime} \mathrm{N}, 128^{\circ} 38.919^{\prime} \mathrm{W}$

Continue hole: 1345 hr, 27 July 1996

End hole: 0215 hr, 31 July 1996
Time on hole: $118.50 \mathrm{hr}$ (4.94 days)

Seafloor (drill pipe measurement from rig floor, mbrf): 2617.2

Total depth (drill pipe measurement from rig floor, mbrf): 2764.4

Distance between rig floor and sea level (m): 11.2

Water depth (drill pipe measurement from sea level, m): 2606.0

Penetration (mbsf): 147.2

Coring totals:

Type: RCB; Number: 5; Cored: 41.1 m; Recovered: 15.16 m (36.9\%)

Formation:

Unit 1: 106.1-147.2 mbsf; Quaternary

Basalt

\section{HOLE 1024C}

Position: $47^{\circ} 54.531^{\prime} \mathrm{N}, 128^{\circ} 45.005^{\prime} \mathrm{W}$

Continue hole: 1415 hr, 30 July 1996

End hole: 0845 hr, 2 August 1996

Time on hole: $66.5 \mathrm{hr}$ (2.77 days)

Seafloor (drill pipe measurement from rig floor, mbrf): 2623.3

Total depth (drill pipe measurement from rig floor, mbrf): 2797.0

Distance between rig floor and sea level (m): 11.1

Water depth (drill pipe measurement from sea level, m): 2612.2

Penetration (mbsf): 173.7

Coring totals:

Type: RCB; Number: 1; Cored: 2.0 m; Recovered: 0.12 m (6.0\%)

Formation:

Unit 1; 173.7-175.7 mbsf; Quaternary

Basalt

\section{GEOLOGIC CONTEXT}

Objectives for drilling along the Hydrothermal Transition Transect (Sites 1023, 1024, and 1025) are discussed in detail in the "Introduction and Summary" chapter (this volume). In brief, the holes were drilled to study the influence of hydrothermal circulation, close to a region of extensive basement outcrop, on physical and chemical fluxes in the upper igneous crust beneath an area of relatively thick and continuous sediment cover. The geologic context of the holes is shown in Figures 1 and 2, which illustrate well the abrupt and simple onlap of turbidite sediments onto the elevated basement topography of the Juan de Fuca Ridge (also see Fig. 5, "Introduction and Summary" chapter [back-pocket foldout]).

West of a point roughly $19 \mathrm{~km}$ from the ridge axis, along the seismic profile shown in Figure 2, the igneous crust is covered discontinuously by only a few to a few tens of meters of sediment. In this area, exchange of water between the permeable upper crust and the ocean is relatively unrestricted, as is confirmed by the chemistry of basement fluids estimated from shallow cores (Wheat and Mottl, 1994). To the east of this point, the igneous crust is largely buried, and thought to be hydrologically sealed, by turbidite sediments of Cascadia Basin. The sediment thickness in this area ranges most typically between 100 and $200 \mathrm{~m}$. As inferred from the seafloor bathymetry, which probably reflects the sediment distribution pattern at the end of the last glacial interval (roughly $10 \mathrm{ka}$ ), turbidite sediments have entered the area from the north via four distributary channels. The westernmost can be traced through Middle Valley, the site of drilling during Legs 139 and 169. This channel merges with a second at the latitude of the Hydrothermal Transition drilling transect. These 


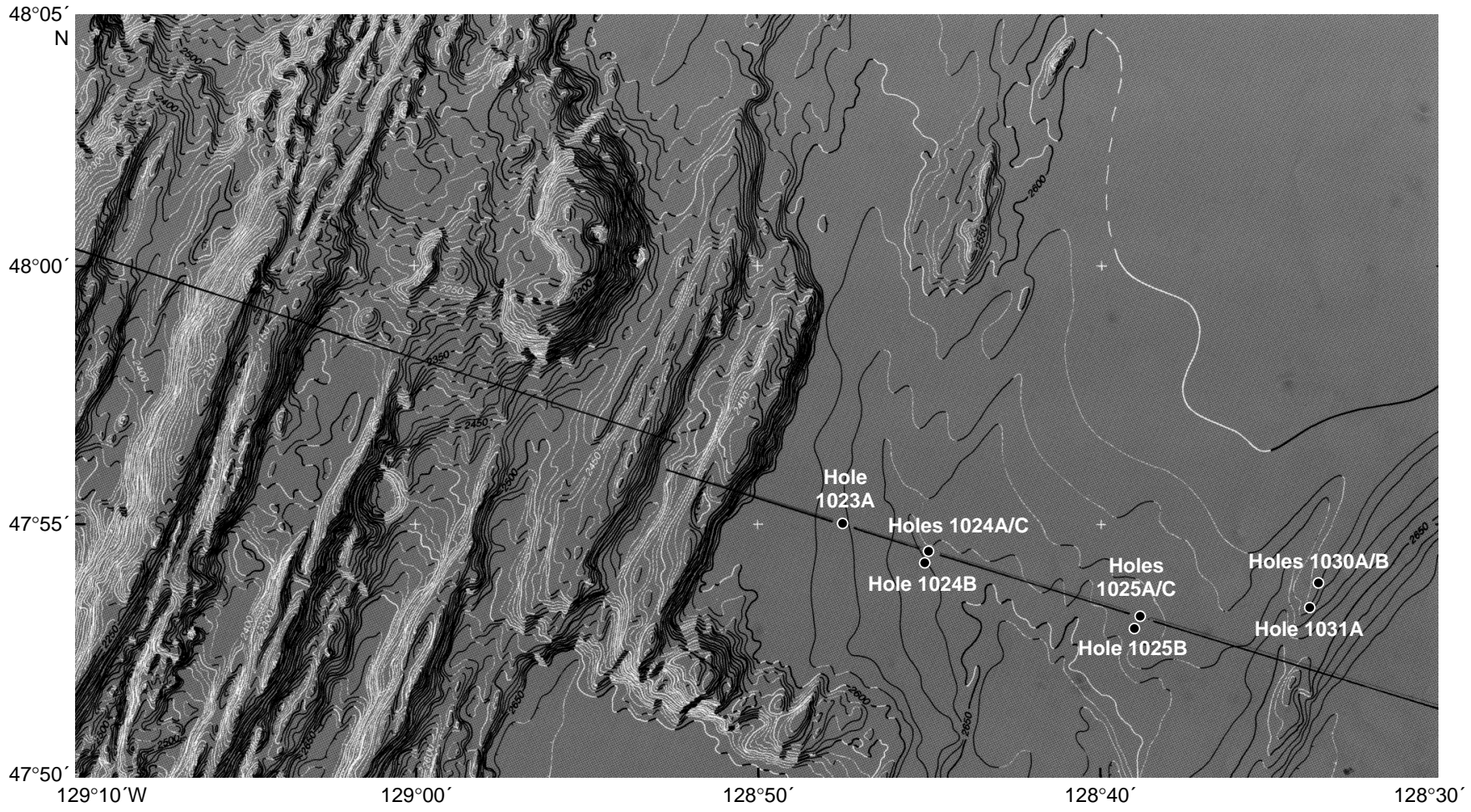

Figure 1. Seafloor bathymetry of the Hydrothermal Transition drilling transect. Contours are given at 10-m intervals and calculated assuming a sound velocity of $1500 \mathrm{~m} / \mathrm{s}$. Hole locations and trackline of seismic reflection profile (Fig. 2; also see Fig. 5, "Introduction and Summary" chapter [back-pocket foldout]) are indicated. The seismic trackline crosses the ridge axis at approximately $48^{\circ} \mathrm{N}, 129^{\circ} 05^{\prime} \mathrm{W}$.

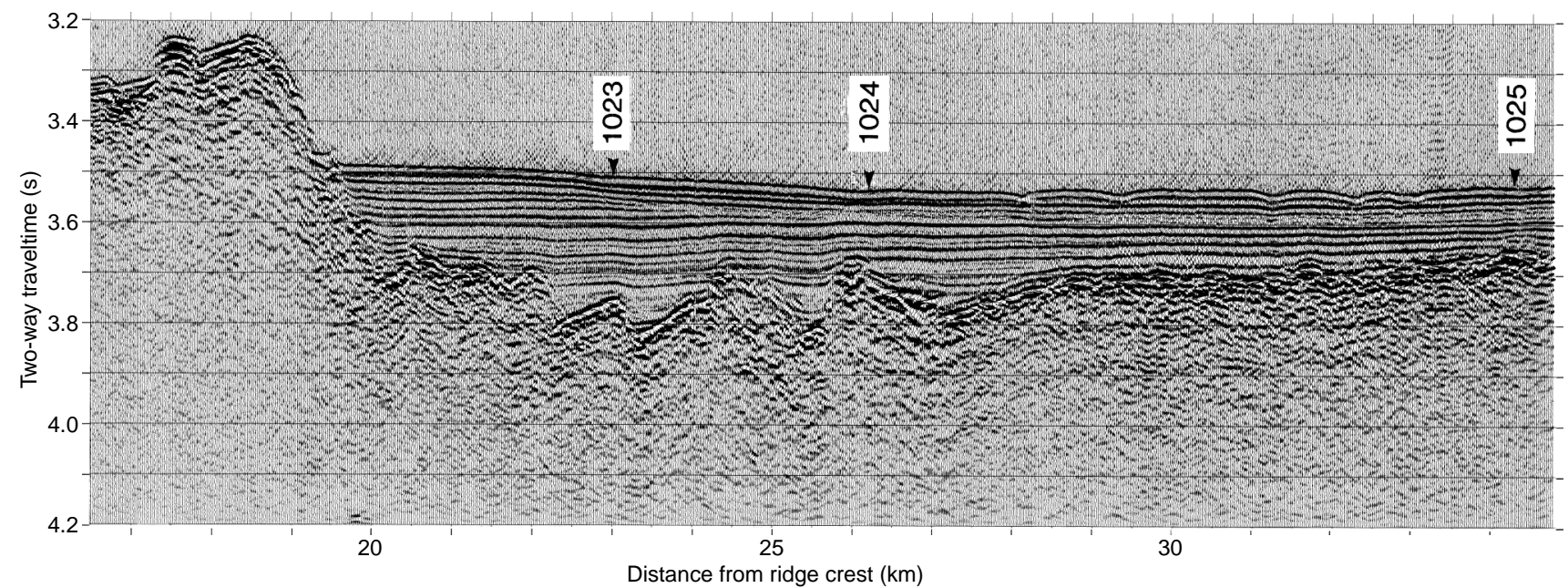

Figure 2. Seismic reflection profile along which the Hydrothermal Transition drilling sites were located. Distances along the profile are given relative to the axis of the Juan de Fuca Ridge (see Fig. 1). Ages are given in the "Introduction and Summary" chapter (this volume), and heat flow along the line is given in Davis et al. (this volume). Seismic data here and in Figure 3 were collected using a 1.5-L (90-in $\left.{ }^{3}\right)$ Generator-Injector gun source and a digital acquisition and processing system operated by the University of Bremen.

channels, in turn, merge with two others seen at the eastern edge of the area (Fig. 1) farther to the south. Despite this complexity, the seafloor relief is, in fact, quite subdued, with gradients typically less than $1: 100$. Likewise, the underlying sedimentary structure is generally simple and continuous. Seismic reflectors are very close to parallel and horizontal, and they intersect basement discontinuously.

Local basement relief is also relatively gentle. Block faulting at the western end of the transect produces local structural offsets of typically less than $100 \mathrm{~m}$. Farther to the east, the basement topography is more subdued, perhaps because of late-stage burial by post-rift volcanism. At the eastern end of the area, a local volcanic ridge shoals to within about $50 \mathrm{~m}$ of the sediment surface. Sites 1030 and 1031 were drilled along this ridge (Fig. 1; also see "Buried Basement Transect" chapter, this volume).

Heat flow along this transect shows a systematic increase with distance from the point where the turbidites onlap onto basement 
(Fig. 2). This increase is in the opposite sense of that which would be expected if the heat flow simply reflected the cooling of the underlying lithosphere, which increases in age from $0.8 \mathrm{Ma}$ at the point of sediment onlap to about 1.4 Ma at the east end of the transect. Low heat-flow values near outcropping basement are only about $15 \%-$ $20 \%$ of the lithospheric level predicted by simple cooling theory; heat flow reaches about $80 \%$ of the level expected at a distance of $20 \mathrm{~km}$ from the region of outcrop (Fig. 7, "Introduction and Summary" chapter, this volume).

Other changes that are observed or inferred over this same distance include (1) a systematic increase in seismic velocity of the upper igneous crustal seismic Layer 2a, which increases from less than $3.5 \mathrm{~km} / \mathrm{s}$ in the region of outcrop to more than $5 \mathrm{~km} / \mathrm{s} 20 \mathrm{~km}$ to the east (see Fig. 7, "Introduction and Summary" chapter, this volume; (2) changes in basement-fluid composition (Wheat and Mottl, 1994), and perhaps most diagnostic of all, (3) an increase in the temperature of the upper basement surface, estimated from seafloor heat-flow and local sediment-thickness observations (Fig. 7, "Introduction and Summary" chapter, this volume). All changes are inferred to be associated with the transition from sediment-free to sediment-sealed hydrothermal conditions in the upper igneous crust, with the influence of active seawater/basement water exchange being felt to a diminishing extent with increasing distance from the region of outcrop.

It was anticipated that Sites 1023, 1024, and 1025 would allow these changes to be documented and the processes involved constrained in a quantitative way. Holes were positioned both with temperature and distance from outcrop in mind (Fig. 2). Site 1023 is located just $3.5 \mathrm{~km}$ east of the sediment/basement onlap, and basement was intersected at a temperature of $15.5^{\circ} \mathrm{C}$. Site 1024 is located 6.7 $\mathrm{km}$ east of the onlap point, and basement was intersected at $22.8^{\circ} \mathrm{C}$. Site 1025 is located $14.7 \mathrm{~km}$ from the onlap point, and basement was intersected at $38.6^{\circ} \mathrm{C}$ where the heat flow approaches roughly $80 \%$ of the lithospheric value.

All three holes were sited over basement ridges (Fig. 2). This was done to (1) minimize drilling time; (2) ensure that all observations along the transect would be made in locally similar hydrologic settings, so that the larger scale variations in temperature, pressure, fluid chemistry, and basement and sediment alteration could be more confidently resolved; and (3) minimize the risk of intersecting massive volcanic flow units that might have been erupted off-axis and ponded in basement lows. Sediment thickness was well defined by the seismic data at each of the holes (Fig. 3) except in the cases of Holes $1024 \mathrm{~B}$ and $1025 \mathrm{~B}$, which, for hydrologic and logistical reasons, were located $500 \mathrm{~m}$ from the locations of the primary reentry holes at these sites, and thus midway between seismic reflection profile locations (Fig. 4). Basement was intersected at these holes at depths that generally agreed with the along-strike plunge of structures defined by the adjacent seismic profiles.

\section{OPERATIONS \\ Site 1023}

Fresh northerly head winds were encountered while transiting to Site 1023 (proposed site HT-2A), slowing the vessel's speed occasionally to less than $9 \mathrm{kt}$. Conditions continued to moderate throughout the transit, and speeds improved to $11 \mathrm{kt}$ on the final day. A standard advanced hydraulic piston corer/extended core barrel (APC/ $\mathrm{XCB}$ ) bottom-hole assembly (BHA) was deployed without a nonmagnetic drill collar or lockable float valve because core orientation and wireline logging were not scheduled for any of the Hydrothermal Transition sites. Rig floor operations were slowed on the initial pipe trip for several reasons. This was the initial pipe trip of the leg, and the stands of drill pipe had to be measured (strapped) and an adequate internal diameter verified (rabbited). A drill-string wiper plug (pig) was pumped to remove any loose scale residing in the pipe. In addi- tion, a new driller and assistant driller were being trained. Operations went exceptionally well with no major problems or incidents. The mudline was verified $5.2 \mathrm{~m}$ higher than indicated by the precision depth recorder (PDR) (Table 1). Hole conditions were excellent, and no drilling mud was required. Seawater was the only circulation fluid used. Basement was encountered at $192.81 \mathrm{mbsf}$.

\section{Site 1024}

\section{Hole 1024A}

After releasing and recovering the beacon at Site 1023 (HT-2A), the ship was moved in dynamic positioning (DP) mode using the differential Global Positioning System (DGPS) to the location coordinates for Site 1024 (proposed site HT-3A). A single piston core was taken only to define the mudline for the jet-in test (Table 1). The mudline was verified $7.1 \mathrm{~m}$ higher than the PDR indicated. A jet-in test was conducted to 38.5 meters below seafloor (mbsf) in $55.5 \mathrm{~min}$., using a maximum $22 \mathrm{spm}$. This information was used to determine the amount of 16-in casing (conductor pipe) to be deployed with the reentry cone on Hole $1024 \mathrm{C}$.

\section{Hole 1024B}

The ship was offset in DP mode $500 \mathrm{~m}$ to the south-southwest $\left(200^{\circ}\right)$ before Hole 1024B was spudded. The hole was located as far as possible from the coordinates of the primary Circulation Obviation Retrofit Kit (CORK) hole. The move was made with the DP suspended on knobby drilling joints through the guide horn and with the bit a minimum $100 \mathrm{~m}$ above the relatively flat seafloor. Based on the APC spud core, the mudline was verified $7.5 \mathrm{~m}$ above that indicated by the PDR. Hole conditions were again excellent, and no drilling mud was required. The hole was displaced with weighted $(10.5 \mathrm{lb} / \mathrm{gal}) \mathrm{gel}$ mud after reaching basement depth. Operations went exceptionally well with no major problems or incidents.

\section{Site 1025}

\section{Hole 1025A}

After releasing and recovering the beacon at Site 1024, the ship was moved in DP mode using DGPS to the coordinates for Site 1025 (proposed site HT-4A). A single piston core was taken to define the mudline for the jet-in test (Table 1). The mudline was verified $6.2 \mathrm{~m}$ higher than the PDR indicated. A jet-in test was conducted to 39.7 mbsf, using a maximum of $60 \mathrm{spm}$, and completed in $3 \mathrm{hr}, 18 \mathrm{~min}$. This information was used to determine the amount of 16-in casing (conductor pipe) to be deployed with the reentry cone on Hole $1025 \mathrm{C}$.

\section{Hole 1025B}

The ship was offset in DP mode $500 \mathrm{~m}$ to the south-southwest $\left(200^{\circ}\right)$ before Hole $1025 \mathrm{~B}$ was spudded. The hole was located as far as possible from the coordinates of the primary CORK hole. The move was made with the DP suspended on knobby drilling joints through the guide horn and the bit a minimum $100 \mathrm{~m}$ above the relatively flat seafloor. Based on the APC spud core, the mudline was verified $3.9 \mathrm{~m}$ above that indicated by the PDR. Hole conditions remained excellent, and no drilling mud was required. The hole was displaced with weighted $(10.5 \mathrm{lb} / \mathrm{gal})$ gel mud after reaching basement depth. Operations went exceptionally well with no major problems or incidents.

\section{Hole $1025 C$}

Before Hole $1025 \mathrm{C}$ was spudded, the ship was moved in DP mode $500 \mathrm{~m}$ back to the original coordinates for Hole 1025A. A reentry 

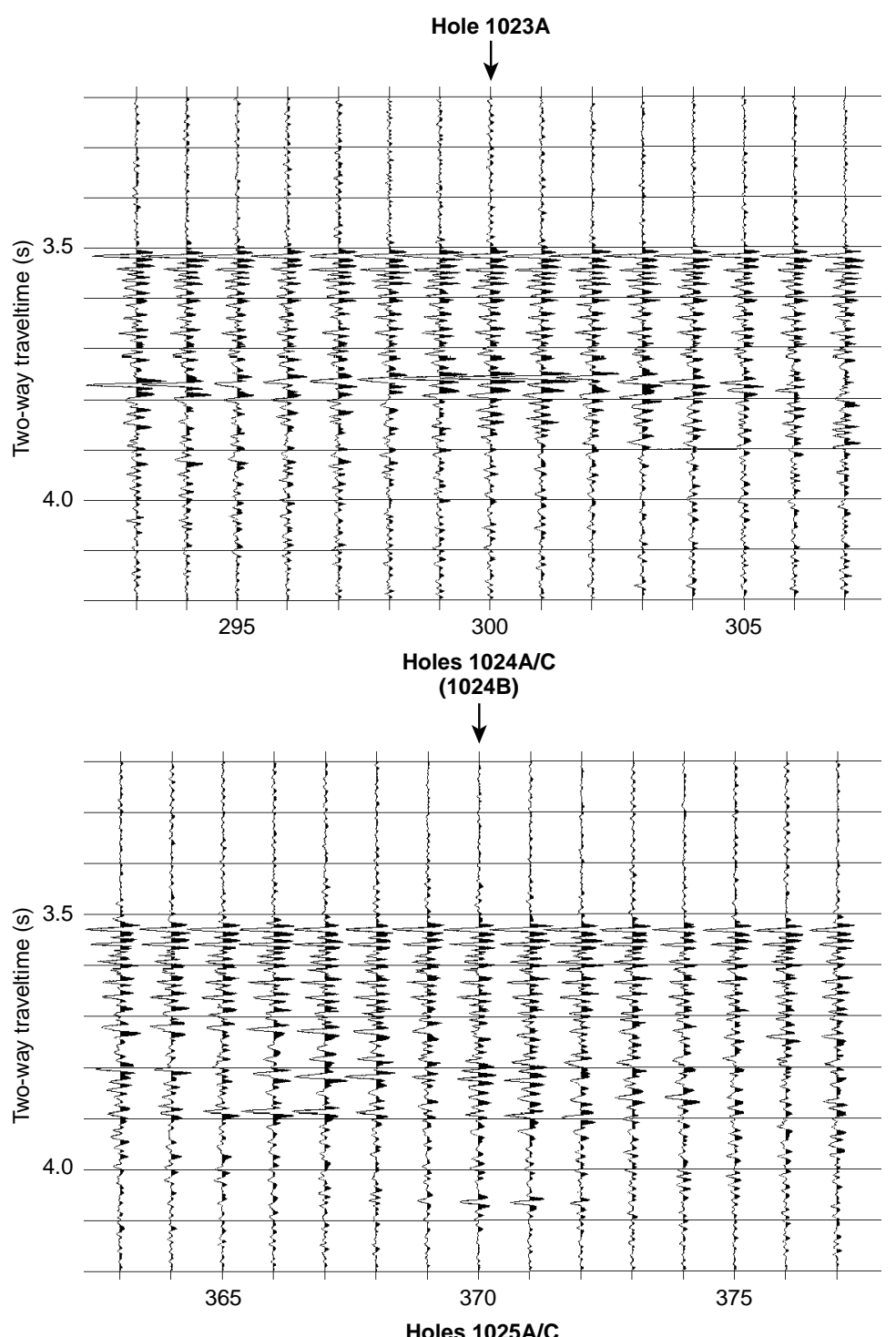

(1025B)

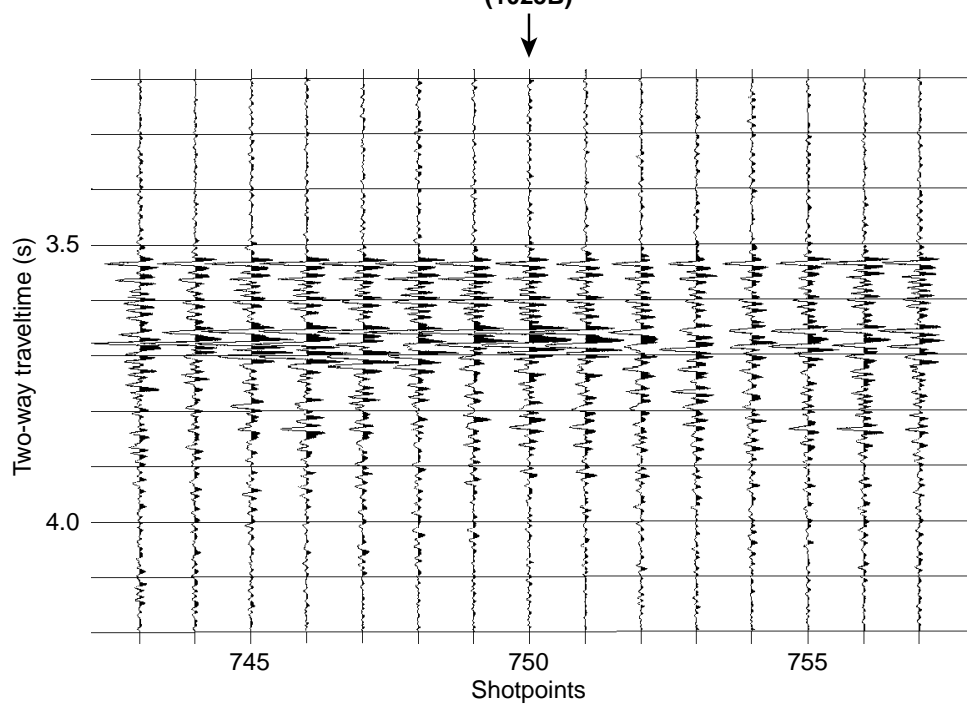

Figure 3. Trace-by-trace seismic reflection data in the immediate vicinity of Holes 1023A, 1024C, and 1025C. Shots are spaced $25 \mathrm{~m}$ apart. Holes $1024 \mathrm{~B}$ and 1025B are located $500 \mathrm{~m}$ off profile (see Fig. 4). 


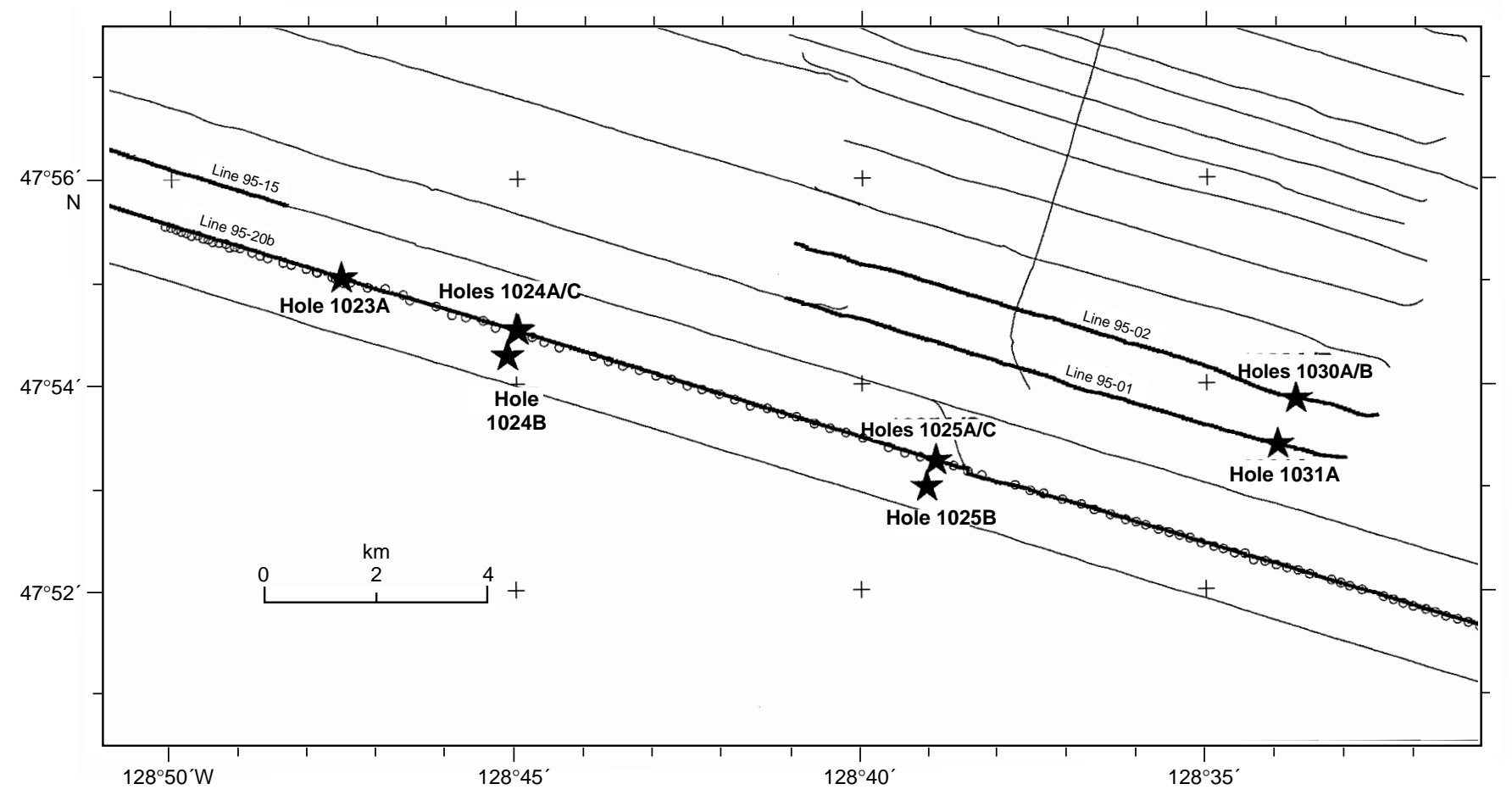

Figure 4. Hole positions along the Hydrothermal Transition Transect, along with seismic profile locations, including Sites 1030 and 1031 of the Buried Basement Transect.

cone and 16-in conductor pipe were deployed and washed into the seafloor without incident. The 16-in casing shoe was placed at 2657.4 $\mathrm{m}$ (40.2 mbsf). The Dril-Quip 16-in running tool was released from the reentry cone/casing. The running tool had been dressed with the cam-actuated drilling apparatus option allowing the 143/4-in tricone drill bit to be advanced downhole. A 143/4-in hole for the 103/4-in surface casing string was drilled to $106.1 \mathrm{mbsf}$ (5.1 m into basement). Two meters of hard fill was found in the hole after picking up the drill string for a connection. Drilling progress slowed noticeably at that point, and it was decided to not pursue deepening the hole further. The hole was flushed with a 30-bbl sweep of sepiolite mud, and the bit was pulled to $2644.0 \mathrm{~m}$ (up inside the 16-in conductor casing). To allow time for any fill to settle in the hole, the top drive was set back and the drilling line was slipped and cut. Approximately $2.5 \mathrm{hr}$ later, the second half of the wiper trip was begun. The pipe was run to the original total depth (TD) of $2723.3 \mathrm{~m}$ (106.1 mbsf) without any resistance. Encouraged by the apparent stability, we left the hole filled with seawater, and the drill string was tripped back to the surface. A 98.8-m-long string of $40.5 \mathrm{lb} / \mathrm{ft}$ 103/4-in K-55 casing was then made up and run to bottom. Reentry took $1 \mathrm{hr}$ partially because of obscured vision from sediment clouds emanating from the reentry cone. Apparently, formation water was beginning to flow up the hole and discharge at the seafloor. Once the hole was reentered, the casing went smoothly downhole without any problem. Approximately $4 \mathrm{~m}$ short of landing the casing hanger, the drill pipe was hung off at the rotary table. The top drive was picked up along with the TIW subsea-release cementing manifold and a $30-\mathrm{ft}$ knobby drilling joint. With the heave compensator activated, the $103 / 4$-in casing hanger was landed and latched. A 10,000-lb tension was taken on the hanger to verify proper latch-in. With the 103/4-in casing shoe placed at $2718.7 \mathrm{~m}(101.5 \mathrm{mb}-$ sf), 44 bbl of 15.8-ppg class $\mathrm{G}$ neat cement was mixed and displaced around the casing shoe. With $5000 \mathrm{lb}$ of tension applied, the drill string was rotated $3 \frac{1}{2}$ turns to the right. After a few minutes of working the pipe and releasing the torque buildup, the Dril-Quip running tool spun freely. A $12,000-1 b$ weight loss indicated that the casing was free of the drill string, and the pipe was tripped back to the surface. The drill floor was secured for transit, the positioning beacon was commanded off, and the vessel then got under way for proposed site PP-5A (Site 1026). Operations moved to the Rough Basement Transect area to allow the cement ample time to cure and, thus, to increase the chance for a better seal. This strategy was used for all the cased/CORKed holes, and it enabled us to use the time spent waiting for cement to cure to complete coring and casing at nearby holes.

\section{Site 1024}

\section{Hole $1024 C$}

Because of poor weather conditions, we had to delay the installation of the CORK at Site 1026. Therefore, we decided to move back to Site 1024 and set what had become the fourth reentry cone of the leg in preparation for installing the CORK. After preparation, the cone with a 16-in conductor pipe was run to bottom. The jetting operation required a maximum of $46 \mathrm{spm}$ and was completed in $2 \mathrm{hr}, 44$ min. With the reentry cone landed at the mudline, the 16-in casing shoe was placed at $2662.5 \mathrm{~m}$ (39.2 mbsf). The Dril-Quip 16-in running tool was easily released from the reentry cone and casing. The drill string was recovered, the 16-in Dril-Quip running tool was detorqued at the rig floor, and a 143/4-in drilling assembly with a tricone bit was made up. The assembly was lowered to the seafloor, and after deploying the vibration-isolated television (VIT) frame a routine reentry was made in $30 \mathrm{~min}$. The drilling rate to basement was fairly rapid at first. Drilling continued at an average rate of penetration (ROP) of $30 \mathrm{~m} / \mathrm{hr}$ until a depth of $2775.0 \mathrm{~m}$ (151.7 mbsf) was reached. After the drilling break, the ROP slowed to 1-2 $\mathrm{m} / \mathrm{hr}$ until TD was reached at a depth of $2797.0 \mathrm{~m}$ (173.7 mbsf), $22.0 \mathrm{~m}$ into hard rock. In the lower part of the hole, the drilling was characterized by high torque and some pipe sticking, but only on bottom. The drilling parameters rapidly returned to normal once the bit was lifted off bottom. At the conclusion of drilling, the hole was circulated with seawater, and a wiper trip was made to the 16 -in casing shoe. During 
Table 1. Coring summary for Sites 1023 through 1025.

\begin{tabular}{|c|c|c|c|c|c|c|}
\hline Core & $\begin{array}{c}\text { Date } \\
(1996)\end{array}$ & $\begin{array}{l}\text { Time } \\
\text { (UTC) }\end{array}$ & $\begin{array}{l}\text { Depth } \\
\text { (mbsf) }\end{array}$ & $\begin{array}{l}\text { Length } \\
\text { cored } \\
(\mathrm{m})\end{array}$ & $\begin{array}{l}\text { Length } \\
\text { recovered } \\
(\mathrm{m})\end{array}$ & $\begin{array}{c}\text { Recovery } \\
(\%)\end{array}$ \\
\hline \multicolumn{7}{|l|}{ 168-1023A- } \\
\hline $1 \mathrm{H}$ & 24 June & 0345 & $0.0-9.3$ & 9.3 & 9.34 & 100.0 \\
\hline $2 \mathrm{H}$ & 24 June & 0445 & $9.3-18.8$ & 9.5 & 9.45 & 99.5 \\
\hline $3 \mathrm{H}$ & 24 June & 0600 & $18.8-28.3$ & 9.5 & 10.08 & 106.1 \\
\hline $4 \mathrm{H}$ & 24 June & 0740 & $28.3-37.8$ & 9.5 & 10.04 & 105.7 \\
\hline $5 \mathrm{H}$ & 24 June & 0850 & $37.8-47.3$ & 9.5 & 9.32 & 98.1 \\
\hline $6 \mathrm{H}$ & 24 June & 1005 & $47.3-56.8$ & 9.5 & 10.02 & 105.5 \\
\hline $7 \mathrm{H}$ & 24 June & 1115 & $56.8-66.3$ & 9.5 & 9.88 & 104.0 \\
\hline $8 \mathrm{H}$ & 24 June & 1225 & $66.3-75.8$ & 9.5 & 9.99 & 105.0 \\
\hline $9 \mathrm{H}$ & 24 June & 1340 & $75.8-85.3$ & 9.5 & 9.93 & 104.0 \\
\hline $\begin{array}{l}10 \mathrm{H} \\
10 \mathrm{H}\end{array}$ & 24 June & 1455 & $85.3-94.8$ & 9.5 & 9.95 & $\begin{array}{l}105.0 \\
105.0\end{array}$ \\
\hline $11 \mathrm{H}$ & 24 June & 1550 & $94.8-104.3$ & 9.5 & 9.87 & 104.0 \\
\hline $12 \mathrm{H}$ & 24 June & 1640 & $104.3-113.8$ & 9.5 & 10.17 & 107.0 \\
\hline $13 \mathrm{H}$ & 24 June & 1740 & $113.8-123.3$ & 9.5 & 9.33 & 98.2 \\
\hline $14 \mathrm{H}$ & 24 June & 1835 & $123.3-130.0$ & $\begin{array}{l}6.7 \\
6.7\end{array}$ & $\begin{array}{l}6.35 \\
6.88\end{array}$ & $\begin{array}{r}90.2 \\
102.0\end{array}$ \\
\hline $15 \mathrm{X}$ & 24 June & 1930 & $130.0-132.7$ & 2.7 & 4.77 & 176.0 \\
\hline $\begin{array}{l}10 \mathrm{~A} \\
16 \mathrm{X}\end{array}$ & 24 June & 2150 & $132.7-142.3$ & 9.6 & 9.43 & 98.2 \\
\hline $17 \mathrm{X}$ & 24 June & 2255 & $142.3-151.9$ & 9.6 & 8.74 & 91.0 \\
\hline $18 \mathrm{X}$ & 25 June & 0055 & $151.9-161.6$ & 9.7 & 8.43 & 86.9 \\
\hline $\begin{array}{l}10 \mathrm{X} \\
19 \mathrm{X}\end{array}$ & 25 June & 0155 & $161.6-171.2$ & 9.6 & $\begin{array}{l}6.25 \\
6.25\end{array}$ & $\begin{array}{l}65.1 \\
65.1\end{array}$ \\
\hline $20 \mathrm{X}$ & 25 June & 0425 & $171.2-180.8$ & $\begin{array}{l}9.0 \\
9.6\end{array}$ & $\begin{array}{l}0.25 \\
8.96\end{array}$ & 93.3 \\
\hline $21 \mathrm{X}$ & 25 June & 0545 & $180.8-190.4$ & 9.6 & 9.75 & 101.0 \\
\hline $22 \mathrm{X}$ & 25 June & 0720 & $190.4-194.5$ & 4.1 & 2.47 & 60.2 \\
\hline Coring totals: & & & & 194.5 & 193.05 & 99.3 \\
\hline $\begin{array}{l}168-1024 \mathrm{~A}- \\
1 \mathrm{H}\end{array}$ & 25 June & 1410 & $0.0-9.2$ & 9.2 & 9.18 & 99.8 \\
\hline Coring totals: & & & & 9.2 & 9.18 & 99.8 \\
\hline \multicolumn{7}{|l|}{ 168-1024B- } \\
\hline $1 \mathrm{H}$ & 25 June & 1825 & $0.0-7.6$ & 7.6 & 7.59 & 99.8 \\
\hline $2 \mathrm{H}$ & 25 June & 1910 & $7.6-17.1$ & 9.5 & 9.87 & 104.0 \\
\hline $3 \mathrm{H}$ & 25 June & 2025 & $17.1-26.6$ & 9.5 & 9.54 & 100.0 \\
\hline $4 \mathrm{H}$ & 25 June & 2115 & $26.6-36.1$ & 9.5 & 9.56 & 100.0 \\
\hline $\begin{array}{l}4 \mathrm{H} \\
5 \mathrm{H}\end{array}$ & 25 June & 2215 & $36.1-45.6$ & 9.5 & $\begin{array}{l}9.50 \\
9.52\end{array}$ & 100.0 \\
\hline $6 \mathrm{H}$ & 25 June & 2305 & $45.6-55.1$ & 9.5 & 9.64 & 101.0 \\
\hline $7 \mathrm{H}$ & 26 June & 0010 & $55.1-64.6$ & 9.5 & 9.82 & 103.0 \\
\hline $8 \mathrm{H}$ & 26 June & 0050 & $64.6-74.1$ & 9.5 & 9.39 & 98.8 \\
\hline $9 \mathrm{H}$ & 26 June & 0150 & $74.1-83.6$ & 9.5 & 10.04 & 105.7 \\
\hline $10 \mathrm{H}$ & 26 June & 0240 & $83.6-93.1$ & 9.5 & 9.50 & 100.0 \\
\hline $\begin{array}{l}10 \mathrm{H} \\
11 \mathrm{H}\end{array}$ & 26 June & 0340 & $93.1-102.6$ & 9.5 & 9.72 & 102.0 \\
\hline $12 \mathrm{H}$ & 26 June & 0545 & $102.6-112.1$ & 9.5 & 9.58 & 101.0 \\
\hline $13 \mathrm{H}$ & 26 June & 0640 & $112.1-121.6$ & 9.5 & 9.54 & 100.0 \\
\hline $14 \mathrm{X}$ & 26 June & 0735 & $121.6-131.2$ & 9.6 & $\begin{array}{l}9.34 \\
9.73\end{array}$ & $\begin{array}{l}100.0 \\
101.0\end{array}$ \\
\hline $15 \mathrm{X}$ & 26 June & 0930 & $131.2-140.8$ & 9.6 & 9.66 & 100.0 \\
\hline $\begin{array}{l}10 \mathrm{~A} \\
16 \mathrm{X}\end{array}$ & 26 June & 1015 & $140.8-150.4$ & 9.6 & 9.68 & $\begin{array}{l}101.0 \\
101.0\end{array}$ \\
\hline $\begin{array}{l}10 \mathrm{X} \\
17 \mathrm{X}\end{array}$ & 26 June & 1110 & $150.4-160.0$ & $\begin{array}{l}9.0 \\
9.6\end{array}$ & $\begin{array}{l}9.00 \\
9.72\end{array}$ & 101.0 \\
\hline $18 \mathrm{X}$ & 26 June & 1320 & $160.0-169.6$ & 9.6 & 8.01 & 83.4 \\
\hline \multicolumn{4}{|l|}{ Coring totals: } & 169.6 & 170.11 & 100.3 \\
\hline $\begin{array}{l}168-1024 \mathrm{C}- \\
1 \mathrm{R}\end{array}$ & 31 July & 1200 & $173.7-175.7$ & 2.0 & 0.12 & 6.0 \\
\hline \multicolumn{4}{|l|}{ Coring totals: } & 2.0 & 0.12 & 6.0 \\
\hline \multicolumn{2}{|l|}{$168-1025 \mathrm{~A}-$} & 2150 & $0.0-6.3$ & 6.3 & 6.34 & 100.0 \\
\hline Coring totals: & & & & 6.3 & 6.34 & 100.0 \\
\hline \multicolumn{7}{|l|}{ 168-1025B- } \\
\hline $1 \mathrm{H}$ & 27 June & 0420 & $0.0-5.0$ & 5.0 & 4.95 & 99.0 \\
\hline $2 \mathrm{H}$ & 27 June & $\begin{array}{l}0525 \\
0620\end{array}$ & $\begin{array}{r}5.0-14.5 \\
14.5-24.0\end{array}$ & 9.5 & $\begin{array}{r}9.85 \\
1000\end{array}$ & $\begin{array}{l}103.0 \\
1052\end{array}$ \\
\hline $\begin{array}{l}3 \mathrm{H} \\
4 \mathrm{H}\end{array}$ & 27 June & 0715 & $\begin{array}{l}14.5-24.0 \\
24.0-33.5\end{array}$ & $\begin{array}{l}9.3 \\
9.5\end{array}$ & $\begin{array}{l}10.00 \\
10.06\end{array}$ & $\begin{array}{l}105.2 \\
105.9\end{array}$ \\
\hline $5 \mathrm{H}$ & 27 June & 0810 & $33.5-43.0$ & 9.5 & 10.07 & 106.0 \\
\hline $6 \mathrm{H}$ & 27 June & 0900 & $43.0-52.5$ & 9.5 & 9.59 & 101.0 \\
\hline $7 \mathrm{H}$ & 27 June & 0950 & $52.5-62.0$ & 9.5 & 9.87 & 104.0 \\
\hline $8 \mathrm{H}$ & 27 June & 1055 & $62.0-71.5$ & 9.5 & 10.01 & 105.3 \\
\hline $9 \mathrm{X}$ & 27 June & 1145 & $71.5-81.1$ & 9.6 & 0.40 & 4.2 \\
\hline $10 \mathrm{X}$ & 27 June & 1330 & $81.1-90.7$ & 9.6 & 9.36 & 97.5 \\
\hline $11 \mathrm{X}$ & 27 June & 1445 & $90.7-99.5$ & 9.6 & 6.89 & 71.8 \\
\hline Coring totals: & & & & 100.3 & 91.05 & 90.8 \\
\hline \multicolumn{7}{|l|}{$168-1025 \mathrm{C}-$} \\
\hline $1 \mathrm{R}$ & 27 July & 2225 & $106.1-112.3$ & 6.2 & 3.30 & 53.2 \\
\hline $2 \mathrm{R}$ & 28 July & 0145 & $112.3-118.4$ & 6.1 & 4.40 & 72.1 \\
\hline $3 R$ & 28 July & 0640 & $118.4-128.0$ & 9.6 & 0.96 & 10.0 \\
\hline $4 \mathrm{R}$ & 28 July & 0935 & $128.0-137.6$ & 9.6 & 3.34 & 34.8 \\
\hline $5 \mathrm{R}$ & 28 July & 1530 & $137.6-147.2$ & 9.6 & 3.16 & 32.9 \\
\hline \multicolumn{4}{|l|}{ Coring totals: } & 41.1 & 15.16 & 36.9 \\
\hline
\end{tabular}

Notes: UTC $=$ Universal Time Coordinated. For each site, an expanded coring summary table that includes lengths and depths of sections and sampling comments is included on CD-ROM (back pocket). the return trip, fill was tagged $16 \mathrm{~m}$ off bottom. This was easily circulated away until firm fill was reached $7.6 \mathrm{~m}$ above the original hole TD. An additional $2.0 \mathrm{~m}$ was washed away, and then a 40-bbl sepiolite mud sweep was pumped. After a short trip, fill was still evident $10 \mathrm{~m}$ off bottom. Using the top drive, the fill was circulated out until hard fill was reached $3.0 \mathrm{~m}$ above TD. At this point another 50-bbl sepiolite pill was circulated, followed by a 50-bbl seawater spacer and $140 \mathrm{bbl}$ of sepiolite mud to displace the hole. The drilling assembly was recovered, and preparations began for making up and running the $103 / 4$-in surface casing string. It took only $3.5 \mathrm{hr}$ to make up 12 joints of K-55, $40.5 \mathrm{lb} / \mathrm{ft}$ surface casing, including making up the casing hanger, and Dril-Quip running tool. After the casing was run to the seafloor, the top drive and TIW cementing manifold were picked up, and within 45 min another reentry was made. The casing hanger was landed, and latch-in was confirmed with 15,000 lb of overpull. A total of 61.7 bbl of 15.8-ppg class $\mathrm{G}$ neat cement was mixed and displaced downhole; however, there was no indication that the dart landed or that the wiper plug released properly. Although the Dril-Quip running tool appeared to rotate downhole the requisite number of turns ( 3.5 to the right), the tool would not come free from the hanger. After waiting nearly $6 \mathrm{hr}$ for the cement to partially harden, the pipe was merely raised, and the tool came free. Apparently, the tool did rotate properly because the buoyancy effect of the casing in the cement put the release ring in compression, preventing the ring from moving inward to release. A higher overpull applied earlier probably would have released the tool at that time. The drill string was tripped back to the drillship, ending the present round of operations at Hole 1024C. This hole was to be reoccupied again later for rotary core barrel (RCB) coring in basement, packer experiments, and CORK installation operations.

\section{Site $\mathbf{1 0 2 5}$}

\section{Return to Hole $1025 C$}

The drillship was offset in DP mode back to Hole 1025C (HT-4A) while recovering the casing-running BHA from Hole 1024C (HT3A). The 103/4-in Dril-Quip running tool was de-torqued at the rig floor, and an RCB-coring BHA with mechanical drilling jars was made up and run in the hole. The reentry cone was reentered 15 min after reaching the seafloor, and the drilling assembly was run to bottom. The top of the cement was tagged at a depth of $2706.0 \mathrm{~m}$, or 88.8 mbsf. Just under $6 \mathrm{hr}$ was required to drill out the cement in the casing, the casing shoe, and the cement beneath the shoe. The center bit was recovered on the wireline, and RCB coring operations commenced. Continuous RCB coring in igneous basement progressed through Core 168-1025C-5R to a total depth of $2764.4 \mathrm{~m}$ (147.2 mbsf) with moderate recovery. The rate of penetration varied dramatically as various units within basement were penetrated. Drilling was slow in massive layers; some zones were encountered where the bottom seemed to fall out, and rapid penetration was achieved for several meters. Hole conditions were generally good although some pipe sticking and hole trouble became apparent after advancing Core $4 \mathrm{R}$ to a depth of $2754.8 \mathrm{~m}$ (137.6 mbsf). The tight spots were worked repeatedly with the drill pipe, and 30-bbl sepiolite mud sweeps were pumped after Cores 4R and 5R. A wiper trip to 108.9 mbsf was made, and on the return trip ledges in the hole were identified at $2725.0 \mathrm{~m}$ (107.8 mbsf) and $2746.0 \mathrm{~m}$ (128.8 mbsf). Fill was tagged at 2749.0 $\mathrm{m}, 15.4 \mathrm{~m}$ off bottom. Another 30-bbl sepiolite mud sweep was pumped while washing back to hole TD. On the next short trip, fill was tagged at $2756.0 \mathrm{~m}$, or $8.4 \mathrm{~m}$ off bottom. The fill was circulated out one final time, and $30 \mathrm{bbl}$ of sepiolite mud sweep was pumped. The drill string was recovered, and preparations for deployment of the TAM International packer were initiated. Once reentry had been accomplished with the TAM packer (30 min), the BHA was run to the packer setting point inside the second casing joint from the bottom. 
A wireline depth check of the hole TD was made before packer operations began to determine the amount of hole available for thermistor emplacement. The Davis/Villinger Temperature Probe (DVTP) was deployed, and measurements were taken at $5.0-\mathrm{m}$ intervals from the 103/4-in casing shoe to hole TD during the first depth check wireline run. A temperature profile of the hole was thus obtained. Hole depth was measured at $2754.0 \mathrm{~m}$ (136.8 mbsf), or $35.8 \mathrm{~m}$ into basement. Several unsuccessful attempts were made to set the TAM packer. Multiple wireline runs were made with the first setting go-devil, and another go-devil was used as well. Nothing wrong was identified with either go-devil, yet the packer would not inflate. Another depth check of the hole was made via wireline while meeting with rig personnel, the co-chiefs, and the packer scientists. It was decided that further attempted packer operations would be abandoned in lieu of proceeding with the setting of the CORK assembly. Two compelling factors affected the decision. The current weather window was ideal for CORK operations, and the second wireline depth check indicated another possible loss of $2.0 \mathrm{~m}$ of hole (TD of $2752.0 \mathrm{~m}$ ). The measurements were made about $6 \mathrm{hr}$ apart and could have been partially influenced by the $2.0-\mathrm{m}$ tide that had been apparent for most of the leg; however, there continued to be concern about possible continued loss of available hole for thermistor deployment. The drill string was tripped back to the rig floor, and preparations for setting the second CORK of the leg were begun.

Upon inspection, nothing was found mechanically wrong with the packer assembly. A new control sleeve had been installed after the last deployment. The new sleeve apparently fit somewhat tighter than the old worn one. With little or no weight below the packer, the control sleeve apparently stopped approximately 1 in from being fully extended in the open position. If the control sleeve is not fully open, inflation cannot take place, and setting becomes impossible.

Three obsolete $91 / 2$-in drill collars were used for CORK stinger material. These were too large for the iron roughneck to handle, so conventional rig tongs were used for assembly. Rig-up and deployment of the CORK assembly went well with no major problems. The CORK was tripped to the seafloor, and reentry was made within 10 min. The stinger was positioned inside the reentry cone without landing the CORK, and the thermistor string/osmotic pump assembly was deployed down the drill string. As with the first CORK deployment at Site 1027, the dual-grip lifting technique was used. The system is less than ideal but worked well enough for the relatively short thermistor string. Within an hour, the thermistor was deployed inside the drill pipe and ready for running to bottom. A final electronic check was made on the data logger located at the top of the thermistor string, and the assembly was run to bottom on the wireline using the data-logger setting tool. Several landing attempts were made to seat the seals before the release tool pressured up. The shear pin in the overshot apparently sheared during the pressurization phase because no overpull was experienced when the wireline was recovered. The CORK setting go-devil was deployed after pulling the mousehole and picking up two additional joints of drill pipe. The CORK was landed and the setting go-devil pressured up. Latch engagement was verified with drill string overpull, and the CORK platform was deployed. The VIT camera was deployed to verify that the installation was complete. The CORK running tool was released, and the camera was recovered. The drill string was tripped back to the rig floor, and the positioning beacon was recovered. During the trip out, the ship was offset in DP mode back to Hole 1024C. Operations at the hole ended once all tools were recovered aboard ship.

\section{Site 1024}

\section{Return to Hole $1024 C$}

An RCB BHA was made up and run to the seafloor. The VIT camera was deployed during the pipe trip, and a routine reentry was made within $15 \mathrm{~min}$. The bit contacted the top of the cement column at a depth of $2777.2 \mathrm{~m}$, or $153.9 \mathrm{mbsf}$. The cement and float shoe were drilled out in short order, and the center bit was recovered. Note that on this hole the cementing dart and wiper plug did not release. The dart was recovered, but it was not known whether the casing wiper plug had fallen into the reentry cone or outside the hole. The bit broke through to the rathole after only $1.5 \mathrm{hr}$. Once RCB coring was initiated, the bit advanced only $2.0 \mathrm{~m}$ before tight hole conditions and torquing led to early retrieval of the core barrel. Recovery was minimal $(0.12 \mathrm{~m})$, but included in the core liner was a section of the float shoe, including the entire float valve assembly. Apparently the inner portion of the float shoe had broken free during the center-bit drilling phase and fallen to the bottom of the rathole. This allowed the core barrel to swallow the float valve perfectly during the first coring attempt. The next $4 \mathrm{hr}$ was spent fighting stuck pipe and hole trouble until the decision was made to abandon attempts at further penetration. Earlier in the leg, while drilling the 143/4-in hole for the 103/4-in surface casing, drilling was also stopped because of bad hole conditions and stuck pipe. The hole was abandoned at that time $22.0 \mathrm{~m}$ into basement and was left with $3.0 \mathrm{~m}$ of hard fill on bottom. Coring operations on this bit run were halted after one core and a TD of 2797.0 $\mathrm{m}$ (173.7 mbsf). The depth of the open hole remained the same at $2794.0 \mathrm{~m}$ (169.7 mbsf). The bit was pulled up inside the 103/4-in casing shoe, and the second core barrel was recovered. This was not considered a core because no advance was made and no core recovery was obtained. After tripping the drill string and before making up the TAM packer BHA, the mechanical drilling jars were tested at the rig floor. The jars were not only locked up because of debris; they also failed to hold circulation pressure. This undoubtedly contributed to the hole cleaning problems during the attempted coring because the full circulation was obviously not getting to the bit. Because identical drilling problems were encountered while drilling the 14\%3-in hole without the drilling jars in the BHA, the drilling jars were not believed to be the sole reason for the failure to advance the hole. The jars were cleaned up and prepared to be shipped back for refurbishment. A reentry cleanout bit and a $10-\mathrm{ft}$ drill collar pup joint was made up directly below the packer to aid in keeping the control sleeve fully extended. The packer BHA was run to bottom, but before reentry a wiper plug was pumped down the drill string. After another routine 15 -min reentry, the circulation system was pressure tested, and the pipe was lowered to a packer setting depth of $2775.3 \mathrm{~m}$ (152.0 mbsf). The DVTP was run to bottom on the wireline for a preliminary depth check of the hole and to obtain a bottom-hole temperature. There was no problem setting the packer in this hole, and the packer testing went exceptionally well. After two successful injection and flow tests were completed, the packer was released, and a final depth check was made with the wireline. Usable hole depth was confirmed as unchanged at $2794.0 \mathrm{~m}$, and this depth was used to calculate the final thermistor length for the hole. The pipe was retrieved back to the ship, and preparations began for deploying the third CORK of Leg 168. The CORK deployment again went exceptionally well. The last three of the obsolete $91 / 2$-in drill collars were made up as the CORK stinger and hung off. The CORK body was positioned in the skate, and the running tool was made up. The CORK assembly was made up to the CORK stinger and lowered so that the final connection could be made with the CORK setting hose. As on earlier deployments, the hole number was painted on the CORK body identifying the installation for later visits by submersible or remotely operated vehicle (ROV). Once the safety blocks and packing protectors were removed, the CORK was ready for deployment. The tool was run to bottom, and within $15 \mathrm{~min}$ a reentry was made. Deployment of the osmotic sampler, thermistor string, and data logger proceeded without incident. A final electronic check on the data logger was conducted just before the running tool was installed. The thermistor string was run to bottom, and the data logger landed/latched into the CORK. A wireline overpull before shearing the weakened overshot pin in the running tool confirmed data logger latch-in. After retrieving the wire- 
line, the CORK setting tool was deployed and pressured up. After bleeding off the pressure, the drill pipe was picked up. A 10,000-lb overpull confirmed that the CORK was now latched in place. The VIT frame was deployed, and the camera was used to witness the release from the CORK installation. The setting go-devil was retrieved, and the drill string was tripped back to the ship while the positioning beacon was released and recovered. Once the ship was secured, the hole was officially ended, and the transit to Hole 1026C was begun.

\section{LITHOSTRATIGRAPHY}

\section{Stratigraphic Units}

The sedimentary succession along the Hydrothermal Transition Transect includes three lithostratigraphic units and subunits above igneous basement (Fig. 5). Composite Unit I is Quaternary in age and comprises a background of hemipelagic mud (clayey silt to silty clay) with hundreds of turbidite interbeds that range in texture from medium-fine sand to sandy silt and silt. Subunit IA contains discrete sand beds, whereas Subunit IB is limited to silt turbidites. The boundary between Subunits IA and IB occurs at approximately $162 \mathrm{mbsf}$ in Hole 1023A, 121 mbsf in Hole 1024B, and 70 mbsf in Hole 1025B. The base of Subunit IB coincides with the base of the deepest silt turbidite below seafloor. This unit boundary occurs at depths of approximately 190, 150, and $88 \mathrm{mbsf}$ in Holes 1023A, 1024B, and 1025B, respectively (Table 2). Most hemipelagic mud deposits within Unit I are fairly homogeneous, but there are scattered clay-rich color bands, silt laminae, zones of bioturbation, and increases in biogenic constituents, especially calcareous nannofossils. Turbidites are characterized by sharp to erosional bases, normal size grading, plane-parallel laminae, and gradational tops. Some beds also display ripple crosslaminae, convolute laminae, or wavy laminae. Because of bioturbation and erosion beneath successive turbidity currents, it is difficult to separate the muddy tops of graded beds from hemipelagic mud intervals using only visual criteria. Our operational boundaries for these beds (see Table 3 on CD-ROM, back pocket) are based on the disappearance of diagnostic sedimentary structures, especially planeparallel laminae. In general, turbidite thicknesses increase as grain size coarsens. Beds of silt and sandy silt typically measure less than $10 \mathrm{~cm}$ in thickness, whereas sand beds reach maximum thicknesses of $50-100 \mathrm{~cm}$. Internal sedimentary structures near the bases of thicker sand deposits typically are destroyed by the APC coring process and the flow of unconsolidated sand in the core liners. We classify most of the relatively thin beds, however, as base-missing Bouma sequences.

Turbidite stratigraphy differs at each of the Hydrothermal Transition sites, despite their close proximity (Fig. 6). The most obvious difference is related to the total thickness of Unit I, which expands from approximately $88 \mathrm{~m}$ at Site 1025 to $150 \mathrm{~m}$ at Site 1024 to 190 $\mathrm{m}$ at Site 1023. Each turbidite succession displays a crude overall trend of upward coarsening and upward thickening, as measured from the base of Unit I. Each succession also contains several smaller scale upward-thickening cycles and intervals with clusters of thicker turbidites (Fig. 6). We were unable to recognize marker beds, however, so intersite correlations among the turbidite clusters remain questionable. Depositional patterns appear to be more complicated than just condensation and expansion of layer thicknesses in response to basement topography. The total number of turbidites measured at each site, for example, increases from 257 for Hole 1025B to 295 for Hole $1024 \mathrm{~B}$ to 386 for Hole 1023A (Table 3 on CD-ROM, back pocket). Thus, the absolute number of depositional events associated with turbidity currents increased significantly from east to west.

Unit II is Quaternary in age and characterized by hemipelagic mud deposits (silty clay to clayey silt) with highly variable admixtures of siliciclastic and biogenic constituents. Increases in the content of calcareous nannofossils are erratic and generally coincide with a subtle lightening of color. Sediments within Unit II also contain local pyrite nodules and darker colored clay-rich bands. The thickness of Unit II ranges from $2.6 \mathrm{~m}$ in Hole 1023A to $9.5 \mathrm{~m}$ in Hole $1025 \mathrm{~B}$ to $18.1 \mathrm{~m}$ in Hole 1024B. The first recovery of basalt defines the base of Unit II in each hole (Table 2).

\section{Sedimentary Petrology}

\section{Carbonate Content}

Figure 7 illustrates variations in the content of calcium carbonate for samples from Sites 1023, 1024, and 1025, as measured by coulometric analyses (see Table 17 on CD-ROM, back pocket). Strata from Unit I contain low weight percentages of calcium carbonate, with average values of 3.8 and $3.2 \mathrm{wt} \%$ for Holes 1023A and 1024B, respectively. Values for Hole 1025B samples are slightly higher, with an average of $5.1 \mathrm{wt} \%$. Carbonate content increases sporadically at all three sites near the base of Subunit IB and within Unit II. In general, these mixed carbonate-siliciclastic sediments are lighter in color than surrounding clayey silts, and nannofossils provide the main source of carbonate. Average amounts of carbonate within Unit II samples range from $8.8 \mathrm{wt} \%$ (Hole 1023A) to $17.8 \mathrm{wt} \%$ (Hole 1024B) to 25.0 $\mathrm{wt} \%$ (Hole 1025B). The highest value recorded is $63.4 \mathrm{wt} \%$.

\section{Mineralogy}

Figure 8 shows examples of bulk-powder X-ray diffractograms used to determine relative abundances of major mineral phases (see Tables 4 and 5 on CD-ROM, back pocket, for lists of data). Subtle mineralogic variations occur within and among Sites 1023, 1024, and 1025 , and most of these variations appear related more to differences in grain size than to detrital provenance. For example, the ratio of total phyllosilicates (muscovite + chlorite + illite + smectite) to total feldspar (plagioclase $+\mathrm{K}$-feldspar) changes consistently as a function of lithology (Fig. 9). Predictably, the phyllosilicate content increases in fine-grained sediment. Relative abundances of most major phases display considerable scatter in the upper turbidite-rich intervals of each hole (Fig. 10), where samples were obtained from interbeds of both sand or silt and hemipelagic mud. The influence of hydrothermal or diagenetic alteration on bulk mineralogy appears to be negligible within the Hydrothermal Transition Transect area.

Unit I is characterized by a detrital assemblage of quartz, plagioclase, K-feldspar, muscovite + illite, chlorite, and smectite as major phases. Minor amounts of amphibole, biotite, pyrite, opaque minerals, and rock fragments also are present (see smear-slide reports on CD-ROM, back pocket). Siliceous and calcareous biogenic components are present in minor to trace amounts in the fine-grained sediments. Traces of pyroxene and hematite appear consistently in smear slides. Other accessory minerals include zircon, apatite, and epidote.

The relative abundance of quartz generally ranges from 20 to 35 $\mathrm{wt} \%$ of the bulk mineralogy, regardless of sediment texture (Fig. 10). Quartz in the sand-sized fraction is subrounded to angular, and most grains are less than $150 \mu \mathrm{m}$ in diameter. There is a subtle but systematic decrease in quartz content with depth. This trend probably coincides with a gradual decrease in mean grain size. Conversely, the content of total feldspar in the hemipelagic muds increases systematically with depth (Fig. 10). This change in the quartz-feldspar ratio should be expected as mean grain size becomes smaller because feldspar tends to fracture readily along cleavage and twinning surfaces. Total feldspar content also increases from about 10-30 wt $\%$ in clayey silt to 35-65 wt\% in silt and sand deposits. Sand-sized feldspar grains are similar in dimension to those of quartz, but their grain shapes tend to be more angular. Total phyllosilicate content increases from approximately $10-25 \mathrm{wt} \%$ in sandy deposits to $30-50 \mathrm{wt} \%$ in clayey silt (Fig. 9). Most phyllosilicates in the sand beds probably reside in aphanitic rock fragments and primary clay-sized matrix. The most abundant clay mineral is smectite, which evidently makes up 10-25 
Figure 5. Stratigraphic summary for sites along the Hydrothermal Transition Transect. Bed thicknesses are not shown to scale. Sand turbidites $=$ white; silt turbidites $=$ black

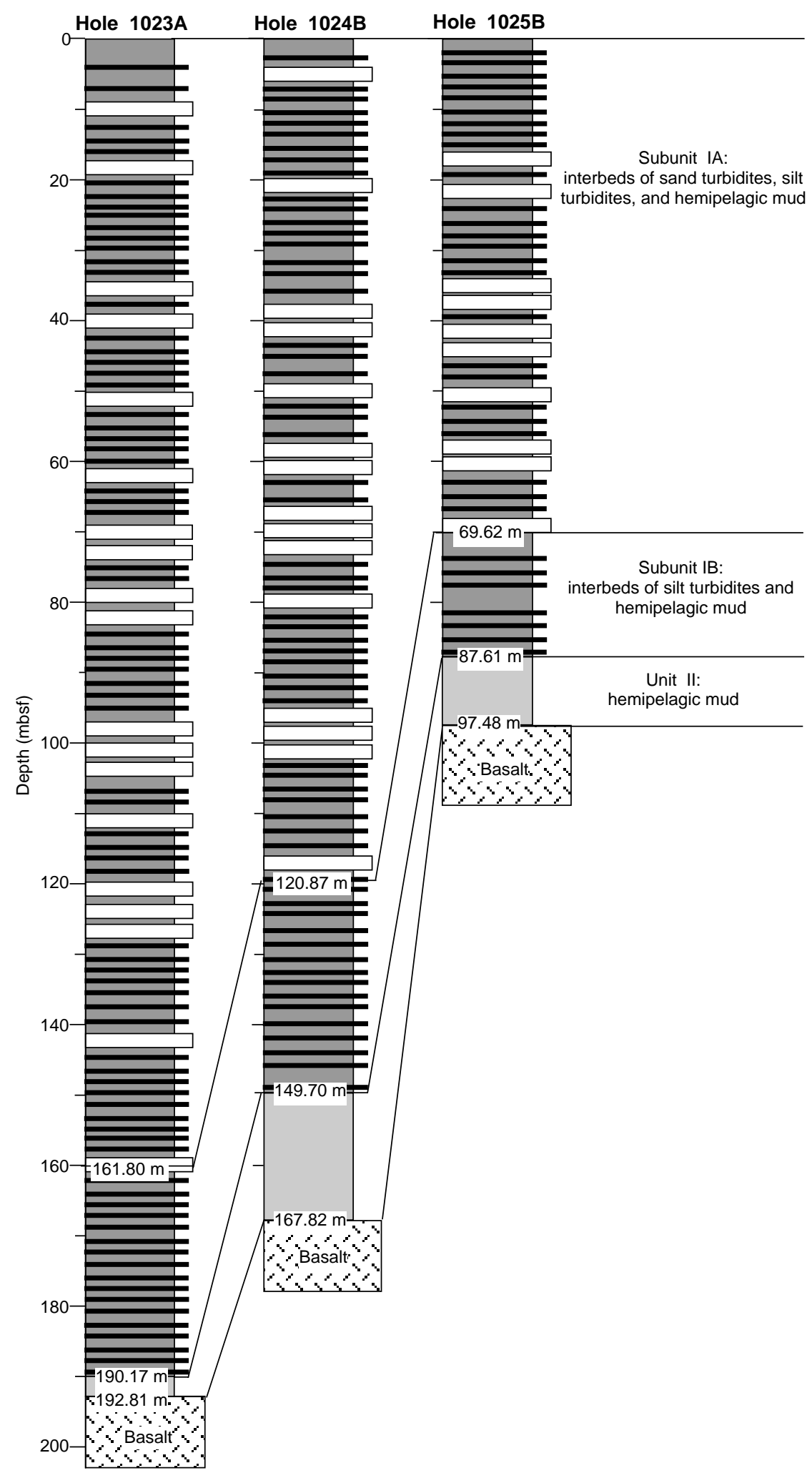

wt $\%$ of a typical clayey silt (Table 5 on CD-ROM, back pocket). The content of smectite, however, is particularly difficult to quantify accurately with analyses of random, air-dried bulk powders. Relative weight percentages of illite + muscovite and chlorite are fairly uniform; most values are between 5 and $15 \mathrm{wt} \%$ (Table 5).
Deposits of Unit II include variable admixtures of siliciclastic mud and calcareous ooze. Nannofossil-rich sediments contain abundant calcite and local concentrations of smectite (as much as $25 \%$ ). Smear slides show some evidence for dissolution of the nannofossils. Siliciclastic-rich deposits of Unit II contain the same overall detrital 
Table 2. Summary of lithostratigraphic units within the Hydrothermal Transition Transect area.

\begin{tabular}{|c|c|c|c|c|c|}
\hline Unit & Age & Lithologic character & Hole & Interval & $\begin{array}{l}\text { Thickness } \\
\text { (m) }\end{array}$ \\
\hline IA & Quaternary & Sand turbidites, silt turbidites, and hemipelagic mud & $\begin{array}{l}1023 \mathrm{~A} \\
1024 \mathrm{~B} \\
1025 \mathrm{~B}\end{array}$ & $\begin{array}{l}1 \mathrm{H}-1,0 \mathrm{~cm} \text {, to } 19 \mathrm{X}-1,20 \mathrm{~cm} \\
1 \mathrm{H}-1,0 \mathrm{~cm} \text {, to } 13 \mathrm{H}-6,127 \mathrm{~cm} \\
1 \mathrm{H}-1,0 \mathrm{~cm} \text {, to } 8 \mathrm{H}-6,12 \mathrm{~cm}\end{array}$ & $\begin{array}{r}161.80 \\
120.87 \\
69.62\end{array}$ \\
\hline IB & Quaternary & Silt turbidites, hemipelagic mud, and carbonate-rich mud near base & $\begin{array}{l}1023 \mathrm{~A} \\
1024 \mathrm{~B} \\
1025 \mathrm{~B}\end{array}$ & $\begin{array}{l}19 \mathrm{X}-1,20 \mathrm{~cm} \text {, to } 21 \mathrm{X}-7,37 \mathrm{~cm} \\
13 \mathrm{H}-6,127 \mathrm{~cm} \text {, to } 16 \mathrm{X}-6,140 \mathrm{~cm} \\
8 \mathrm{H}-6,12 \mathrm{~cm} \text {, to } 10 \mathrm{X}-5,51 \mathrm{~cm}\end{array}$ & $\begin{array}{l}28.37 \\
28.83 \\
17.99\end{array}$ \\
\hline II & Quaternary & Hemipelagic mud, carbonate-rich mud & $\begin{array}{l}1023 \mathrm{~A} \\
1024 \mathrm{~B} \\
1025 \mathrm{~B}\end{array}$ & $\begin{array}{l}21 \mathrm{X}-7,37 \mathrm{~cm} \text {, to } 22 \mathrm{X}-\mathrm{CC}, 35 \mathrm{~cm} \\
16 \mathrm{X}-6,140 \mathrm{~cm} \text {, to } 18 \mathrm{X}-\mathrm{CC}, 9 \mathrm{~cm} \\
10 \mathrm{X}-5,51 \mathrm{~cm} \text {, to } 11 \mathrm{X}-5,40 \mathrm{~cm}\end{array}$ & $\begin{array}{l}2.64 \\
8.12 \\
9.49\end{array}$ \\
\hline
\end{tabular}

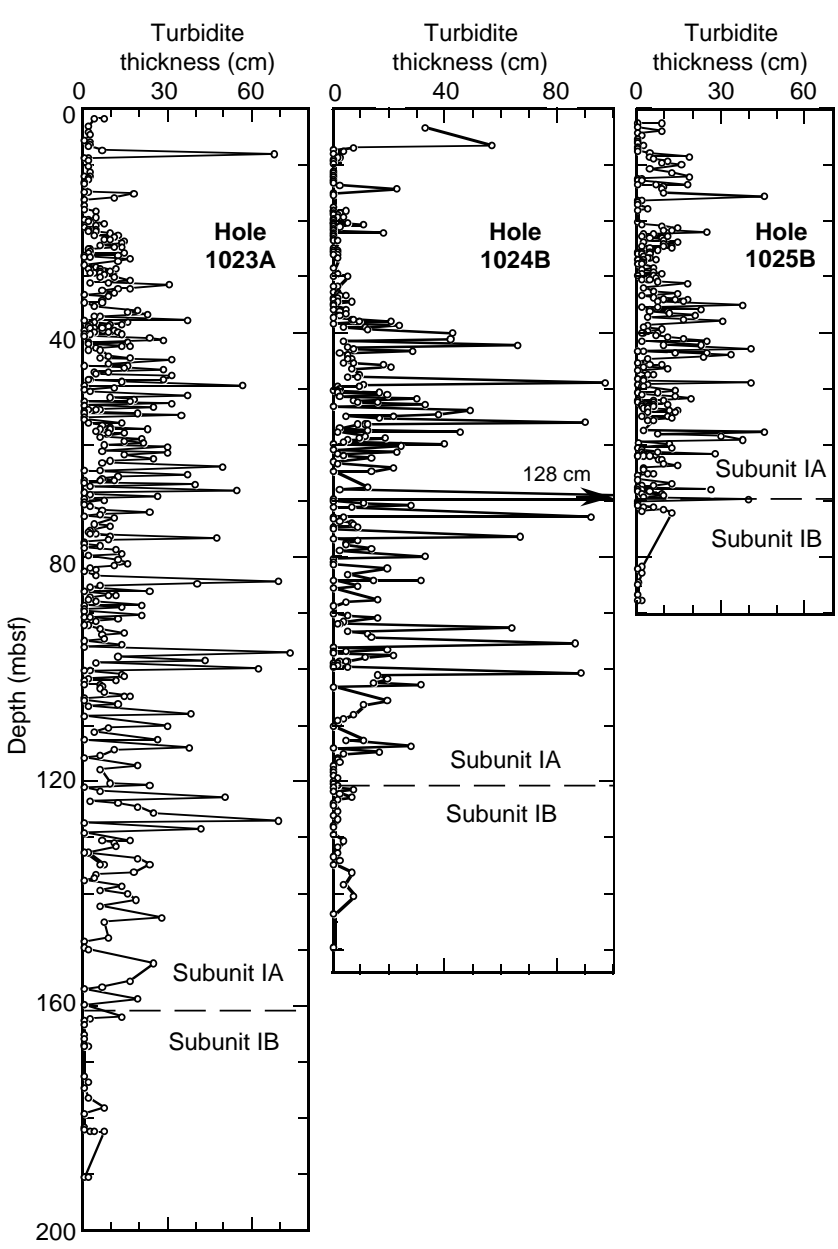

Figure 6. Depth distribution and thickness of sand and silt turbidites along the Hydrothermal Transition Transect.

assemblage as the hemipelagic muds of Unit I (Fig. 10). Amphibole, hematite, and opaque minerals are present in trace amounts. Siliceous biogenic debris includes diatoms, radiolarians, and sponge spicules.

\section{BASEMENT LITHOLOGY, PETROLOGY, GEOCHEMISTRY, AND ALTERATION}

\section{Lithologic Units}

Within the Hydrothermal Transition Transect, basement was recovered from Holes 1023A, 1024B, 1024C, 1025B, and 1025C. All

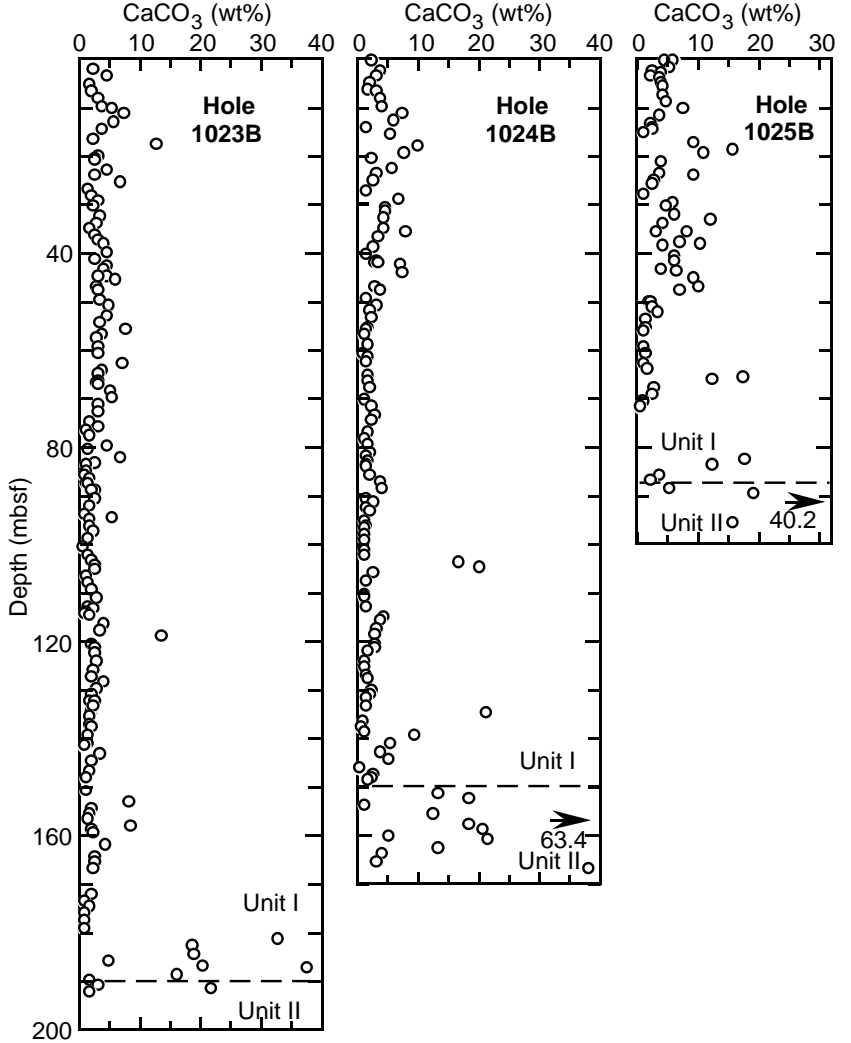

Figure 7. Contents of calcium carbonate along the Hydrothermal Transition Transect, as measured by coulometric analyses.

of the basement rocks consisted predominantly of aphyric plagioclase \pm olivine \pm pyroxene basalt; minor occurrences of sparsely phyric plagioclase \pm olivine \pm pyroxene basalt were also recovered from Holes 1023A and 1025B. Although lithologically similar, variations in structure occurred among the holes, with all cores from Holes $1023 \mathrm{~A}, 1024 \mathrm{~B}, 1024 \mathrm{C}$, and 1025B containing pillow basalt fragments and cores from Hole $1025 \mathrm{C}$ consisting of massive basalt flows (Fig. 11). Because the lithologic units were designated on the basis of changes in mineralogy, rock texture, and grain size, only one lithologic unit was defined within the Hydrothermal Transition sites (i.e., Unit 1; Table 6). Subunits (denoted by unit numbers and lowercase letters; e.g., 1a, 1f, etc.) within Holes 1024B, 1024C, 1025B, and $1025 \mathrm{C}$ were based on the presence of chilled margins within the rock sequence, as well as subtle but abrupt changes in the aphanitic grain size from microcrystalline to cryptocrystalline; this allowed individual cooling units to be recognized and logged. The massive basalt flows were subsequently classified as massive ferrobasalts, based on 

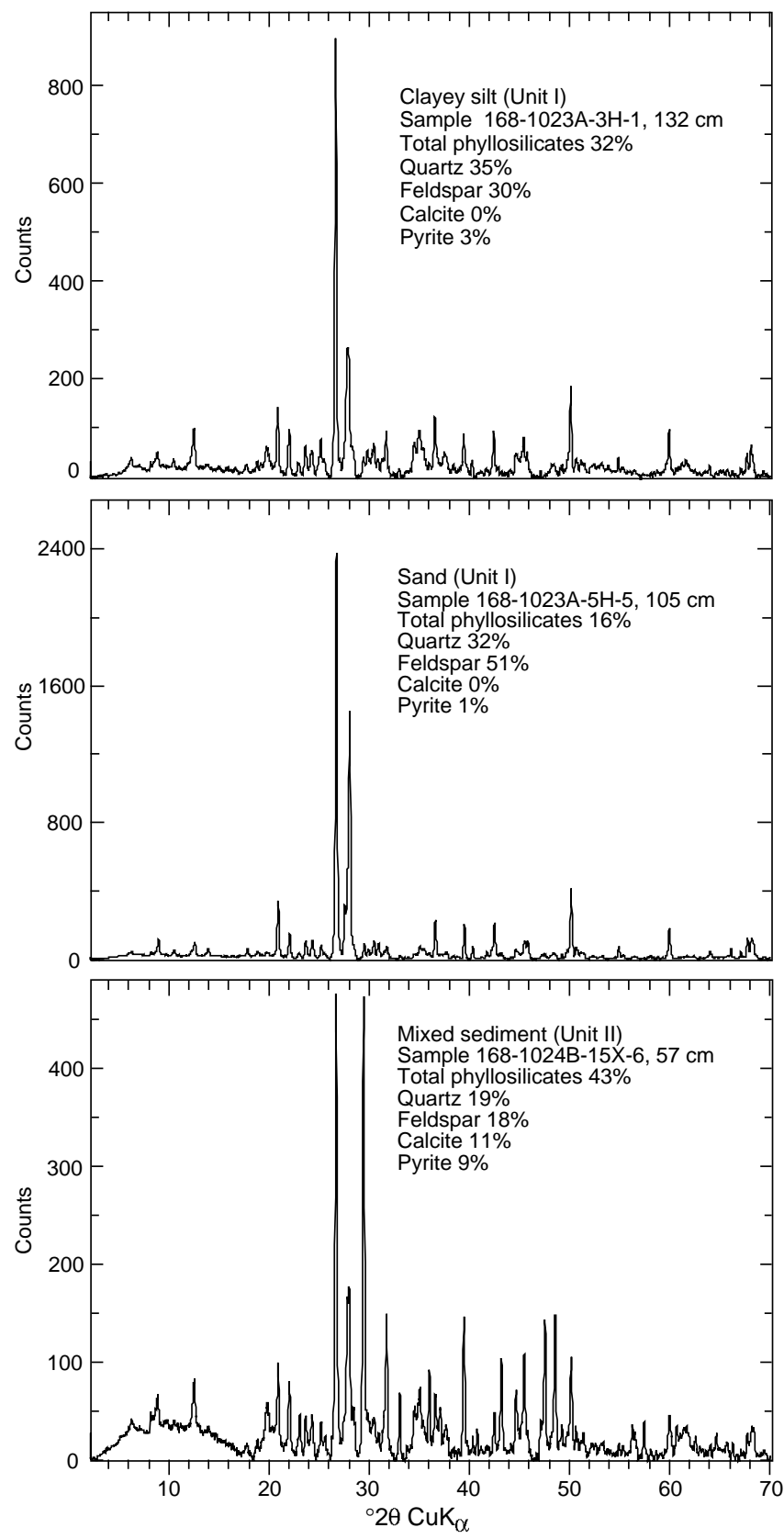

Figure 8. Examples of bulk-powder X-ray diffractograms showing differences in relative abundance of major mineral phases within common lithologies of sites along the Hydrothermal Transition Transect.

whole-rock geochemistry (see "Igneous Geochemistry" subsection, below).

\section{Pillow Basalts}

The majority of pillow basalts from Holes 1023A, 1024B, 1024C, and $1025 \mathrm{~B}$ are aphyric, containing from $\leq 1 \%$ to a trace amount of plagioclase \pm olivine \pm pyroxene phenocrysts. These are set within a glassy to microcrystalline groundmass containing microlaths to microlites of plagioclase and/or olivine, pyroxene, opaque oxides, and opaque sulfides. The texture of the aphyric pillow basalts varies within and between cores, from glassy to hypohyaline and hypocrys-

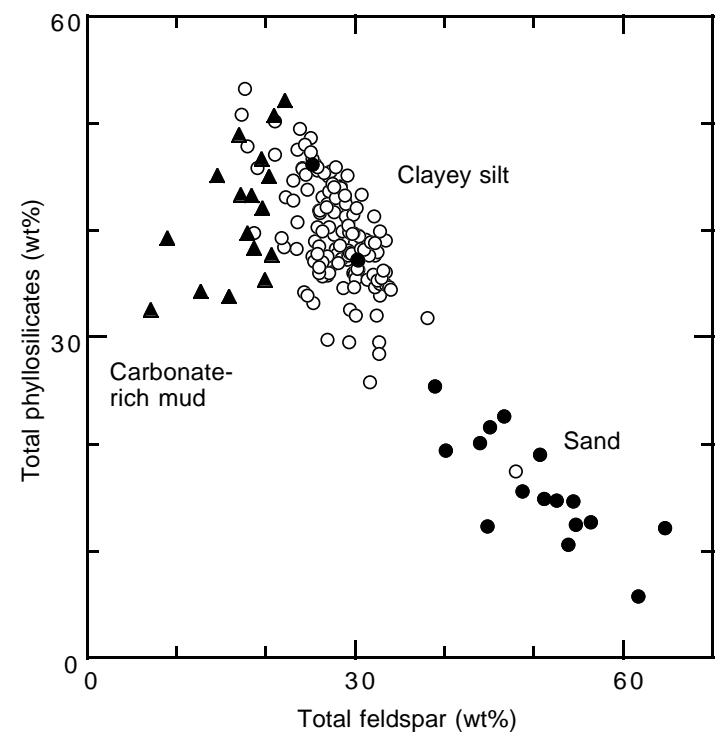

Figure 9. Relative weight percentage of total phyllosilicate minerals (smectite + chlorite + illite + muscovite) vs. total feldspar (plagioclase + K-feldspar), based on X-ray diffraction analyses of bulk powders. Note obvious sizedependent differences between hemipelagic mud samples (open circles), turbidite sand samples (solid circles), and carbonate-rich mud samples (triangles).

talline, with the mesostasis exhibiting a dominantly sheaf-spherulitic texture, whereas the microlites form an intersertal texture.

At the base of Sections 168-1023A-22X-CC and 1025B-11X-CC, two of the pillow basalt clasts are sparsely to moderately phyric, containing $2.5 \%-5 \%$ plagioclase, olivine and/or pyroxene phenocrysts. Although more phyric than the typical aphyric pillow basalts, these rocks are characterized by the same groundmass mineralogy, grain size, and rock texture as the pillow basalts. However, because they are rare, these fragments have been incorporated into the same subunit as the aphyric basalts (i.e., Subunit 1a; Table 6). All basalts (aphyric and sparsely to moderately phyric) are sparsely vesicular and contain round to ovoid gas $(\leq 1.6 \%)$ vesicles.

\section{Massive Ferrobasalts}

The aphyric basalts from Hole $1025 \mathrm{C}$ have a massive structure; it is therefore postulated that they originated from a massive flow sequence, and they are recognized as distinct subunits $(1 \mathrm{~b}-\mathrm{i})$ from the aphyric pillow basalts. (This distinction was validated by later wholerock geochemical analyses). Although aphyric, the majority of cores contain from $<1 \%$ to trace amounts of plagioclase and/or olivine and pyroxene phenocrysts, set within a cryptocrystalline to fine-grained groundmass. The groundmass consists of microlites to microlaths of plagioclase and/or olivine, pyroxene, opaque oxides, and opaque sulfides, with the plagioclase forming an intersertal to intergranular texture. All other phases, as well as the mesostasis, occur interstitially.

Vesicularity within the massive ferrobasalts varies from sparse (Sections 168-1025C-3R-2 through 4R-3 are devoid of vesicles) to $\sim 14 \%$, consisting of round to ovoid gas and round segregation vesicles. Within Sections 168-1025C-1R-2 through 1R-3 and 5R-1 through $5 \mathrm{R}-3$, there is a progressive change in vesicle abundance and size (Fig. 12A-C). From the top to the middle of each series of core sections, the vesicles gradually increase in diameter $(1-6 \mathrm{~mm})$ and abundance $(5 \%-12 \%$; Fig. 12A, B). In the lower half of each series, the vesicles decrease in size $(2.5-1 \mathrm{~mm})$ and abundance (from $5 \%$ to $<1 \%$; Fig. 12C). Where vesicularity drops to $<1 \%$, a trace amount of 

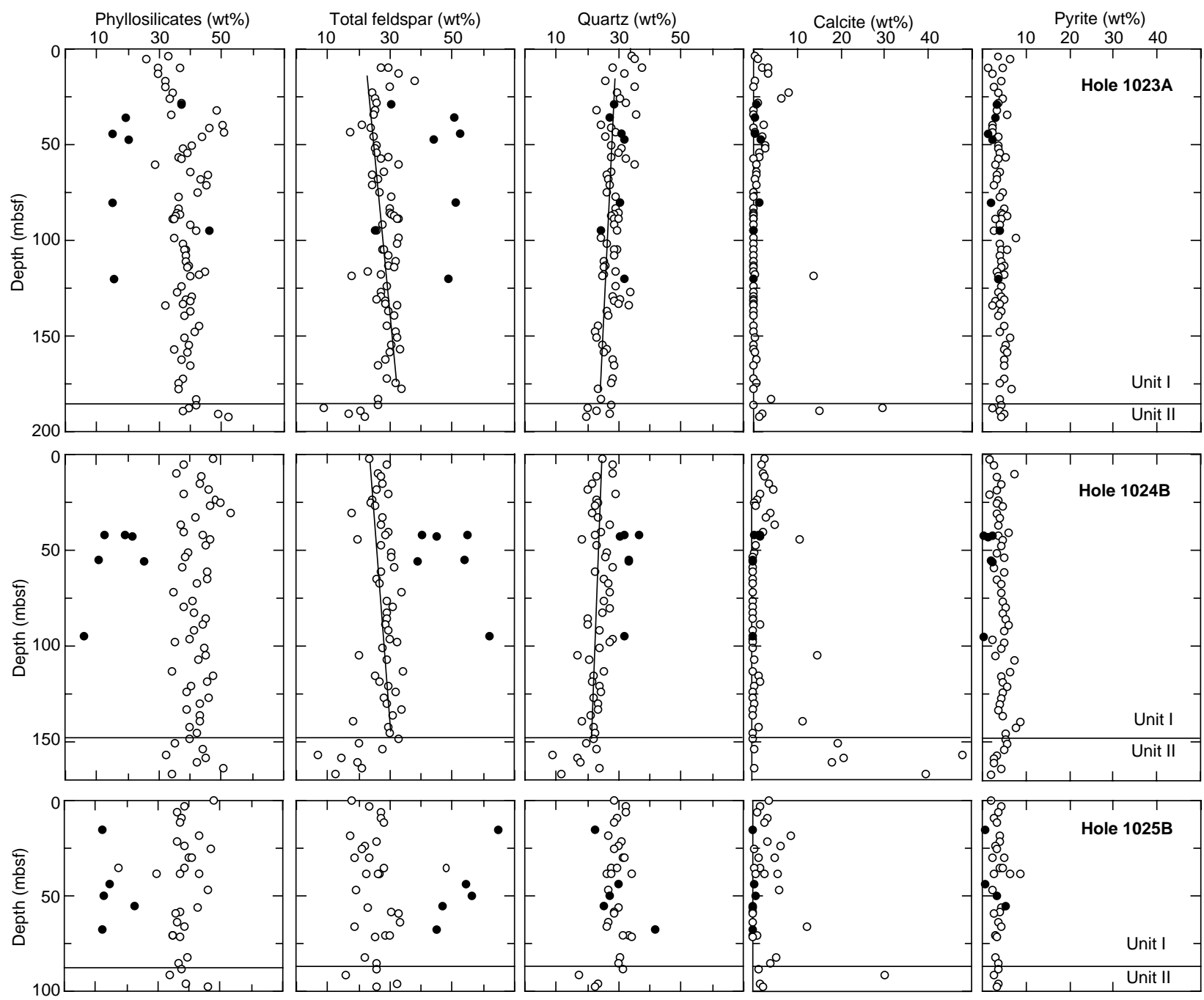

Figure 10. Depth distribution of major mineral phases (in relative weight percentages) in Holes 1023A, 1024B, and 1025B, based on X-ray diffraction analyses of bulk powders. Open circles $=$ samples of hemipelagic mud and carbonate-rich mud; solid circles $=$ samples of turbidite sand and silty sand .

ovoid to round vugs ( $\leq 15 \mathrm{~mm}$ diameter) is present within some of the massive ferrobasalts (Fig. 13). This progressive variation in vesicle abundance may represent a massive flow unit that, as it cooled, began to degas, allowing vesicles to rise up through the flow toward the upper half. The decrease in size and abundance of vesicles toward the upper margin of the flow can be explained most readily by a more rapid cooling rate. Likewise, the lack of vesicles at the lower margin can also be attributed to a more rapid cooling rate at the lower flow boundary. Compression within the lower half of the flow, associated with a longer crystallization period, may account for the lack of large vesicles in this region.

\section{Igneous Petrology}

Two samples from Hole 1023A, two from Hole 1024B, two from Hole 1024C, two from Hole 1025B, and 13 from Hole 1025C were selected for petrographical analyses, covering the three types of basalt defined at the Hydrothermal Transition sites (i.e., aphyric pillow basalts [Holes 1023A-1025B], sparsely to moderately phyric pillow basalts [Holes 1023A and 1025B], and aphyric massive ferrobasalts [Hole 1025C]). Table 6 summarizes the lithologic units, rock types, diagnostic features, and abundances and morphologies of the pheno- cryst and groundmass minerals present at the Hydrothermal Transition sites; Table 7 lists the phenocryst and groundmass mineral modal abundances within each sample analyzed. The petrology of the Hydrothermal Transition basalts will be discussed in order of rock-type abundance. Secondary mineralogy caused by hydrothermal alteration will be discussed in full in the "Basement Alteration" subsection (below).

\section{Aphyric Massive Ferrobasalt}

All cores recovered from Hole $1025 \mathrm{C}$ consist of aphyric massive ferrobasalt, which contains trace amounts of plagioclase and olivine phenocrysts (Tables 6, 7). Whole-rock geochemical analyses allowed the massive basalts to be accurately classified as ferrobasalts (see the "Igneous Geochemistry" subsection below for a full discussion.) The massive ferrobasalt sequence was divided into eight subunits (Units $1 \mathrm{a}-\mathrm{i}$ ), based upon the presence of glassy chilled margins and/or changes in grain size, crystallinity, and vesicularity. Petrologic investigations reveal that a subtle change in grain size and texture can be detected within most subunits. As the distance from the top of each subunit increases, the grain size changes from glassy to cryptocrystalline, microcrystalline, and fine-grained; the texture simultaneously 


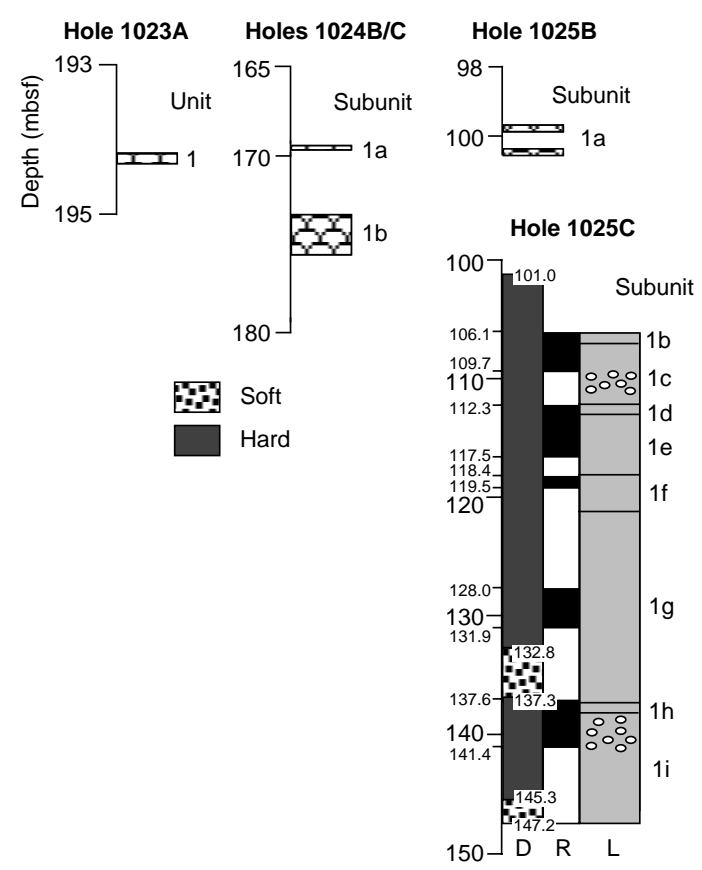

Figure 11. Lithostratigraphic logs for igneous rocks from Holes 1023A, 1024B, 1024C, 1025B, and 1025C. Column D = the drilling record for Hole $1025 \mathrm{C}$; column $\mathrm{R}=$ actual extent of recovery for Hole $1025 \mathrm{C}$, indicated graphically by horizontal black bars; and column $\mathrm{L}=$ the lithologic record for all holes. The lithologic units are shown with recovery (always <100\%) expanded to fit the interval cored. The patterns used are the same as those in Figure 3 in the "Methods" chapter (this volume); no pattern has been assigned to the overlying or interbedded sediments.

changes from hypohyaline, to hypocrystalline, subvariolitic (primarily sheaf-spherulitic), glomeroporphyritic, intersertal, and, finally, intergranular. There is also a progressive increase in the average grain size down the whole massive ferrobasalt sequence, which changes from predominantly cryptocrystalline at the top (Subunit 1b) to mixed cryptocrystalline-microcrystalline in the middle (Subunits $1 \mathrm{c}-\mathrm{f}$ ) to microcrystalline and fine grained near the base (Subunits $1 \mathrm{~g}-\mathrm{i}$; Table 8 ). These changes may indicate a progressive decrease in the cooling period with time.

All massive ferrobasalts regardless of grain size and texture contain trace amounts of plagioclase phenocrysts (Fig. 14A), whereas less than $25 \%$ of the basalts contain plagioclase and olivine phenocrysts (Fig. 14B). The plagioclase phenocrysts $(0.4-1.7 \mathrm{~mm}$; average $=0.8 \mathrm{~mm}$ ) generally form euhedral to subhedral stubby and elongate laths that are present singly as well as within monomineralic and bimineralic glomeroporphyritic clots. Solitary plagioclase grains frequently exhibit simple or oscillatory zoning. The olivine phenocrysts $(0.3-1.6 \mathrm{~mm}$; average $=0.7 \mathrm{~mm})$ have all been replaced either completely or partially by cryptocrystalline and secondary hydrothermal saponite. (Section 168-1025C-5R-1 differs in that it contains olivine phenocrysts that have been replaced by saponite and talc.) The olivine pseudomorphs are euhedral, and point counting indicates that they were originally present in trace amounts.

The groundmass of the aphyric massive ferrobasalts consists of varying amounts of plagioclase, olivine, pyroxene, opaque oxides, and sulfides, with mesostasis present in hypocrystalline to intersertal varieties (Fig. 14A, B). Plagioclase has an average abundance of $31 \%$ (ranging from $7 \%$ to $49 \%$ ) and forms 0.05 - to 1.5 - $\mathrm{mm}$ (average $=0.4$ $\mathrm{mm}$ ) euhedral to skeletal microlaths, microlites, and quench crystals (consisting of swallowtail and hollow forms). These grains frequently exhibit weak to strong simple zoning and are present singly within the mesostasis, as well as within stellate clusters, and in monomineralic and bimineralic (plagioclase + pyroxene) microglomeroporphyritic clots. In some units (e.g., Section 168-1025C-5R-1), the plagioclase microcrysts exhibit a weak to moderate parallel orientation, perpendicular to the top of the core. In the more crystalline massive ferrobasalts (Subunits 1e-i), the plagioclase microcrysts form a weak to well-developed intersertal to intergranular framework (Fig. 14A).

As with the olivine phenocrysts, virtually all groundmass olivine has been replaced by secondary cryptocrystalline granular and/or fibrous saponite, with trace to $1 \%$ remnant grains of fresh olivine present in only two sections (168-1025C-3R-1 and 4R-1); original abundances varied from $0.8 \%$ to $3.5 \%$ (average $=2 \%$ ). Euhedral to subhedral olivine microcrysts vary from 0.1 to $0.4 \mathrm{~mm}$ (average $=0.3$ $\mathrm{mm}$ ) and are present as solitary crystals within the mesostasis, either partially enclosing plagioclase-pyroxene glomeroporphyritic clots or interstitial to plagioclase.

The relative abundance of groundmass pyroxene within the massive ferrobasalts varies from $4 \%$ to $36 \%$ (average $=23 \%$ ). Morphologically, the grains are subhedral to anhedral, 0.05-0.6 mm (average $=0.2 \mathrm{~mm}$ ) and are present as solitary, granular crystals in the mesostasis, intergrown with plagioclase at the center of stellate clusters or microglomeroporphyritic clots, or as an interstitial phase within the intergranular basalts. The crystals commonly exhibit a weak pale pink to brown pleochroism, implying they may be iron rich.

Primary magmatic opaque oxides (magnetite \pm ilmenite lamellae) and/or opaque sulfides (pyrite \pm pyrrhotite \pm chalcopyrite) are disseminated throughout the groundmass and/or within plagioclase phenocrysts (Fig. 15). Magnetite forms euhedral to subhedral grains $(0.05-0.5 \mathrm{~mm}$; average $=0.09 \mathrm{~mm})$ that frequently contain lamellae of ilmenite, whereas in some sections, trace amounts of ilmenite form discrete skeletal grains. The total abundance of opaque oxides varies from $0.8 \%$ to $9.2 \%$ (average $=7.2 \%$ ). The most common magmatic sulfide phase is pyrite, present in trace amounts as 0.01 - to $0.06-\mathrm{mm}$ (average $=0.04-\mathrm{mm}$ ) globules and rods, frequently intergrown with pyrrhotite and/or chalcopyrite. The perfectly spherical globules may represent droplets that were immiscible within the original magma. Within Sample 168-1025C-5R-1 (Piece 7, 38-42 cm), trace amounts of $0.3-$ to $0.5-\mathrm{mm}$ subhedral to anhedral pyrite grains are present, with one grain containing a triangular $0.05-\mathrm{mm}$ chalcopyrite grain (Fig. 15).

Where present, the mesostasis consists of cryptocrystalline dark brown to brown-gray material, characterized by either a sheafspherulitic, plumose, or massive texture, frequently containing feathery plumes of cryptocrystalline granules (possibly pyroxene) and microlites of plagioclase, pyroxene, and opaque minerals. Throughout the massive ferrobasalt, the mesostasis has been altered to varying extents from slight $(<10 \%)$ to complete $(>95 \%)$. This has changed the original abundances of mesostasis present in the sections from $13 \%-$ $86 \%$ (average $=37 \%)$ to $0 \%-86 \%$ (average $=28 \%$ ). Where altered, the mesostasis is replaced by fibrous to granular saponite, although in Section 168-1025C-5R-1, the mesostasis also exhibits replacement by colorless zeolite and blue-green chlorite/smectite.

Throughout the aphyric massive ferrobasalt sequence, vesicularity varies from a trace amount to $\leq 14 \%$, generally decreasing as crystallinity increases. More than $75 \%$ of all samples analyzed petrographically contain between $0.4 \%$ and $14 \%$ (average $=3 \%$ ) round to irregular gas vesicles and/or between a trace amount and $1.6 \%$ (average $=<1 \%)$ round to ovoid segregation vesicles $(0.3-0.7 \mathrm{~mm}$; average $=0.5 \mathrm{~mm}$ ). All other samples were devoid of any optically visible vesicles (Table 6). All gas vesicles are either empty or contain a fine layer $(\leq 0.05 \mathrm{~mm})$ of fibrous saponite \pm solitary sulfide grains on their inner edges. Gas vesicles within Sample 168-1025C-2R-4 (Piece 12, 
Table 6. Summary of the rock types, lithologic units, and range of phenocrysts and groundmass minerals present at Holes 1023A, 1024B, 1024C, 1025B, and 1025C, listing the diagnostic petrologic features of each unit.

\begin{tabular}{|c|c|c|c|c|c|}
\hline $\begin{array}{l}\text { Hole: } \\
\text { Rock type: } \\
\text { Unit: }\end{array}$ & $\begin{array}{c}1023 \mathrm{~A} \\
\text { Sparsely to moderately phyric basalt } \\
\text { 1a }\end{array}$ & $\begin{array}{c}\text { 1024B } \\
\text { Aphyric basalt } \\
\text { 1a } \\
\end{array}$ & $\begin{array}{c}1024 \mathrm{C} \\
\text { Aphyric basalt } \\
1 \mathrm{~b}\end{array}$ & $\begin{array}{c}1025 \mathrm{~B} \\
\text { Aphyric to sparsely phyric basalt } \\
1 \mathrm{a}\end{array}$ & $\begin{array}{c}1025 \mathrm{C} \\
\text { Aphyric massive ferrobasalt } \\
1 \mathrm{~b}-\mathrm{i} \\
\end{array}$ \\
\hline \multicolumn{6}{|l|}{ Hand specimen } \\
\hline Structure: & Pillow basalts & Pillow basalts & Pillow basalts & Pillow basalts & Massive basalts \\
\hline Texture: & Variolitic to subvariolitic & Variolitic to subvariolitic & Variolitic to intergranular & Variolitic to intersertal & Intersertal to intergranular \\
\hline $\begin{array}{l}\text { Graan size: } \\
\text { Crystallinity: }\end{array}$ & $\begin{array}{l}\text { Aphanitic } \\
\text { Hypohyaline to hypocrystalline }\end{array}$ & $\begin{array}{l}\text { Aphanitic } \\
\text { Hypohyaline to hypocrystalline }\end{array}$ & $\begin{array}{c}\text { Aphanitic } \\
\text { Hypohyaline to hypocrystalline }\end{array}$ & $\begin{array}{l}\text { Microcrystalline } \\
\text { Hypocrystalline }\end{array}$ & $\begin{array}{l}\text { Aphanitic to fine grained } \\
\text { Hypocrystalline to holocrystalline }\end{array}$ \\
\hline Vesicles & & & & & \\
\hline Gas (\%): & $\leq 1.6$ & $\leq 1.8$ & $0.8-3.5$ & $\leq 2.5$ & $0.4-14$ \\
\hline \multicolumn{5}{|l|}{ Phenocrysts } & Tr to 1.6 \\
\hline Plagioclase (\%): & $\leq 4$ & $\operatorname{Tr}$ to 0.1 & $\operatorname{Tr}$ & $\operatorname{Tr}$ to 0.6 & $\operatorname{Tr}$ to 0.5 \\
\hline Morphology: & Euhedral to subhedral & Euhedral to subhedral & Euhedral & Euhedral & $\begin{array}{c}\text { Ir to } 0.5 \\
\text { Euhedral to subhedral }\end{array}$ \\
\hline Size range (mm): & $0.3-2$ & $0.1-1.6$ & $0.5-1.2$ & $\leq 1.5$ & $0.4-1.7$ \\
\hline Olivine (\%): & $\leq 1.2$ & - & - & $0-1$ & 0 to tr \\
\hline Morphology: & Euhedral to subhedral & - & - & Euhedral to subhedral & Euhedral \\
\hline Size range $(\mathrm{mm})$ : & $0.1-0.5$ & - & - & $0.1-0.4$ & $0.3-1.6$ \\
\hline Pyroxene (\%): & - & $\operatorname{Tr}$ & - & Tr to 1 & - \\
\hline Morphology: & - & Subhedral to euhedral & - & Euhedral & - \\
\hline \multirow{2}{*}{\multicolumn{6}{|c|}{ Groundmass }} \\
\hline & & & & & \\
\hline Plagioclase (\%): & $4-17$ & $5-11$ & $\leq 8$ & $9-14$ & $7-49$ \\
\hline Morphology: & Euhedral to skeletal & Euhedral to skeletal & Euhedral to subhedral & Euhedral to skeletal & Euhedral to skeletal \\
\hline Size range (mm): & $\leq 0.5$ & $0.03-0.15$ & $\leq 0.1$ & $0.1-0.2$ & $0.05-1.5$ \\
\hline $\begin{array}{l}\text { Olivine (\%): } \\
\text { Ollit). }\end{array}$ & $2-4$ & 0 to tr & 0 to tr & $0-0.2$ & $0-3.5$ \\
\hline Morphology: & Subhedral to euhedral & Subhedral to euhedral & Euhedral & Euhedral to subhedral & Euhedral to subhedral \\
\hline Size range (mm): & $\leq 0.3$ & $0.05-0.1$ & $\leq 0.1$ & $0.1-0.4$ & $0.1-0.4$ \\
\hline Pyroxene $(\%)$ & $\operatorname{Tr}$ & $3-7.5$ & $\leq 10$ & $5-10$ & $4-36$ \\
\hline Morphology: & Granular & Euhedral to subhedral & Granular & Euhedral to anhedral & Subhedral to anhedral \\
\hline Size range $(\mathrm{mm})$ : & $<0.05$ & $0.05-0.2$ & $0.02-0.05$ & $0.1-0.2$ & $0.05-0.6$ \\
\hline Opaque minerals (\%): & $\operatorname{Tr}$ (sulfides) & $\operatorname{Tr}$ (sulfides) & $\operatorname{Tr}$ (sulfides) & $\operatorname{Tr}$ (sulfides) & $\leq 9.2$ (oxides + sulfides $)$ \\
\hline Morphology: & Granular & Granular & Granular & Granular & Euhedral to skeletal \\
\hline Size range $(\mathrm{mm})$ : & $0.01-0.02$ & $\leq 0.02$ & $\leq 0.005$ & $\leq 0.05$ & $0.05-0.5$ \\
\hline Glass $(\%)$ : & $\operatorname{Tr}$ & $0.7-3.5$ & $\operatorname{Tr}$ & $\leq 1$ & - \\
\hline Microlites (\%): & & Plagioclase, pyroxene, and olivine & Plagioclase & & - \\
\hline Mesostasis (\%): & $70-88$ & $79-86$ & $80-98$ & $70-80$ & $0-86$ \\
\hline Texture: & $\begin{array}{l}\text { Subvariolitic (sheaf-spherulitic) to } \\
\text { intersertal }\end{array}$ & $\begin{array}{l}\text { Subvariolitic: plumose, branching, and } \\
\text { honeycomb }\end{array}$ & $\begin{array}{l}\text { Subvariolitic: sheaf-spherulitic to } \\
\text { plumose }\end{array}$ & Subvariolitic: sheaf-spherulitic & Subvariolitic (sheaf-spherulitic) to intersertal \\
\hline
\end{tabular}

Note: $-=$ not observed, and $\operatorname{tr}=$ trace amount 
A

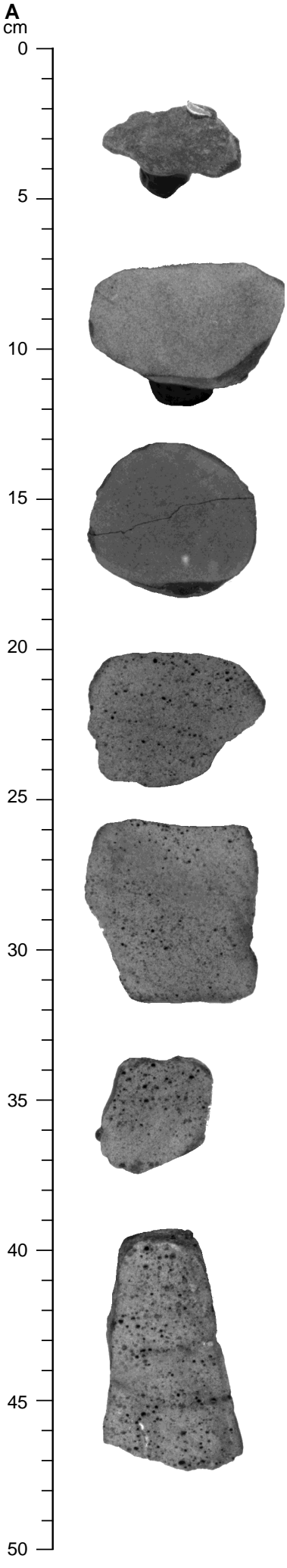

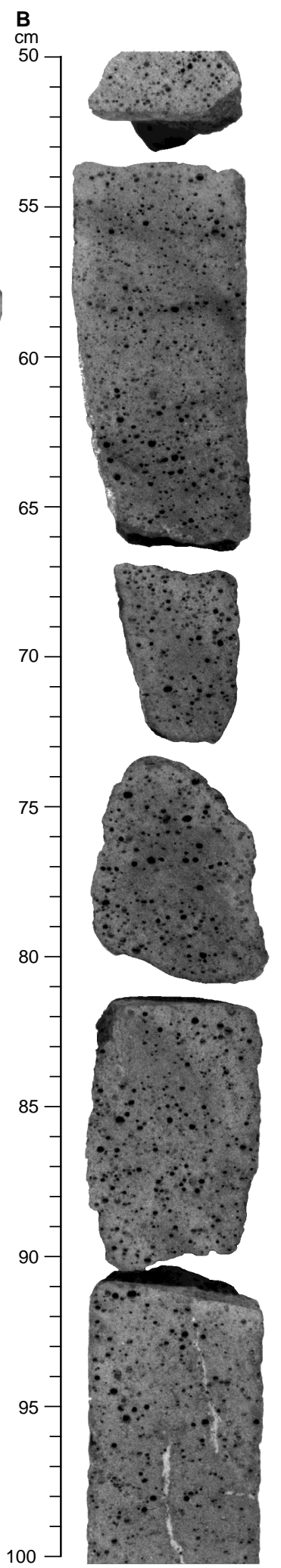

c

$c m$
100

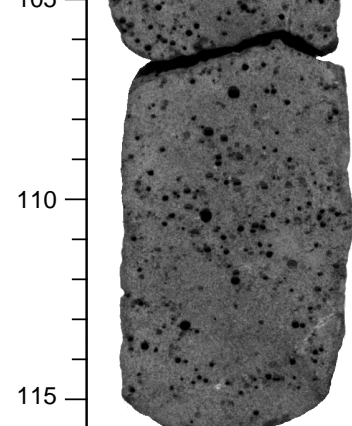

$115-(\because \cdots,:)$
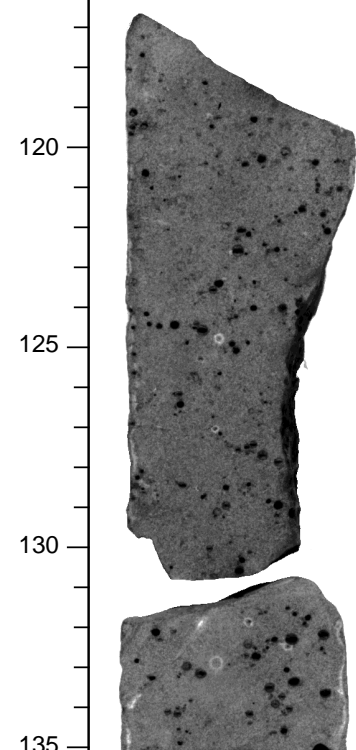

135

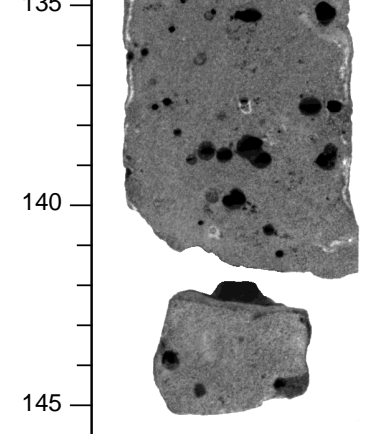

Figure 12. Series of photographs showing the progressive change in vesicularity and grain size down section within $(\mathbf{A})$ interval $168-1025 \mathrm{C}-5 \mathrm{R}-1,0-50 \mathrm{~cm},(\mathbf{B})$ interval 168-1025C-5R-1, 50-100 cm; and (C) interval 168-1025C-5R-1, 100-147 cm. 


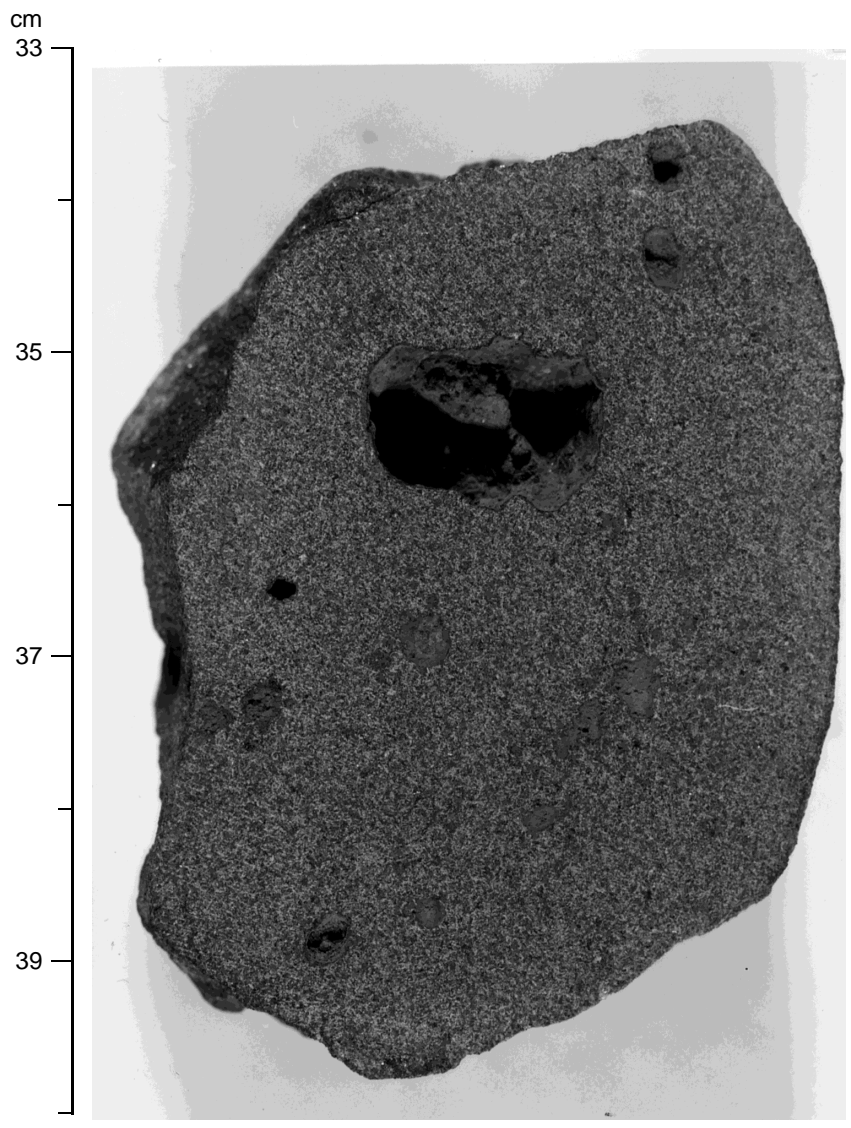

Figure 13. Photograph of a $15-\mathrm{mm}$ vug lined by secondary pyrite (about 0.1 $\mathrm{mm}$ thick) followed by dark green saponite in Sample 168-1025C-1R-3 (Piece 6, 33-40 cm).

$54-58 \mathrm{~cm}$ ) are unique in that they also contain stellate, hemispherical clusters of aragonite needles that radiate into the center of the vesicles (see "Basement Alteration" below).

Segregation vesicles are completely to partially filled by mesostasis \pm opaque rods and microlites of plagioclase and pyroxene. In some partially filled segregation vesicles, a gas bubble has been enclosed, whereas in others, the infill has taken on a geopetal structure. Gas vesicles within segregation vesicles are generally lined by a $\leq 0.05$-mm layer of fibrous saponite, whereas within Section 168$1025 \mathrm{C}-1 \mathrm{R}-2$ the gas vesicles are also finely coated by a layer of fibrous-crystalline colorless zeolite. In many cores, a continuum exists between segregation and gas vesicles, varying from (1) completely filled (Fig. 16A); (2) partially filled segregation vesicles (Fig. $16 \mathrm{~B})$; (3) geopetal fills of mesostasis $(\leq 0.1 \mathrm{~mm}$ thick) within the vesicles, most of which are present at the base of the vesicle, with the geopetal infill and the rest of the vesicle lined by a $\leq 0.05$-mm layer of fibrous saponite (Fig. 16C); and (4) empty gas vesicles, lined by a $\leq 0.05$-mm layer of saponite (Fig. 16D). Throughout cores from Hole $1025 \mathrm{C}$, the aphyric massive ferrobasalts vary from being fresh $(<2 \%$ alteration) to moderately altered ( $<25 \%$ alteration).

\section{Aphyric Pillow Basalt}

The aphyric pillow fragments recovered from Holes 1023A, $1024 \mathrm{~B}, 1024 \mathrm{C}$, and 1025B, are designated as Unit 1a for all holes (Table 6). The presence of glassy, chilled margins on some of the fragments, along with the variolitic to subvariolitic textures within the rock fragments, permitted the structure of the subunit to be established, with some degree of certainty. (No aphyric pillow fragment was selected for petrographical analysis from Hole 1023A; the following descriptions are based upon samples from Holes 1024B, $1024 \mathrm{C}$, and 1025B.)

Comparisons between the aphyric pillow basalts from Holes $1024 \mathrm{~B}, 1024 \mathrm{C}$, and $1025 \mathrm{~B}$ indicate that subtle differences in the types of trace phenocrysts present, whole-rock texture, and grain size exist among the three holes. Pillow basalts from Holes 1024B and $1024 \mathrm{C}$ contain trace amounts of plagioclase $(0.1-1.2 \mathrm{~mm}$; average $=$ $0.5 \mathrm{~mm}) \pm$ pyroxene $(0.2-0.3 \mathrm{~mm}$; average $=0.25 \mathrm{~mm})$ and are characterized by a variolitic to subvariolitic texture (Fig. 17A), whereas the pillow basalts from Hole 1025B contain trace amounts of plagioclase $(\leq 0.8 \mathrm{~mm})$, olivine $(0.1-0.4 \mathrm{~mm})$, and pyroxene $(\leq 0.8 \mathrm{~mm})$ and have a sheaf-spherulitic to intersertal texture (Fig. 17B). Plagioclase phenocrysts from both holes are euhedral to subhedral, occur as solitary crystals as well as within monomineralic and bimineralic glomeroporphyritic clots (plagioclase + pyroxene; Hole 1024B), and frequently exhibit simple to oscillatory zoning. In contrast, the pyroxene phenocrysts (also euhedral to subhedral) are generally intergrown or associated with the plagioclase phenocrysts in bimineralic glomeroporphyritic clots. All olivine phenocrysts within the pillow basalts from Hole 1025B are subhedral to euhedral and have been completely replaced by secondary clay minerals.

The groundmass mineralogy is less variable than the phenocryst assemblage, consisting of microlites and microlaths of plagioclase, pyroxene, olivine, primary magmatic pyrite, and pyrrhotite. Groundmass plagioclase $(0.03-0.2 \mathrm{~mm} ; 5 \%-14 \%)$ forms euhedral and skeletal microlaths and quench crystals. The microlaths are either distributed randomly throughout the mesostasis, or located within stellate clusters, associated with microlites of pyroxene ( \pm olivine), which form 0.05 - to $0.2-\mathrm{mm}$ euhedral to subhedral crystals. Olivine forms subhedral to euhedral microcrysts, varying from 0.05 to $0.4 \mathrm{~mm}$. No fresh olivine is present within the groundmass from either hole, although point counts indicate that olivine originally had an abundance of trace to $2 \%$. Trace amounts of granular pyrite and pyrrhotite $(\leq 0.02 \mathrm{~mm})$ are disseminated throughout the groundmass.

Differences do occur in the grain size and texture of the mesostasis, however. Several of the aphyric pillow basalts from Holes 1024B and $1024 \mathrm{C}$ are topped by a glassy, chilled margin $(0.6-2.5 \mathrm{~mm}$ thick) containing well-developed varioles centered around microlites of plagioclase, pyroxene, and/or olivine. Increasing distance from this chilled margin shows a progressive change in mesostasis texture and color from dark brown subvariolitic, to deep red plumose, to dark gray-brown plumose (Fig. 17A), and finally, to gray-brown branching texture. The cryptocrystalline mesostasis represents $79 \%-86 \%$ of the total rock abundance. The aphyric pillow basalts from Hole $1025 \mathrm{~B}$ contain $\leq 70 \%$ microcrystalline mesostasis material, characterized by a subvariolitic (sheaf-spherulitic) to intersertal texture (Fig. 17B). Within the mesostasis, microcrystalline grains of plagioclase, pyroxene, skeletal magnetite, and pyrite are present.

All aphyric basalts are vesicular and contain $1.4 \%-3.4 \%$ round to irregular gas vesicles, which are either empty or finely lined by hydrothermal clays (e.g., saponite, celadonite, and iddingsite) \pm pyrite. The range in vesicle diameter varies among samples from Holes $1024 \mathrm{~B}$ and $1024 \mathrm{C}$ and Hole $1025 \mathrm{~B}$ and is equivalent to $0.05-0.1 \mathrm{~mm}$ and $0.2-0.6 \mathrm{~mm}$, respectively. Whole-rock alteration of samples from Holes $1024 \mathrm{~B}$ and $1025 \mathrm{~B}$ is $<2 \%$, categorizing the aphyric pillow basalts as fresh; Hole $1024 \mathrm{C}$ samples are slightly altered, with $<3 \%$ alteration.

\section{Sparsely to Moderately Phyric Pillow Basalts}

Sparsely to moderately phyric pillow basalts were sampled within Sections 168-1023A-22X-CC and 1025B-11X-CC. The rocks are 
Table 7. Modal mineral abundances for all thin-section analyses conducted on samples from Holes 1023A, 1024B, 1024C, 1025B, and 1025C.

\begin{tabular}{|c|c|c|c|c|c|c|c|c|c|c|c|c|}
\hline \multirow[b]{2}{*}{ Sample } & \multirow[b]{2}{*}{ Structure } & \multicolumn{3}{|c|}{ Phenocrysts } & \multicolumn{5}{|c|}{ Groundmass } & \multicolumn{2}{|c|}{ Vesicles } & \multirow{2}{*}{$\begin{array}{l}\text { Secondary } \\
\text { alteration } \\
(\%)\end{array}$} \\
\hline & & $\begin{array}{l}\text { Olivine }^{\mathrm{a}} \\
(\%)\end{array}$ & $\begin{array}{c}\text { Clinopyroxene } \\
(\%)\end{array}$ & $\begin{array}{l}\text { Plagioclase } \\
\text { (\%) }\end{array}$ & $\begin{array}{l}\text { Olivine }^{\mathrm{a}} \\
(\%)\end{array}$ & $\begin{array}{l}\text { Clinopyroxene } \\
(\%)\end{array}$ & $\begin{array}{l}\text { Plagioclase } \\
\quad \%)\end{array}$ & $\begin{array}{l}\text { Opaque minerals } \\
(\%)\end{array}$ & $\begin{array}{c}\text { Mesostasis }^{\mathrm{b}} \\
(\%)\end{array}$ & $\begin{array}{l}\text { Gas } \\
(\%)\end{array}$ & $\begin{array}{l}\text { Segregation } \\
(\%)\end{array}$ & \\
\hline $\begin{array}{l}\text { 1023A-22X-CC (Piece 4, 34-40 cm) } \\
\text { 1023A-22X-CC (Piece 6, 34-40 cm) }\end{array}$ & $\begin{array}{l}\text { Pillow basalt } \\
\text { Pillow basalt }\end{array}$ & $\begin{array}{l}0.6 \\
1.2\end{array}$ & $\overline{-}$ & $\begin{array}{l}3.8 \\
3.6\end{array}$ & $\begin{array}{l}1.8 \\
4.0\end{array}$ & $\overline{-}$ & $\begin{array}{r}3.8 \\
17.0\end{array}$ & $\begin{array}{l}\text { ND } \\
\text { ND }\end{array}$ & $\begin{array}{l}87.8 \\
72.6\end{array}$ & $\begin{array}{l}0.6 \\
1.6\end{array}$ & - & $\begin{array}{l}\operatorname{Tr} \\
\operatorname{Tr}\end{array}$ \\
\hline $\begin{array}{l}\text { 1024B-18X-CC (Piece 3, 9-27 cm) } \\
\text { 1024B-18X-CC (Piece 12, 9-27 cm) }\end{array}$ & $\begin{array}{l}\text { Pillow basalt } \\
\text { Pillow basalt }\end{array}$ & - & $\begin{array}{l}\operatorname{Tr} \\
\operatorname{Tr}\end{array}$ & $\begin{array}{l}0.1 \\
\operatorname{Tr}\end{array}$ & $\overline{\operatorname{Tr}}$ & $\begin{array}{l}3.3 \\
7.6\end{array}$ & $\begin{array}{r}4.6 \\
11.3\end{array}$ & $\begin{array}{l}\mathrm{ND} \\
\mathrm{ND}\end{array}$ & $\begin{array}{l}89.8 \\
79.7\end{array}$ & $\begin{array}{l}1.8 \\
1.4\end{array}$ & - & $\begin{array}{l}0.4 \\
\operatorname{Tr}\end{array}$ \\
\hline $\begin{array}{l}\text { 1024C-1R-1 (Piece 1, 0-8 cm) } \\
\text { 1024C-1R-1 (Piece 2, 8-15 cm) }\end{array}$ & $\begin{array}{l}\text { Pillow basalt } \\
\text { Pillow basalt }\end{array}$ & 二 & - & $\begin{array}{l}\operatorname{Tr} \\
\operatorname{Tr}\end{array}$ & $\overline{\mathrm{Tr}}$ & $\begin{array}{r}0.4 \\
10.3\end{array}$ & $\begin{array}{l}1.6 \\
7.7\end{array}$ & $\begin{array}{l}\text { ND } \\
\text { ND }\end{array}$ & $\begin{array}{l}98.0 \\
81.6\end{array}$ & $\begin{array}{l}0.8 \\
3.4\end{array}$ & - & $\begin{array}{l}1.8 \\
2.9\end{array}$ \\
\hline $\begin{array}{l}\text { 1025B-11X-CC (Piece 2, 28-40 cm) } \\
\text { 1025B-11X-CC (Piece 3, 28-40 cm) }\end{array}$ & $\begin{array}{l}\text { Pillow basalt } \\
\text { Pillow basalt }\end{array}$ & $\begin{array}{l}\operatorname{Tr} \\
1.0\end{array}$ & $\begin{array}{l}\mathrm{Tr} \\
1.0\end{array}$ & $\begin{array}{c}\operatorname{Tr} \\
0.6\end{array}$ & $\begin{array}{l}2.0 \\
0.2\end{array}$ & $\begin{array}{l}9.4 \\
5.6\end{array}$ & $\begin{array}{r}14.0 \\
9.0\end{array}$ & $\begin{array}{l}\text { ND } \\
\text { ND }\end{array}$ & $\begin{array}{l}71.4 \\
81.2\end{array}$ & $\begin{array}{l}2.2 \\
1.4\end{array}$ & - & $\begin{array}{l}2.0 \\
1.2\end{array}$ \\
\hline 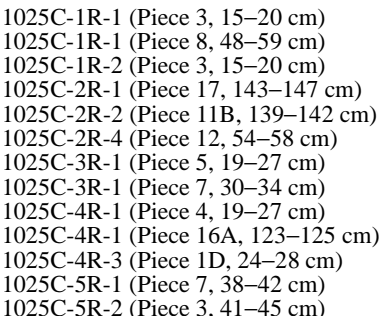 & $\begin{array}{l}\text { Massive ferrobasalt } \\
\text { Massive ferrobasalt } \\
\text { Massive ferrobasalt } \\
\text { Massive ferrobasalt } \\
\text { Massive ferrobasalt } \\
\text { Massive ferrobasalt } \\
\text { Massive ferrobasalt } \\
\text { Massive ferrobasalt } \\
\text { Massive ferrobasalt } \\
\text { Massive ferrobasalt } \\
\text { Massive ferrobasalt } \\
\text { Massive ferrobasalt } \\
\text { Massive ferrobasalt }\end{array}$ & $\begin{array}{l}\overline{\bar{T}} \\
\overline{\overline{T r}} \\
\overline{\operatorname{Tr}} \\
\overline{-} \\
\overline{-} \\
\overline{\overline{0.7}}\end{array}$ & $\begin{array}{l}= \\
= \\
= \\
= \\
= \\
= \\
=\end{array}$ & $\begin{array}{l}\operatorname{Tr} \\
1.0 \\
1.1 \\
0.2 \\
\operatorname{Tr} \\
\operatorname{Tr} \\
0.2 \\
0.4 \\
\operatorname{Tr} \\
\operatorname{Tr} \\
0.5\end{array}$ & $\begin{array}{l}2.4 \\
1.3 \\
1.8 \\
3.6 \\
3.6 \\
0.8 \\
2.2 \\
2.2 \\
2.2 \\
2.4 \\
2.8 \\
3.5 \\
3.0\end{array}$ & $\begin{array}{r}16.3 \\
4.3 \\
28.4 \\
27.1 \\
28.6 \\
22.0 \\
15.0 \\
4.0 \\
32.2 \\
31.4 \\
35.6 \\
26.4 \\
31.8\end{array}$ & $\begin{array}{r}24.3 \\
7.3 \\
43.2 \\
48.6 \\
40.6 \\
26.4 \\
18.4 \\
9.9 \\
26.0 \\
42.8 \\
37.4 \\
39.4 \\
39.0\end{array}$ & $\begin{array}{c}1.8 \\
\mathrm{ND} \\
9.1 \\
7.2 \\
7.8 \\
4.6 \\
\mathrm{ND} \\
0.8 \\
7.8 \\
6.2 \\
8.8 \\
9.2 \\
8.8\end{array}$ & $\begin{array}{l}54.9 \\
86.1 \\
13.2 \\
13.3 \\
19.4 \\
45.2 \\
63.2 \\
82.1 \\
30.4 \\
17.2 \\
15.4 \\
20.3 \\
17.4\end{array}$ & $\begin{array}{l}0.4 \\
0.9 \\
8.0 \\
\overline{\bar{Z}} \\
\overline{1.0} \\
1.0 \\
0.8 \\
1.4 \\
\overline{-} \\
\overline{14.2}\end{array}$ & $\begin{array}{l}0.4 \\
\bar{Z} \\
\bar{Z} \\
\overline{\mathrm{Tr}} \\
\mathrm{Tr} \\
\frac{\mathrm{Tr}}{Z} \\
\overline{-} \\
\overline{-}\end{array}$ & $\begin{array}{r}5.2 \\
1.3 \\
15.1 \\
19.7 \\
22.7 \\
10.0 \\
2.2 \\
1.4 \\
5.8 \\
15.3 \\
14.5 \\
24.5 \\
16.0\end{array}$ \\
\hline
\end{tabular}

Notes: Massive ferrobasalts are classified according to whole-rock geochemistry. $-=$ not observed. ND $=$ not determined individually; counted as mesostasis. $\mathrm{Tr}=$ trace amount.

${ }^{a}$ Olivine abundances represent the original abundance before alteration.

a Olivine abundances represent the original abundance before alteration.
bMesostasis abundances include any glass present in the thin section. 
Table 8. Summary of grain size variations within Subunits $1 \mathrm{~b}-\mathrm{i}$, within the aphyric massive ferrobasalt sequence, Hole $1025 \mathrm{C}$.

\begin{tabular}{|c|c|c|c|c|c|c|}
\hline Core & Section & Piece & $\begin{array}{l}\text { Interval } \\
(\mathrm{cm})\end{array}$ & Subunit & Texture & Grain size \\
\hline $1 \mathrm{R}$ & 1 & $1-4$ & $0-29$ & $1 b$ & Intersertal to intergranular & Cryptocrystalline \\
\hline $\begin{array}{l}1 \mathrm{R} \\
1 \mathrm{R} \\
1 \mathrm{R}\end{array}$ & $\begin{array}{l}1 \\
2 \\
3\end{array}$ & $\begin{array}{l}5-17 \\
1-20 \\
1-12\end{array}$ & $\begin{array}{c}29-139 \\
0-145 \\
0-78\end{array}$ & $\begin{array}{l}1 \mathrm{c} \\
1 \mathrm{c} \\
1 \mathrm{c}\end{array}$ & $\begin{array}{l}\text { Intersertal to intergranular } \\
\text { Intersertal to intergranular } \\
\text { Intersertal to intergranular }\end{array}$ & $\begin{array}{l}\text { Cryptocrystalline } \\
\text { Cryptocrystalline to microcrystalline } \\
\text { Microcrystalline }\end{array}$ \\
\hline $2 \mathrm{R}$ & 1 & $1-9$ & $0-55$ & $1 \mathrm{~d}$ & Hypocrystalline/subvariolitic & Cryptocrystalline to microcrystalline \\
\hline $\begin{array}{l}2 \mathrm{R} \\
2 \mathrm{R} \\
2 \mathrm{R} \\
2 \mathrm{R}\end{array}$ & $\begin{array}{l}1 \\
2 \\
3 \\
4\end{array}$ & $\begin{array}{l}10-17 \\
1-12 \\
1-15 \\
1-8\end{array}$ & $\begin{array}{c}55-148 \\
0-149 \\
0-150 \\
0-37\end{array}$ & $\begin{array}{l}\text { le } \\
1 \mathrm{e} \\
\text { le } \\
1 \mathrm{e}\end{array}$ & $\begin{array}{l}\text { Hypocrystalline to intergranular } \\
\text { Intergranular } \\
\text { Intergranular } \\
\text { Intergranular }\end{array}$ & $\begin{array}{l}\text { Microcrystalline } \\
\text { Microcrystalline to fine grained } \\
\text { Microcrystalline } \\
\text { Microcrystalline }\end{array}$ \\
\hline $\begin{array}{l}2 \mathrm{R} \\
3 \mathrm{R}\end{array}$ & $\begin{array}{l}4 \\
1\end{array}$ & $\begin{array}{l}9-15 \\
1-7\end{array}$ & $\begin{array}{r}37-72 \\
0-33\end{array}$ & $\begin{array}{l}\text { if } \\
\text { if }\end{array}$ & $\begin{array}{l}\text { Hypocrystalline to intergranular } \\
\text { Intergranular }\end{array}$ & $\begin{array}{l}\text { Cryptocrystalline to microcrystalline } \\
\text { Microcrystalline to fine grained }\end{array}$ \\
\hline $\begin{array}{l}3 R \\
3 R \\
4 R \\
4 R \\
4 R\end{array}$ & $\begin{array}{l}1 \\
2 \\
1 \\
2 \\
3\end{array}$ & $\begin{array}{l}8-11 \\
1-6 \\
1-16 \\
1-10 \\
1-7\end{array}$ & $\begin{array}{l}33-66 \\
0-42 \\
0-150 \\
0-135 \\
0-91\end{array}$ & $\begin{array}{l}1 \mathrm{~g} \\
1 \mathrm{~g} \\
1 \mathrm{~g} \\
1 \mathrm{~g} \\
1 \mathrm{~g}\end{array}$ & $\begin{array}{l}\text { Hypocrystalline/subvariolitic } \\
\text { Intergranular } \\
\text { Intersertal to intergranular } \\
\text { Intergranular } \\
\text { Intergranular }\end{array}$ & $\begin{array}{l}\text { Cryptocrystalline to microcrystalline } \\
\text { Microcrystalline } \\
\text { Cryptocrystalline to fine grained } \\
\text { Microcrystalline } \\
\text { Microcrystalline to fine grained }\end{array}$ \\
\hline $\begin{array}{l}4 \mathrm{R} \\
5 \mathrm{R}\end{array}$ & $\begin{array}{l}3 \\
1\end{array}$ & $\begin{array}{l}8 \\
1-3\end{array}$ & $\begin{array}{c}91-105 \\
0-18\end{array}$ & $\begin{array}{l}1 \mathrm{~h} \\
1 \mathrm{~h}\end{array}$ & $\begin{array}{l}\text { Hypocrystalline/subvariolitic } \\
\text { Intersertal }\end{array}$ & $\begin{array}{l}\text { Cryptocrystalline } \\
\text { Cryptocrystalline to microcrystalline }\end{array}$ \\
\hline $\begin{array}{l}5 \mathrm{R} \\
5 \mathrm{R} \\
5 \mathrm{R}\end{array}$ & $\begin{array}{l}1 \\
2 \\
3\end{array}$ & $\begin{array}{l}4-15 \\
1-11 \\
1-8\end{array}$ & $\begin{array}{c}18-147 \\
0-144 \\
0-91\end{array}$ & $\begin{array}{l}1 \mathrm{i} \\
1 \mathrm{i} \\
1 \mathrm{i}\end{array}$ & $\begin{array}{l}\text { Intersertal to intergranular } \\
\text { Intersertal to intergranular } \\
\text { Intergranular }\end{array}$ & $\begin{array}{l}\text { Microcrystalline } \\
\text { Microcrystalline to fine grained } \\
\text { Microcrystalline to fine grained }\end{array}$ \\
\hline
\end{tabular}

Notes: The average grain size increases within each subunit, associated with an increase in the crystallinity of the texture. An overall increase in grain size and crystallinity also occurs between the subunits $(1 \mathrm{~b}-\mathrm{i})$.
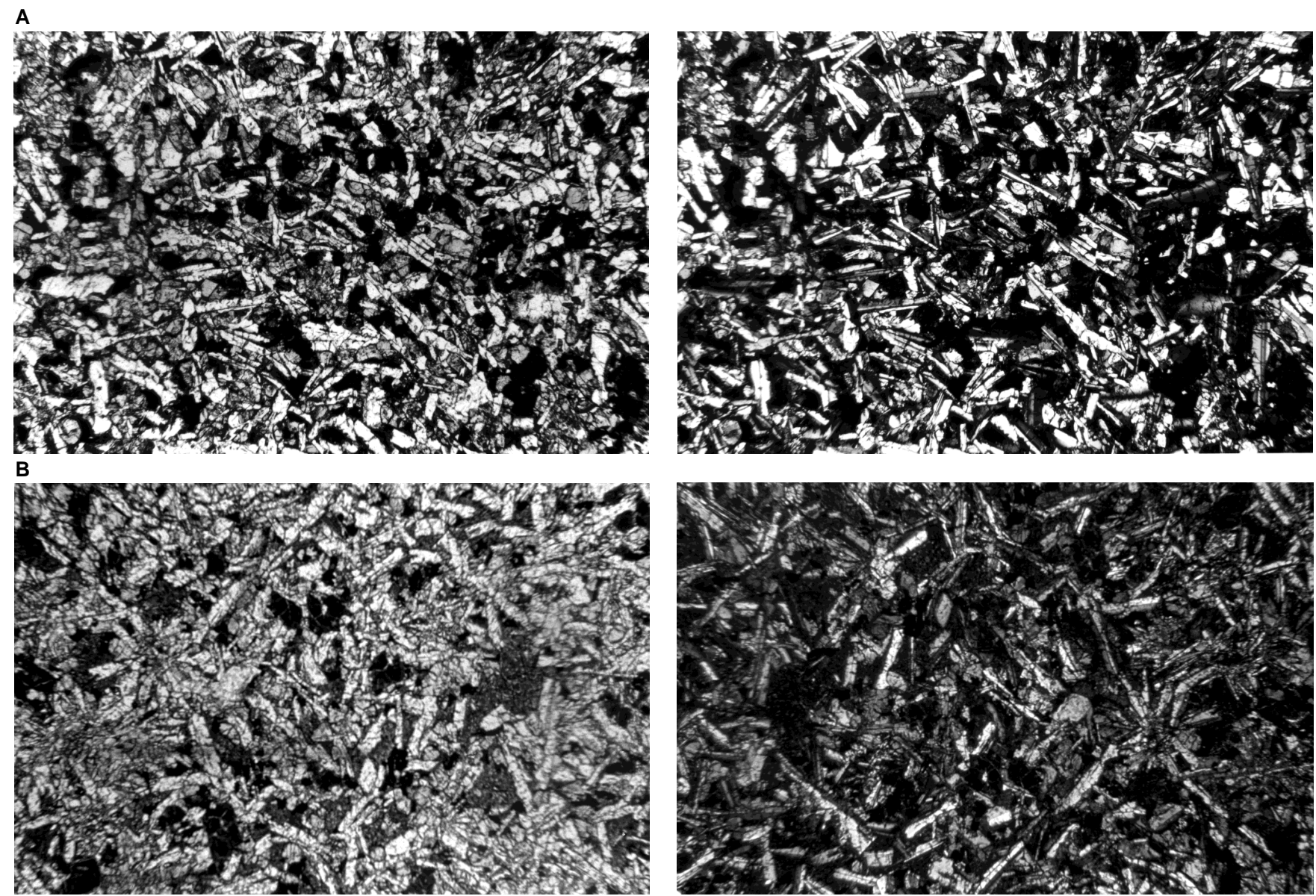

Figure 14. Photomicrographs of (A) a typical aphyric massive ferrobasalt containing only plagioclase phenocrysts with an intergranular to intersertal texture in plane-polarized light (left) and cross-polarized light (right) (Sample 168-1025C-4R-3 [Piece 10, 24-28 cm]) and (B) an aphyric massive ferrobasalt containing plagioclase and olivine phenocrysts with an intersertal texture in plane-polarized light (left) and cross-polarized light (right) (Sample 168-1025C-2R-1, [Piece $17,143-147 \mathrm{~cm}])$. Fields of view $=5.1 \mathrm{~mm}$. 


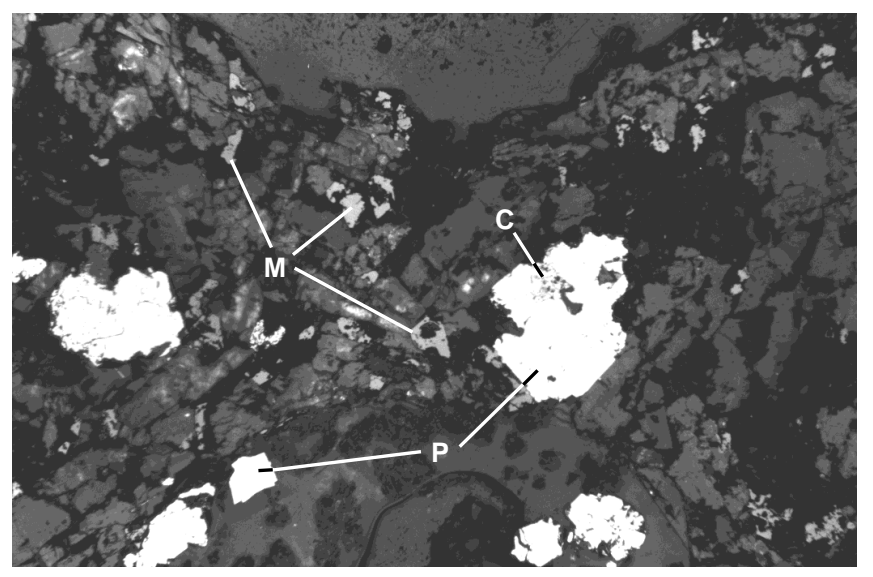

Figure 15. Reflected-light photomicrograph of anhedral to granular magnetite (M) $(\leq 0.05 \mathrm{~mm}$; gray) grains associated with larger, subhedral to anhedral $(0.3-0.5 \mathrm{~mm})$ white pyrite $(\mathrm{P})$ grains within the mesostasis of Sample 1681025C-5R-1 (Piece 7, 38-42 cm). A triangular chalcopyrite (C) grain (0.05 $\mathrm{mm}$ ) is encased within the large, central subhedral pyrite. (Two round vesicles are present at the top and bottom of the photomicrograph.) Field of view $=1.5 \mathrm{~mm}$. aphanitic and characterized by a variolitic to subvariolitic texture; slight variations occur within the phenocryst and groundmass mineral assemblages and abundances (Tables 6, 7).

The pillow basalt from Hole 1023A is moderately phyric, containing phenocrysts of plagioclase (average $=3.7 \%$ ) and olivine $(0.6 \%-$ $1.2 \%)$. Plagioclase forms euhedral to subhedral laths $(0.3-2 \mathrm{~mm})$ that commonly exhibit either simple, oscillatory, or sector zoning. In addition, the cores of several crystals are packed with clear to pale green-brown devitrified glass inclusions containing shrinkage bubbles. Olivine forms $0.1-$ to $0.5-\mathrm{mm}$ (average $=0.2-\mathrm{mm}$ ) euhedral to subhedral, fresh crystals that occur singly or intergrown with plagioclase (Fig. 18A).

In samples from Hole 1025B, subhedral plagioclase $(\leq 1.5 \mathrm{~mm})$, euhedral olivine $(0.2-0.4 \mathrm{~mm})$, and euhedral pyroxene $(0.1-0.9 \mathrm{~mm}$; average $=0.3 \mathrm{~mm}$ ) phenocrysts are present, equal to $1.6 \%-2.6 \%$ of the total rock volume (i.e., the pillow basalts are sparsely to moderately phyric) (Fig. 18B). The variation in the types of phenocryst phases present within the sparsely to moderately phyric pillow basalts from Holes 1024B, 1024C, and 1025B thus mirrors that previously seen within the aphyric pillow basalts. As at Hole 1023A, the plagioclase phenocrysts are commonly zoned (simple or oscillatory) and represent $0.6 \%$ of the total rock volume. However, the olivine phenocrysts from Hole 1025B are different than those from Hole 1023A, having been completely replaced by secondary saponite, iddingsite, and/or
A

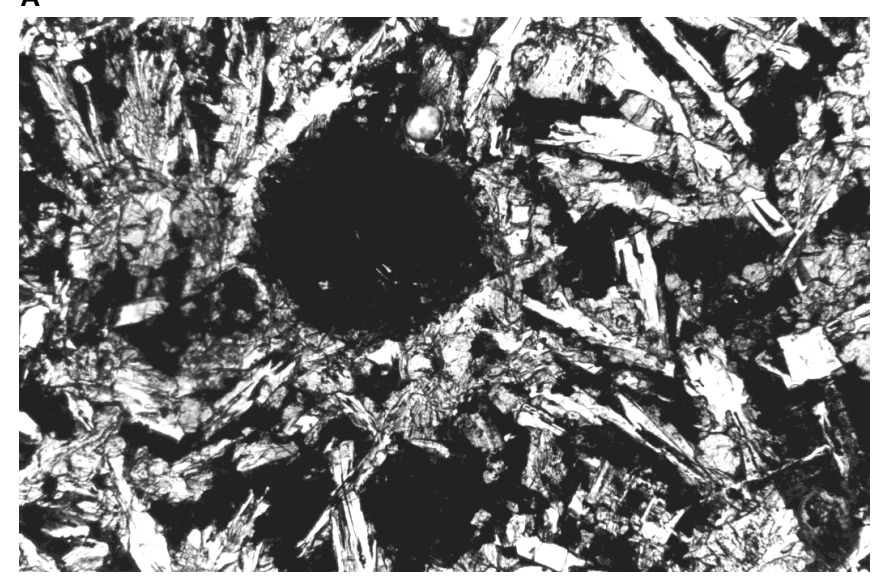

C

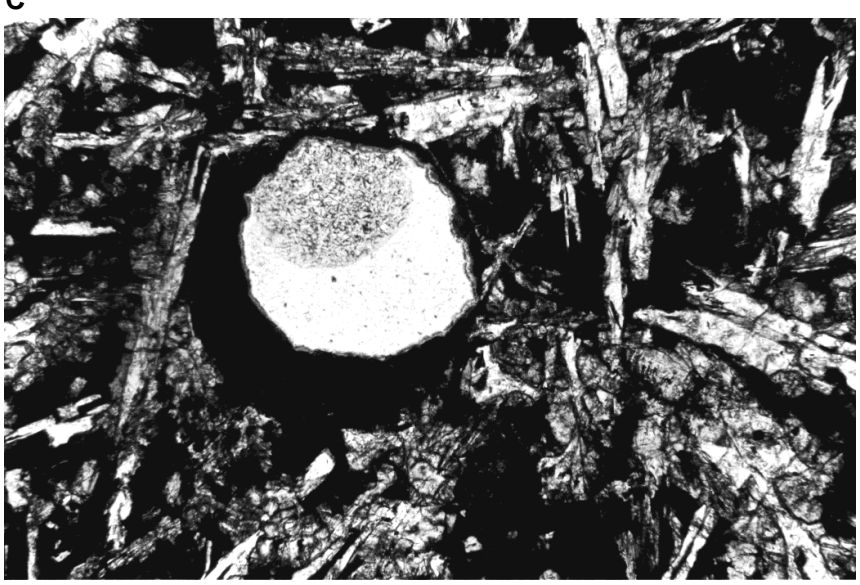

B

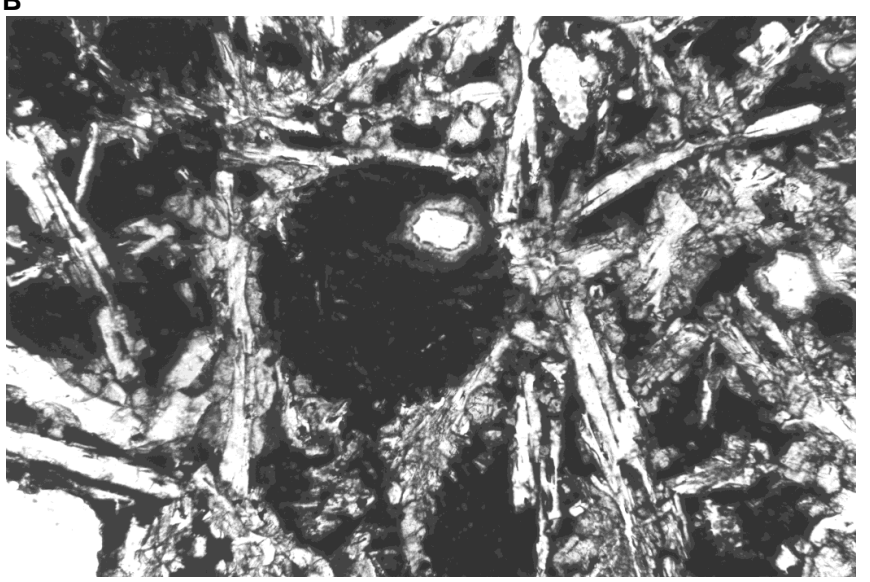

D

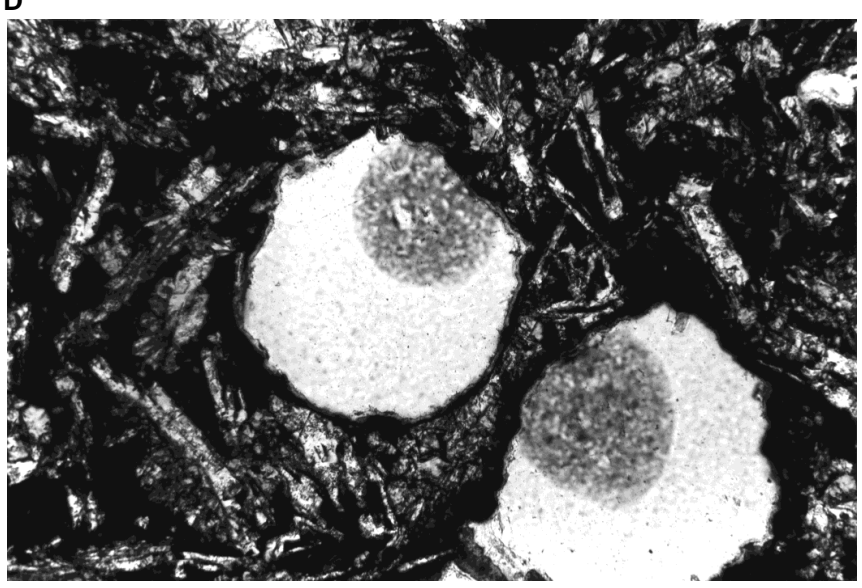

Figure 16. Plane-polarized-light photomicrographs of (A) a completely filled segregation vesicle $(0.4 \mathrm{~mm}$ across $)$, (B) a partially filled segregation vesicle ( 0.4 $\mathrm{mm}$ across), (C) a geopetal infill of a vesicle (0.5 mm across), and (D) two empty gas vesicles ( $0.5 \mathrm{~mm}$ across). All vesicles are from Sample 168-1025C-4R-1 (Piece 4, 19-27 cm). 
A

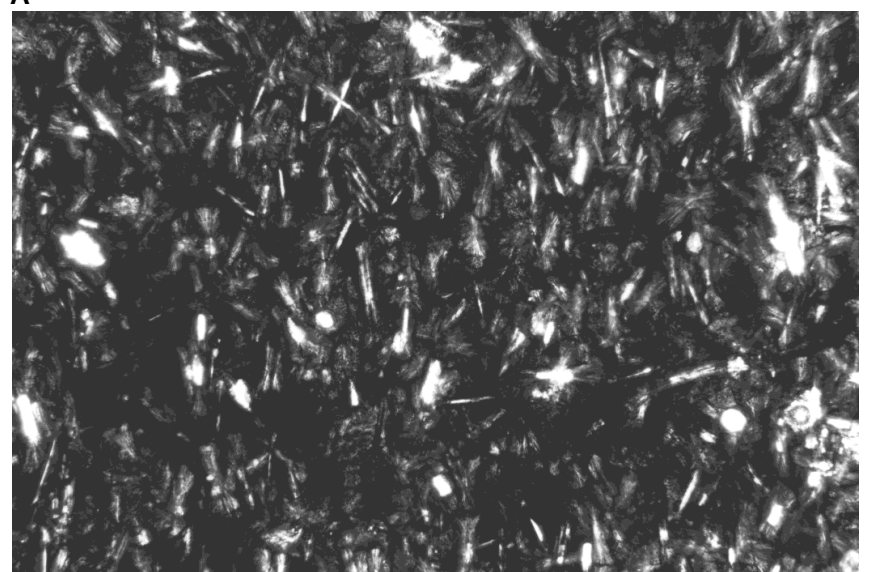

B

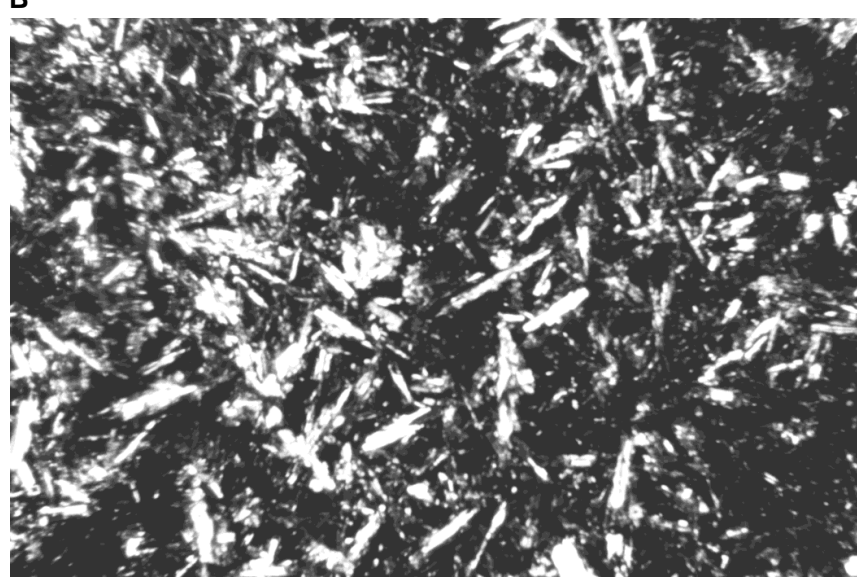

Figure 17. Plane-polarized-light photomicrographs of (A) an aphyric pillow basalt exhibiting a plumose to sheaf-spherulitic texture within the mesostasis (Sample 168-1024B-18X-CC [Piece 3, 9-27 cm]) and (B) an aphyric pillow basalt exhibiting a sheaf-spherulitic to intersertal texture (Sample 1681025B-11X-CC [Piece 2, 28-40 cm], illustrating the mineralogic and textural differences between the two holes. Fields of view $=1.5 \mathrm{~mm}$.

calcite. No fresh olivine occurs within these rocks, although point counting indicates that $1 \%$ olivine was present originally. The pyroxene phenocrysts from Hole 1025B have simple zoning, are closely associated with plagioclase, and represent $1 \%$ of the total rock volume.

The groundmass mineralogy within the sparsely to moderately phyric pillow basalts from both holes is identical, with only slight differences in the relative abundance and grain size of each phase (Fig. $18 \mathrm{~A}, \mathrm{~B})$. Plagioclase $(\leq 0.5 \mathrm{~mm}$; average $=0.2 \mathrm{~mm})$ forms euhedral microlaths, microlites, and quench crystals within the groundmass from both holes, occurring as single crystals, within stellate clusters, or intergrown with microcrystalline pyroxene. Olivine forms 0.2 - to $0.4-\mathrm{mm}$ (average $=0.2-\mathrm{mm}$ ) euhedral microcrysts within samples from both holes. However in core from Hole 1023A, the olivine is fresh $(\leq 4 \%)$, occurring as solitary crystals or associated with groundmass plagioclase, whereas all olivine from Hole 1025B has been replaced by secondary saponite, iddingsite, and/or calcite. (Point counting indicates that the original olivine abundance was $<0.2 \%$.) Pyroxene forms euhedral, equant microcrysts $(\leq 0.1 \mathrm{~mm})$, present in a trace amount (Hole 1023A) to <6\% (Hole 1025B), as solitary crystals, or within granular aggregates of pyroxene + plagioclase + olivine. Trace amounts of primary magmatic pyrite $(\leq 0.05 \mathrm{~mm})$ and chalcopyrite $(\leq 0.02 \mathrm{~mm}$ ) occur within the sparsely to moderately phyric pillow basalts from both holes, present as granular grains within the mesostasis. The mesostasis typically represents between $70 \%$ and $88 \%$ of the sparsely to moderately phyric pillow basalts from both holes, characterized by a subvariolitic plumose texture, which changes with in-
A

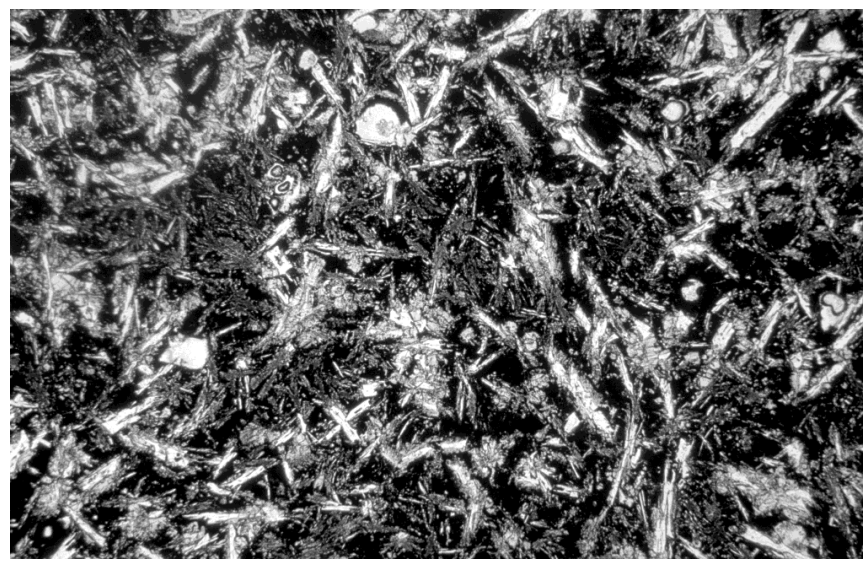

B

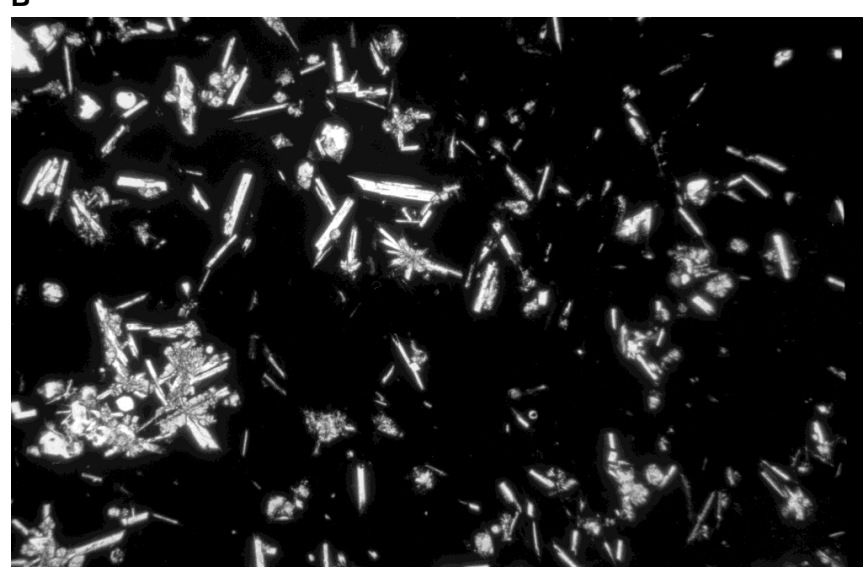

Figure 18. Plane-polarized-light photomicrographs of (A) a moderately phyric pillow basalt (Sample 168-1023A-22X-CC [Piece 4, 34-40 cm]) and (B) a sparsely to moderately phyric pillow basalt (Sample 168-1025B-11X-CC [Piece 3, 28-40 cm]), illustrating the mineralogic and textural differences between the two holes. Fields of view $=5.1 \mathrm{~mm}$.

creasing distance from the chilled margins to a sheaf-spherulitic and intersertal texture. Where a chilled margin is present, it is generally $\leq 1.5 \mathrm{~mm}$ thick and consists of medium to dark brown glass that contains discrete varioles centered around plagioclase and pyroxene microcrysts.

All sparsely to moderately phyric pillow basalts are vesicular, containing $0.6 \%-1.6 \%$ round to ovoid gas vesicles $(0.05-0.2 \mathrm{~mm})$; these are either empty or partially filled by secondary hydrothermal saponite. The pillow basalts from Hole $1023 \mathrm{~A}$ are fresh $(<1 \%$ alteration), whereas those from Hole 1025B are slightly altered $(<2 \%$ alteration).

\section{Igneous Geochemistry}

Bulk-rock major element analyses were conducted on 13 representative samples of massive and pillow basalts from Holes 1024B, 1024C, 1025B, and 1025C (Table 9). All of the analyzed samples are aphyric; thus phenocryst abundance has a marginal effect on the bulk-rock composition.

Substantial problems in the calibration of $\mathrm{Si}$ resulted in $\mathrm{SiO}_{2}$ concentrations being systematically higher (by about $0.8 \%$ ) than the nominal value of $50.02 \%$ for the AII-92-29-1 basalt standard (see "Methods" chapter, this volume). These high values of $\mathrm{SiO}_{2}$ are also apparent for the studied samples, producing oxide totals that are systematically greater than $100 \%$ (on average $\sim 101 \%$ ). We chose to report the analyses without any correction factor. 
Table 9. Geochemical analyses (wt\%) of basalts from Sites 1024 and 1025.

\begin{tabular}{|c|c|c|c|c|c|c|c|c|c|c|c|c|c|}
\hline Hole: & 1024B & $1024 \mathrm{C}$ & $1025 \mathrm{~B}$ & $1025 \mathrm{C}$ & $1025 \mathrm{C}$ & $1025 \mathrm{C}$ & $1025 \mathrm{C}$ & $1025 \mathrm{C}$ & $1025 \mathrm{C}$ & $1025 \mathrm{C}$ & $1025 \mathrm{C}$ & $1025 \mathrm{C}$ & $1025 \mathrm{C}$ \\
\hline Core: & 18X-CC & 1R-1 & $11 X-5$ & 1R-1 & 1R-1 & 1R-2 & 2R-2 & 2R-4 & 4R-1 & 4R-1 & 4R-3 & $5 \mathrm{R}-1$ & $5 \mathrm{R}-2$ \\
\hline Interval $(\mathrm{cm})$ : & $10-37$ & $15-21$ & $40-49$ & $15-20$ & $40-48$ & $38-43$ & $1-7$ & $54-58$ & $19-27$ & $123-125$ & $24-28$ & $38-42$ & $41-45$ \\
\hline Piece: & 1 & 3 & 2 & 3 & 7 & 6 & 1 & 12 & 4 & $16 \mathrm{~A}$ & 1D & 7 & 3 \\
\hline Depth (mbsf): & 167.83 & 173.85 & 97.10 & 106.25 & 106.50 & 107.88 & 113.79 & 117.31 & 128.19 & 129.23 & 131.10 & 137.98 & 139.46 \\
\hline Lithology: & A & A & A & A & A & A & A & A & A & A & A & A & A \\
\hline Alteration (\%): & 0 & 3 & ND & 5 & 1 & 15 & 20 & 10 & 6 & 15 & 15 & 25 & 16 \\
\hline $\mathrm{SiO}_{2}$ & 51.08 & 51.71 & 50.41 & 50.52 & 50.06 & 50.38 & 49.95 & 50.59 & 50.21 & 49.72 & 50.41 & 50.32 & 50.16 \\
\hline $\mathrm{TiO}_{2}$ & 1.45 & 1.60 & 2.60 & 2.43 & 2.48 & 2.50 & 2.53 & 2.58 & 2.50 & 2.53 & 2.50 & 2.70 & 2.65 \\
\hline $\mathrm{Al}_{2} \mathrm{O}_{3}$ & 14.27 & 14.97 & 12.96 & 13.29 & 13.19 & 12.99 & 12.84 & 13.12 & 12.69 & 12.60 & 13.13 & 12.59 & 13.12 \\
\hline $\mathrm{Fe}_{2} \mathrm{O}_{3} *$ & 10.34 & 9.97 & 15.74 & 14.80 & 15.26 & 14.50 & 15.03 & 15.10 & 15.55 & 15.32 & 15.05 & 15.74 & 15.91 \\
\hline $\mathrm{MnO}$ & 0.18 & 0.16 & 0.24 & 0.19 & 0.21 & 0.22 & 0.22 & 0.22 & 0.21 & 0.21 & 0.19 & 0.21 & 0.21 \\
\hline $\mathrm{MgO}$ & 7.17 & 7.47 & 6.00 & 6.25 & 6.19 & 6.42 & 6.41 & 6.42 & 6.36 & 6.47 & 6.49 & 6.48 & 6.40 \\
\hline $\mathrm{CaO}$ & 12.06 & 12.21 & 10.54 & 10.87 & 10.64 & 10.43 & 10.58 & 10.39 & 10.71 & 10.47 & 10.47 & 10.04 & 10.11 \\
\hline $\mathrm{Na}_{2} \mathrm{O}$ & 2.64 & 3.08 & 2.63 & 2.71 & 2.71 & 2.82 & 2.83 & 2.87 & 2.74 & 2.79 & 2.77 & 3.02 & 2.79 \\
\hline $\mathrm{K}_{2} \mathrm{O}$ & 0.20 & 0.10 & 0.21 & 0.23 & 0.20 & 0.14 & 0.16 & 0.14 & 0.19 & 0.16 & 0.16 & 0.09 & 0.14 \\
\hline $\mathrm{P}_{2} \mathrm{O}_{5}$ & 0.13 & 0.13 & 0.24 & 0.23 & 0.24 & 0.23 & 0.23 & 0.24 & 0.24 & 0.23 & 0.23 & 0.25 & 0.25 \\
\hline Total & 99.53 & 101.38 & 101.59 & 101.52 & 101.18 & 100.57 & 100.78 & 101.67 & 101.40 & 100.49 & 101.40 & 101.44 & 101.74 \\
\hline LOI & -0.43 & 0.27 & 1.16 & 0.00 & -0.27 & 0.00 & 0.17 & 0.07 & 0.07 & 0.20 & 0.40 & 0.10 & -0.03 \\
\hline $\mathrm{H}_{2} \mathrm{O}$ & 0.20 & 0.80 & 0.58 & 0.87 & 0.88 & 0.70 & 1.06 & 0.91 & 1.10 & 0.83 & 1.09 & 0.88 & 0.84 \\
\hline $\mathrm{CO}_{2}$ & 0.04 & ND & 0.02 & 0.09 & 0.05 & 0.22 & 0.37 & 0.20 & 0.19 & 0.09 & ND & 1.11 & 0.15 \\
\hline $\mathrm{S}$ & 0.10 & 0.04 & 0.09 & 0.11 & 0.09 & 0.13 & 0.11 & 0.10 & 0.10 & 0.10 & 0.10 & 0.12 & 0.12 \\
\hline Mg\# & 60.40 & 62.23 & 45.64 & 48.18 & 47.17 & 49.36 & 48.40 & 48.34 & 47.37 & 48.16 & 48.67 & 47.52 & 46.96 \\
\hline $\mathrm{K} / \mathrm{Ti}$ & 0.19 & 0.09 & 0.11 & 0.13 & 0.11 & 0.07 & 0.09 & 0.07 & 0.10 & 0.09 & 0.09 & 0.05 & 0.07 \\
\hline $\mathrm{K} / \mathrm{P}$ & 3.00 & 1.46 & 1.70 & 1.91 & 1.65 & 1.10 & 1.32 & 1.08 & 1.48 & 1.29 & 1.31 & 0.70 & 1.05 \\
\hline
\end{tabular}

Notes: $\mathrm{A}=$ aphyric basalt. $\mathrm{ND}=$ not detected. $\mathrm{LOI}=$ loss on ignition. $\mathrm{Fe}_{2} \mathrm{O}_{3} *=$ total amount of iron expressed as $\mathrm{Fe}_{2} \mathrm{O}_{3} . \mathrm{Mg} \#=100 \times \mathrm{Mg} /\left(\mathrm{Mg}+\mathrm{Fe}{ }^{2+}\right)$, where $\mathrm{Fe}{ }^{2+}=0.9 \times \mathrm{Fe}$ total .

\section{Results}

Variation diagrams (Fig. 19) show that the two basalts from Site 1024 are similar to each other and that all of the basalts from Site 1025 form a relatively homogeneous chemical group that is quite distinct from the Site 1024 basalts. The two aphyric pillow basalts from Site 1024 are low-potassium tholeiites that have compositions similar to the pillow basalts from Sites 1026 and 1027 (see the "Rough Basement Transect" chapter, this volume). At Site 1025, massive basalts from the various subunits of Hole $1025 \mathrm{C}$, as well as the one analyzed basalt from Hole 1025B, are distinguished by their relatively high $\mathrm{TiO}_{2}(2.4-2.7 \mathrm{wt} \%), \mathrm{Fe}_{2} \mathrm{O}_{3}(14.8-15.9 \mathrm{wt} \%), \mathrm{MnO}, \mathrm{P}_{2} \mathrm{O}_{5}, \mathrm{H}_{2} \mathrm{O}$, and $\mathrm{S}$, and low $\mathrm{Al}_{2} \mathrm{O}_{3}(12.6-13.2 \mathrm{wt} \%), \mathrm{MgO}(6.0-6.5 \mathrm{wt} \%)$ and $\mathrm{Mg \#}$ (45.6-48.9). High $\mathrm{TiO}_{2}$ and $\mathrm{Fe}_{2} \mathrm{O}_{3}$ are characteristic of ferrobasalts, and the massive basalts from Site 1025 bear a strong chemical resemblance to other oceanic ferrobasalts such as those drilled during Leg 54 on the East Pacific Rise at $9^{\circ} \mathrm{N}$ (Hekinian and Morel, 1980; Natland, 1980). Consequently, the Site $1025 \mathrm{C}$ basalts are classified as oceanic ferrobasalts.

\section{Alteration Effects}

The primary composition of basalts from Sites 1024 and 1025 may be modified by precipitation of clay and other secondary minerals in veins and vesicles or by the replacement of phenocrysts and groundmass. Because the abundance of secondary minerals is generally low at Site 1024 and variable at Site 1025 (see Table 10), bulk geochemical effects caused by alteration may be less significant at Site 1024. Similarly, secondary alteration at the Hydrothermal Transition sites is generally lower than that determined for the Rough Basement sites (see "Rough Basement Transect" chapter, this volume). Consistent with these constraints, basalts from the Hydrothermal Transition sites have generally lower $\mathrm{H}_{2} \mathrm{O}$ and $\mathrm{CO}_{2}$ values relative to the Rough Basement sites. Sulfur values are higher at the Hydrothermal Transition sites, perhaps consistent with the greater abundance of primary opaque sulfide minerals noted in the massive basalts from Hole 1025C.

\section{Basement Alteration}

Secondary alteration with variable intensity affects all igneous rocks recovered from Sites 1023, 1024, and 1025. Secondary miner- als are found in four distinct modes of occurrence: (1) vesicle or cavity linings or fillings; (2) coatings, fracture fillings, and veins; (3) replacement of phenocrysts and microphenocrysts; and (4) patches within mesostasis. In the following sections, the alteration minerals will be described, as well as specific alteration characteristics of the rocks such as the alteration intensity, halos, veins, and the spatial variability of hydrothermal alteration between various units at Sites 1023,1024 , and 1025 .

\section{Secondary Minerals}

The following secondary minerals were identified by means of hand specimen observation, optical characteristics in thin section, and powder X-ray diffraction (XRD): clay minerals, iddingsite, carbonates (aragonite and calcite), zeolites, talc, quartz, and sulfides (Table 10). Table 11 summarizes the results of shipboard XRD studies.

\section{Clay Minerals}

Clay minerals are ubiquitous and are the most abundant secondary products, present in all four modes discussed previously (in vesicles, in veins, as replacing minerals, and in mesostasis). Clay minerals were determined optically following the criteria of Honnorez et al. (1983) and Laverne et al. (1996). X-ray diffractograms, including those of air-dried and glycolated powder mounts, confirm the presence of trioctahedral smectite (saponite, $\mathrm{d}_{060}=1.53 \AA$ ).

Saponite is the most common clay, and it has been identified at all Hydrothermal Transition sites (Table 10). It occurs as cryptocrystalline granular or fibrous aggregates, varying in color from olive green to green, greenish blue, and pale blue in hand specimens and from pale brown (most commonly) to yellowish, brownish green and olive green in thin section. In weakly altered samples, saponite lines vesicles in layers as thin as $10 \mu \mathrm{m}$, whereas in more heavily altered samples, it may fill vesicles completely. Saponite is the most common mineral observed to alter olivine phenocrysts or microphenocrysts, occurring alone or with other minerals. Saponite occurs both as a vein mineral, alone or with other minerals, and as a replacement of mesostasis.

Celadonite (or protoceladonite[?]) forms cryptocrystalline granular or fibrous aggregates and is bright green in thin section. It forms vesicle linings or complete fillings, and veins, and is commonly intergrown with other minerals (e.g., saponite and iddingsite). Celado- 

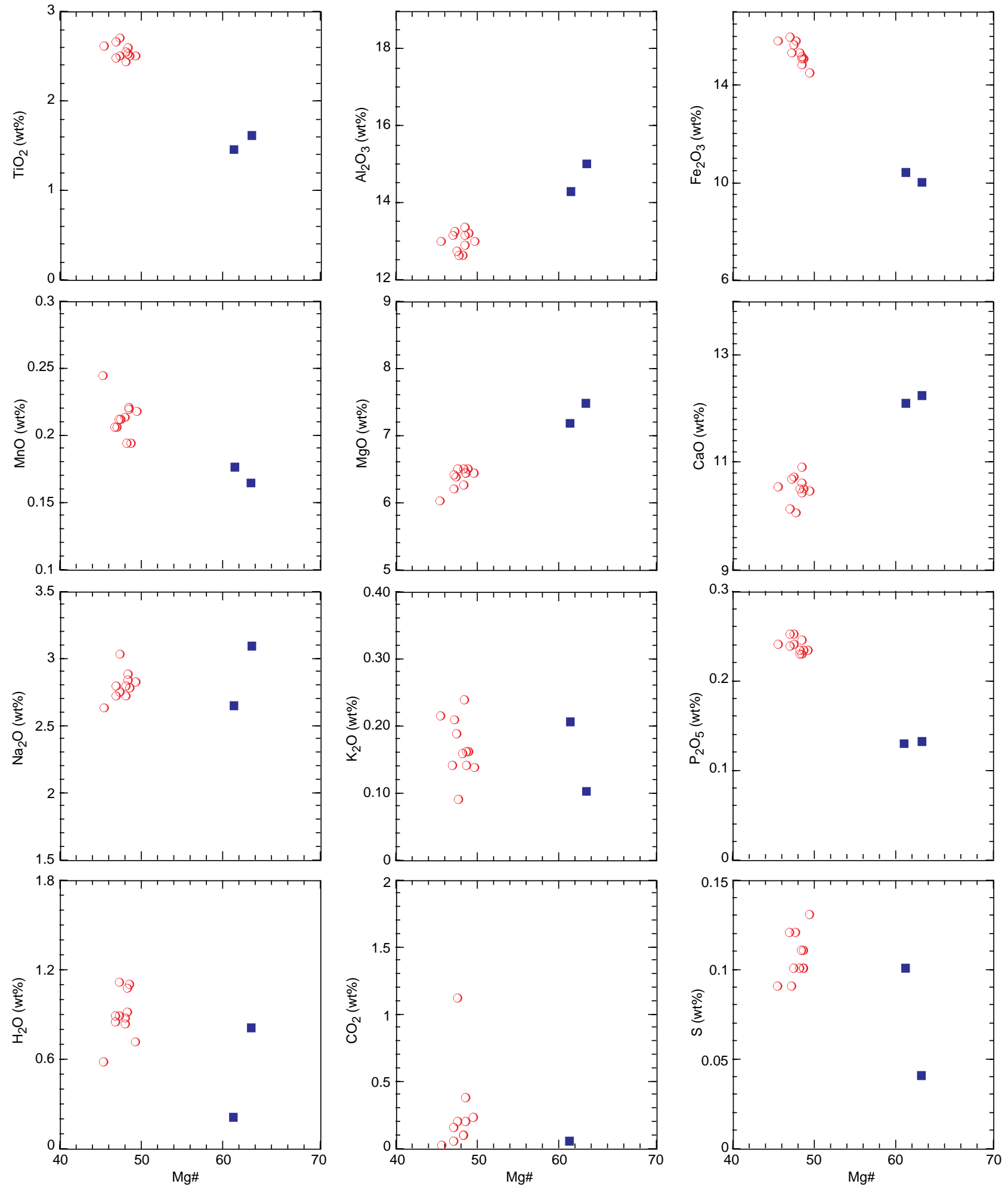

Figure 19. Results of X-ray fluorescence analyses of basaltic rocks from the Hydrothermal Transistion sites. Each figure represents the weight percent of an oxide, or an elemental ratio, plotted against the $\mathrm{Mg} \#$ [where $\mathrm{Mg} \#=100 \times \mathrm{MgO} /(\mathrm{FeO}+\mathrm{MgO})$, and $\mathrm{FeO}=0.9 \times\left(\mathrm{Fe}_{2} \mathrm{O}_{3} *\right)$ ]. Solid squares $=\mathrm{Holes} 1024 \mathrm{~B}$ and $1024 \mathrm{C}$; open circles $=$ Holes $1025 \mathrm{~B}$ and $1025 \mathrm{C}$. 
nite is very restricted in occurrence (Table 10), and it is characteristic (along with iddingsite) of an oxidative style of alteration (Laverne et al., 1996; Teagle et al., 1996; see discussion below).

Chlorite/smectite forms as minor fibrous grains, with saponite, after olivine. It is distinguished by marked pleochroism combined with low birefringence. It is recognized in only one thin section (Table $12)$.

\section{Iddingsite}

Iddingsite is a mixture of clay mineral(s) and Fe-oxyhydroxide and has a characteristic red-orange or reddish brown color both in hand specimen and thin section. It occurs as irregular patches, replacing mafic minerals or lining/filling vesicles and veins, and is often associated with celadonite (Table 10).

Table 10. Summary of secondary minerals observed in thin sections of basaltic rocks from the Hydrothermal Transition sites.

\begin{tabular}{|c|c|c|c|c|c|c|c|c|c|c|c|}
\hline Sample & Structure & $\begin{array}{l}\text { Fresh } \\
\text { glass }\end{array}$ & Saponite & Carbonate & Celadonite & Iddingsite & Pyrite & Talc & $\begin{array}{l}\text { Chlorite/ } \\
\text { Smectite }\end{array}$ & Zeolites & Quartz \\
\hline $\begin{array}{l}\text { 1023A-22X-CC (Piece 4, 34-40 cm) } \\
\text { 1023A-22X-CC (Piece 6, 34-40 cm) }\end{array}$ & $\begin{array}{l}\text { Pillow basalt } \\
\text { Pillow basalt }\end{array}$ & $\begin{array}{l}++ \\
++\end{array}$ & $\begin{array}{l}\operatorname{Tr} \\
\operatorname{Tr} ?\end{array}$ & & & & $\begin{array}{l}\operatorname{Tr} \\
\operatorname{Tr}\end{array}$ & & & & \\
\hline $\begin{array}{l}\text { 1024B-18X-CC (Piece 3, 9-27 cm) } \\
\text { 1024B-18X-CC (Piece 12, 9-27 cm) }\end{array}$ & $\begin{array}{l}\text { Pillow basalt } \\
\text { Pillow basalt }\end{array}$ & $\begin{array}{l}++ \\
+\end{array}$ & $\begin{array}{l}+ \\
\operatorname{Tr}\end{array}$ & & $\begin{array}{l}\operatorname{Tr} \\
\operatorname{Tr}\end{array}$ & $\begin{array}{l}\operatorname{Tr} \\
\operatorname{Tr}\end{array}$ & $\begin{array}{l}\operatorname{Tr} \\
\operatorname{Tr}\end{array}$ & & & & \\
\hline $\begin{array}{l}\text { 1024C-1R-1 (Piece 1, 0-8 cm) } \\
\text { 1024C-1R-1 (Piece 2, 8-15 cm) }\end{array}$ & $\begin{array}{l}\text { Pillow basalt } \\
\text { Pillow basalt }\end{array}$ & & $\begin{array}{l}+ \\
+\end{array}$ & & $\begin{array}{l}++ \\
++\end{array}$ & $\begin{array}{l}+ \\
+\end{array}$ & $\begin{array}{l}\operatorname{Tr} \\
\operatorname{Tr}\end{array}$ & & & & \\
\hline $\begin{array}{l}\text { 1025B-11X-CC (Piece 2, 28-40 cm) } \\
\text { 1025B-11X-CC (Piece 3, 28-40 cm) }\end{array}$ & $\begin{array}{l}\text { Pillow basalt } \\
\text { Pillow basalt }\end{array}$ & + & $\begin{array}{l}++ \\
++\end{array}$ & $\operatorname{Tr}$ & $\stackrel{+}{\operatorname{Tr}}$ & $\stackrel{+}{\operatorname{Tr}}$ & $\begin{array}{l}\operatorname{Tr} \\
\operatorname{Tr}\end{array}$ & & & & \\
\hline $\begin{array}{l}\text { 1025C-1R-1 (Piece 3, 15-20 cm) } \\
\text { 1025C-1R-1 (Piece 8, 48-59 cm) } \\
\text { 1025C-1R-2 (Piece 3, 16-20 cm) } \\
\text { 1025C-2R-1 (Piece 17, 143-147 cm) } \\
\text { 1025C-2R-2 (Piece 11B, 139-142 cm) } \\
\text { 1025C-2R-4 (Piece 12, } 54-58 \mathrm{~cm} \text { ) } \\
\text { 1025C-3R-1 (Piece 5, 19-27 cm) } \\
\text { 1025C-3R-1 (Piece 7, 30-34 cm) } \\
\text { 1025C-4R-1 (Piece 4, } 19-27 \mathrm{~cm}) \\
\text { 1025C-4R-1 (Piece 16A, 123-125 cm) } \\
\text { 1025C-4R-3 (Piece 1D, 24-28 cm) } \\
\text { 1025C-5R-1 (Piece 7, 38-42 cm) } \\
\text { 1025C-5R-2 (Piece 3, 41-45 cm) }\end{array}$ & $\begin{array}{l}\text { Massive basalt } \\
\text { Massive basalt } \\
\text { Massive basalt } \\
\text { Massive basalt } \\
\text { Massive basalt } \\
\text { Massive basalt } \\
\text { Massive basalt } \\
\text { Massive basalt } \\
\text { Massive basalt } \\
\text { Massive basalt } \\
\text { Massive basalt } \\
\text { Massive basalt } \\
\text { Massive basalt }\end{array}$ & & $\begin{array}{l}+++ \\
+ \\
+++ \\
+++ \\
+++ \\
+++ \\
++ \\
++ \\
+++ \\
+++ \\
+++ \\
+++ \\
+++\end{array}$ & $\begin{array}{l}\mathrm{Tr} \\
\mathrm{Tr} \\
\mathrm{Tr}\end{array}$ & & $\operatorname{Tr}$ & $\begin{array}{l}\mathrm{Tr} \\
\mathrm{Tr} \\
\mathrm{Tr} \\
\mathrm{Tr} \\
\mathrm{Tr} \\
\mathrm{Tr} \\
\mathrm{Tr} \\
\mathrm{Tr} \\
\mathrm{Tr} \\
\mathrm{Tr} \\
\mathrm{Tr} \\
\mathrm{Tr} \\
\mathrm{Tr}\end{array}$ & $\operatorname{Tr}$ & $\operatorname{Tr} ?$ & $\begin{array}{l}+ \\
\mathrm{Tr} \\
\mathrm{Tr}\end{array}$ & $\operatorname{Tr}$ \\
\hline
\end{tabular}

Note: $\operatorname{Tr} ?=$ possible trace amount, $\operatorname{Tr}=$ trace amount, $+=<1 \%,++=1 \%-5 \%$, and $+++=>5 \%$.

Table 11. Results of shipboard X-ray diffraction studies performed on secondary minerals from the Hydrothermal Transition Transect sites.

\begin{tabular}{llccll}
\hline Sample & $(060)^{*}$ & $(001)^{*}$ & $(001)-G L Y *$ & Description & Mineral \\
\hline 168-1023A-22X-CC, 35-41 cm & ND & 13.5 & 17.3 & Green clay & Smectite \\
168-1025C-1R-2 (Piece 16, 95-103 cm) & 1.529 & 13.2 & 16.5 & Green clay & Trioctahedral smectite \\
168-1025C-1R-3 (Piece 8, 44-48 cm) & 1.528 & 12.6 & 17.2 & Green clay & Trioctahedral smectite \\
168-1025C-2R-3 (Piece 7, 73-82 cm) & NA & NA & NA & White vein & Aragonite + trace calcite \\
$168-1025$ C-5R-1 (Piece 5, 25-32 cm) & NA & NA & NA & White vein & Talc + minor clay + unidentified \\
\hline
\end{tabular}

Notes: * =d-spacing $(\AA)$, and GLY = glycolated sample. ND = not determined, and NA = not applicable.

Table 12. Modal point-count data for secondary minerals in thin sections from Sites 1023, 1024 , and 1025.

\begin{tabular}{|c|c|c|c|c|c|c|c|c|c|c|c|}
\hline Sample & Structure & $\begin{array}{c}\text { Total } \\
\text { alteration } \\
(\%)\end{array}$ & $\begin{array}{c}\text { Saponite } \\
(\%)\end{array}$ & $\begin{array}{c}\text { Carbonate } \\
(\%)\end{array}$ & $\begin{array}{c}\text { Celadonite } \\
(\%)\end{array}$ & $\begin{array}{c}\text { Iddingsite } \\
(\%)\end{array}$ & $\begin{array}{c}\text { Pyrite } \\
(\%)\end{array}$ & $\begin{array}{l}\text { Talc } \\
(\%)\end{array}$ & $\begin{array}{c}\text { Chlorite/ } \\
\text { Smectite } \\
(\%)\end{array}$ & $\begin{array}{c}\text { Zeolite } \\
(\%)\end{array}$ & $\begin{array}{c}\text { Quartz } \\
(\%)\end{array}$ \\
\hline 1023A-22X-CC (Piece 4, 34-40 cm) & Pillow basalt & $\operatorname{Tr}$ & $\operatorname{Tr}$ & 0 & 0 & 0 & $\operatorname{Tr}$ & 0 & 0 & 0 & 0 \\
\hline 1023A-22X-CC (Piece 6, 34-40 cm) & Pillow basalt & $\operatorname{Tr}$ & $\operatorname{Tr}$ & 0 & 0 & 0 & $\operatorname{Tr}$ & 0 & 0 & 0 & 0 \\
\hline 1024B-18X-CC (Piece 3, 9-27 cm) & Pillow basalt & 0.4 & 0.4 & 0 & $\operatorname{Tr}$ & $\operatorname{Tr}$ & $\operatorname{Tr}$ & 0 & 0 & 0 & 0 \\
\hline 1024B-18X-CC (Piece 12, 9-27 cm) & Pillow basalt & $\operatorname{Tr}$ & $\operatorname{Tr}$ & 0 & $\operatorname{Tr}$ & $\operatorname{Tr}$ & $\operatorname{Tr}$ & 0 & 0 & 0 & 0 \\
\hline 1024C-1R-1 (Piece 1, 0-8 cm) & Pillow basalt & 1.8 & 0.2 & 0 & 1 & 0.6 & $\operatorname{Tr}$ & 0 & 0 & 0 & 0 \\
\hline 1024C-1R-1 (Piece 2, 8-15 cm) & Pillow basalt & 2.9 & 0.2 & 0 & 2.5 & 0.2 & $\operatorname{Tr}$ & 0 & 0 & 0 & 0 \\
\hline 1025B-11X-CC (Piece 2, 28-40 cm) & Pillow basalt & 2 & 1 & 0 & 0.5 & 0.5 & $\operatorname{Tr}$ & 0 & 0 & 0 & 0 \\
\hline 1025B-11X-CC (Piece 3, 28-40 cm) & Pillow basalt & 1.2 & 1.2 & $\operatorname{Tr}$ & $\operatorname{Tr}$ & $\operatorname{Tr}$ & $\operatorname{Tr}$ & 0 & 0 & 0 & 0 \\
\hline 1025C-1R-1 (Piece 3, 15-20 cm) & Massive basalt & 5.2 & 5.2 & 0 & 0 & 0 & $\operatorname{Tr}$ & 0 & 0 & 0 & 0 \\
\hline 1025C-1R-1 (Piece 8, 48-59 cm) & Massive basalt & 1.3 & 1.3 & 0 & 0 & 0 & $\operatorname{Tr}$ & 0 & 0 & 0 & 0 \\
\hline $1025 \mathrm{C}-1 \mathrm{R}-2$ (Piece $3,16-20 \mathrm{~cm})$ & Massive basalt & 15.1 & 15.1 & 0 & 0 & 0 & $\operatorname{Tr}$ & 0 & 0 & $\operatorname{Tr}$ & 0 \\
\hline $1025 \mathrm{C}-2 \mathrm{R}-1$ (Piece $17,143-147 \mathrm{~cm})$ & Massive basalt & 19.7 & 19.7 & 0 & 0 & 0 & $\operatorname{Tr}$ & 0 & 0 & 0 & 0 \\
\hline $1025 \mathrm{C}-2 \mathrm{R}-2$ (Piece $11 \mathrm{~B}, 139-142 \mathrm{~cm}$ ) & Massive basalt & 22.7 & 22.7 & $\operatorname{Tr}$ & 0 & $\operatorname{Tr}$ & $\operatorname{Tr}$ & 0 & 0 & 0 & $\operatorname{Tr}$ \\
\hline $1025 \mathrm{C}-2 \mathrm{R}-4$ (Piece $12,54-58 \mathrm{~cm})$ & Massive basalt & 10 & 10 & $\mathrm{Tr}$ & 0 & 0 & $\mathrm{Tr}$ & 0 & 0 & $\operatorname{Tr}$ & 0 \\
\hline $1025 \mathrm{C}-3 \mathrm{R}-1$ (Piece $5,19-27 \mathrm{~cm})$ & Massive basalt & 2.2 & 2.2 & 0 & 0 & 0 & $\operatorname{Tr}$ & 0 & 0 & 0 & 0 \\
\hline 1025C-3R-1 (Piece 7, 30-34 cm) & Massive basalt & 1.4 & 1.4 & $\operatorname{Tr}$ & 0 & 0 & $\operatorname{Tr}$ & 0 & 0 & 0 & 0 \\
\hline 1025C-4R-1 (Piece 4, 19-27 cm) & Massive basalt & 5.8 & 5.8 & 0 & 0 & 0 & $\mathrm{Tr}$ & 0 & 0 & 0 & 0 \\
\hline $1025 \mathrm{C}-4 \mathrm{R}-1$ (Piece 16A, $123-125 \mathrm{~cm}$ ) & Massive basalt & 15.3 & 15.3 & 0 & 0 & 0 & $\operatorname{Tr}$ & 0 & 0 & 0 & 0 \\
\hline $1025 \mathrm{C}-4 \mathrm{R}-3$ (Piece 1D, 24-28 cm) & Massive basalt & 14.5 & 14.1 & $\operatorname{Tr}$ & 0 & 0 & $\mathrm{Tr}$ & 0 & 0 & 0.4 & 0 \\
\hline $1025 \mathrm{C}-5 \mathrm{R}-1($ Piece $7,38-42 \mathrm{~cm})$ & Massive basalt & 24.5 & 24.5 & 0 & 0 & 0 & $\mathrm{Tr}$ & $\mathrm{Tr}$ & $\operatorname{Tr} ?$ & $\mathrm{Tr}$ & 0 \\
\hline 1025C-5R-2 (Piece $3,41-45 \mathrm{~cm}$ ) & Massive basalt & 16 & 16 & $\mathrm{Tr}$ & 0 & 0 & $\mathrm{Tr}$ & 0 & 0 & $\mathrm{Tr}$ & 0 \\
\hline
\end{tabular}

Note: $\operatorname{Tr}=$ trace amount, and $\operatorname{Tr} ?=$ possible trace amount. 


\section{Calcium Carbonate}

Calcium carbonate was recognized using optical petrography and XRD. The polymorphs, aragonite and calcite, could not always be distinguished because of the fine grain sizes and paucity of carbonate in thin sections. Carbonate was present only at Site 1025, often with saponite, as accessory grains replacing olivine microphenocrysts, as individual subhedral crystals (aragonite) projecting inside some vesicles, and in veins attached to external rock surfaces.

\section{Sulfide Minerals}

Pyrite is ubiquitous at all three Hydrothermal Transition sites (Table 10). Present as a common trace constituent, pyrite (together with smaller amounts of pyrrhotite and chalcopyrite) forms fine anhedral grains in cryptocrystalline mesostasis, as well as rounded globular grains in mesostasis, in glass and enclosed in microlites. This type of pyrite may be primary igneous or secondary.

Secondary sulfides occur as fine grains partially coating sample pieces, fine grains within altered mesostasis, and as veinlets and vesicle linings, commonly associated with saponite. Some interstitial sulfides within groundmass, including pyrite, pyrrhotite and chalcopyrite, are localized along the inner edges of alteration halos.

\section{Talc, Quartz, and Zeolites}

Talc occurs as a replacement (with saponite) of olivine, as well as fibrous aggregates that form veins. Its identification was confirmed by XRD. Quartz forms three small veinlets in one section of a core from Hole 1025C (Table 10). The mineral varies from cryptocrystalline chalcedony to subhedral drusy crystals that exhibit the uniaxial optics of $\alpha$-quartz. Trace amounts of zeolite are present in vesicles and in mesostasis.

\section{Alteration Intensity}

The amount of alteration determined by point counting the secondary minerals in thin sections varies from $0 \%$ to $24.5 \%$ (with modes around $1 \%$ and $15 \%$; Table 12, Fig. 20.). Local extremes in alteration intensity occur, from some glass rims that appear practically unaltered to centimeter-scale patches of intense alteration $(40 \%-$ $50 \%$ ) associated with fractures or veins.

The state of olivine is a sensitive petrographic indicator of alteration intensity, as it is typically the first and only crystalline magmatic phase to be replaced. Clinopyroxene, by contrast, is typically unaltered, and plagioclase is rarely altered partially to saponite.

Fresh, unaltered olivine is present in the weakly altered pillow basalts recovered from Site 1023A. Olivines at Site 1024 are variably altered, with fresh relict olivine common. In contrast, Site 1025 olivine is completely altered to saponite with accessory carbonate and/or talc, with the exception of some fine-grained hyalopilitic rocks that have altered olivines with some relict fresh cores. This is consistent with the overall increased degree of alteration and hydration of the Site 1025 basalts relative to the other Hydrothermal Transition basalts.

\section{Alteration Halos}

Alteration halos at the Hydrothermal Transition sites are common at Site 1024 and rare at Site 1025. They are reported in the alteration $\log$ (Appendix C on CD-ROM, back pocket). These halos, 1-5 mm wide, appear in hand specimen as dark borders on rock pieces that may be stained with orange (Fig. 21). Halos are present primarily in pillow basalts; they are rare in the massive basalt of Hole $1025 \mathrm{C}$.

Alteration halos are distinguished by the presence of completely filled vesicles, in contrast to empty or saponite-lined vesicles in the gray, non-halo portion of the rock. The vesicle filling material is clay, commonly iddingsite and/or celadonite. The inner edge of halos is

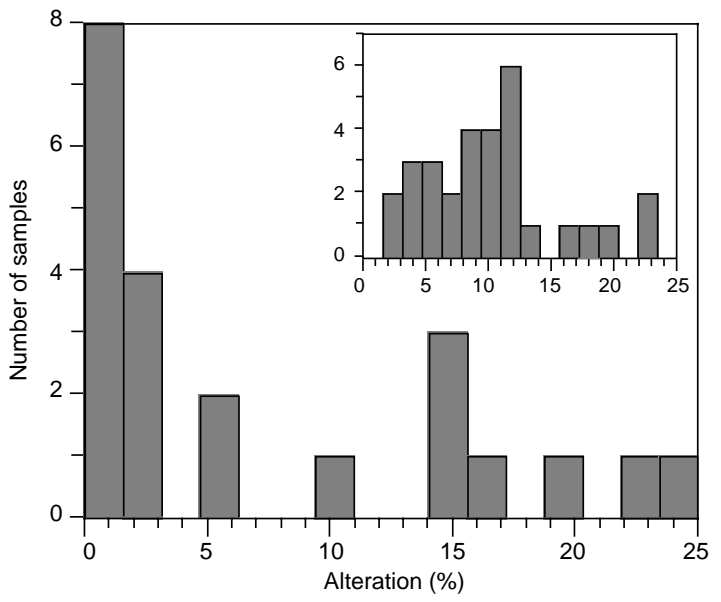

Figure 20. Histogram showing the modal proportion of secondary minerals in thin sections from basaltic rocks from the Hydrothermal Transition sites. The inset shows a corresponding histogram constructed for the Rough Basement sites (see the "Rough Basement Transect" chapter, this volume).

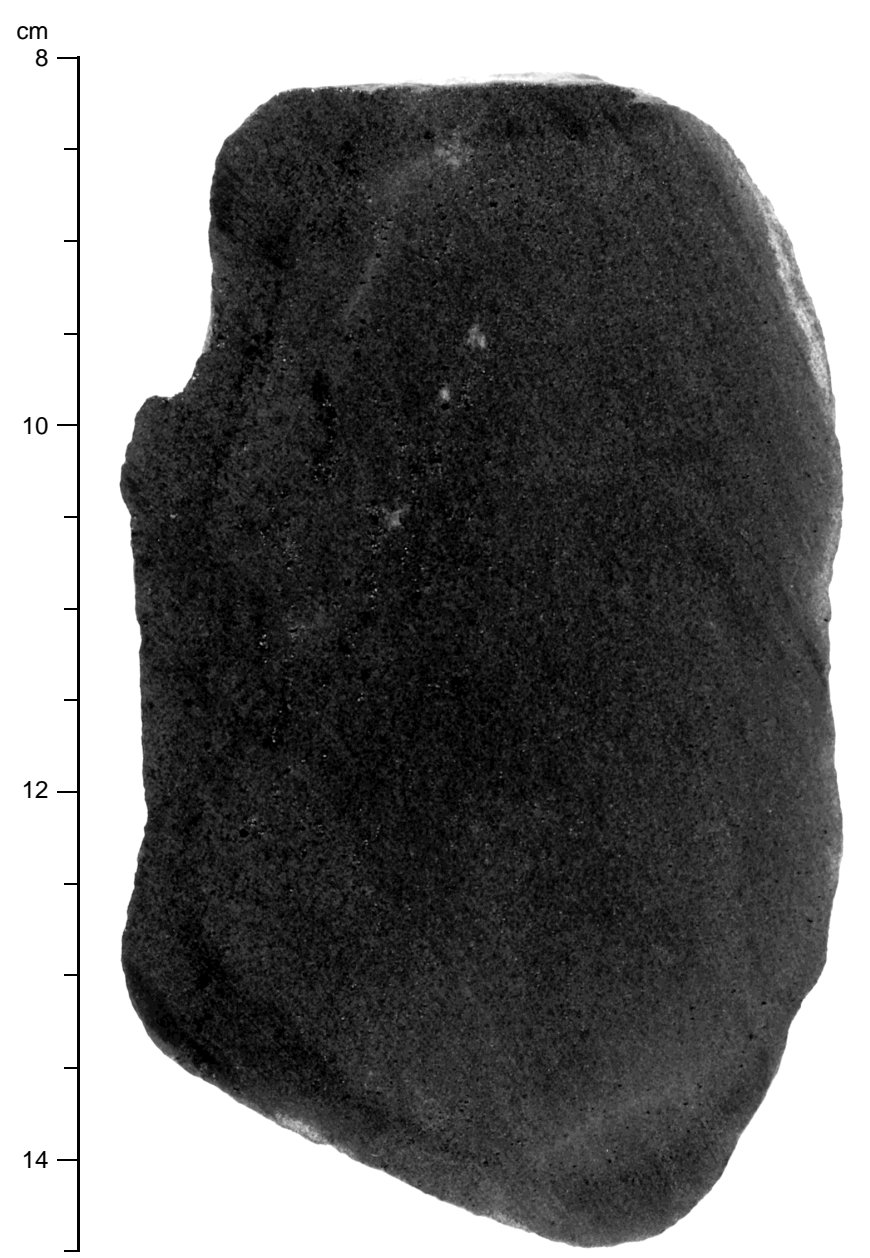

Figure 21. Close-up photograph of basalt with an alteration halo (Sample 168-1024C-1R-1 [Piece 2, 8-14.5 cm]). 
A

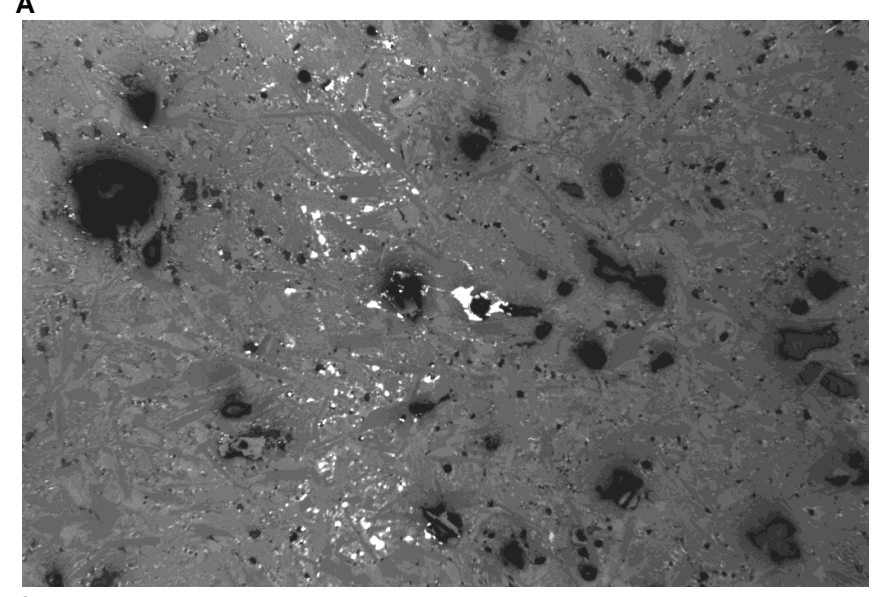

C

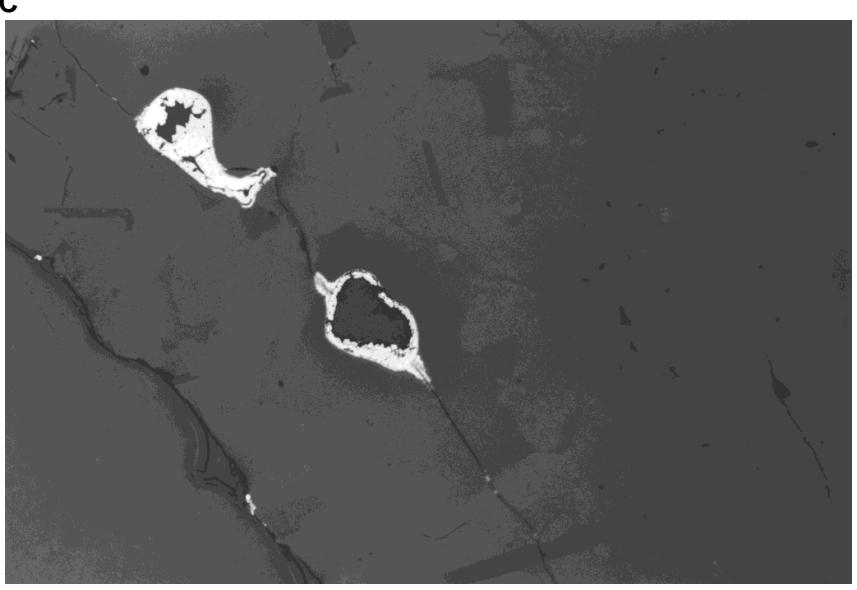

B

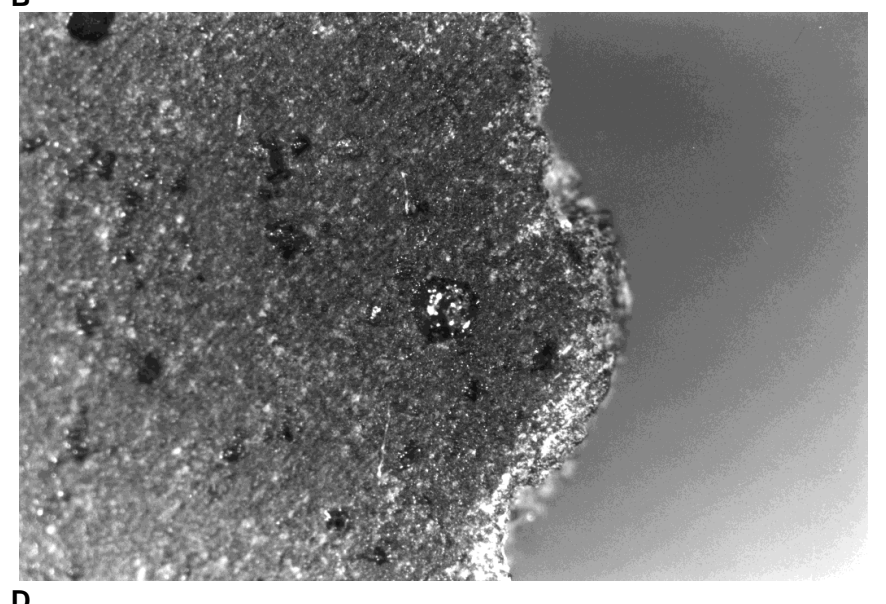

D

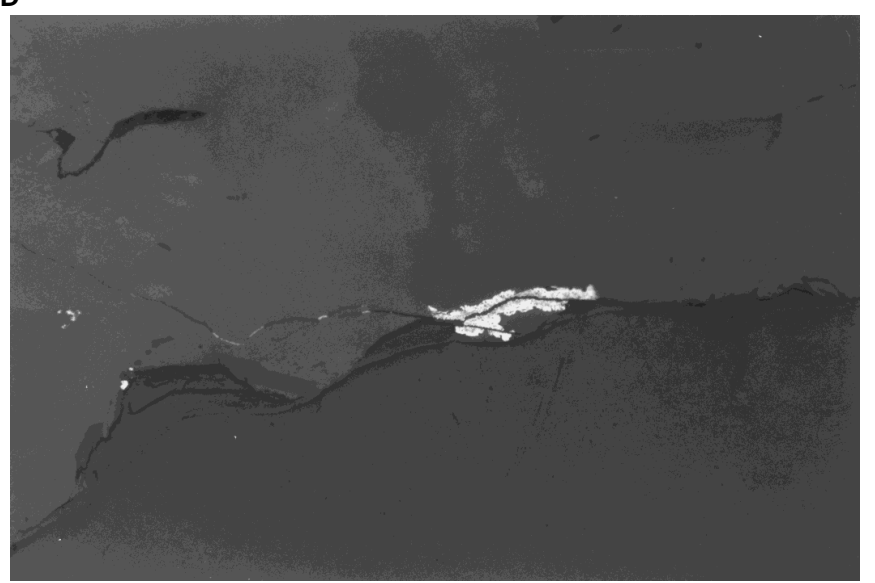

Figure 22. Photomicrographs illustrating various modes of occurrence of secondary sulfide minerals. A. Reflected-light photomicrograph showing a 0.4-mmwide band of interstitial sulfides along the leading edge of an oxidative alteration halo (Sample 168-1024B-18X-CC [Piece 12, 9-27 cm]). B. Binocular microscope photograph of a sawed surface revealing a vesicle lined by drusy pyrite (Sample 168-1025B-11X-CC [Piece $2,35-37 \mathrm{~cm}]$ ). Vesicle is $0.8 \mathrm{~mm}$ in diameter. C. Reflected-light photomicrograph of pyrite-lined vesicles in glass (Sample 168-1025B-11X-CC [Piece 3, 38-39 cm]). Vesicles are about 0.12 mm across (short dimension). D. Reflected-light photomicrograph of pyrite replacement of glass along a microfracture (Sample 168-1025B-11X-CC [Piece 3, 38-39 cm]). Pyrite mass is $0.14 \mathrm{~mm}$ long.

sharply defined; vesicles only tenths of a millimeter apart may be completely filled on the halo side and completely empty on the fresh rock side. In several instances, the leading edge of the alteration halo is also marked by a concentration of fine granular sulfides (intergrowths of pyrite and pyrrhotite, with trace chalcopyrite) on the inner side of the edge (Fig. 22A).

\section{Vesicle Fillings}

All vesicles are either lined or completely filled by secondary minerals. Most commonly, vesicles are lined by one or more texturally and mineralogically different clays, with or without one of the following accessory minerals: pyrite, aragonite, or zeolite. The type and sequence of filling is interpreted as a sensitive record of successive changes in the chemical microenvironments affecting the host rock. Vesicle fillings vary systematically depending on whether the vesicles are in the alteration halos, transitional zones, or the gray rock interiors.

Pillow basalts from Site 1023 contain vesicles that are simply lined by saponite. In the slightly more altered pillow basalts from Site 1024, most vesicles have saponite linings (e.g., Fig. 23A), except in alteration halos, where vesicles are filled by celadonite, iddingsite, or celadonite followed by iddingsite (Fig. 23B-D). In the transitional zone inside of alteration halos, vesicles may be filled by celadonite, then iddingsite, followed by fibrous saponite and granular cryptocrystalline saponite with or without pyrite.

The pillow basalts from Hole 1025B contain vesicles with saponite linings, some white tabular crystals (zeolites?), and granular pyrite clusters (Fig. 22B, C). Associated secondary pyrite replaces glass nearby (Fig. 22D). In the rare alteration halos, vesicles are completely filled. The massive basalts from Hole $1025 \mathrm{C}$ contain vesicles and vugs that are usually lined or completely filled by saponite, some having early linings of pyrite (Fig. 13), and many of them also are partially filled by granular clusters of drusy pyrite. Uncommonly, vesicles contain a rhombic crystal of carbonate (calcite?) or acicular prisms of aragonite(?) (Fig. 24A, B), or fine euhedral crystals of zeolite (Fig. 24C), all of which are coated by a thin layer of fibrous saponite. Finally, an open fibrous matlike morphology is formed by clay in some vesicles from this hole (Fig. 24D).

\section{Veins}

Several vein types were noted, and individual occurrences are recorded in the vein log (Appendix D on CD-ROM, back pocket). The $0.05 \mathrm{~m}$ of hard rock core recovered at Site 1023 yielded four fractures/veins coated with pale blue clay and disseminated pyrite. The $0.15 \mathrm{~m}$ of hard rock recovered at Site 1024 contains no veins, similar to the $0.15 \mathrm{~m}$ of rock pieces recovered in Hole 1025B. Hole 1025C, 
A

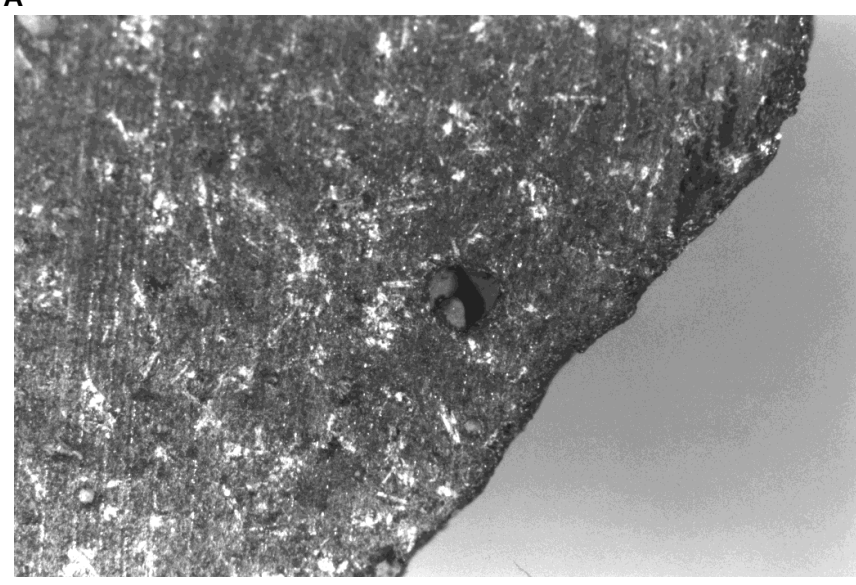

C

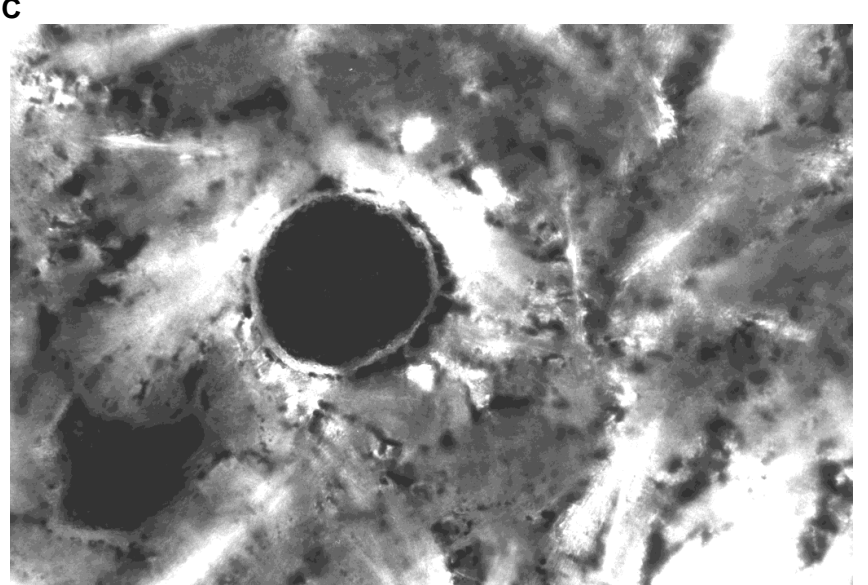

B

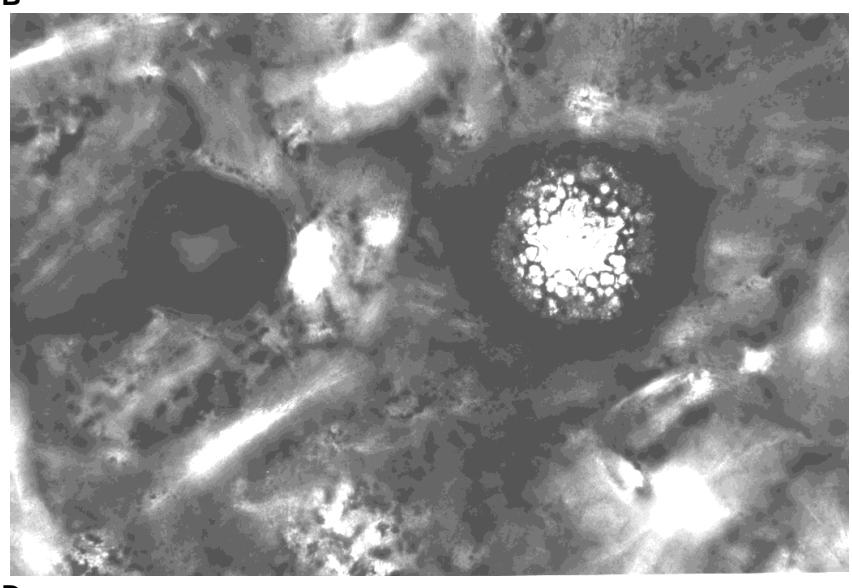

D

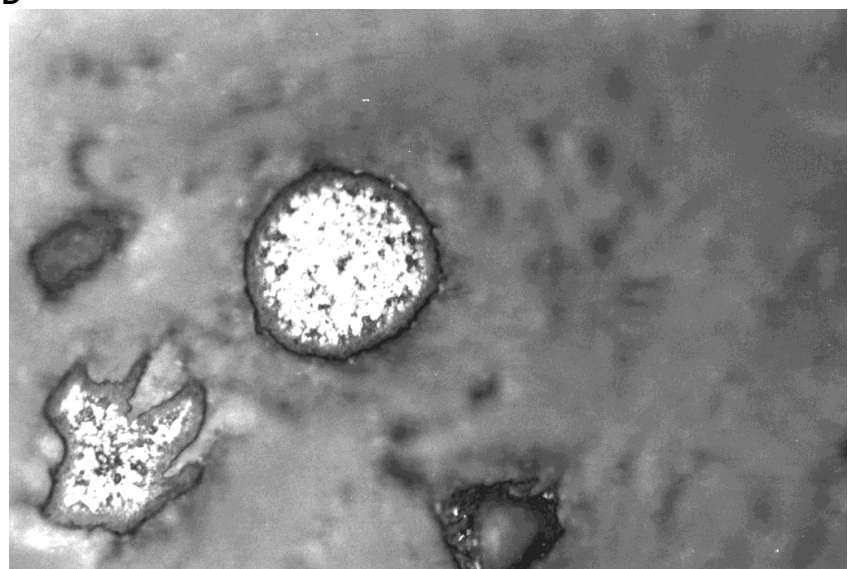

Figure 23. Photomicrographs illustrating several types of vesicle filling. A. Binocular microscope photograph of a sawed surface revealing a vesicle lined by pale blue saponite (Sample 168-1025B-11X-CC [Piece 4, 36-38 cm)]. Vesicle is $0.4 \mathrm{~mm}$ in diameter. B. Plane-polarized-light photomicrograph of two vesicles lined by iddingsite within an alteration halo (Sample 168-1024B-18X-CC [Piece 3, 9-27 cm]). Note the globular structure visible in the central iddingsite. The larger vesicle is $0.06 \mathrm{~mm}$ in diameter. C. Plane-polarized-light photomicrograph of a vesicle within the alteration halo lined by a layer of green celadonite followed by iddingsite (Sample 168-1024B-18X-CC [Piece 3, 9-27 cm]). The vesicle is $0.08 \mathrm{~mm}$ in diameter. D. Reflected-light photomicrograph of the same vesicle as in C. Note the high reflectivity of the iddingsite, which is isotropic in cross-polarized reflected light.

however, yielded $15.2 \mathrm{~m}$ of basaltic rock at an average recovery rate of $36.9 \%$. Included in this core are 111 logged veins, or about 7.3 veins/m, amounting to a vein abundance substantially lower than that obtained from a previous basement hole where veins were carefully logged (i.e., Hole 896A at the Costa Rica Rift, which contained $30 \pm$ 20 veins $/ \mathrm{m}$ )

The veins from Hole $1025 \mathrm{C}$ are dominated by clay ( 90 of the 111 veins), clay + talc (10 veins), or clay + carbonate ( 6 veins). There is one talc (alone) vein, one clay + pyrite vein, and three clay + quartz veins. Ninety-five veins were oriented relative to the core axis, and dips vary between $0^{\circ}$ and $90^{\circ}$, with weak modes around $45^{\circ}$ and $70^{\circ}$ (Fig. 25).

Clay veins are widespread at the Hydrothermal Transition sites. They may be simple dark green veins, which probably contain saponite alone, or more complex veins containing light green clay or yellow-green clay (celadonite and/or iddingsite) within alteration halos. Widths vary from several tens of micrometers to a maximum of 1 $\mathrm{mm}$; however, most are $\leq 0.1 \mathrm{~mm}$.

Veins with clay and calcium carbonate are sparse. Widths are uniformly $\leq 0.1 \mathrm{~mm}$. Both calcite and aragonite are recognized (Table 11).

One talc vein is present as a $0.1-\mathrm{mm}$-thick patch of fine spherulitic aggregates on the surface of Piece 5 in Section 168-1025C-5R-1 (Fig.
26). XRD results confirm the identity of talc. Ten nearby veins are logged as clay + talc, and one of these [Sample 168-1025C-5R-1 (Piece 10,65-66 cm)] also contains small black prismatic crystals that are unidentified.

Three clay + quartz veins are present in Section 168-1025C-2R-2; one is about $2 \mathrm{~mm}$ wide, has a clay border, and contains open vugs (Fig. 27). A thin section of this vein shows a thin orange-stained clay selvage, followed by massive chalcedonic quartz grading to drusy quartz ( $\leq 0.3 \mathrm{~mm}$ across) and the open vugs. The quartz is clear and contains no fluid inclusions.

\section{Spatial Variations of Alteration Mineralogy and Style}

\section{Variations in Alteration Intensity}

Pillow basalts from Hole 1023A are nearly totally fresh, containing only traces of saponite and pyrite. Olivines are completely unaltered. Pillow basalts from Holes 1024B and 1024C are only weakly altered; point counts of four thin sections (Table 12) reveal between $0 \%$ and $3 \%$ secondary minerals (saponite, celadonite, iddingsite, and pyrite).

The Hole 1025B pillow basalts are similarly weakly altered; two thin sections (Table 12) contain $1.2 \%-2.0 \%$ secondary minerals. In contrast, the massive basalts from Hole $1025 \mathrm{C}$ are considerably more 
A

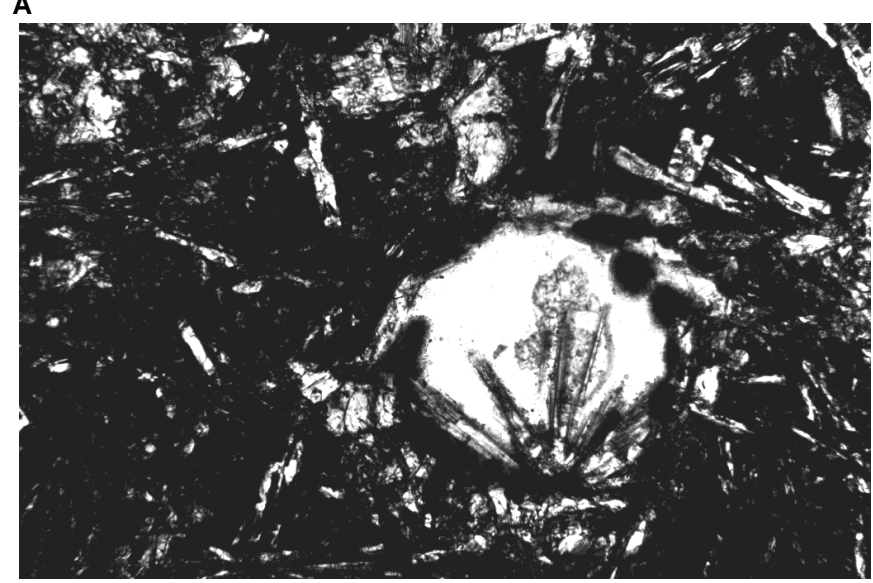

C

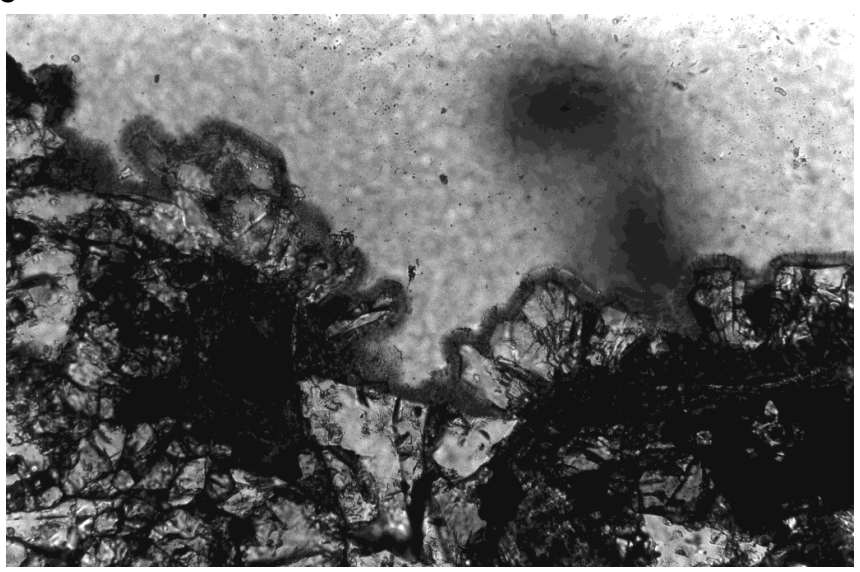

B

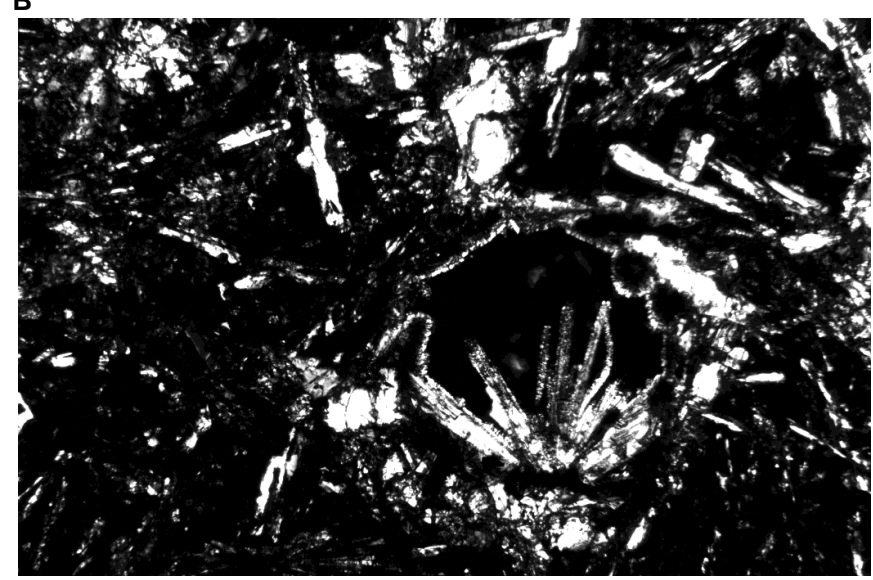

D

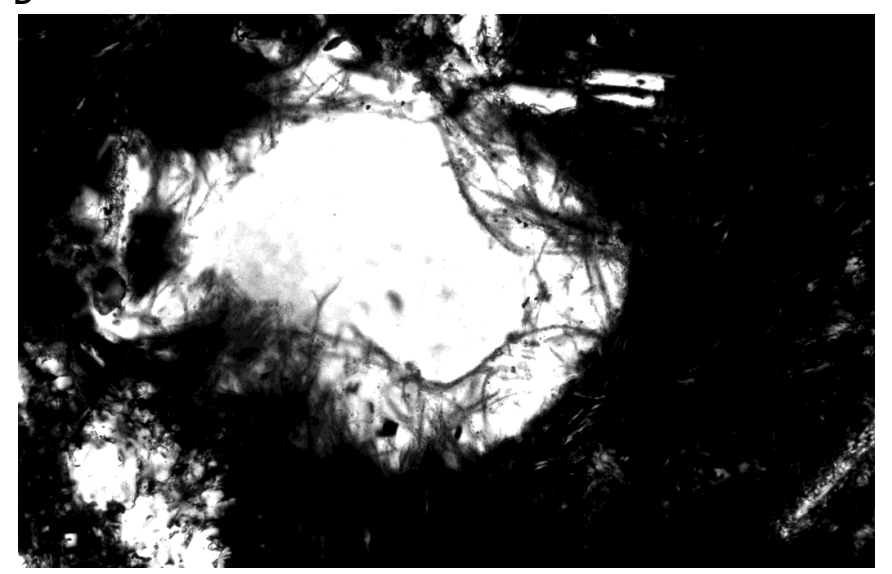

Figure 24. Photomicrographs of varieties of vesicle fillings. A. Open vesicle with a radial acicular arrangement of carbonate (aragonite?) crystals that are coated by fibrous saponite (plane-polarized light; Sample 168-1025C-2R-4 [Piece 12, 54-58 cm]). Vesicle diameter $=0.4 \mathrm{~mm}$. B. The same vesicle as in A in crosspolarized light. C. A vesicle wall lined (partially) by blocky euhedral zeolite(?) crystals that are coated by fibrous saponite (plane-polarized light; Sample 1681025C-1R-2 [Piece 3, 16-20 cm]). Field of view $=0.7 \mathrm{~mm}$. D. A vesicle lined with fibrous matted saponite (cross-polarized light; Sample 168-1025C-3R-1 $[$ Piece 7, 30-34 cm]. Vesicle diameter $=0.5 \mathrm{~mm}$.

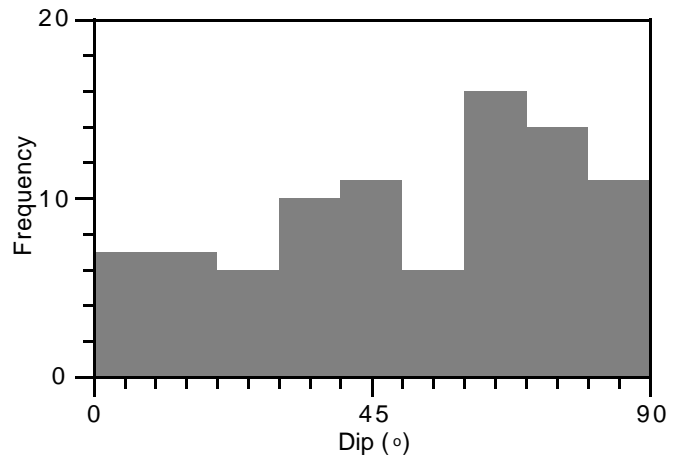

Figure 25. Histogram illustrating the variation in 111 vein dips (assuming a vertical core axis) measured on cores from Hole 1025C. Note the weak modes around $45^{\circ}$ and $70^{\circ}$.

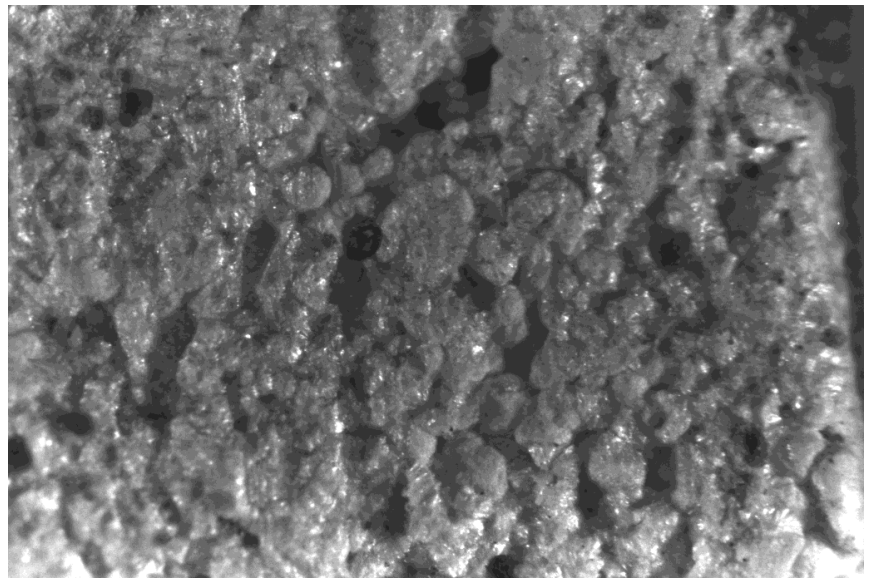

Figure 26. Binocular microscope photograph of the surficial talc vein in Sample 168-1025C-5R-1 (Piece 6). Note the pearly luster and the botryoidal and globular stellar habit. Field of view $=5.6 \mathrm{~mm}$. 
altered, containing between $1.4 \%$ and $24.5 \%$ secondary phases (based upon point counts of 13 thin sections).

Two controls on variations of alteration intensity may be postulated. One is temperature. The weakly altered rocks from Site 1023 are presently at $15.5^{\circ} \mathrm{C}$, whereas the slightly more altered rocks from Site 1024 are at $22.4^{\circ} \mathrm{C}$, and the more altered rocks from Site 1025 have an upper basement temperature of $38.2^{\circ} \mathrm{C}$. Elevated temperatures are expected to promote more rapid reaction rates.

Intrinsic permeability, which is dependent on grain parameters, may also control alteration intensity. Massive basalts are more altered than pillow basalts at Site 1025, perhaps reflecting a greater ease of access of hydrothermal fluid locally to the groundmass in these coarser grained rocks.

\section{Oxidative Alteration and Non-oxidative Alteration}

Low-temperature seafloor basalt alteration is often described in terms of two contrasting styles: oxidative and non-oxidative (Andrews, 1977; Laverne et al., 1996; Teagle et al., 1996). Iddingsite and celadonite, combined with the absence of sulfides, define the oxidative style, whereas saponite and sulfide minerals define the nonoxidative style. Most workers interpret the oxidative style of alteration to represent the effects of low-temperature basalt alteration by massive volumes of relatively unaltered seawater that has access to the basalts while they are exposed at the seafloor. Some workers suggest that an additional hydrothermal source of potassium and iron is necessary to form celadonite and iddingsite (e.g., Teagle et al., 1996). The non-oxidative alteration style is attributed to modified hydrothermal seawater that has lost much of its oxidizing potential.

At the Hydrothermal Transition sites, Hole 1023A is characterized by non-oxidative alteration. Samples from Site 1024 contain good examples of oxidative alteration in the form of celadonite- and iddingsite-bearing halos, combined with non-oxidative alteration in

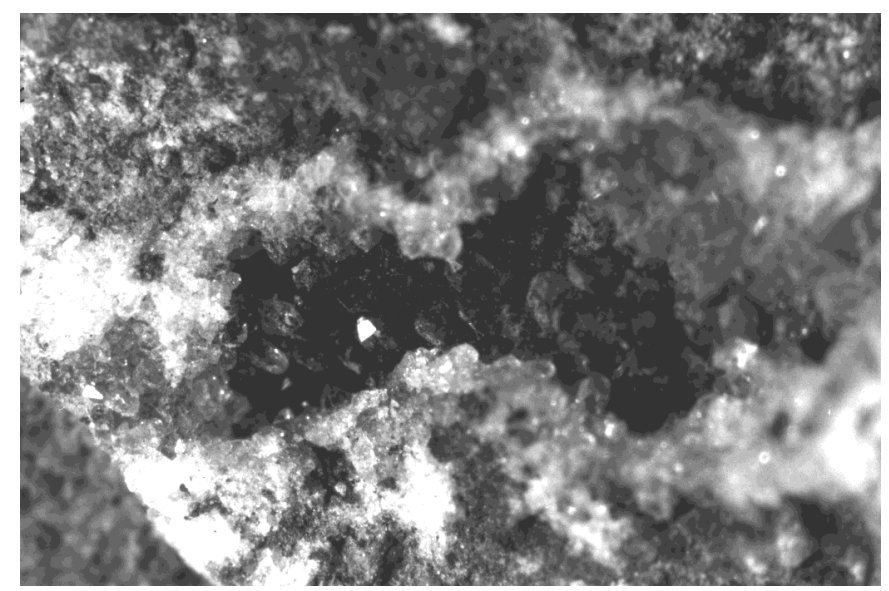

Figure 27. Binocular microscope photograph of the surficial vuggy quartz vein in Sample 168-1025C-2R-2 (Piece 10). Field of view $=7 \mathrm{~mm}$. the gray rock cores inside of halos. Site 1025 is mostly characterized by non-oxidative alteration, although traces of iddingsite (but no celadonite) occur.

A simple interpretation of the Hydrothermal Transition sites is that present-day basement water is the non-oxidative type because virtually all of the recovered cores contain rocks coated with thin layers or patches of saponite \pm pyrite. In some instances, pyrite was thought to have lost some of its brilliance and to have become tarnished in the ship's core lab with exposure to air. The presence of oxidative alteration halos, however, shows that some of the rocks (from Sites 1024 and 1025) were previously altered in an open seafloor setting. For some reason, this is not the case for the Site 1023 pillow basalts. One possibility is that Site 1023 , when it was young and before it was covered by sediment, was in a locally isolated hydrologic environment.

\section{Summary}

Basalts from the Hydrothermal Transition Transect illustrate progressive changes in alteration intensity related to increasing basement temperature from Site 1023 to Site 1024 to Site 1025 and to variations in lithology. Higher basement temperatures and coarser grain sizes combine to promote larger degrees of hydrothermal alteration, from a fraction of 1 percent in aphanitic pillow basalts at $15.5^{\circ} \mathrm{C}$ to $25 \%$ alteration in fine-grained massive basalts in basement that is $38.2^{\circ} \mathrm{C}$ at the basement/sediment interface. No alteration effects were observed that must have occurred at temperatures much higher that those prevailing today.

\section{AGE PROFILES}

\section{Calcareous Nannofossils}

Nannofossils are common to abundant in hemipelagic mud layers in Holes 1023A, 1024B, and 1025B but very rare or absent in turbidite beds. Nannofossils are generally well preserved throughout sediments of these holes, with slight dissolution but without overgrowth. Nannofossil age assignments are based on samples from the hemipelagic layers.

A late Quaternary nannofossil assemblage was found in sediments of these holes (Table 13). The base of the acme of Emiliania huxleyi was determined based on numeric counts that revealed the transition from the dominance of Gephyrocapsa muellerae to the dominance of E. huxleyi. The base of E. huxleyi needs to be reexamined by means of scanning electron microscope in a post-cruise study; with an optical microscope, small varieties of $E$. huxleyi are undistinguishable from same-sized Gephyrocapsa species. Another problem resides with the determination of the top of Gephyrocapsa caribbeanica. Around the extinction level of G. caribbeanica, this species is sparse and sporadic in samples from all these holes. The infrequent presence of this species can be caused either by reworking or by a frequent and strong dilution of turbidite materials; thus it is difficult to determine the last occurrence of this species. Otherwise, the last common occurrence of this species in sediment from these

Table 13. Stratigraphic list of calcareous nannofossil events and paleomagnetic reversals for Hydrothermal Transition Holes 1023A, 1024B, and 1025B.

\begin{tabular}{|c|c|c|c|c|c|c|c|}
\hline \multirow[b]{2}{*}{$\begin{array}{l}\text { Nannofossil and } \\
\text { paleomagnetic event }\end{array}$} & \multicolumn{2}{|c|}{ Hole 1023A } & \multicolumn{2}{|c|}{ Hole 1024B } & \multicolumn{2}{|c|}{ Hole $1025 B$} & \multirow[b]{2}{*}{$\begin{array}{l}\text { Age } \\
\text { (Ma) }\end{array}$} \\
\hline & $\begin{array}{l}\text { Core, section, } \\
\text { interval }(\mathrm{cm})\end{array}$ & $\begin{array}{l}\text { Depth } \\
\text { (mbsf) }\end{array}$ & $\begin{array}{l}\text { Core, section, } \\
\text { interval }(\mathrm{cm})\end{array}$ & $\begin{array}{l}\text { Depth } \\
\text { (mbsf) }\end{array}$ & $\begin{array}{l}\text { Core, section, } \\
\text { interval }(\mathrm{cm})\end{array}$ & $\begin{array}{l}\text { Depth } \\
\text { (mbsf) }\end{array}$ & \\
\hline B acme $E$. huxleyi & $5 \mathrm{H}-4,55$ & 42.85 & $4 \mathrm{H}-3,80$ & 30.40 & $4 \mathrm{H}-5,35$ & 30.50 & 0.09 \\
\hline T G. caribbeanica & $9 \mathrm{H}-1,25$ & 76.05 & $7 \mathrm{H}-7,88$ & 64.48 & $6 \mathrm{H}-1,78$ & 43.78 & 0.22 \\
\hline B E. huxleyi & $13 \mathrm{H}-2,100$ & 116.30 & $9 \mathrm{H}-7,55$ & 83.65 & $8 \mathrm{H}-5,90$ & 68.90 & 0.28 \\
\hline T P. lacunosa & 22X-CC, 41 & 192.87 & & & & & 0.46 \\
\hline Brunhes/Matuyama & & & $18 X-5$ & 166.20 & & & $\begin{array}{l}0.40 \\
0.78\end{array}$ \\
\hline
\end{tabular}

Note: $\mathrm{B}=$ bottom, and $\mathrm{T}=$ top 
three holes can be clearly correlated and is more reliable; thus it is used for this study. In Hole 1023A, the placement of the top of Pseudoemiliania lacunosa at $192.87 \mathrm{mbsf}$ is uncertain. Only a few specimens of this species were observed in the basal sediment overlying the basalt basement of Hole 1023A. The occurrence of $P$. lacunosa at this depth was taken as its last occurrence and used for Hole 1023A. P. lacunosa was not observed in sediments of Hole 1024B, although the Brunhes/Matuyama reversal was recognized at 166.2 mbsf in this hole. A further examination of sediments from Leg 168 in a post-cruise study is needed to determine why this species is not present in this hole. Furthermore, in Hole 1025B, P. lacunosa is absent through the entire sediment section. As the Brunhes/Matuyama reversal was also not recognized in this hole, the absence of $P$. lacunosa here implies the basal sediment of this hole to be younger than $0.46 \mathrm{Ma}$

Age/depth plots of nannofossil and paleomagnetic datums for these three holes (Fig. 28) indicate a general decrease in sedimentation rates from the western Hole 1023A toward the eastern Hole 1025B. Furthermore, as the ages of the basal sediments of all three holes are younger than their basements, sedimentation did not begin for several thousands of years after basement formation in this area.

\section{Magnetostratigraphy}

Paleomagnetic measurements were made on sediment cores recovered from Holes 1023A, 1024B, and 1025B to determine the magnetostratigraphy of the three sections drilled. These data were then combined with the micropaleontological data to produce a sedimentation rate/age profile for the sections.

The natural remanent magnetization (NRM) was measured for all the APC cores. The NRM results show very steep positive inclinations $\left(82^{\circ} \pm 5^{\circ}\right)$ throughout the cores (Fig. 29), which is interpreted to be a ubiquitous drilling-induced overprint. Stepwise AF demagnetization at NRM, 0, 5, 10, 15, 20, and $25 \mathrm{mT}$ of Cores 168-1023A$1 \mathrm{H}$ and $2 \mathrm{H}$ show the overprint to be generally removed by $15-20 \mathrm{mT}$ (Fig. 30). To remove the drilling overprint completely, the remaining cores were measured after $\mathrm{AF}$ demagnetization at $25 \mathrm{mT}$. In the absence of any core orientation and, hence, declination control, the inclination data were used as the primary indicator of magnetic polarity, although the declination data were used to delineate between true magnetic polarity changes and drilling-associated disturbances of the core that result in apparent changes in polarity.

$\mathrm{XCB}$ cores were only measured and demagnetized if there was $<50 \%$ drilling disturbance. Cores from the deeper sections of the holes (Cores 168-1023-16X, 1024-15X, and 1025-10X to the base of the holes) are strongly biscuited. Biscuited sediment pieces are free to rotate relative to one another in the core barrel, resulting in a loss of declination control within cores. There may also be a small amount of compaction of the sediments that may affect the inclinations by a small amount $\left(1^{\circ}-5^{\circ}\right)$.

Plots of inclinations after $25 \mathrm{mT}$ demagnetization (Fig. 31) show that the cores have almost exclusive positive magnetic polarities throughout. The average inclination after $25 \mathrm{mT}$ demagnetization is $70.7^{\circ} \pm 3^{\circ}$, which is similar to the predicted positive inclination for the area of $65^{\circ}-68^{\circ}$. The small reversed polarity section from 11 to 16 mbsf in both Holes 1023A and 1025B may represent a short event within the Brunhes; however, an equivalent event is not recognizable in cores from Hole 1024B. Other intervals of scatter in the data away from steep positive inclinations occur within sandy units that are highly disturbed by drilling or within sections containing numerous small turbidites; the data from these intervals are considered to be unrepresentative of in situ conditions.

At the base of Hole 1024B, there is a reversal of the magnetic polarity of the cores. Demagnetization after $25 \mathrm{mT}$ data for Core 1681024B-18X shows a magnetic polarity reversal within the bottom two sections (Fig. 32). Core 168-1024B-18X is the deepest sediment core from Hole 1024B and comprises biscuited pelagic sediment (see "Lithostratigraphy" section, this chapter, and visual core descriptions in Section 3, this volume). The average inclination after $25 \mathrm{mT}$ demagnetization of the interval $160.0-165.8 \mathrm{mbsf}$ is $+69^{\circ} \pm 3^{\circ}$; this is representative of Sections 168-1024B-1H-1 through 18X-4. The average inclination after $25 \mathrm{mT}$ demagnetization for the interval 165.8$167 \mathrm{mbsf}$ is $-67^{\circ} \pm 8^{\circ}$, similar to the predicted reversed polarity field inclination in the area $\left(-65^{\circ}\right.$ to $\left.-68^{\circ}\right)$. Demagnetization results from the two samples show that there is a polarity difference in the stable remanence components over this apparent reversal (Fig. 33; Table 14). Both samples have very steep positive magnetization components that are easily removed by $10-12 \mathrm{mT}$ and are interpreted to be drilling-induced magnetizations. Sample 168-1024B-18X-4, 115$117 \mathrm{~cm}$, has a steep positive inclination interpreted to be a Brunhes polarity magnetization modified by drilling-induced magnetization. In contrast, Sample 168-1024B-18X-5, 24-26 cm, has a stable remanence component of inclination of $-33.3^{\circ}$, interpreted to be a Matuyama reversed polarity remanence.

In conclusion, the sediment sequences recovered at Sites 1023 through 1025 are entirely of Brunhes magnetic polarity age, except for the basal $115 \mathrm{~cm}$ of Hole 1024B, interpreted to be of latest Matuyama age. A short interval of shallow inclinations (165.7-166.1
Figure 28. Age and depth correlation of nannofossil and paleomagnetic datums, as well as sedimentation rates in centimeters per thousand years (in parentheses), for Hydrothermal Transition Holes 1023A, 1024B, and 1025B. Basement ages of these three holes are also given here to show that sedimentation did not begin for several thousands of years after basement formation in this area.
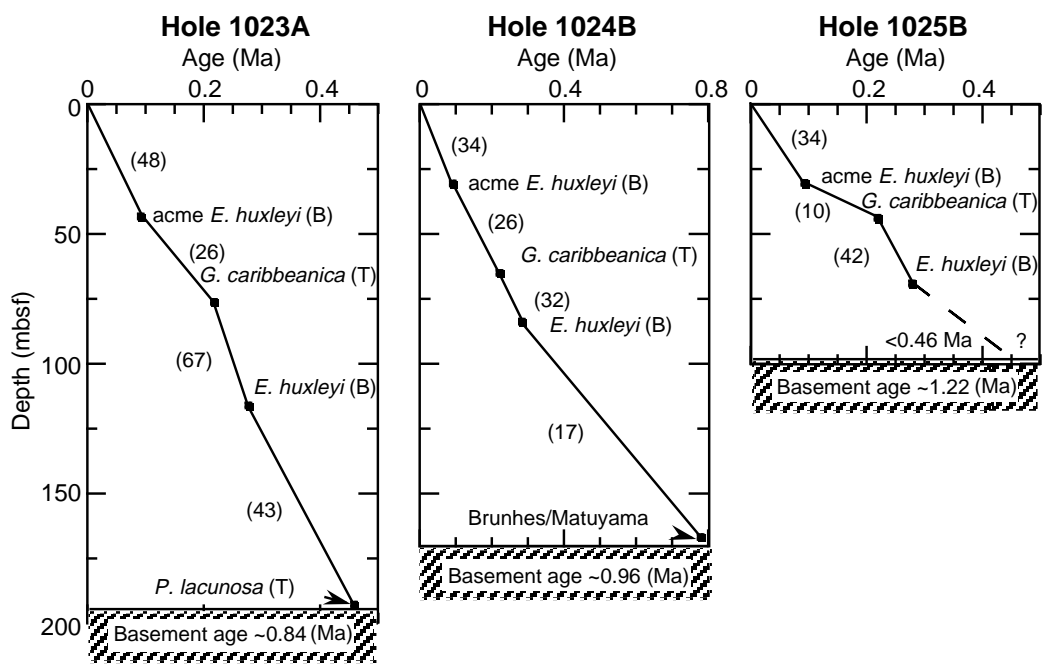


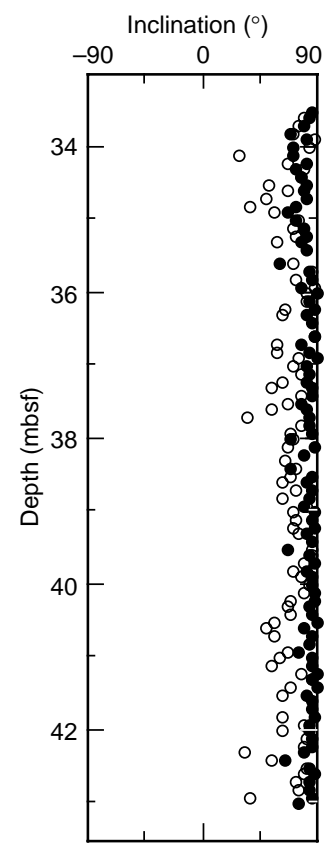

Figure 29. Natural remanent magnetization (solid circles) and remanence after $25 \mathrm{mT}$ demagnetization (open circles) for Core 168-1025B-5H, showing steep positive inclinations $\left(\sim 80^{\circ}\right)$ of the NRM interpreted to be a drillinginduced remanence. Drilling-induced remanence is removed at $15-20 \mathrm{mT}$ to reveal predominantly positive inclinations $\left(60^{\circ}-80^{\circ}\right)$ interpreted as Brunhes positive inclination remanent magnetization.
A

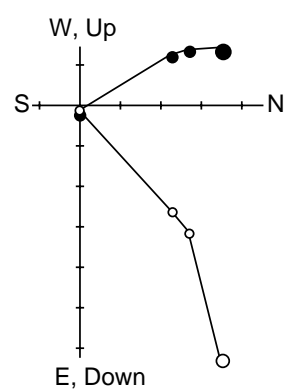

1023A-1H-3, $10 \mathrm{~cm}$
B

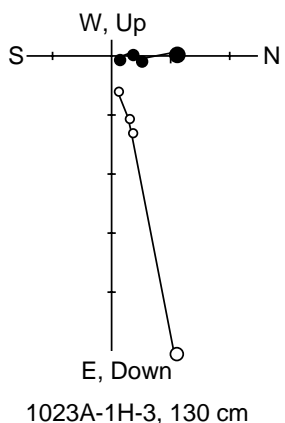

Figure 30. Vector end-point diagrams taken from continuous core stepwise demagnetizations. Drilling-induced magnetization is ubiquitous in the cores and developed to varying amounts. A. The stable remanence of partially overprinted sections can be isolated by demagnetization at fields $\leq 20 \mathrm{mT}$. B. Identification of the primary remanent magnetization is not possible in regions of complete overprinting by the drilling. Open circles $=$ the projection of the remanence into the vertical plane. Solid symbols $=$ the projection of the remanence into the horizontal plane.

mbsf) in Hole 1024B is interpreted to represent the Brunhes/ Matuyama polarity transition.

\section{FLUID GEOCHEMISTRY}

\section{Introduction}

Pore waters were extracted and analyzed from 83 squeezed whole-round samples from Sites 1023, 1024, and 1025 (see "Methods" chapter, this volume) (Table 15). In general, chemical profiles comprise three distinct vertical zones, including an upper and lower

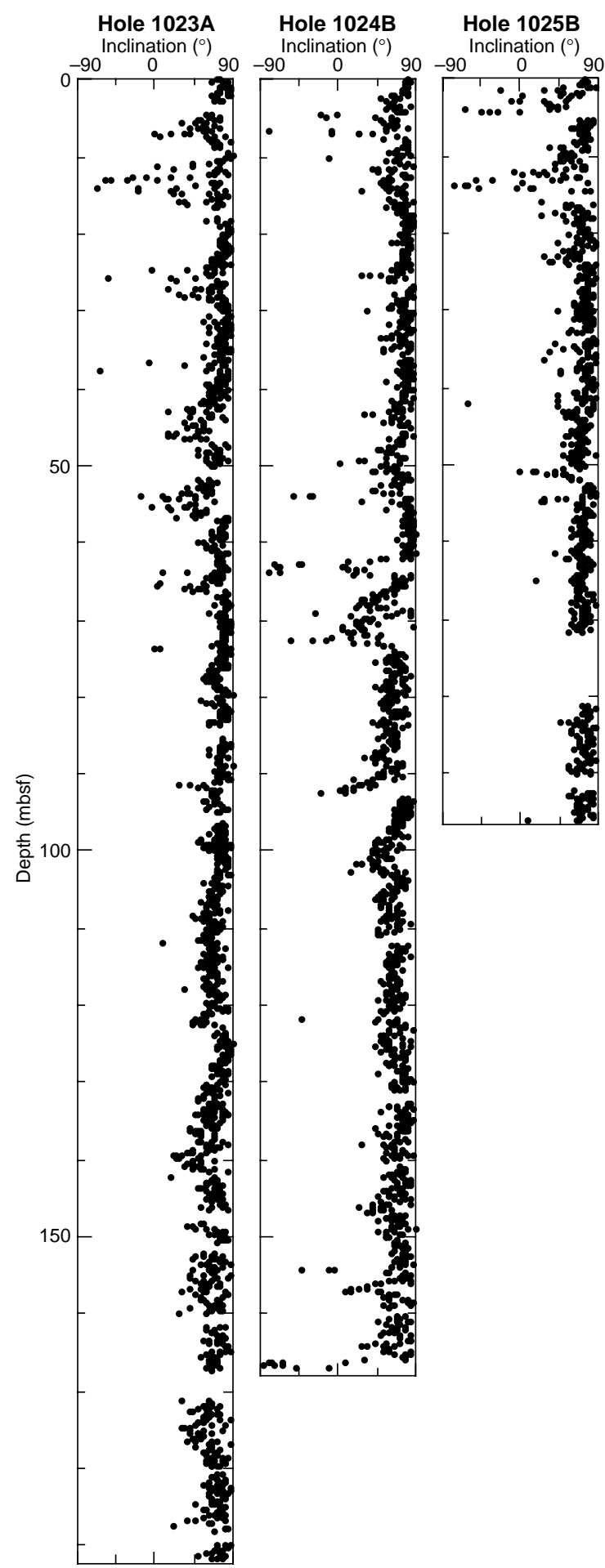

Figure 31. Remanent magnetization inclination data after $25 \mathrm{mT}$ demagnetization for the Hydrothermal Transition sites. A small reversed polarity section exists at $\sim 10-15$ mbsf at Sites 1023 and 1025, possibly representing an event in the late Brunhes. The Brunhes/Matuyama transition is identifiable in sediment from the base of Hole 1024B (165 mbsf).

zone, both of which reflect the balance between reaction in the sediment section and diffusional exchange with either bottom seawater or fluid in basement. The intermediate depth zone is essentially closed (relative to the other two zones) from diffusional communication with bottom or basement waters. Not all of these zones are represented in each site, but this classification provides a useful framework in 
which to discuss the main processes that affect pore-water geochemistry. Based on the detailed concentration profiles for 12 chemical species from each of the three sites (Fig. 34), pore waters are influenced by three fundamental processes: reaction with sediments (e.g., diagenesis of organic matter and clays and the effects of reaction in turbidites), pore-water flow through basement and overlying sediments, and water/rock reactions in basement.

\section{Diagenesis of Organic Matter}

Profiles of sulfate, alkalinity, and ammonia (Fig. 34) reflect the in situ bacterial degradation of organic matter. It is known from work on short cores in this area (M. Mottl, unpubl. data) that dissolved oxygen and nitrate are completely exhausted as oxidants of organic matter within the upper $20 \mathrm{~cm}$ of the sediments. As a consequence, the main oxidant consumed during bacterial degradation of organic matter is sulfate, as described by the following simplified stoichiometric reaction:

$$
2 \mathrm{CH}_{2} \mathrm{O}+\mathrm{SO}_{4}{ }^{2-}=\mathrm{H}_{2} \mathrm{~S}+2 \mathrm{HCO}_{3}^{-}
$$

This is seen in the initial decrease in sulfate with depth. In this upper zone, sulfate reduction is initiated close below the sediment/ seawater interface and proceeds systematically with depth/time. We infer that sulfate reduction is occurring within the upper $50 \mathrm{~m}$ at Site 1023, $100 \mathrm{~m}$ at Site 1024, and $25 \mathrm{~m}$ at Site 1025. Associated with sul-

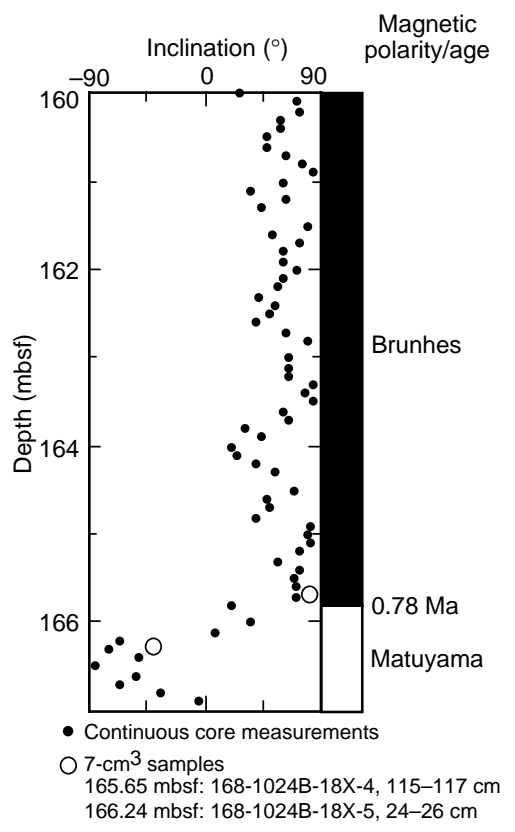

Figure 32. Inclination data after $25 \mathrm{mT}$ demagnetization for Core 168-1024B$18 \mathrm{X}$, showing the Brunhes/Matuyama transition at $165.8 \mathrm{mbsf}$. fate reduction, there is alkalinity production (as expected from the above equation) and remineralization of organic $\mathrm{N}$ and $\mathrm{P}$ as dissolved ammonia and phosphate (Fig. 34).

In the intermediate zone at Sites 1023 and 1024, dissolved sulfate largely has been exhausted. At such depths, oxidation of organic matter proceeds via fermentation processes rather than respiratory processes, and organic rather than inorganic compounds are used as electron acceptors. High methane concentrations in this depth zone at Sites 1023 and 1024 provide direct evidence for methanogenesis. Methane is absent at Site 1025 because sulfate is not exhausted (see "Organic Geochemistry" section, this chapter). At Site 1025 the intermediate zone is defined by a minimum in the sulfate profile (rather than a broad depth zone) because of the greater influence of the basement reservoir in this thinner sediment section.

\section{Inorganic Diagenesis and Mineral Reactivity}

Of the inorganic geochemical processes within the sediments that can be inferred from the pore-water profiles, three involve the products of organic matter diagenesis. The first of these is ubiquitous during marine organic diagenesis in that the $\mathrm{H}_{2} \mathrm{~S}$ produced by sulfate reduction must have reacted with $\mathrm{Fe}^{2+}$ to be removed as pyrite, commonly found in the form of framboids (see "Lithostratigraphy" section, this chapter).

The second process is that of calcium carbonate precipitation. The decrease in pore-water sulfate with depth is, as expected, mirrored by an increase in alkalinity (Fig. 34). However, the increase in alkalinity should be twice the observed decrease in sulfate, whereas it is much less than expected from this stoichiometry (Fig. 35). Thus, calcium carbonate must be precipitating in this depth interval. This is consistent with preliminary saturation-state calculations that show that the pore waters are supersaturated with calcite within the intermediate depth zone at Sites 1023, 1024, and 1025 but are undersaturated above and below this zone, where the pore waters are in diffusive

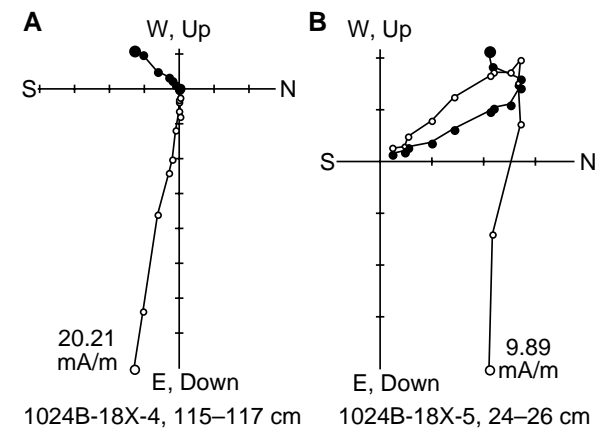

Figure 33. Vector end-point diagrams for two samples taken from the Brunhes/Matuyama transition recovered at Site 1024. (A) shows a small drilling-induced remanence almost indistinguishable from its stable positive remanence, whereas $(\mathbf{B})$ shows a steep positive drilling-induced remanence that is removed by $10 \mathrm{mT}$ and clearly distinguishable from the stable reversed polarity remanence of the sample. Symbols are the same as in Figure 30.

Table 14. Susceptibility, natural remanent magnetization, and characteristic magnetization declination, inclination, and alternating-field treatment steps over which the cleaned direction was defined for two samples taken at the Brunhes/Matuyama transition at Site 1024.

\begin{tabular}{|c|c|c|c|c|c|c|c|c|}
\hline \multirow[b]{2}{*}{$\begin{array}{l}\text { Core, section, } \\
\text { interval }(\mathrm{cm})\end{array}$} & \multirow[b]{2}{*}{$\begin{array}{l}\text { Depth } \\
\text { (mbsf) }\end{array}$} & \multirow[b]{2}{*}{$\begin{array}{c}\mathrm{K} \\
\left(\times 10^{-5} \mathrm{SI}\right)\end{array}$} & \multirow[b]{2}{*}{$\begin{array}{c}\mathrm{NRM} \\
(\mathrm{mA} / \mathrm{m})\end{array}$} & \multicolumn{4}{|c|}{ Cleaned directions } & \multirow[b]{2}{*}{ Magnetic polarity } \\
\hline & & & & $\begin{array}{c}\text { Declination } \\
\left({ }^{\circ}\right)\end{array}$ & $\begin{array}{c}\text { Inclination } \\
\left({ }^{\circ}\right)\end{array}$ & $\begin{array}{c}\text { Lower } \\
(\mathrm{mT})\end{array}$ & $\begin{array}{c}\text { Upper } \\
(\mathrm{mT})\end{array}$ & \\
\hline \multicolumn{9}{|l|}{ 1024B- } \\
\hline $18 X-4,115-117$ & 165.65 & 23 & 20.21 & 224.0 & 82.0 & 0 & 03 & Drilling overprint \\
\hline $18 X-5,24-26$ & 166.24 & 19 & 9.89 & $\begin{array}{l}221.8 \\
226.0 \\
333.6\end{array}$ & $\begin{array}{r}77.6 \\
80.4 \\
-33.3\end{array}$ & $\begin{array}{l}2.5 \\
0 \\
12\end{array}$ & $\begin{array}{l}25 \\
12 \\
50\end{array}$ & $\begin{array}{l}\text { Brunhes } \\
\text { Drilling overprint } \\
\text { Matuyama }\end{array}$ \\
\hline
\end{tabular}


Table 15. Composition of pore waters from sediments from Sites 1023, 1024, and 1025.

\begin{tabular}{|c|c|c|c|c|c|c|c|c|c|c|c|c|c|c|c|c|c|}
\hline $\begin{array}{l}\text { Core, section, } \\
\text { interval }(\mathrm{cm})\end{array}$ & $\begin{array}{c}\text { Volume } \\
(\mathrm{mL})\end{array}$ & $\begin{array}{c}\text { Squeeze } \mathrm{T} \\
\left({ }^{\circ} \mathrm{C}\right)\end{array}$ & $\begin{array}{c}\text { In situ } \mathrm{T} \\
\left({ }^{\circ} \mathrm{C}\right)\end{array}$ & $\begin{array}{l}\text { Depth } \\
\text { (mbsf) }\end{array}$ & $\begin{array}{l}\text { Salinity } \\
\text { (R.I.,\%) }\end{array}$ & $\mathrm{pH}$ & $\begin{array}{r}\text { Alkalinity } \\
(\mathrm{meq} / \mathrm{kg})\end{array}$ & $\begin{array}{l}\text { Chlorinity } \\
(\mathrm{mmol} / \mathrm{kg})\end{array}$ & $\begin{array}{c}\text { Sulfate } \\
(\mathrm{mmol} / \mathrm{kg})\end{array}$ & $\begin{array}{c}\mathrm{Na} \\
(\mathrm{mmol} / \mathrm{kg})\end{array}$ & $\underset{(\mathrm{mmol} / \mathrm{kg})}{\mathrm{K}}$ & $\begin{array}{c}\mathrm{Mg} \\
(\mathrm{mmol} / \mathrm{kg})\end{array}$ & $\begin{array}{c}\mathrm{Ca} \\
(\mathrm{mmol} / \mathrm{kg})\end{array}$ & $\begin{array}{c}\mathrm{Si} \\
(\mu \mathrm{mol} / \mathrm{kg})\end{array}$ & $\begin{array}{c}\mathrm{NH}_{3} \\
(\mu \mathrm{mol} / \mathrm{kg})\end{array}$ & $\begin{array}{c}\mathrm{PO}_{4} \\
(\mu \mathrm{mol} / \mathrm{kg})\end{array}$ & $\mathrm{Na} / \mathrm{Cl}$ \\
\hline \multicolumn{18}{|l|}{ 168-1023A- } \\
\hline $1 \mathrm{H}-1,140-150$ & 50 & 6.6 & 1.9 & 1.45 & 35.0 & 7.90 & 4.60 & 545.3 & 25.72 & 470.1 & 11.13 & 48.67 & 10.26 & 506 & 209 & 14.2 & 0.8620 \\
\hline $1 \mathrm{H}-2,140-150$ & 60 & 6.8 & 2.0 & 2.95 & 35.0 & 7.83 & 6.18 & 545.2 & 24.66 & 469.8 & 11.33 & 48.49 & 9.91 & 501 & 285 & 15.0 & 0.8617 \\
\hline $1 \mathrm{H}-3,140-150$ & 60 & $\begin{array}{l}0.0 \\
9.0\end{array}$ & 2.1 & 4.45 & 34.5 & 7.80 & $\begin{array}{l}.100 \\
7.81\end{array}$ & 542.7 & 22.69 & 466.0 & 11.28 & 47.17 & 9.88 & 499 & 463 & 22.2 & 0.8587 \\
\hline $1 \mathrm{H}-4,140-150$ & 60 & $\begin{array}{r}9.0 \\
11.0\end{array}$ & 2.2 & $\begin{array}{l}4.45 \\
5.95\end{array}$ & 34.5 & $\begin{array}{l}7.00 \\
7.82\end{array}$ & 8.91 & 543.3 & 22.14 & 468.9 & $\begin{array}{l}11.60 \\
11.60\end{array}$ & 46.40 & $\begin{array}{l}9.00 \\
9.60\end{array}$ & 467 & $\begin{array}{l}403 \\
666\end{array}$ & 11.9 & $\begin{array}{l}.0301 \\
0.8631\end{array}$ \\
\hline $1 \mathrm{H}-5,140-150$ & 30 & 11.5 & 2.3 & 7.45 & 34.5 & 7.90 & 16.37 & 545.1 & 19.60 & 473.2 & 11.10 & 47.63 & 9.82 & 395 & 1245 & 12.6 & 0.8681 \\
\hline $2 \mathrm{H}-1,140-150$ & 50 & 6.0 & 2.6 & 10.75 & 34.5 & 8.08 & 11.32 & 549.8 & 14.22 & 467.0 & $\begin{array}{l}10.10 \\
10.79\end{array}$ & 46.54 & 8.55 & 490 & 1270 & 61.3 & 0.8493 \\
\hline $2 \mathrm{H}-5,140-150$ & 55 & $\begin{array}{l}0.0 \\
6.1\end{array}$ & $\begin{array}{l}. .0 \\
3.0\end{array}$ & 16.75 & 34.5 & $\begin{array}{l}0.00 \\
7.98\end{array}$ & 20.56 & 551.7 & 9.30 & $\begin{array}{l}401.9 \\
471.9\end{array}$ & 10.21 & 47.12 & 7.01 & 559 & 1531 & 78.4 & $\begin{array}{l}0.0495 \\
0.8554\end{array}$ \\
\hline $3 \mathrm{H}-5,140-150$ & 55 & 7.0 & 3.7 & 26.25 & 34.0 & 7.94 & 26.47 & 551.5 & 5.76 & 474.8 & 10.62 & 45.68 & 6.03 & 540 & 1709 & 72.6 & 0.8609 \\
\hline $4 \mathrm{H}-5,140-150$ & 55 & 9.1 & 4.3 & 35.75 & 33.5 & 7.73 & 28.45 & 552.4 & 2.02 & 475.4 & 10.37 & 44.01 & 5.28 & 731 & 2115 & 72.6 & 0.8605 \\
\hline $5 \mathrm{H}-5,140-150$ & 55 & 8.3 & 5.0 & 45.25 & 33.5 & 8.03 & 28.59 & 553.2 & 0.91 & 475.9 & 9.66 & 45.21 & 4.61 & 602 & 2115 & 62.6 & 0.8603 \\
\hline $6 \mathrm{H}-5,140-150$ & 28 & - & 5.7 & 54.75 & 33.0 & 8.03 & 29.03 & 552.1 & 0.27 & 474.0 & 9.33 & 44.57 & 4.26 & 559 & 2077 & 38.9 & 0.8585 \\
\hline $7 \mathrm{H}-5,140-150$ & 55 & 8.5 & 6.4 & 64.25 & 33.0 & 7.83 & 27.58 & 550.7 & 0.00 & 471.9 & 8.92 & 44.23 & 4.45 & 592 & 2211 & 30.8 & 0.8569 \\
\hline $8 \mathrm{H}-5,140-150$ & 55 & - & 7.0 & 73.75 & 32.5 & 7.69 & 27.08 & 551.0 & 0.10 & 471.3 & 8.65 & 44.02 & 4.74 & 788 & 2331 & 52.9 & 0.8554 \\
\hline $9 \mathrm{H}-5,140-150$ & 55 & 7.2 & 7.7 & 82.85 & 32.5 & 7.77 & 26.93 & 553.2 & 0.54 & 474.3 & 8.85 & 44.00 & 5.14 & 638 & 2223 & 24.0 & 0.8574 \\
\hline $10 \mathrm{H}-5,140-150$ & 55 & 9.1 & 8.4 & 92.75 & 32.5 & 7.83 & 26.95 & 553.5 & 0.44 & 473.2 & $\begin{array}{l}0.05 \\
8.55\end{array}$ & 43.95 & 5.71 & 627 & 2388 & 40.7 & 0.8549 \\
\hline $11 \mathrm{H}-5,140-150$ & 55 & 9.1 & $\begin{array}{l}. .4 \\
9.1\end{array}$ & 102.25 & 32.5 & $\begin{array}{l}1.03 \\
7.78\end{array}$ & 25.78 & 552.7 & 0.16 & 473.4 & 8.06 & 43.23 & 5.68 & 784 & 2280 & 27.2 & $\begin{array}{l}0.0349 \\
0.8566\end{array}$ \\
\hline $12 \mathrm{H}-5,140-150$ & 55 & $\begin{array}{l}9.1 \\
9.1\end{array}$ & $\begin{array}{l}9.1 \\
9.7\end{array}$ & $\begin{array}{l}102.75 \\
111.75\end{array}$ & 33.0 & 7.70 & 24.36 & 554.0 & $\begin{array}{l}0.10 \\
1.14\end{array}$ & $\begin{array}{l}475.4 \\
475.6\end{array}$ & $\begin{array}{l}8.00 \\
8.39\end{array}$ & 42.47 & $\begin{array}{l}5.08 \\
5.84\end{array}$ & 712 & 2230 & 29.1 & $\begin{array}{l}0.8300 \\
0.8585\end{array}$ \\
\hline $13 \mathrm{H}-5,140-150$ & 50 & 9.6 & 10.4 & 121.25 & 33.0 & 7.98 & 22.40 & 551.0 & 0.38 & 471.8 & $\begin{array}{l}8.37 \\
8.67\end{array}$ & 42.45 & 5.25 & 514 & 2204 & 14.7 & 0.8563 \\
\hline $14 \mathrm{H}-4,140-150$ & 40 & $\begin{array}{r}9.0 \\
10.6\end{array}$ & $\begin{array}{l}11.0 \\
11.0\end{array}$ & 129.25 & 33.0 & 7.73 & 22.40 & 553.4 & 0.15 & 451.3 & $\begin{array}{l}0.01 \\
7.15\end{array}$ & 42.08 & 5.31 & $\begin{array}{r}314 \\
490\end{array}$ & 1842 & 12.1 & 0.8155 \\
\hline $15 \mathrm{X}-2,135-150$ & 55 & 8.7 & 11.2 & 132.93 & 33.0 & 7.90 & 19.21 & 548.8 & 1.38 & 468.5 & 7.69 & 41.94 & 5.61 & 473 & 1747 & 13.7 & $\begin{array}{l}0.81537 \\
0.8537\end{array}$ \\
\hline $16 \mathrm{X}-3,135-150$ & 55 & 7.5 & 11.5 & 137.13 & 33.0 & 7.75 & 19.39 & 548.1 & 1.32 & 468.2 & 7.95 & 41.04 & 6.27 & 508 & 1683 & 15.6 & 0.8542 \\
\hline $17 \mathrm{X}-3,135-150$ & 55 & - & 12.2 & 146.73 & 32.5 & 7.76 & 19.21 & 551.3 & 0.85 & 472.2 & 7.99 & 39.87 & 6.53 & 722 & 1645 & 24.0 & 0.8566 \\
\hline $18 \mathrm{X}-4,135-150$ & 55 & 8.2 & 13.0 & 157.83 & 33.0 & 7.70 & 14.42 & 549.1 & 4.62 & 471.0 & 8.34 & 39.96 & 6.74 & 497 & 1403 & 11.4 & 0.8578 \\
\hline $19 \mathrm{X}-2,135-150$ & 55 & 8.2 & 13.5 & 164.53 & 33.0 & 7.87 & 12.78 & 546.9 & 7.58 & 469.2 & 8.74 & 40.69 & 7.53 & 802 & 1305 & 5.9 & 0.8580 \\
\hline $20 \mathrm{X}-4,135-150$ & 55 & 7.7 & 14.4 & 177.13 & 34.0 & 7.75 & 9.32 & 550.3 & 13.36 & 473.6 & 8.90 & 42.34 & 9.21 & 520 & 846 & 5.7 & 0.8606 \\
\hline $21 \mathrm{X}-3,135-150$ & 42 & - & 15.0 & 185.23 & 34.0 & 7.85 & 6.49 & 546.7 & 19.74 & 470.9 & 9.96 & 45.25 & 10.63 & 737 & 520 & 4.1 & 0.8614 \\
\hline $21 \mathrm{X}-4,135-150$ & 55 & 二 & 15.1 & 186.73 & 34.0 & $\begin{array}{l}1.03 \\
7.78\end{array}$ & 4.82 & 545.6 & 20.81 & 471.1 & 10.42 & 45.42 & 10.47 & 870 & 476 & 4.5 & 0.8635 \\
\hline $21 \mathrm{X}-5,110-125$ & 55 & 二 & 15.1 & 187.98 & 34.0 & 7.73 & 3.91 & 541.5 & 21.45 & 467.3 & 10.29 & 45.77 & 10.19 & 901 & 429 & 2.9 & 0.8630 \\
\hline 21X-6, 75-85 & 55 & 二 & 15.2 & 189.10 & 34.0 & 7.67 & 3.53 & 542.3 & 22.87 & 468.3 & $\begin{array}{l}10.29 \\
10.53\end{array}$ & 46.00 & 10.56 & 863 & 377 & 2.0 & $\begin{array}{l}0.8030 \\
0.8635\end{array}$ \\
\hline $22 \mathrm{X}-1,88-103$ & 55 & 二 & 15.4 & 191.36 & 34.0 & 7.86 & 3.50 & 543.2 & 23.81 & 466.8 & 10.52 & 47.46 & 11.32 & 638 & 258 & 2.7 & 0.8593 \\
\hline $22 \mathrm{X}-2,47-62$ & 55 & - & 15.4 & 191.98 & 34.0 & 7.78 & 2.89 & 542.1 & 24.15 & 465.1 & 10.05 & 47.23 & 11.54 & 600 & 220 & 2.7 & 0.8580 \\
\hline Basement at: & & & 15.5 & 192.80 & & & & & & & & & & & & & \\
\hline \multicolumn{18}{|c|}{ Basement age $=0.860 \mathrm{Ma}$} \\
\hline \multicolumn{18}{|c|}{$168-1024 \mathrm{~A}-$} \\
\hline $1 \mathrm{H}-1,115-125$ & 55 & 8.9 & 2.0 & 1.20 & 34.5 & 7.75 & 3.84 & 543.1 & 26.22 & 466.4 & 11.97 & 50.72 & 9.80 & 544 & 0 & 14.8 & 0.8587 \\
\hline $1 \mathrm{H}-2,140-150$ & 55 & 9.2 & 2.2 & 2.80 & 34.5 & 7.77 & 5.44 & 544.1 & 25.83 & 471.6 & 11.80 & 48.97 & 9.96 & 474 & 154 & 12.9 & 0.8667 \\
\hline $1 \mathrm{H}-3,140-150$ & 55 & 6.8 & 2.3 & 4.30 & 34.5 & 7.48 & 7.01 & 546.0 & 24.05 & 472.7 & 11.30 & 48.66 & 9.88 & 496 & 216 & 15.2 & 0.8658 \\
\hline $1 \mathrm{H}-4,140-150$ & 20 & 6.5 & 2.5 & 5.80 & 34.5 & 8.06 & 9.41 & 546.9 & 21.99 & 471.3 & 11.61 & 48.95 & 9.75 & 363 & 328 & 12.5 & 0.8618 \\
\hline $1 \mathrm{H}-5,140-150$ & 55 & 7.3 & 2.7 & 7.30 & 34.5 & 7.80 & 10.70 & 549.9 & 20.22 & 474.8 & 11.44 & 47.81 & 9.60 & 512 & 750 & 50.9 & 0.8634 \\
\hline $1 \mathrm{H}-6,140-150$ & 55 & 6.4 & 2.9 & 8.80 & 34.0 & 7.80 & 12.31 & 549.8 & 18.67 & 474.5 & 11.25 & 47.52 & 9.35 & 481 & 935 & 48.1 & 0.8630 \\
\hline \multirow{2}{*}{\multicolumn{18}{|c|}{ 168-1024B- }} \\
\hline $1 \mathrm{H}-1,140-150$ & & & & & & & & & & & & & & & & & 0.8582 \\
\hline $1 \mathrm{H}-2,140-150$ & 55 & 7.1 & 2.2 & 2.95 & 35.0 & 7.78 & 5.49 & 542.4 & 25.88 & 469.8 & 11.06 & 49.38 & 10.00 & 462 & 181 & 17.9 & 0.8662 \\
\hline $1 \mathrm{H}-3,140-150$ & 50 & -1.1 & 2.4 & 4.45 & 35.0 & 7.64 & 7.24 & 545.2 & 23.46 & 470.4 & 11.16 & 48.97 & 9.96 & 474 & 448 & 11.9 & 0.8628 \\
\hline $1 \mathrm{H}-5,140-150$ & 55 & 7.0 & 2.7 & 7.33 & 35.0 & $\begin{array}{l}7.04 \\
7.90\end{array}$ & 11.56 & 545.8 & 21.26 & 473.9 & 11.37 & $\begin{array}{l}4.91 \\
47.69\end{array}$ & 9.63 & 505 & 747 & 42.8 & 0.8682 \\
\hline $2 \mathrm{H}-2,140-150$ & 55 & 7.1 & 3.1 & 10.55 & 34.5 & $\begin{array}{l}7.62 \\
\end{array}$ & 14.50 & 548.6 & 16.41 & 472.4 & 10.96 & $\begin{array}{l}47.09 \\
47.30\end{array}$ & 8.99 & 501 & 1064 & $\begin{array}{l}4.0 \\
51.4\end{array}$ & 0.8611 \\
\hline $2 \mathrm{H}-5,140-150$ & 55 & 6.8 & 3.7 & 15.05 & 34.5 & 7.98 & 17.36 & 549.3 & 13.56 & 471.9 & 10.54 & 47.59 & 8.09 & 565 & 1233 & 87.6 & 0.8591 \\
\hline $3 \mathrm{H}-5,140-150$ & 55 & 8.2 & 4.9 & 24.55 & 34.5 & 7.98 & 18.29 & 550.0 & 10.40 & 471.0 & 10.58 & 46.88 & 6.91 & 636 & 1306 & 84.3 & 0.8563 \\
\hline $4 \mathrm{H}-5,140-150$ & 55 & 8.9 & 6.1 & 34.05 & 34.0 & 7.98 & 16.94 & 553.6 & 9.20 & 475.0 & 10.45 & 45.93 & 5.80 & 565 & 1302 & 28.8 & 0.8581 \\
\hline $5 \mathrm{H}-5,140-150$ & 55 & - & 7.2 & 43.55 & 34.0 & 8.16 & 18.75 & 553.4 & 8.20 & 477.9 & 10.17 & 44.91 & 5.30 & 602 & 1354 & 18.7 & 0.8637 \\
\hline $6 \mathrm{H}-5,140-150$ & 55 & 8.8 & 8.4 & 53.05 & 34.0 & 8.08 & 19.70 & 550.2 & 4.99 & 472.5 & 9.68 & 43.70 & 5.14 & 615 & 1447 & 13.7 & 0.8588 \\
\hline $7 \mathrm{H}-5,140-150$ & 55 & 8.9 & 9.6 & 62.55 & 34.0 & 8.14 & 21.79 & 551.0 & 2.99 & 473.6 & 9.46 & 42.43 & 5.43 & 611 & 1484 & 34.7 & 0.8595 \\
\hline $8 \mathrm{H}-5,140-150$ & 30 & 10.3 & 10.8 & 72.05 & 34.0 & 8.08 & 22.17 & 550.7 & 1.10 & 472.9 & 9.52 & 40.99 & 5.35 & 567 & 1625 & 19.6 & 0.8587 \\
\hline $9 \mathrm{H}-5,140-150$ & 55 & 8.9 & 12.0 & 81.55 & 33.5 & 7.85 & 21.85 & 549.5 & 0.29 & 471.5 & 8.24 & 40.47 & 5.63 & 628 & 1579 & 24.6 & 0.8580 \\
\hline $10 \mathrm{H}-5,135-150$ & 55 & 9.8 & 13.2 & 91.03 & 33.5 & 8.01 & 20.76 & 550.2 & 0.20 & 472.0 & 8.80 & 39.75 & 5.52 & 580 & 1701 & 15.5 & 0.8579 \\
\hline $11 \mathrm{H}-5,135-150$ & 55 & 9.8 & 14.4 & 100.53 & 33.5 & $\begin{array}{l}.0 .01 \\
7.96\end{array}$ & 19.84 & 548.2 & 0.14 & 469.4 & $\begin{array}{l}0.00 \\
9.14\end{array}$ & 39.10 & 5.80 & 370 & 1605 & 10.8 & 0.8563 \\
\hline $12 \mathrm{H}-5,135-150$ & 55 & $\begin{array}{r}7.0 \\
10.2\end{array}$ & $\begin{array}{l}15.6 \\
15.6\end{array}$ & 110.03 & 33.5 & 7.77 & 18.62 & 547.2 & 0.33 & 468.2 & 8.50 & 38.57 & 6.33 & 764 & 1542 & 34.1 & 0.8556 \\
\hline $13 \mathrm{H}-5,135-150$ & 55 & - & 16.7 & 119.53 & 32.0 & 7.78 & 15.69 & 550.4 & 2.21 & 471.7 & 8.40 & 38.47 & 6.73 & 775 & 1363 & 12.9 & 0.8570 \\
\hline $14 \mathrm{X}-5,135-150$ & 55 & - & 17.9 & 129.03 & 32.5 & 7.77 & 12.98 & 546.7 & 5.74 & 469.8 & 8.66 & 38.35 & 7.99 & 569 & 1268 & 8.2 & 0.8594 \\
\hline $15 \mathrm{X}-5,135-150$ & 55 & 9.3 & 19.1 & 138.63 & 32.5 & 7.62 & 11.04 & 546.9 & 9.24 & 470.5 & 8.72 & 39.04 & 9.58 & 887 & 1041 & 8.2 & 0.8602 \\
\hline $16 \mathrm{X}-5,135-150$ & 55 & - & 20.3 & 148.23 & 33.5 & 7.73 & 5.28 & 546.1 & 15.40 & 469.0 & 8.65 & 40.61 & 11.67 & 424 & 795 & 0.0 & 0.8588 \\
\hline $17 \mathrm{X}-5,135-150$ & 55 & - & 21.5 & 157.83 & 34.0 & 7.60 & 3.73 & 545.3 & 19.98 & 467.2 & 9.46 & 41.73 & 14.42 & 930 & 457 & 0.8 & 0.8568 \\
\hline $18 \mathrm{X}-1,135-150$ & 55 & - & 22.0 & 161.43 & 34.0 & 7.68 & 3.01 & 542.6 & 21.46 & 464.5 & 9.13 & 42.44 & 15.01 & 762 & 387 & 1.4 & 0.8561 \\
\hline $18 \mathrm{X}-2,135-150$ & 55 & - & 22.2 & 162.93 & 34.0 & 7.75 & 3.51 & 540.9 & 22.56 & 463.0 & 9.24 & 42.76 & 15.90 & 715 & 350 & 0.1 & 0.8559 \\
\hline
\end{tabular}


Table 15 (continued).

\begin{tabular}{|c|c|c|c|c|c|c|c|c|c|c|c|c|c|c|c|c|c|}
\hline $\begin{array}{l}\text { Core, section, } \\
\text { interval }(\mathrm{cm})\end{array}$ & $\begin{array}{l}\text { Volume } \\
(\mathrm{mL})\end{array}$ & $\begin{array}{l}\text { Squeeze T } \\
\left({ }^{\circ} \mathrm{C}\right)\end{array}$ & $\begin{array}{l}\text { In situ T } \\
\left({ }^{\circ} \mathrm{C}\right)\end{array}$ & $\begin{array}{l}\text { Depth } \\
\text { (mbsf) }\end{array}$ & $\begin{array}{l}\text { Salinity } \\
\text { (R.I.,\%) }\end{array}$ & $\mathrm{pH}$ & $\begin{array}{l}\text { Alkalinity } \\
\text { (meq/kg) }\end{array}$ & $\begin{array}{l}\text { Chlorinity } \\
\text { (mmol/kg) }\end{array}$ & $\begin{array}{c}\text { Sulfate } \\
(\mathrm{mmol} / \mathrm{kg})\end{array}$ & $\begin{array}{c}\mathrm{Na} \\
(\mathrm{mmol} / \mathrm{kg})\end{array}$ & $\begin{array}{c}\mathrm{K} \\
(\mathrm{mmol} / \mathrm{kg})\end{array}$ & $\begin{array}{c}\mathrm{Mg} \\
(\mathrm{mmol} / \mathrm{kg})\end{array}$ & $\begin{array}{c}\mathrm{Ca} \\
(\mathrm{mmol} / \mathrm{kg})\end{array}$ & $\begin{array}{c}\mathrm{Si} \\
(\mu \mathrm{mol} / \mathrm{kg})\end{array}$ & $\begin{array}{c}\mathrm{NH}_{3} \\
(\mu \mathrm{mol} / \mathrm{kg})\end{array}$ & $\begin{array}{c}\mathrm{PO}_{4} \\
(\mu \mathrm{mol} / \mathrm{kg})\end{array}$ & $\mathrm{Na} / \mathrm{Cl}$ \\
\hline $18 X-3,135-150$ & 55 & - & 22.4 & 164.43 & 34.0 & 7.80 & 2.86 & 540.0 & 23.02 & 463.8 & 9.57 & 41.89 & 15.86 & 681 & 298 & 0.0 & 0.8589 \\
\hline $18 X-4,135-150$ & 55 & - & 22.5 & 165.93 & 34.0 & 7.57 & 2.15 & 542.2 & 23.92 & 465.5 & 8.94 & 42.66 & 16.23 & 723 & 231 & 0.0 & 0.8585 \\
\hline $18 X-5,135-150$ & 55 & - & 22.7 & 166.98 & 34.0 & 7.75 & 1.83 & 540.0 & 24.32 & 463.1 & 9.62 & 42.51 & 16.39 & 508 & 191 & 0.0 & 0.8575 \\
\hline Basement at: & & & 22.8 & 167.80 & & & & & & & & & & & & & \\
\hline \multicolumn{18}{|c|}{ Basement age $=0.970 \mathrm{Ma}$} \\
\hline \multicolumn{18}{|l|}{ 168-1025A- } \\
\hline $1 \mathrm{H}-1,140-150$ & 55 & 7.6 & 2.3 & 1.45 & 35.0 & 7.81 & 4.43 & 541.1 & 26.86 & 470.50 & 11.79 & 48.71 & 9.77 & 499 & 107 & 8.6 & 0.8695 \\
\hline $1 \mathrm{H}-2,140-150$ & 55 & 7.8 & 2.9 & 2.95 & 35.0 & 7.68 & 6.46 & 544.2 & 23.28 & 469.60 & 11.26 & 48.31 & 9.86 & 476 & 374 & 16.6 & 0.8629 \\
\hline $1 \mathrm{H}-3,140-150$ & 55 & 7.8 & 3.5 & 4.45 & 35.0 & 7.86 & 7.72 & 544.4 & 20.70 & 467.30 & 11.24 & 47.65 & 9.84 & 468 & 565 & 8.6 & 0.8584 \\
\hline \multicolumn{18}{|l|}{ 168-1025B- } \\
\hline $1 \mathrm{H}-1,140-150$ & 55 & 6.1 & 2.3 & 1.45 & 35.0 & 7.72 & 4.45 & 543.1 & 26.60 & 471.33 & 11.54 & 49.07 & 9.86 & 491 & 196 & 15.1 & 0.8678 \\
\hline $1 \mathrm{H}-2,140-150$ & 55 & 6.6 & 2.9 & 2.95 & 35.0 & 7.90 & 6.38 & 542.1 & 23.97 & 467.86 & 11.14 & 48.79 & $\begin{array}{l}9.00 \\
9.92\end{array}$ & 449 & 374 & 17.6 & 0.8631 \\
\hline $1 \mathrm{H}-3,140-150$ & 55 & 6.8 & 3.5 & 4.45 & 35.0 & 7.81 & 8.87 & 543.9 & 21.16 & 469.63 & 11.23 & 47.40 & 9.71 & 481 & 565 & 17.6 & 0.8635 \\
\hline $2 \mathrm{H}-1,140-150$ & 55 & 7.2 & 4.2 & 6.45 & 34.5 & 7.80 & 13.14 & 547.1 & 15.69 & 472.18 & 10.52 & 45.03 & 9.43 & 512 & 997 & 33.1 & 0.8631 \\
\hline $2 \mathrm{H}-2,140-150$ & 55 & 7.3 & 4.8 & 7.95 & 34.5 & 7.69 & 14.31 & 546.2 & 14.36 & 471.38 & 10.59 & 44.31 & 9.31 & 514 & 1124 & 34.9 & 0.8630 \\
\hline $2 \mathrm{H}-3,140-150$ & 55 & 8.6 & 5.4 & 9.45 & 34.5 & 7.79 & 15.43 & 547.2 & 13.84 & 473.28 & 10.59 & 44.15 & 9.07 & 502 & 1238 & 38.5 & 0.8649 \\
\hline $2 \mathrm{H}-4,140-150$ & 55 & 13.2 & 5.9 & 10.95 & 34.5 & 7.90 & 16.42 & 551.4 & 12.94 & 479.53 & 10.93 & 42.86 & 8.76 & 478 & 1365 & 31.2 & 0.8697 \\
\hline $3 \mathrm{H}-5,140-150$ & 55 & 9.3 & 10.1 & 21.95 & 34.0 & 7.73 & 16.41 & 560.3 & 8.52 & 485.59 & 10.53 & 40.81 & 8.00 & 499 & 1696 & 31.2 & 0.8667 \\
\hline $4 \mathrm{H}-5,140-150$ & 55 & 11.4 & 13.7 & 31.45 & 33.5 & 7.88 & 11.15 & 556.2 & 12.16 & 484.73 & 10.38 & 38.36 & 9.92 & 604 & 1518 & 17.6 & 0.8715 \\
\hline $5 \mathrm{H}-5,140-150$ & 55 & 12.3 & 17.2 & 40.95 & 34.0 & 7.78 & & 560.5 & 13.70 & & 9.76 & 36.11 & 12.86 & 659 & 1334 & 3.9 & \\
\hline $6 \mathrm{H}-5,140-150$ & 55 & 13.6 & 20.8 & 50.45 & 34.5 & 7.83 & 4.63 & 559.5 & 16.81 & 485.79 & 8.86 & 32.90 & 18.65 & 579 & 1102 & 3.9 & 0.8683 \\
\hline $7 \mathrm{H}-5,140-150$ & 55 & 13.6 & 24.4 & 59.95 & 35.0 & 7.83 & 3.27 & 559.5 & 20.01 & 484.51 & $\begin{array}{l}7.80 \\
7.89\end{array}$ & 30.90 & 24.30 & 586 & 916 & 1.3 & 0.8660 \\
\hline $8 \mathrm{H}-5,140-150$ & 35 & - & 28.0 & 69.45 & 35.5 & 8.24 & 2.37 & 560.4 & 21.81 & 481.84 & 7.46 & 29.52 & 29.02 & 256 & 730 & 1.3 & 0.8598 \\
\hline $10 \mathrm{X}-1,135-150$ & 55 & 二 & 32.9 & 82.53 & 35.0 & $\begin{array}{l}0.24 \\
7.87\end{array}$ & 1.75 & 554.5 & 26.75 & $\begin{array}{l}401.04 \\
477.46\end{array}$ & 6.37 & 27.92 & 35.03 & 399 & 328 & 0.6 & 0.8611 \\
\hline $10 \mathrm{X}-5,135-150$ & 55 & 二 & 35.2 & 88.53 & 35.0 & $\begin{array}{l}1.01 \\
7.74\end{array}$ & 1.77 & 552.4 & 26.07 & 475.57 & 6.96 & 26.80 & 35.09 & 428 & 229 & $\begin{array}{l}.0 \\
1.1\end{array}$ & 0.8609 \\
\hline $11 \mathrm{X}-2,135-150$ & 55 & - & 37.1 & 93.63 & 35.0 & 7.44 & 0.93 & 549.5 & 25.95 & 471.46 & 7.10 & 26.61 & 35.28 & 426 & 146 & 0.3 & 0.8580 \\
\hline $11 \mathrm{X}-3,135-150$ & 55 & - & 37.7 & 95.13 & 35.0 & 7.49 & 0.94 & 549.4 & 27.31 & 471.16 & 6.98 & 27.15 & 36.26 & 460 & 118 & 0.5 & 0.8576 \\
\hline $11 \mathrm{X}-4,135-150$ & 55 & - & 38.2 & 96.63 & 34.5 & 7.73 & 0.92 & 547.0 & 26.70 & 466.58 & 7.31 & 27.33 & 36.39 & 394 & 96 & 0.5 & 0.8530 \\
\hline \multirow{2}{*}{\multicolumn{18}{|c|}{ Basement at: }} \\
\hline & & & & & & & & & & & & & & & & & \\
\hline
\end{tabular}

Notes: $\mathrm{T}=$ temperature R. $\mathrm{I}=$ refractive index $-\mathrm{C}=$ not determined. 

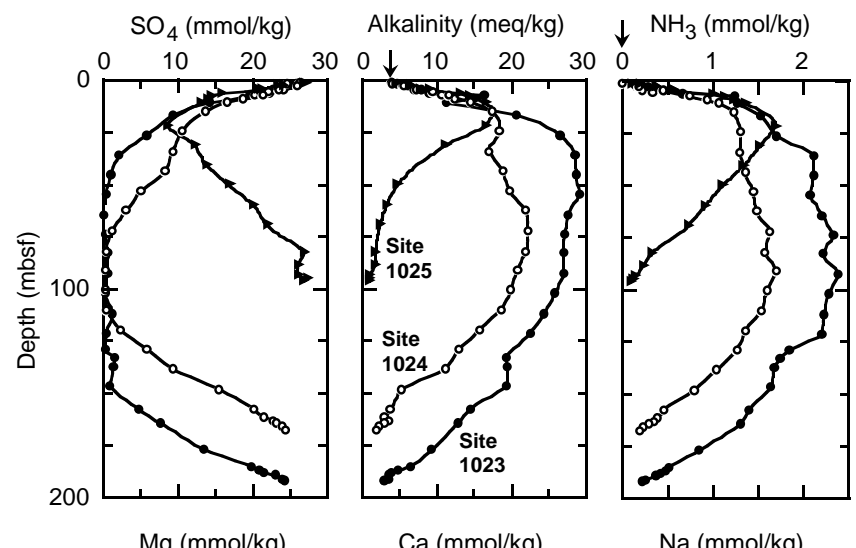

$\mathrm{Ca}(\mathrm{mmol} / \mathrm{kg})$

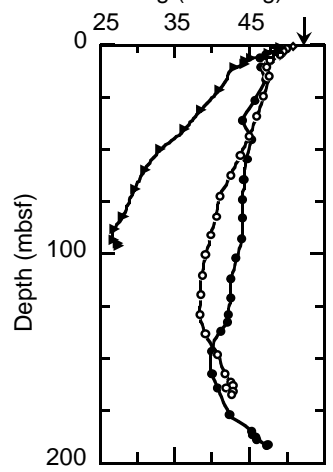

$\mathrm{pH}$
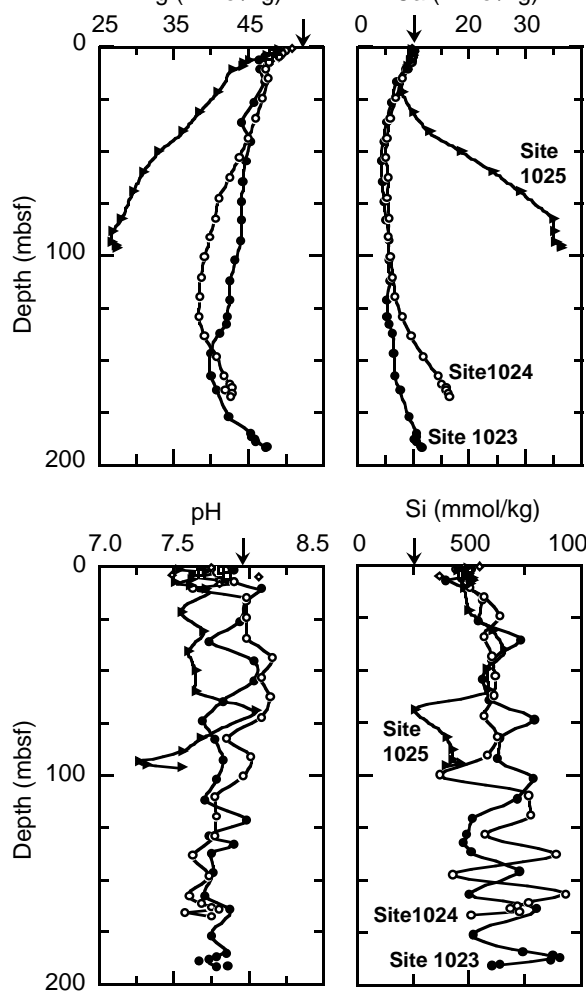

$\mathrm{Si}(\mathrm{mmol} / \mathrm{kg})$

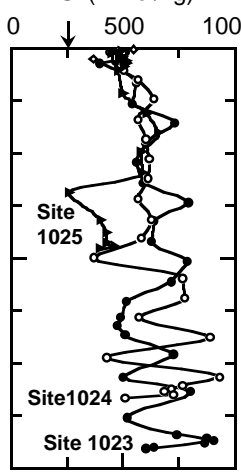

1000

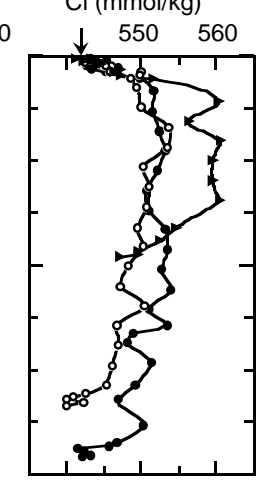

$\mathrm{Na}(\mathrm{mmol} / \mathrm{kg})$ $460 \downarrow 470 \quad 480$

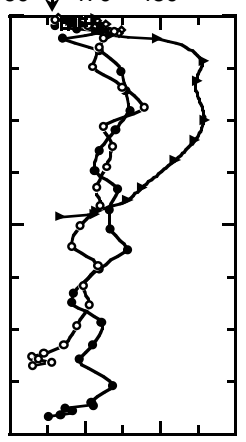

$\mathrm{P}(\mu \mathrm{mol} / \mathrm{kg})$
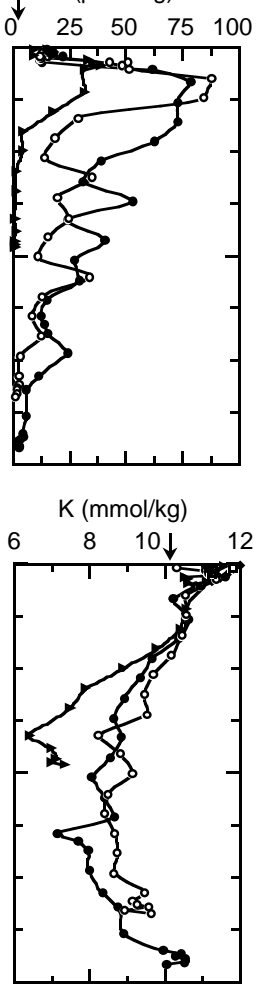

$\mathrm{Na} / \mathrm{Cl}(\mathrm{mol} / \mathrm{mol})$

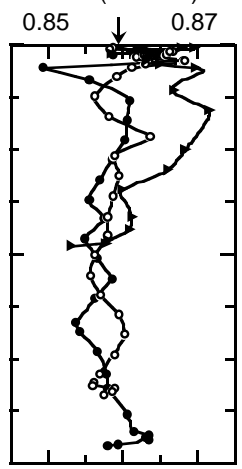

Figure 34. Composition of pore water from the Hydrothermal Transition sites. Arrows = the composition of bottom seawater. Solid circles $=$ Hole 1023A; open circles $=$ Holes $1024 \mathrm{~A}$ and $1024 \mathrm{~B} ;$ and solid triangles $=$ Holes 1025A and 1025B. contact with overlying bottom seawater and underlying basement fluids.

An added complication, though, is that the pore-water calcium profile shows that the $\mathrm{Ca}^{2+}$ depletion in this interval is less than predicted (Fig. 35). This mass balance approach ignores advective and diffusive transport that would carry some of the missing alkalinity away from the zone of precipitation and also supply $\mathrm{Ca}^{2+}$. It is also possible that alteration of sediment supplies some of the $\mathrm{Ca}^{2+}$ used in carbonate precipitation; it will be important to evaluate this in future work. Upward diffusion of methane into the sulfate reduction zone is another potentially complicating factor, as methane oxidation by sulfate is known to occur.

The third product of organic matter degradation that is modified by geochemical reactions is ammonia. Again considering organic matter stoichiometry, sediments from the Hydrothermal Transition sites have $\mathrm{C} / \mathrm{N}$ of about 9 (Fig. 36). However, $\mathrm{C} / \mathrm{N}$ ratios inferred from the pore-water sulfate and ammonia results are much higher, about 27 (Fig. 36). This most likely reflects an uptake of ammonia onto clay minerals by ion exchange. It is easy to show that this has a negligible effect on the bulk-sediment chemistry.
A separate class of reaction can be inferred from the pore-water profiles of the alkali metal and alkaline earth elements (Fig. 34). The composition of pore water at the three sites showed clear indications of reaction and diffusion in the sediment section. Magnesium concentrations at Sites 1023 and 1024 decrease with depth to minima at 130-160 mbsf, indicative of removal within the sediment column. Potassium shows similar behavior, except for an apparent increase in concentration at shallow depths below the seafloor, a well-known artifact of pore-water sampling. The profiles from Site 1025 are more extreme, being influenced by fluid flow (see below).

\section{Diagenesis in Turbidites}

Sediment at the Hydrothermal Transition sites consists of sequences of rhythmic sand and silt turbidites interbedded with hemipelagic mud that overlie turbidite-free hemipelagic mud (see "Lithostratigraphy" section, this chapter). Pore-water silica concentrations (Fig. 34) appear to be affected by these complex lithologic variations. Unlike most other species that show depth profiles that are smoothed by the effects of diffusion, the silica profiles appear as smooth curves 

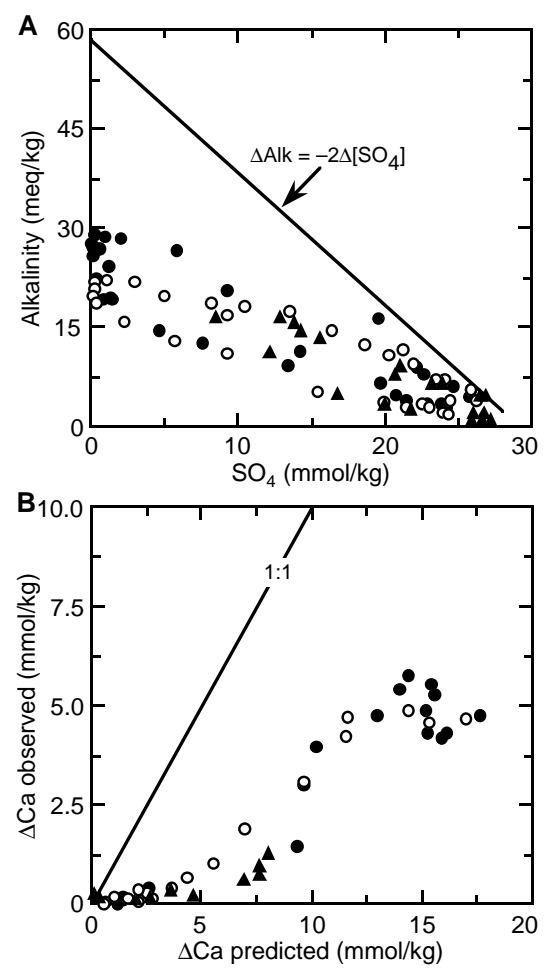

Figure 35. A. Sulfate vs. alkalinity in pore waters from the Hydrothermal Transition Transect. The solid line is the correlation expected if alkalinity behaves conservatively. B. Observed Ca depletion vs. predicted Ca depletion. Observed depletion is the difference between measured $\mathrm{Ca}$ and seawater concentration for depths shallower than the sulfate minimum at each site. Predicted depletion was calculated stoichiometrically by assuming that all the alkalinity deficiency in $\mathrm{A}$ is lost as $\mathrm{CaCO}_{3}$. Solid circles $=$ Hole 1023A; open circles $=$ Holes 1024A and 1024B; and solid triangles $=$ Holes $1025 \mathrm{~A}$ and 1025B.

upon which extrema are imposed. Phosphate shows similar patterns (Fig. 34). Such extrema can be maintained only by local precipitation-dissolution reactions. A test of the significance of such features will require detailed mineralogic studies.

\section{The Influence of Fluid Flow}

Vertical advection through the sediment column was evident only in Hole 1025B, where slow upward seepage of water is indicated by a systematic curvature in the profiles of calcium, magnesium, alkalinity, and, perhaps, sulfate (Fig. 34). Some degree of superhydrostatic pressure in basement at this site was also suggested by the observed discharge from Hole $1025 \mathrm{C}$, which was drilled through the sediment and about $5 \mathrm{~m}$ into upper basement. The discharge was seen with the VIT camera at the time of reentry with the 103/4-in casing string (see "Operations" section, this chapter).

Evidence for fluid flow within basement comes from two sources. The first is the reversal in concentration of many dissolved species with depth, back toward seawaterlike values near basement. This is seen, for example, for sulfate, alkalinity, and ammonia in Figure 34 and must reflect diffusive exchange between the sediment pore water and an underlying basement-fluid reservoir. This reversal has been observed in other situations where relatively unaltered seawater flows through basement (e.g., Baker et al., 1991).

The second source of evidence comes from chlorinity. The commonly observed increase from the concentration in present-day bot-
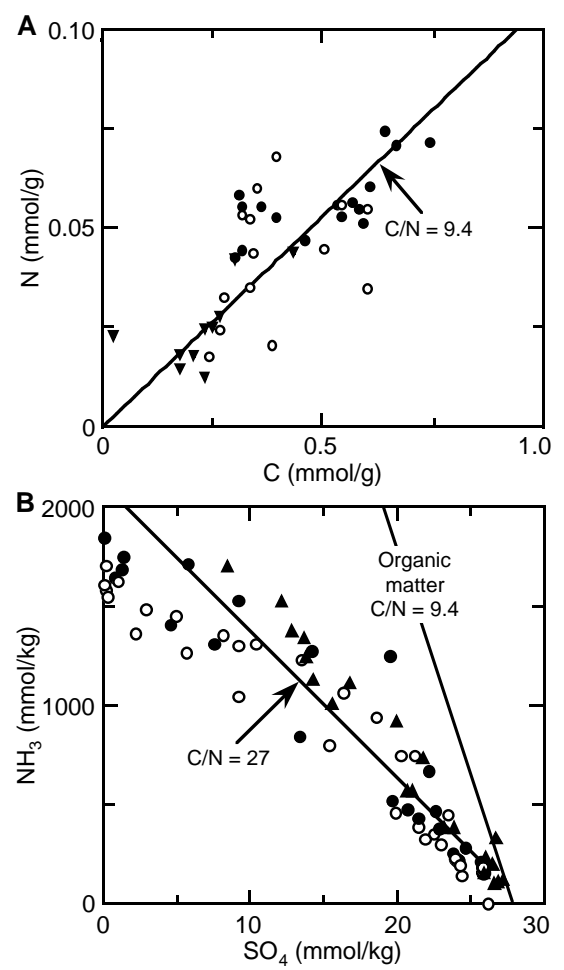

Figure 36. A. Organic carbon vs. nitrogen in sediment from the Hydrothermal Transition Transect (see "Organic Geochemistry" section, this chapter). The solid line is the linear regression line when all the data are considered together. B. Sulfate vs. ammonia in pore waters. The solid lines show the measured regression line and the equivalent $\mathrm{C} / \mathrm{N}$ ratio (from stoichiometry) and the line representing the sediment data. Solid circles $=$ Hole 1023A; open circles $=$ Holes $1024 \mathrm{~A}$ and 1024B; and solid triangles $=$ Holes $1025 \mathrm{~A}$ and $1025 B$.

tom seawater of $542 \mathrm{mmol} / \mathrm{kg}$ at the seafloor to elevated values of relic Pleistocene bottom water within a few tens of meters below the seafloor was seen at all three sites. Concentrations decrease again in samples from greater depths, however, back to values identical to present-day bottom seawater in samples from Holes 1023A and $1024 \mathrm{~B}$, and to only a slightly elevated value $(547 \mathrm{mmol} / \mathrm{kg})$ in samples from Hole 1025B (Fig. 34). A simple interpretation of these low chlorinity values is that the water has a residence time in basement of only a few thousand years, even at the site most distant from outcrop.

\section{Water/Rock Reactions Within the Basement}

The composition of basement waters, inferred from the porewater composition in basal sediments, reveals systematic changes with increasing temperature and distance from outcrop in some elemental concentrations (Fig. 34). Changes are most apparent in magnesium and calcium, which are particularly reactive in basement. Concentrations in samples from Hole $1023 \mathrm{~A}$ were $47 \mathrm{mmol} / \mathrm{kg} \mathrm{Mg}$ and $12 \mathrm{mmol} / \mathrm{kg} \mathrm{Ca}$, only slightly changed from seawater. At Site 1025 , the site farthest from outcrop, $\mathrm{Mg}$ fell to $27 \mathrm{mmol} / \mathrm{kg}$, and $\mathrm{Ca}$ rose to more than $36 \mathrm{mmol} / \mathrm{kg}$. Changes are also apparent for other pore-water constituents, such as alkalinity and sulfate. Interestingly, ammonia concentrations are much higher than those in seawater for samples from Site 1023 and decrease with increasing distance from outcrop. Phosphate is also depleted in the pore waters (Fig. 34) relative to other products of organic matter degradation and has been removed from solution within basement (Wheat et al., 1996). These re- 
sults indicate that seawater is chemically modified by interaction with basalt during transport in basement.

\section{Conclusions}

The pore waters from the Hydrothermal Transect sites have been modified from seawater composition by (1) diagenetic reactions within the sediment involving organic matter degradation, (2) associated precipitation of pyrite and calcite, and (3) removal of ammonia by ion exchange. There is evidence also for removal of $\mathrm{Mg}$ and $\mathrm{K}$ by fluid/mineral reactions, and there may be localized silica dissolution and precipitation. The sediment pore water at all of the sites is influenced by the flow of water through basement and, for Site 1025, by slow upward advection through the sediment column. Over the $17 \mathrm{~km}$ of the transect, the composition of the basement fluid changes significantly from seawater composition.

\section{ORGANIC GEOCHEMISTRY}

Shipboard organic geochemical analyses of sediment from Sites 1023,1024 , and 1025 include measurements of volatile hydrocarbons, inorganic carbon, total carbon, sulfur, nitrogen, hydrogen, and Rock-Eval pyrolysis. The instrumentation and procedures are summarized in the "Methods" chapter (this volume).

\section{Volatile Hydrocarbons}

Volatile hydrocarbon gases $\left(\mathrm{C}_{1}-\mathrm{C}_{3}\right)$ were continuously measured in the sediments as part of the shipboard safety and pollution monitoring program. The results are listed in Table 16 and illustrated in Figure 37 . The hydrocarbon gas contents are predominantly methane. Higher molecular weight hydrocarbons were detected in only two samples from Hole 1023A. There is a good correlation between dissolved sulfate concentration (Fig. 37) and methane content in samples from Holes 1023A and 1024B. In the near-surface zone, characterized by sulfate reduction, methane concentrations are at or below background values. These values increase with depth as dissolved sulfate concentrations decrease and remain high down to depths at which sulfate concentrations start to increase again. This type of sulfate-methane segregation is typical of marine sediment (Claypool and Kaplan, 1974) and indicates that the primary source of the methane is bacterial methanogenesis. As seen in Figure 37, the response of the methanogenic bacteria to changes in sulfate concentration is very rapid. The onset of methanogenesis occurs in samples from Holes 1023A and 1024B at 55 and 80 mbsf, respectively. In contrast to Sites 1023 and 1024, headspace methane concentrations in Hole $1025 \mathrm{~B}$ samples remain low with increasing depth, which is consistent with the relatively high dissolved sulfate concentrations in the pore waters in Hole 1025B.

\section{Organic Carbon}

Total organic carbon (TOC) contents are relatively low in samples from Sites 1023, 1024, and 1025, varying typically between 0.2 and 0.8 wt\% (Table 17 on CD-ROM, back pocket; Fig. 38). TOC concentrations are notably lower (average about $0.3 \mathrm{wt} \%$ ) in samples from Hole 1025B than from Holes 1023A and 1024B and decrease slightly with depth. In core from the upper $50 \mathrm{~m}$ of Hole 1023A, TOC values decrease with depth and reach minimum values at the base of the sulfate reduction zone (see "Fluid Geochemistry" section, this chapter). This initial decrease is followed by an abrupt increase to slightly higher TOC values that remain relatively constant to the bottom of the hole. The variations in the downhole TOC profile for Hole 1023A are similar to the TOC depth trend for Hole 1027B (see "Rough Basement Transect" chapter, this volume).
Table 16. Headspace composition data from Sites 1023, 1024, and 1025.

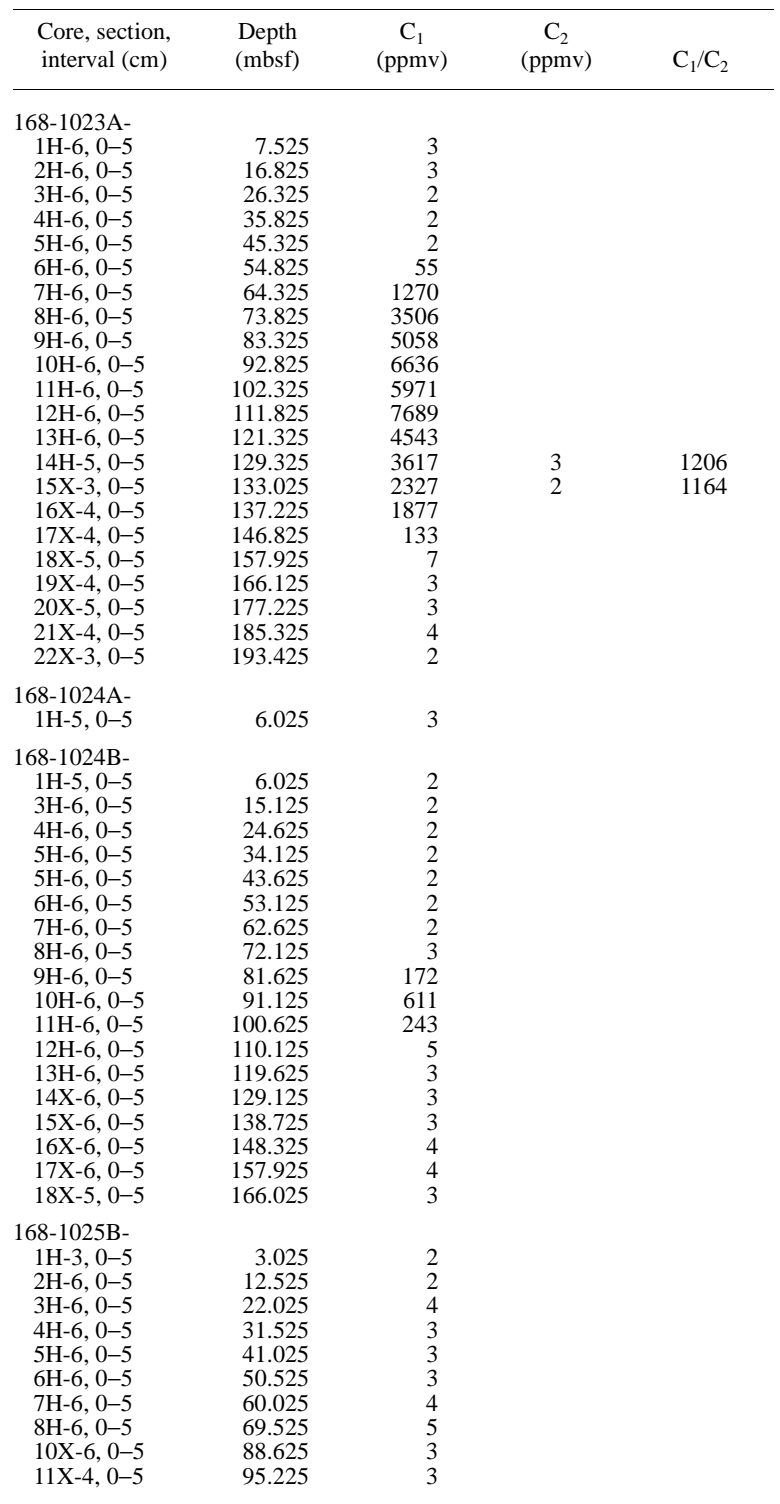

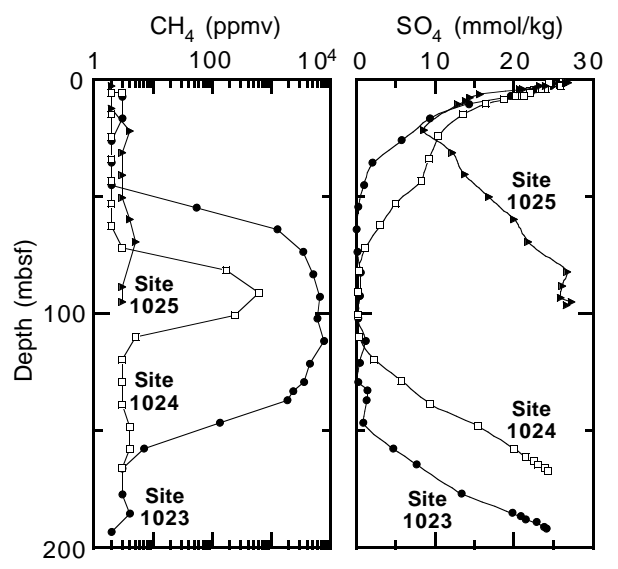

Figure 37. Methane and dissolved sulfate profiles for Sites 1023, 1024, and 1025 . 


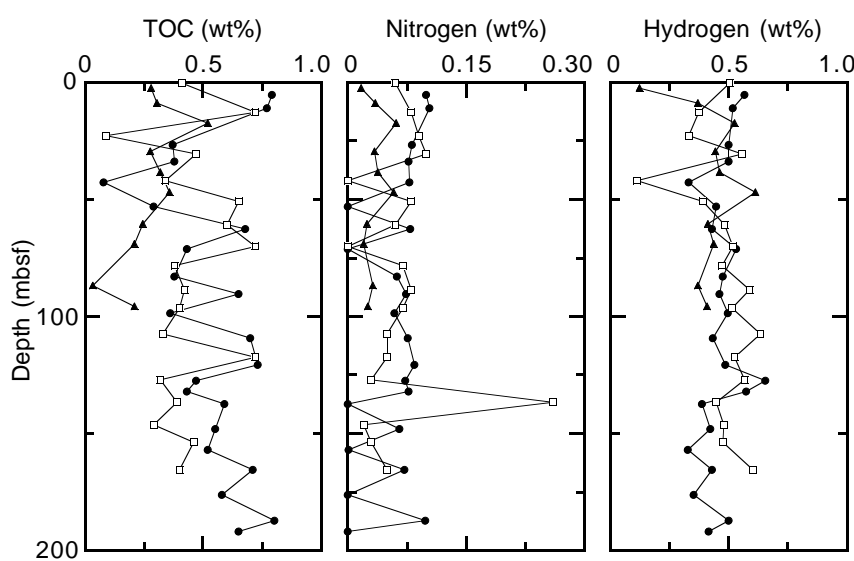

Figure 38. Depth distribution of total organic carbon, total nitrogen, and total hydrogen in sediment from Sites 1023, 1024, and 1025. Solid circles $=$ Hole $1023 \mathrm{~A}$; open squares $=$ Hole 1024B; and solid triangles $=$ Hole 1025B .

\section{Sulfur, Nitrogen, and Hydrogen}

The abundance of total sulfur, nitrogen, and hydrogen in sediment from Holes 1023A, 1024B, and 1025B are summarized in Table 17 on CD-ROM (back pocket). The data for total sulfur in Table 17 should only be used as an approximation of the total sulfur content of the sediments because it was not possible to obtain precise and reproducible sulfur determinations during Leg 168. The concentration profiles of total hydrogen (Fig. 38) in samples from Sites 1023, 1024, and 1025 show downhole fluctuations within a narrow range between 0.33 and $0.66 \mathrm{wt} \%$. No major depth trends or changes in hydrogen content were recorded. Several samples from Hole 1023A and two samples from Hole 1024B have no detectable amounts of nitrogen. These samples fall within two intervals between 41-71 and 137-192 mbsf. At Site 1025B, the total nitrogen and hydrogen contents correlate broadly with TOC contents. This correlation between hydrogen, nitrogen, and TOC contents can also be seen in some intervals from Holes 1024B and 1025B.

\section{Organic Matter Type: C/N Ratios and Rock-Eval Pyrolysis}

To characterize the organic matter, $\mathrm{C} / \mathrm{N}$ ratio and Rock-Eval hydrogen and oxygen indices were used. The correspondence of total organic carbon with total nitrogen content is illustrated in Figure 39. The average $\mathrm{C} / \mathrm{N}$ ratio for all three sites is 9.8 , indicating a mixed marine/terrestrial organic source, with the former richer in nitrogen (Emerson and Hedges, 1988). The fluctuations in $\mathrm{C} / \mathrm{N}$ ratio with depth are similar for samples from Holes 1023A and 1024B, suggesting an episodic supply of terrestrial organic matter or a selective degradation of labile nitrogen-containing compounds in some intervals. Rock-Eval pyrolysis was performed on selected organic carbon-rich samples from Holes 1023A and 1024B (Table 18). Based on calculated hydrogen and oxygen indices, the organic matter is derived from a terrestrial source (Fig. 40). This is not in agreement with the source determination based on $\mathrm{C} / \mathrm{N}$ ratios. However, the hydrogen index tends to be lowered if organic carbon content is low or if the mineral matrix effect is large (e.g., clay mineral content is high), and the data set could probably be shifted upward closer to the type II kerogen area.

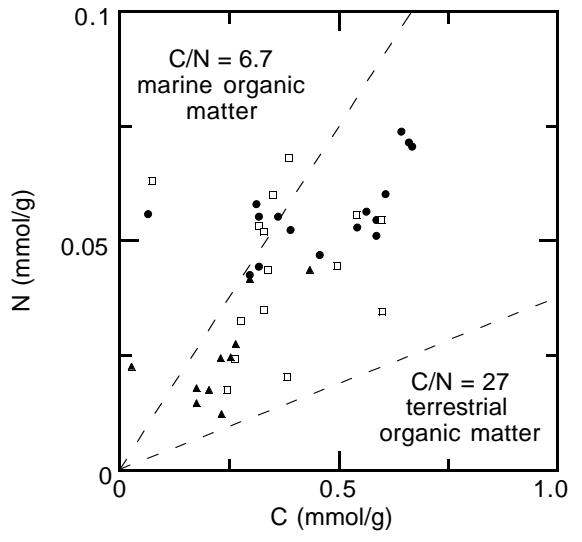

Figure 39. Total nitrogen vs. total organic carbon in sediment from Sites 1023, 1024, and 1025. Solid circles = Hole 1023; open squares = Hole 1024B; and solid triangles $=$ Hole 1027B.

\section{PHYSICAL PROPERTIES Sediment Properties}

Physical properties were measured continuously with the multisensor track (MST) and on discrete samples from cores recovered from Sites 1023, 1024, and 1025. The results are summarized in Figure 41. Based on the visual core descriptions, the data were separated into mud and sand. Averages, standard deviations, and the number of measurements are listed according to this separation in Table 19 and are discussed in more detail below. To assess a possible sampling bias, the total thickness of recovered sand relative to the thickness of the recovered sediment section was compared to the number of measurements in sand relative to the total number of measurements (Table 20). Sand layers are well represented according to their abundance in core from all holes, based on MST measurements. A sampling bias in thermal conductivity determinations was detected only for Hole 1025C. The discrete sampling for index properties (IP) and digital sonic velocimeter (DSV) measurements is biased toward an oversampling of mud (Table 21 on CD-ROM, back pocket). For these properties, a simple average of all measurements does not represent the mean for the drilled section; a weighted average must be calculated to account for the relative proportions of mud and sand layers.

Some physical properties measurements at this site appear to be affected by core disturbances associated with the switch from APC to XCB coring at 130.0, 131.2, and $71.5 \mathrm{mbsf}$ for Holes 1023A, 1024B, and $1025 \mathrm{~B}$, respectively. Although there often is a change in sediment properties that necessitates a change in coring method, the abrupt offsets in some physical properties (e.g., bulk density at Site 1023) may reflect greater core disturbance during XCB coring.

\section{Multisensor Track Measurements}

Magnetic susceptibility (MS) data were used to identify finegrained layers between coarser turbidite bases. Sample clusters were taken in the fine-grained layers. Figure 42 illustrates the MST and gamma-ray attenuation porosity evaluator (GRAPE) record for a typical $1.5-\mathrm{m}$ section from Hole 1023A that contained coarse-grained turbidite bases grading into finer material. The correlation between MS and GRAPE data with turbidites has been well documented (e.g., Sager and Hall, 1990). Figure 43 shows a crossplot of MS and GRAPE bulk density. Mud and sand data separate into distinct 
Table 18. Results of Rock-Eval pyrolysis on samples from Sites 1023 and 1024.

\begin{tabular}{|c|c|c|c|c|c|c|c|c|c|c|c|c|}
\hline $\begin{array}{l}\text { Core, section, } \\
\text { interval }(\mathrm{cm})\end{array}$ & $\begin{array}{l}\text { Depth } \\
\text { (mbsf) }\end{array}$ & $\begin{array}{l}\text { Weight } \\
\text { (mg) }\end{array}$ & $\begin{array}{l}\mathrm{T}_{\max } \\
\left({ }^{\circ} \mathrm{C}\right)\end{array}$ & $\mathrm{S}_{1}$ & $\mathrm{~S}_{2}$ & $\mathrm{~S}_{3}$ & PI & $\mathrm{S}_{2} / \mathrm{S}_{3}$ & $\mathrm{PC}$ & $\begin{array}{l}\text { TOC } \\
(\mathrm{wt} \%)\end{array}$ & $\mathrm{HI}$ & OI \\
\hline \multicolumn{13}{|l|}{ 168-1023A- } \\
\hline $7 \mathrm{H}-4,131-132$ & 62.61 & 100.72 & 436 & 0.07 & 0.10 & 1.88 & 0.44 & 0.05 & 0.01 & 0.68 & 14 & 276 \\
\hline $8 \mathrm{H}-4,39-40$ & 71.19 & 100.21 & 386 & 0.02 & 0.19 & 0.65 & 0.10 & 0.29 & 0.01 & 0.43 & 44 & 151 \\
\hline $10 \mathrm{H}-4,61-62$ & 90.41 & 100.64 & 530 & 0.02 & 0.41 & 0.70 & 0.05 & 0.58 & 0.03 & 0.65 & 63 & 107 \\
\hline $12 \mathrm{H}-4,52-53$ & 109.30 & 100.26 & 481 & 0.03 & 0.32 & 0.59 & 0.09 & 0.54 & 0.02 & 0.70 & 45 & 84 \\
\hline $13 \mathrm{H}-5,76-77$ & 120.60 & 100.74 & 373 & 0.01 & 0.18 & 0.20 & 0.06 & 0.90 & 0.01 & 0.73 & 24 & 27 \\
\hline $16 \mathrm{H}-4,18-22$ & 137.40 & 100.54 & - & 0.01 & 0.27 & 0.59 & 0.04 & 0.45 & 0.02 & 0.59 & 45 & 100 \\
\hline $17 X-4,110-111$ & 147.90 & 100.19 & - & 0.02 & 0.44 & 0.32 & 0.04 & 1.37 & 0.03 & 0.55 & 80 & 58 \\
\hline $19 X-3,95-96$ & 165.60 & 100.43 & 458 & 0.03 & 0.40 & 0.58 & 0.07 & 0.68 & 0.03 & 0.71 & 56 & 81 \\
\hline $20 X-4,30-31$ & 176.00 & 100.70 & - & 0.03 & 0.39 & 0.28 & 0.07 & 1.39 & 0.03 & 0.58 & 67 & 48 \\
\hline $21 X-5,33-34$ & 187.10 & 100.20 & 387 & 0.10 & 0.21 & 0.76 & 0.33 & 0.11 & 0.02 & 0.80 & 26 & 220 \\
\hline $22 \mathrm{X}-2,24-25$ & 191.70 & 100.30 & 322 & 0.06 & 0.08 & 0.45 & 0.43 & 0.05 & 0.01 & 0.65 & 12 & 223 \\
\hline \multicolumn{13}{|l|}{ 168-1024B- } \\
\hline $2 \mathrm{H}-4,48-49$ & 12.58 & 100.44 & 371 & 0.06 & 0.24 & 1.00 & 0.20 & 0.24 & 0.02 & 0.72 & 33 & 138 \\
\hline $6 \mathrm{H}-4,79-81$ & 50.89 & 100.45 & 505 & 0.05 & 0.55 & 0.67 & 0.08 & 0.82 & 0.05 & 0.65 & 84 & 103 \\
\hline $7 \mathrm{H}-4,111-112$ & 60.71 & 100.54 & - & 0.01 & 0.46 & 0.32 & 0.02 & 1.43 & 0.03 & 0.60 & 76 & 53 \\
\hline $8 \mathrm{H}-4,97-98$ & 70.07 & 100.32 & 528 & 0.03 & 0.51 & 0.40 & 0.06 & 1.27 & 0.04 & 0.72 & 70 & 55 \\
\hline $13 \mathrm{H}-4,81-82$ & 117.41 & 100.90 & - & 0.08 & 0.60 & 0.81 & 0.12 & 0.74 & 0.05 & 0.72 & 83 & 112 \\
\hline
\end{tabular}

Note: $\mathrm{PI}=$ production index $=\mathrm{S}_{2} /\left(\mathrm{S}_{1}+\mathrm{S}_{2}\right), \mathrm{PC}=$ pyrolyzed carbon $=0.083\left(\mathrm{~S}_{1}+\mathrm{S}_{2}\right)$, TOC $=$ total organic carbon, $\mathrm{HI}=\mathrm{hydrogen}$ index, and $\mathrm{OI}=$ oxygen index. $-=$ not well defined.

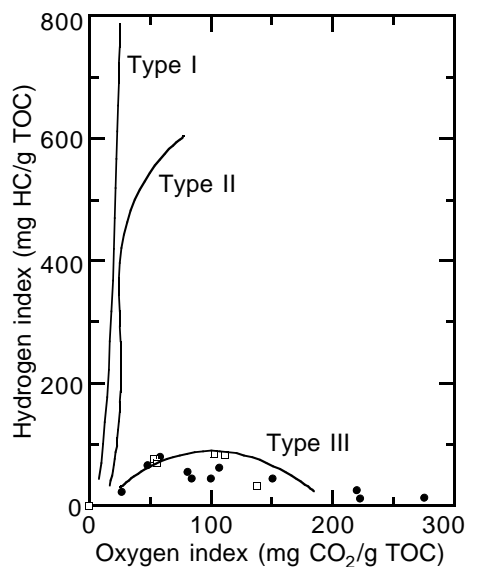

Figure 40. Hydrogen index plotted vs. oxygen index. Solid circles $=$ Hole $1023 \mathrm{~A}$; open squares $=$ Hole $1024 \mathrm{~B}$.

groups with the sand having greater bulk density and greater magnetic susceptibility.

GRAPE bulk density values are systematically higher than those measured on discrete index property samples for the upper $100 \mathrm{mbsf}$ of each hole, and the offset is proportional to the porosity. Figure 44 compares bulk density values for Hole 1023A and illustrates an offset of $5 \%-15 \%$. One would expect the bulk density value determined from a full core to be lower than the value measured from a discrete IP sample because full cores commonly include voids, cracks, drilling slurry, and gas bubbles from core expansion, whereas the IP samples are collected away from these disturbances. The cause of the offset is believed to reside in the MST processing software, which does not include the corrections suggested by Boyce (1976). Because these corrections require knowledge of the grain densities of the material measured, we have chosen not to correct the GRAPE data; however, this correction could be made once more detailed mineralogical data are available.
Natural gamma-ray (NGR) records show no systematic differences between sand and mud. However, NGR profiles for each hole at these sites show a zone at 30-50 mbsf of varying thickness where there is a general increase in natural gamma radiation (see Fig. 41). This record may be useful for hole-to-hole correlations (e.g., Hoppie et al., 1994).

The $P$-wave measurements made by the MST are of widely varying quality. The $30 \%$ intensity data exclusion criterion typically eliminates about $50 \%$ of the data. Although the remaining data contain a higher percentage of reasonable values, there is still some question as to the overall reliability of these measurements (see "Physical Properties" section, "Rough Basement Transect" chapter, this volume).

\section{DSV P-Wave Velocity}

DSV measurements reveal isotropic conditions in sediment from Holes 1023A and 1024B and a 5\% anisotropy in core from Hole 1025B (Fig. 45). Post-cruise investigations on whole-round cores may help to address the cause of this local anisotropy.

The correlation between porosity and $P$-wave velocity at the Hydrothermal Transition sites is discussed in context with Sites 1026 and 1027 in the "Physical Properties" section of the "Rough Basement Transect" chapter (this volume), based on a larger range of depths and values for both properties.

\section{Thermal Conductivity}

Thermal conductivity values were obtained from full-space needle-probe measurements on all cores recovered from Holes $1023 \mathrm{~A}, 1024 \mathrm{~B}$, and 1025B. The RCB cores from Hole 1025C were measured using a half-space line source in the split liner.

The correlation between porosity and thermal conductivity is shown in Figure 46. The data are scattered but suggest a matrix conductivity of about $3 \mathrm{~W} /(\mathrm{m} \cdot \mathrm{K})$. This value is at the lower limit of matrix thermal conductivities ranging from 3.1 to $3.9 \mathrm{~W} /(\mathrm{m} \cdot \mathrm{K})$ that were determined on sediment collected in the region during Leg 139 (see Davis, Mottl, Fisher, et al., 1992). In general, sands are characterized by the highest conductivities and the lowest porosities, yet a distinction between the matrix conductivities cannot be made. 


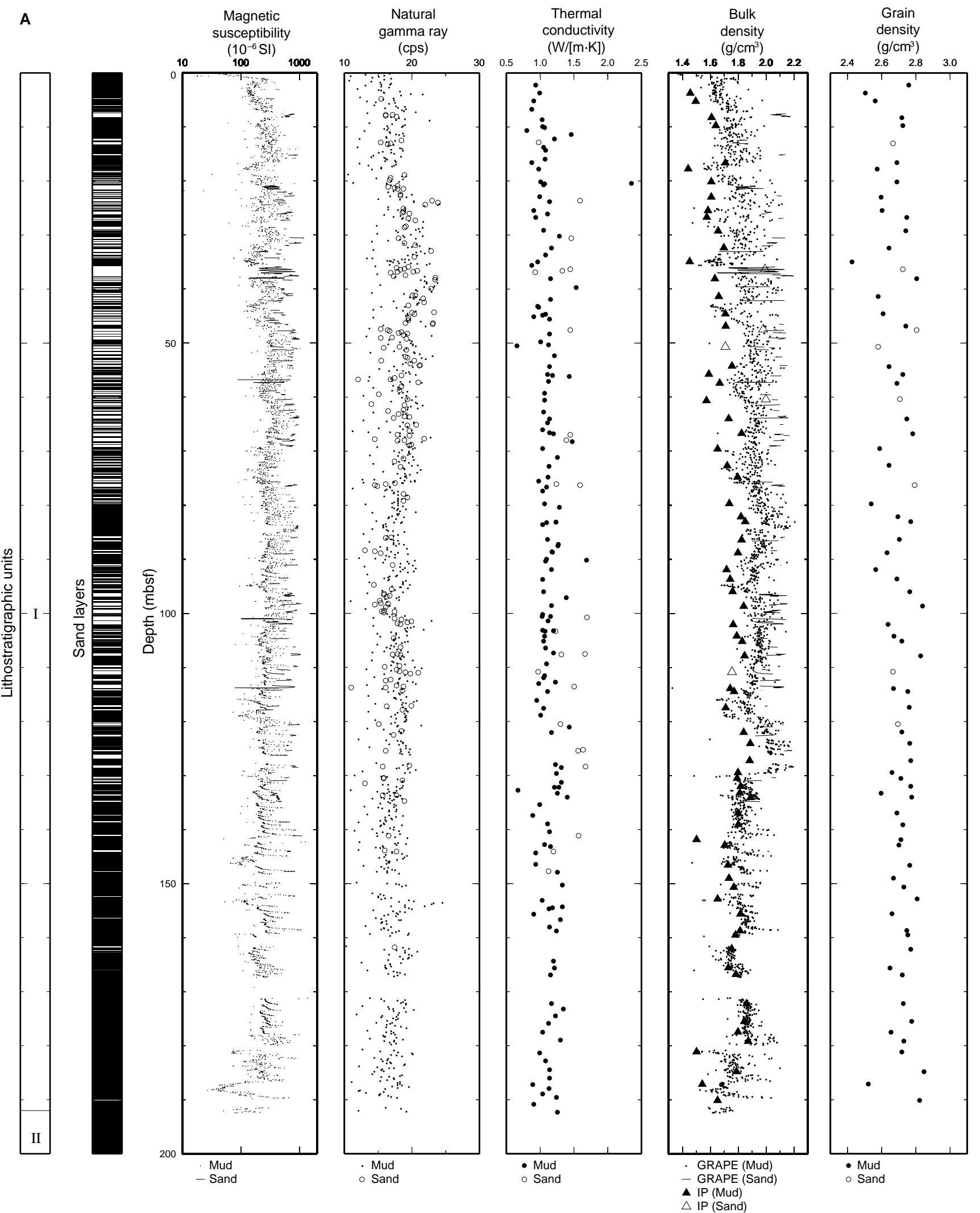

Figure 41. Summary plots for physical properties with lithostratigraphic units and identified sand layers (white) for (A) Hole 1023A, (B) Hole 1024B, and (C) Holes 1025B and 1025C. Below 100 mbsf, all data points in (C) are from measurements of basalt rather than sediment. 


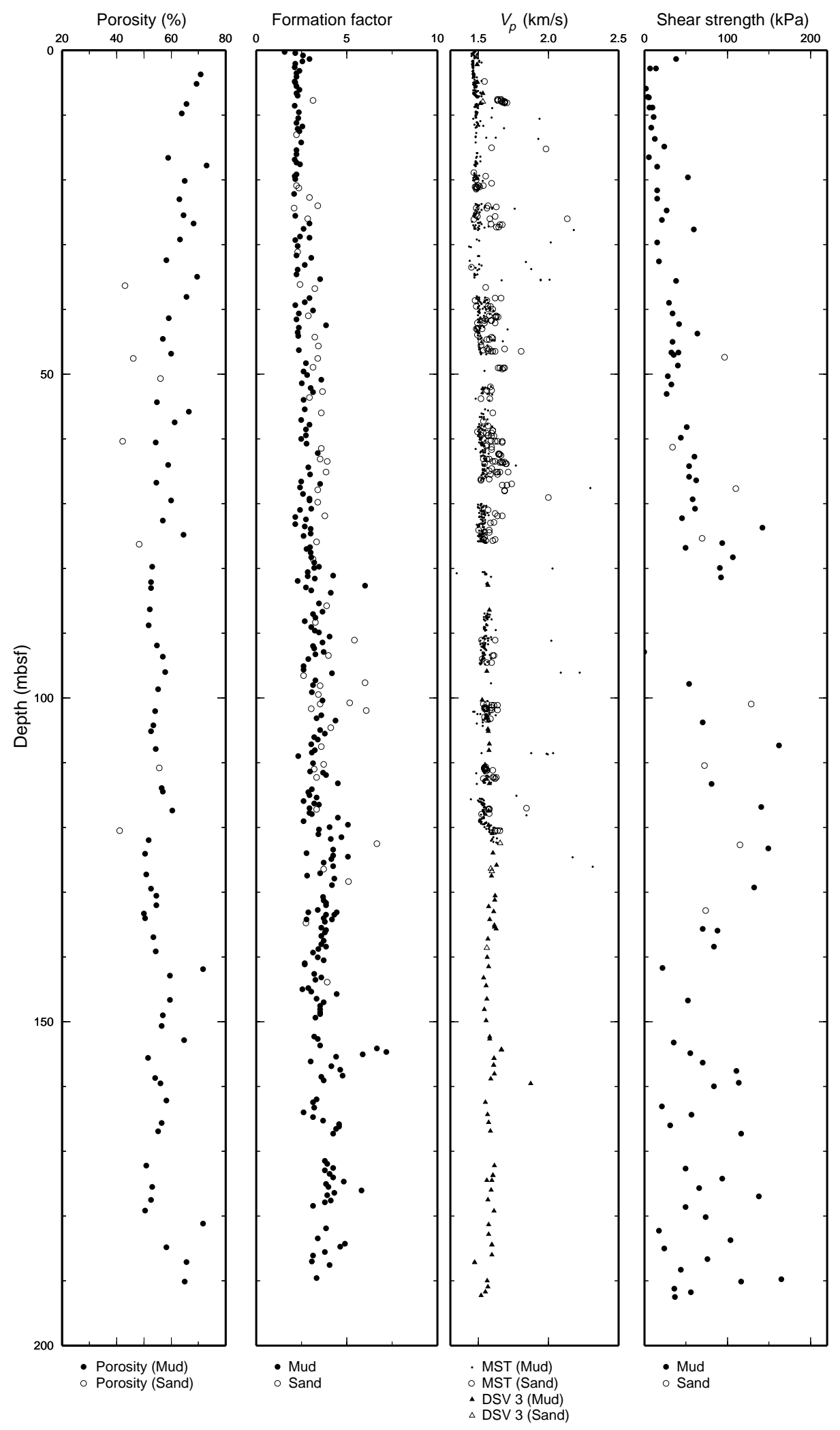

Figure 41 (continued). 

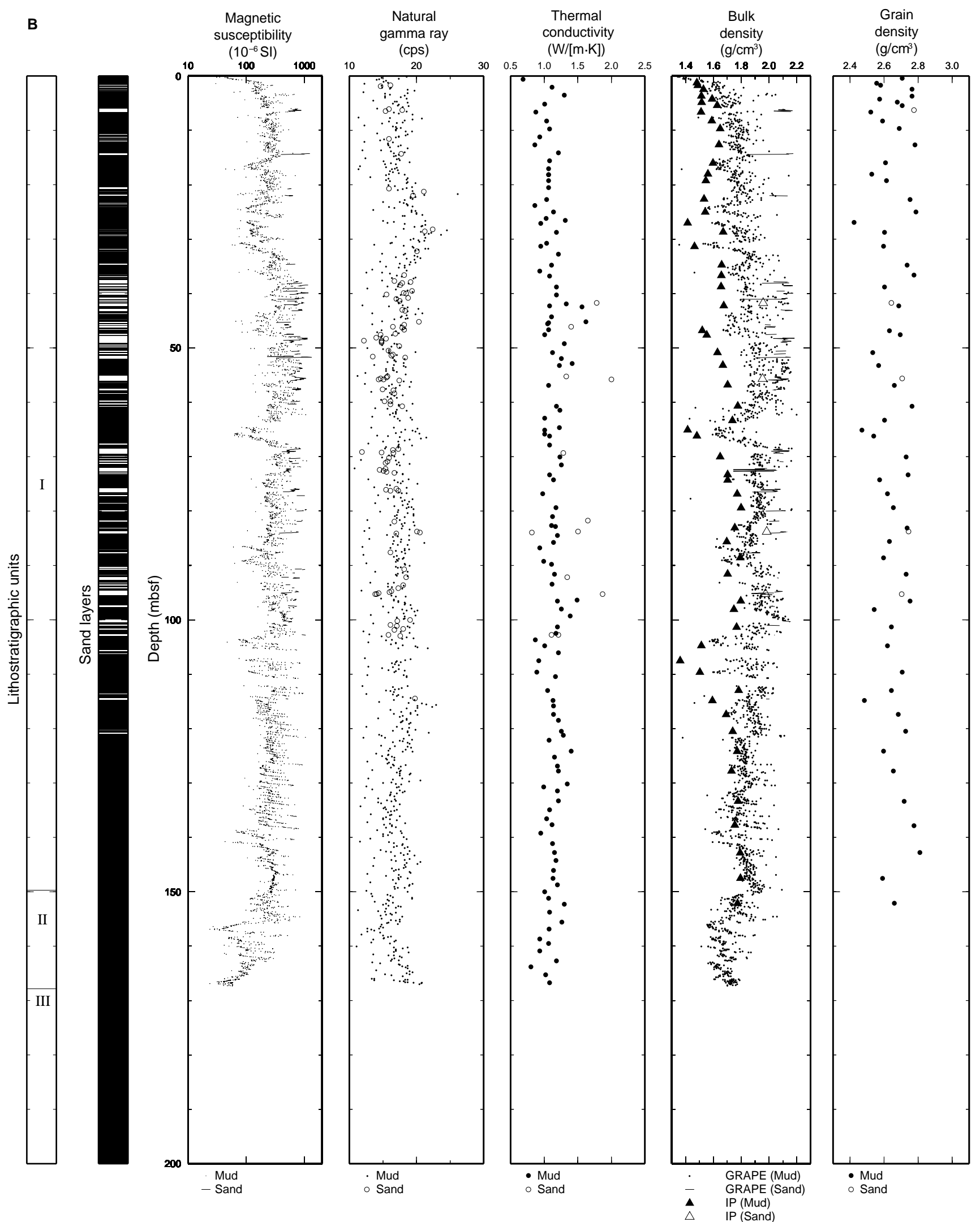

Figure 41 (continued). 


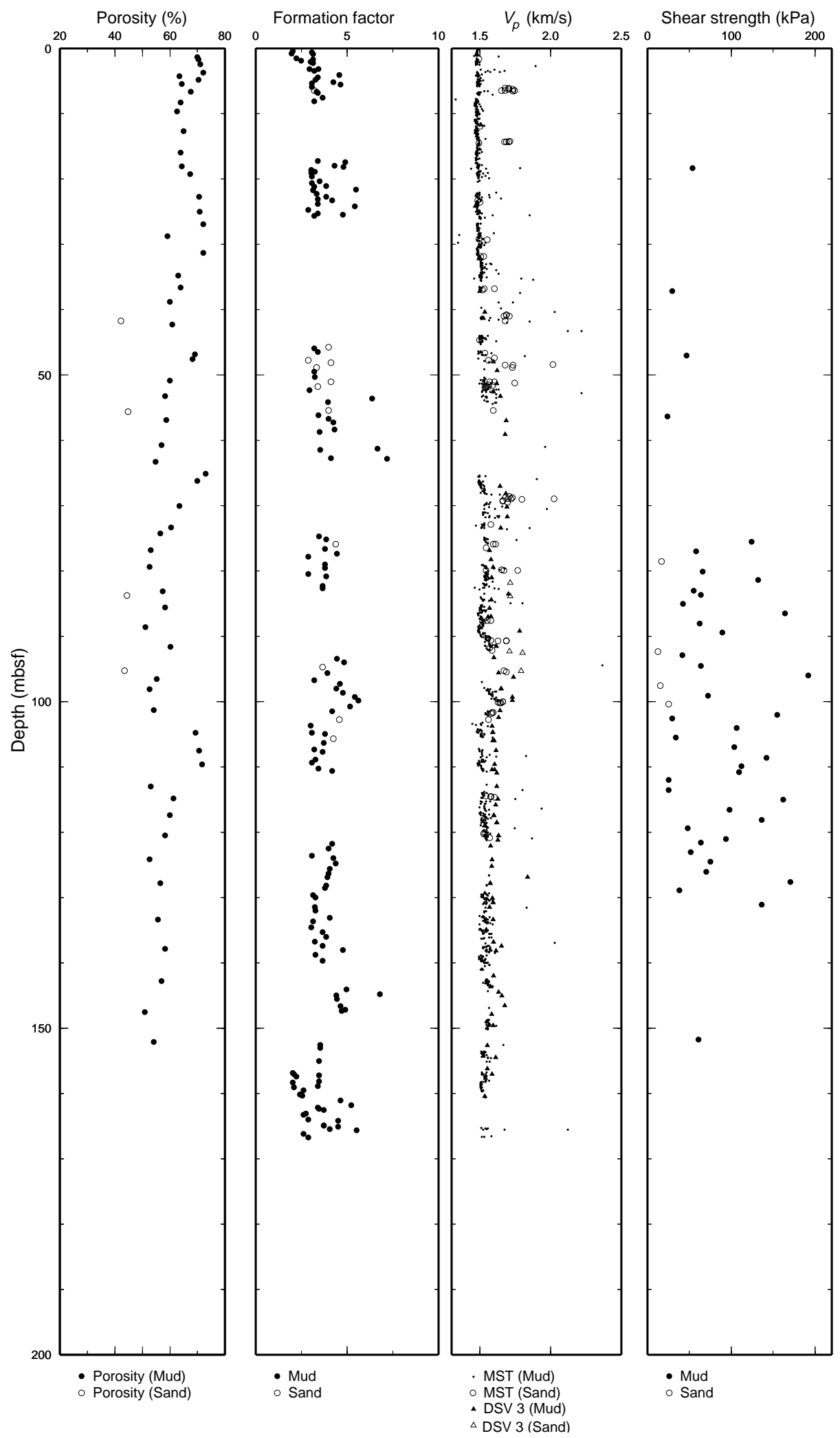

Figure 41 (continued). 

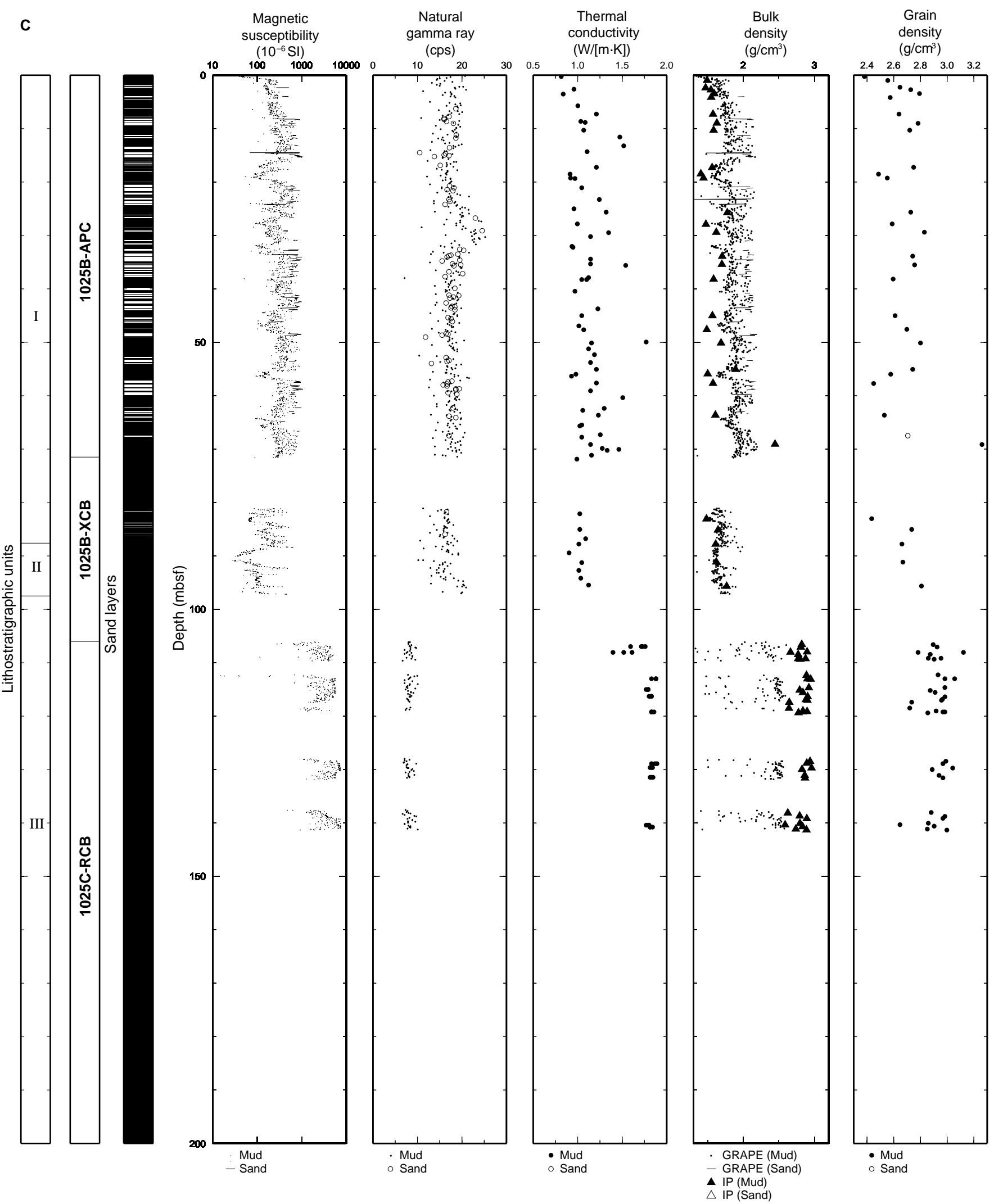

Figure 41 (continued). 


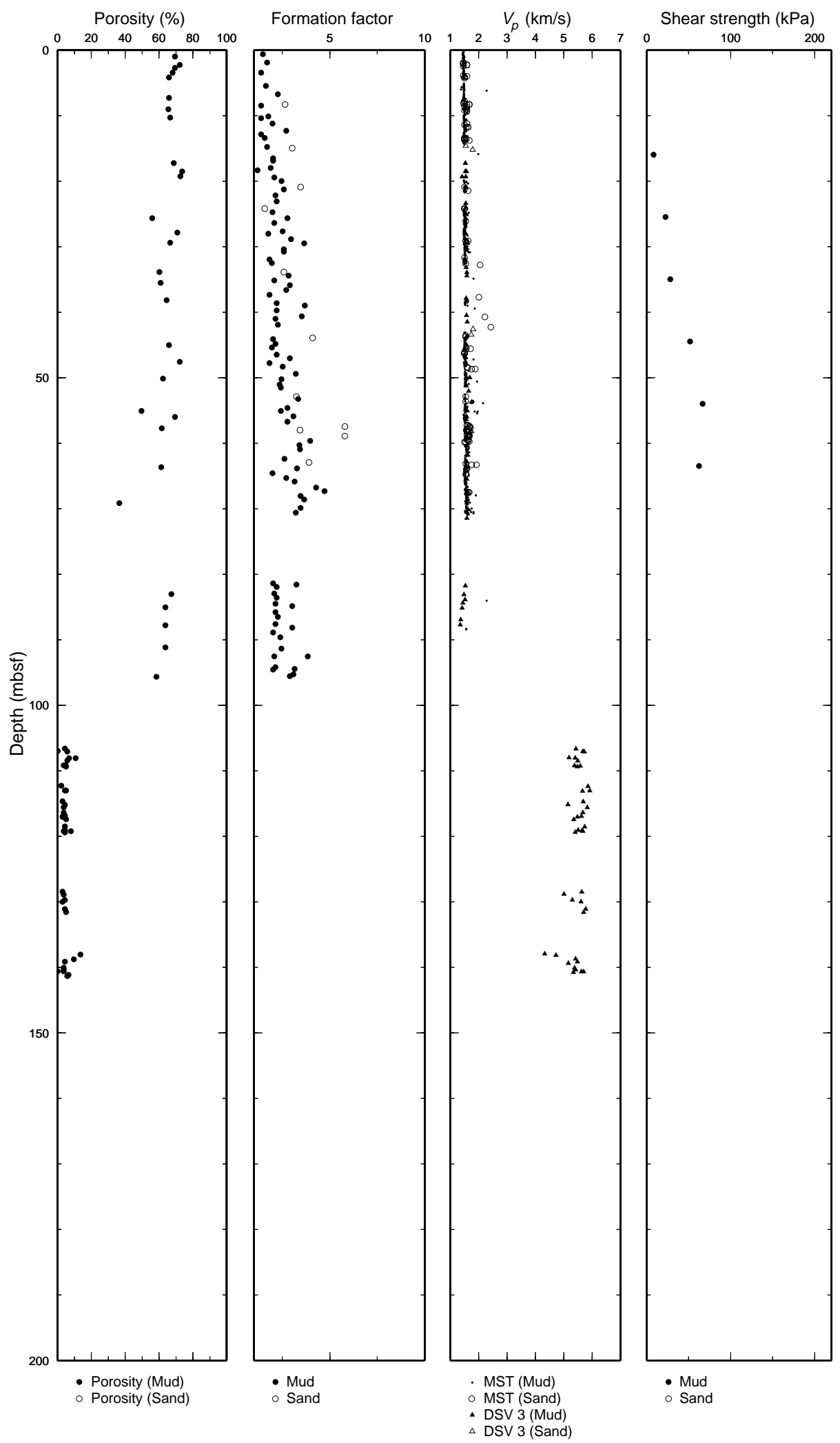

Figure 41 (continued). 
Table 19. Physical properties measurements for mud and sand from the upper 100 mbsf of Holes 1023A, 1024B, and $1025 \mathrm{~B}$.

\begin{tabular}{|c|c|c|c|c|c|c|c|}
\hline \multirow[b]{2}{*}{ Measurement type } & \multirow[b]{2}{*}{ Hole } & \multicolumn{3}{|c|}{ Mud } & \multicolumn{3}{|c|}{ Sand } \\
\hline & & Average & SD & $n$ & Average & SD & $n$ \\
\hline $\operatorname{MS}\left(10^{-6} \mathrm{SI}\right)$ & $\begin{array}{l}1023 \mathrm{~A} \\
1024 \mathrm{~B} \\
1025 \mathrm{~B}\end{array}$ & $\begin{array}{l}304 \\
243 \\
281\end{array}$ & $\begin{array}{l}143 \\
154 \\
160\end{array}$ & $\begin{array}{l}2559 \\
2676 \\
2386\end{array}$ & $\begin{array}{l}564 \\
650 \\
598\end{array}$ & $\begin{array}{l}210 \\
202 \\
206\end{array}$ & $\begin{array}{l}798 \\
499 \\
423\end{array}$ \\
\hline GRAPE $\left(\mathrm{g} / \mathrm{cm}^{3}\right)$ & $\begin{array}{l}1023 \mathrm{~A} \\
1024 \mathrm{~B} \\
1025 \mathrm{~B}\end{array}$ & $\begin{array}{l}1.85 \\
1.84 \\
1.80\end{array}$ & $\begin{array}{l}0.14 \\
0.14 \\
0.15\end{array}$ & $\begin{array}{l}1465 \\
1545 \\
2457\end{array}$ & $\begin{array}{l}2.02 \\
2.05 \\
2.00\end{array}$ & $\begin{array}{l}0.11 \\
0.10 \\
0.15\end{array}$ & $\begin{array}{l}466 \\
291 \\
256\end{array}$ \\
\hline IP density $\left(\mathrm{g} / \mathrm{cm}^{3}\right)$ & $\begin{array}{l}1023 \mathrm{~A} \\
1024 \mathrm{~B} \\
1025 \mathrm{~B}\end{array}$ & $\begin{array}{l}1.62 \\
1.61 \\
1.61\end{array}$ & $\begin{array}{l}0.11 \\
0.12 \\
0.20\end{array}$ & $\begin{array}{l}36 \\
44 \\
31\end{array}$ & $\begin{array}{l}1.88 \\
1.98 \\
-\end{array}$ & $\begin{array}{l}0.15 \\
0.03 \\
-\end{array}$ & $\begin{array}{r}6 \\
5 \\
-\end{array}$ \\
\hline IP grain density $\left(\mathrm{g} / \mathrm{cm}^{3}\right)$ & $\begin{array}{l}1023 \mathrm{~A} \\
1024 \mathrm{~B} \\
1025 \mathrm{~B}\end{array}$ & $\begin{array}{l}2.67 \\
2.64 \\
2.67\end{array}$ & $\begin{array}{l}0.15 \\
0.09 \\
0.16\end{array}$ & $\begin{array}{l}36 \\
42 \\
31\end{array}$ & $\begin{array}{l}2.71 \\
2.72 \\
2.71\end{array}$ & $\begin{array}{l}0.08 \\
0.05 \\
-\end{array}$ & $\begin{array}{l}6 \\
7 \\
1\end{array}$ \\
\hline IP porosity (\%) & $\begin{array}{l}1023 \mathrm{~A} \\
1024 \mathrm{~B} \\
1025 \mathrm{~B}\end{array}$ & $\begin{array}{l}61 \\
64 \\
65\end{array}$ & $\begin{array}{l}6 \\
7 \\
8\end{array}$ & $\begin{array}{l}36 \\
42 \\
31\end{array}$ & $\begin{array}{l}49 \\
49 \\
49\end{array}$ & $\begin{array}{r}7 \\
8 \\
11\end{array}$ & $\begin{array}{l}6 \\
6 \\
7\end{array}$ \\
\hline Therm. cond. $(\mathrm{W} /[\mathrm{m} \cdot \mathrm{K}])$ & $\begin{array}{l}1023 \mathrm{~A} \\
1024 \mathrm{~B} \\
1025 \mathrm{~B}\end{array}$ & $\begin{array}{l}1.10 \\
1.12 \\
1.12\end{array}$ & $\begin{array}{l}0.16 \\
0.16 \\
0.18\end{array}$ & $\begin{array}{l}83 \\
72 \\
68\end{array}$ & $\begin{array}{l}1.43 \\
1.44 \\
1.50\end{array}$ & $\begin{array}{l}0.36 \\
0.34 \\
0.28\end{array}$ & $\begin{array}{r}12 \\
12 \\
8\end{array}$ \\
\hline PWL $(\mathrm{km} / \mathrm{s})$ & $\begin{array}{l}1023 \mathrm{~A} \\
1024 \mathrm{~B} \\
1025 \mathrm{~B}\end{array}$ & $\begin{array}{l}1.53 \\
1.53 \\
1.53\end{array}$ & $\begin{array}{l}0.04 \\
0.04 \\
0.05\end{array}$ & $\begin{array}{r}871 \\
1352 \\
675\end{array}$ & $\begin{array}{l}1.60 \\
1.63 \\
1.60\end{array}$ & $\begin{array}{l}0.07 \\
0.08 \\
0.09\end{array}$ & $\begin{array}{r}221 \\
93 \\
97\end{array}$ \\
\hline $\operatorname{DSV}(\mathrm{km} / \mathrm{s})$ & $\begin{array}{l}1023 \mathrm{~A} \\
1024 \mathrm{~B} \\
1025 \mathrm{~B}\end{array}$ & $\begin{array}{l}1.55 \\
1.62 \\
1.56\end{array}$ & $\begin{array}{l}0.03 \\
0.07 \\
0.06\end{array}$ & $\begin{array}{r}5 \\
33 \\
57\end{array}$ & $\begin{array}{l}\overline{1.75} \\
1.70\end{array}$ & $\begin{array}{l}\overline{0} \\
0.05 \\
0.10\end{array}$ & $\begin{array}{r}- \\
5 \\
6\end{array}$ \\
\hline NGR (cps) & $\begin{array}{l}1023 \mathrm{~A} \\
1024 \mathrm{~B} \\
1025 \mathrm{~B}\end{array}$ & $\begin{array}{l}17.5 \\
17.0 \\
17.3\end{array}$ & $\begin{array}{l}2.3 \\
2.1 \\
2.4\end{array}$ & $\begin{array}{l}956 \\
892 \\
441\end{array}$ & $\begin{array}{l}18.1 \\
16.8 \\
17.3\end{array}$ & $\begin{array}{l}2.2 \\
1.9 \\
2.0\end{array}$ & $\begin{array}{r}185 \\
99 \\
75\end{array}$ \\
\hline $\mathrm{FF}$ & $\begin{array}{l}1023 \mathrm{~A} \\
1024 \mathrm{~B} \\
1025 \mathrm{~B}\end{array}$ & $\begin{array}{l}2.65 \\
3.75 \\
2.48\end{array}$ & $\begin{array}{l}0.45 \\
0.94 \\
0.70\end{array}$ & $\begin{array}{r}108 \\
83 \\
95\end{array}$ & $\begin{array}{l}3.55 \\
3.70 \\
3.59\end{array}$ & $\begin{array}{l}0.78 \\
0.48 \\
1.29\end{array}$ & $\begin{array}{l}55 \\
11 \\
11\end{array}$ \\
\hline
\end{tabular}

Notes: $\mathrm{SD}=$ standard deviation, and $n=$ number. $-=$ no samples or not calculated. Measurements are for magnetic susceptibility (MS), bulk density from GRAPE and index properties (IP) measurements, IP grain density and porosity, thermal conductivity (Therm. cond.), $P$-wave velocities from the MST (PWL) and DSV, natural gamma-ray activity (NGR), and formation factor (FF) from electrical resistivity.

Table 20. The number of measurements for identified sand samples relative to the total number of measurements in comparison with the total thickness of sand layers relative to the depth of drilled section.

\begin{tabular}{lccc}
\hline $\begin{array}{c}\text { Measurement } \\
\text { type }\end{array}$ & $\begin{array}{c}\text { Hole 1023A } \\
\text { (\% sand) }\end{array}$ & $\begin{array}{c}\text { Hole 1024B } \\
\text { (\% sand) }\end{array}$ & $\begin{array}{c}\text { Hole 1025B } \\
\text { (\% sand })\end{array}$ \\
\hline Sand (full hole) & 16.70 & 10.14 & 14.23 \\
GRAPE & 17.63 & 10.39 & 15.80 \\
MS & 17.32 & 10.32 & 15.06 \\
NGR & 16.21 & 10.30 & 14.53 \\
PWL & 20.23 & 6.43 & 12.56 \\
DSV & 7.79 & 5.68 & 9.52 \\
IP & 9.88 & 7.81 & 3.13 \\
TC & 15.34 & 10.53 & 10.53 \\
FF & 33.74 & 11.70 & 10.38 \\
\hline
\end{tabular}

Note: Measurements: GRAPE = gamma-ray attenuation porosity evaluator; MS = magnetic susceptibility; NGR $=$ natural gamma-ray activity; PWL $=P$-wave logger; $\mathrm{DSV}=$ digital sonic velocimeter; IP = index properties; $\mathrm{TC}=$ thermal conductivity; and $\mathrm{FF}=$ formation factor.

\section{Formation Factor}

Formation factor calculated from electrical resistance measurements in sediment increases from about 2 to 4 with depth at Sites 1023 and 1024 and from 1.5 to 3 at Site 1025 . Sand layers generally have higher values than do mud layers, so each of the two sediment types was fit separately with either a power or exponential function (Table 22 on CD-ROM, back pocket). A weighted value for this function was then calculated from the proportions of mud vs. sand given in Table 20. The resulting functions are FF $=2.3082 \mathrm{e}^{0.0035 \mathrm{~d}}$ for Hole
$1023 \mathrm{~A}, \mathrm{FF}=3.1303 \mathrm{~d}^{0.0371}$ for Holes $1024 \mathrm{~A}$ and $1024 \mathrm{~B}$, and $\mathrm{FF}=$ $1.2555 \mathrm{~d}^{0.1961}$ for Holes $1025 \mathrm{~A}$ and $1025 \mathrm{~B}$, where $\mathrm{d}$ is depth in mbsf.

\section{Basalt Properties}

The basalt cores recovered from Hole $1025 \mathrm{C}$ were measured continuously with the MST, and discrete samples were taken for IP, DSV, and thermal conductivity measurements. Figure 47 summarizes the results for porosity, $P$-wave velocity and thermal conductivity in context with the results from Hole 1025B sediments. For samples with larger vesicles ( $1 \mathrm{~mm}$ to $>10 \mathrm{~mm}$ diameter), the measured porosities represent the lower limit of actual values because the pore saturant (seawater) does not stay in these vesicles during the measurements of wet volume and wet weight; it simply flows out of the vesicles that are close to the surface. This is also true for DSV measurements. Thermal conductivity determinations are carried out with the sample completely immersed in water. Samples with extremely large vesicles (Sections 168-1025C-1R-1, 1R-2, and 5R-1) show qualitatively the expected behavior, with high porosity, low velocity, and low thermal conductivity, but measured values should be used with caution.

\section{THERMAL STUDIES}

In situ temperatures were measured at 15 depths in Hole 1023A, eight depths in Hole 1024B, and six depths in Hole 1025B. All APC tool and DVTP deployments successfully returned data, but some data records indicate that tool motion caused frictional heating during 


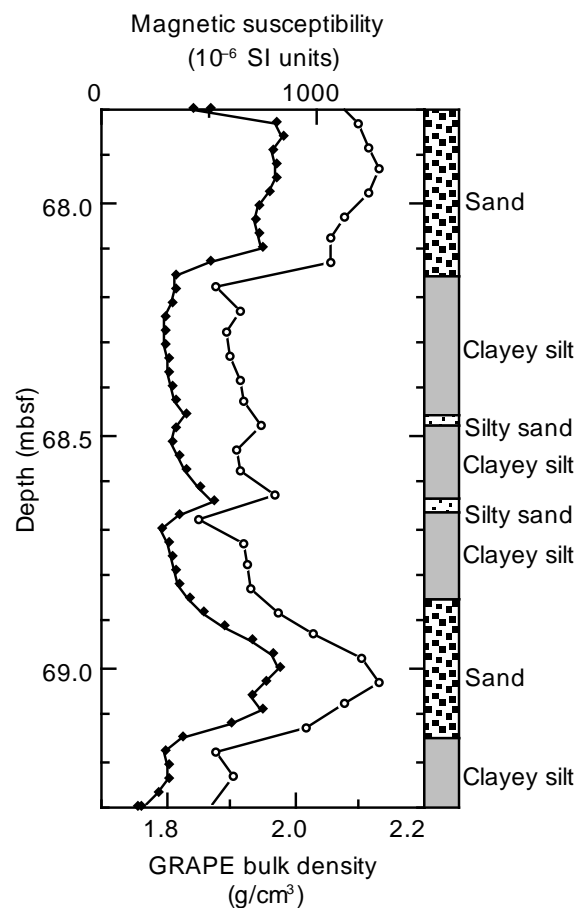

Figure 42. Magnetic susceptibility (solid circles) and GRAPE bulk density (open circles) from Section 168-1023A-8H-2. From the VCD descriptions: sand/sandstone; silty sand/sandy silt; silty clay/clayey silt. Sand/sandstone and silty clay/clayey silt are the most common examples for sand and mud, respectively, clearly identifiable with magnetic susceptibility and GRAPE data before the cores were split.

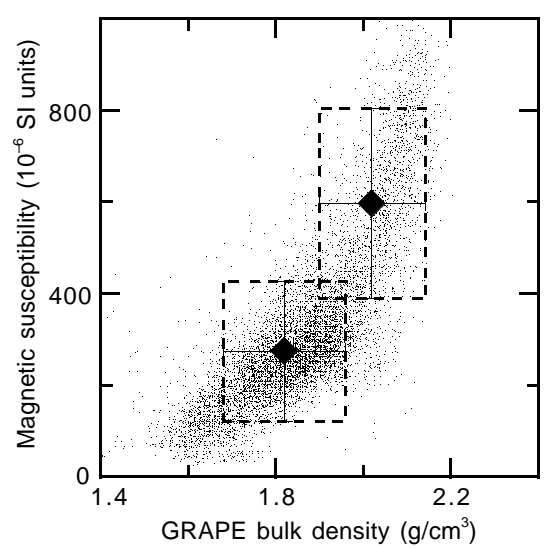

Figure 43. Bulk density vs. magnetic susceptibility from MST measurements. The data are for cores from Holes 1023A, 1024B, and 1025B.

the thermal equilibration period. Results of deployments in all three holes are listed in Table 23 and illustrated in Figures 48 through 50.

The use of idealized thermal models to simulate tool response and the methods used for matching observations to the models to extrapolate equilibrium temperatures are discussed in the "Downhole Tools" section of the "Methods" chapter (this volume) and in Davis et al. (in press). These extrapolations are sensitive to the assumed thermal conductivity of the sediments, particularly for APC tool measurements. Thermal conductivity values based on measurements of core samples immediately adjacent to temperature-tool measurement

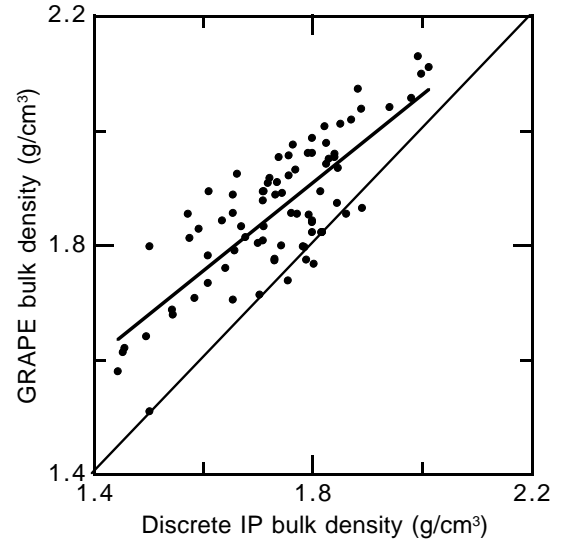

Figure 44. Index properties bulk density vs. GRAPE bulk density for core from Hole 1023A. A linear fit is applied to the data, illustrating a greater offset with lower bulk densities. This offset would likely be far less if a correction was made to the data as suggested by Boyce (1976).

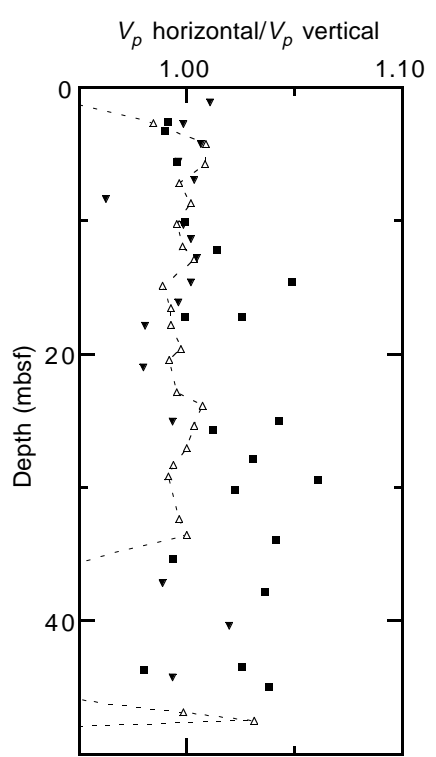

Figure 45. Anisotropy defined as the ratio of horizontal $P$-wave velocity $\left(V_{p}\right.$ horizontal, DSVs 2 and 3) to vertical $P$-wave velocity $\left(V_{p}\right.$ vertical, DSV 1$)$ for Holes 1023A, 1024B, and 1025B in the upper $50 \mathrm{mbsf}$. There are no anisotropy data available from greater depths. Open upward-pointing triangle $=$ Hole 1023A; solid downward-pointing triangle $=$ Hole 1024B; and square $=$ Hole $1025 \mathrm{~B}$.

locations often yielded extrapolated temperatures that were inconsistent with values above and below, particularly with the APC tool. Thermal conductivity values determined from measurements of sediments recovered in the core catcher when the APC tool was run were found to produce extrapolated temperatures that were no more consistent. For this reason, results based on a range of reasonable thermal conductivities $(1.0-1.5 \mathrm{~W} /[\mathrm{m} \cdot \mathrm{K}])$ were calculated (Table 23$)$. Extrapolated temperatures based on an intermediate sediment thermal conductivity of $1.1 \mathrm{~W} /(\mathrm{m} \cdot \mathrm{K}$ ) (Figs. 48-50) were used for calculation of thermal gradients and heat flow (Fig. 51; Table 24). The symbols 


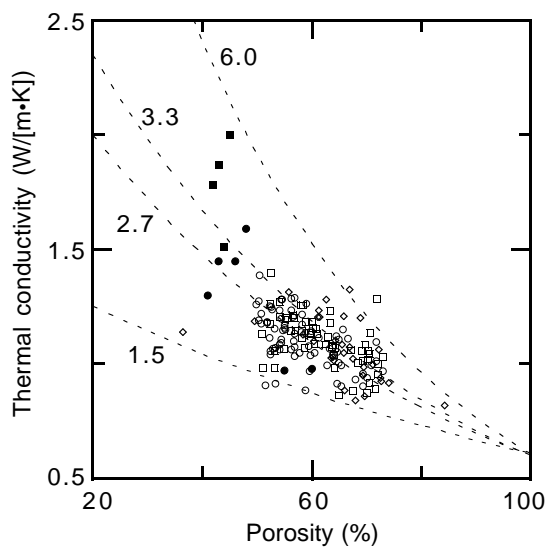

Figure 46. Porosity vs. thermal conductivity for mud (open symbols) and sand (solid symbols). The data are for Holes 1023A (circles), 1024B (squares), and 1025B (diamonds). The lines indicate theoretical values based on the geometric mean mixing model. The curve parameter is the matrix thermal conductivity in $\mathrm{W} /(\mathrm{m} \cdot \mathrm{K})$. Matrix thermal conductivities of 1.5 and 6.0 $\mathrm{W} /(\mathrm{m} \cdot \mathrm{K})$ represent the upper and lower limit; best fits for Holes $1023 \mathrm{~A}$, $1024 \mathrm{~B}$, and $1025 \mathrm{~B}$ are $2.7,3.1$, and $3.3 \mathrm{~W} /(\mathrm{m} \cdot \mathrm{K})$, respectively.

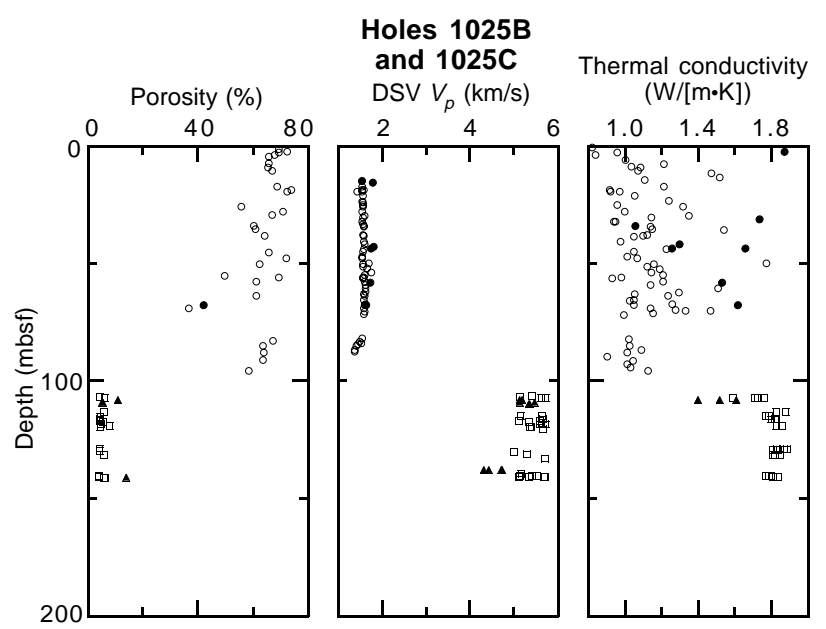

Figure 47. Summary of porosity, $P$-wave velocity, and thermal conductivity data for sediments from Hole 1025B (open circles = mud; solid circles = sand) and for basalt from Hole $1025 \mathrm{C}$ (open squares = massive basalts; solid triangles $=$ vesicular basalts).

used to indicate estimated temperatures in Figure 51 generally span the range of likely temperatures estimated using various thermal conductivities, as listed in Table 24.

Figure 51 illustrates thermal gradients for the three Hydrothermal Transition sites, based on these equilibrium temperatures, as well as a calculated thermal conductivity vs. depth profile for each hole and Bullard plots showing heat flow. Results of these calculations are also summarized in Table 24. The thermal conductivity structure for each hole was calculated as the weighted harmonic mean of measured values (see "Physical Properties" section, this chapter) within the depth intervals of the temperature measurements. Apparent thermal conductivities are greatest $(1.1-1.2 \mathrm{~W} /[\mathrm{m} \cdot \mathrm{K}])$ where sand layers are most common.

DVTP data seem to provide the most consistent thermal gradients and heat-flow determinations. APC tool data may be less consistent along the Hydrothermal Transition Transect because (1) the APC tool is deployed routinely in shallower, softer sediment, where tool motion is more likely, (2) abrupt variations in sediment thermal conductivity are common in shallow sediments, (3) the theoretical conduction model used to simulate the thermal response of the APC tool is less realistic than that used for the DVTP (1-D radial vs. 2-D radial), and/or (4) the greater thermal mass of the APC tool in the vicinity of the temperature sensor requires a longer equilibration time, so the extrapolations are less well constrained. In any case, the heat-flow values determined for the Hydrothermal Transition sites during Leg 168 are consistent with earlier seafloor measurements (Davis et al., this volume; Fig. 52) and suggest that thermal transport through the sediment column at these sites is entirely conductive.

One of the objectives of determining the thermal structure of the sediment section along the Hydrothermal Transition transect was to obtain accurate determinations of temperatures at the sediment/ basement interface. This interface has been inferred to represent a hydrologic boundary between the sediment section (where heat is transferred conductively) and igneous basement (where highly permeable basalt is thought to host convective heat transport). Temperatures at the sediment/basement interface were estimated by extrapolation of the Bullard plots to the top of basement (as defined by the driller; Fig. 51; Table 24; see "Igneous Petrology" in the "Basement Lithology, Petrology, Geochemistry, and Alteration" section, this chapter) and reveal a systematic increase in temperature with increasing age and distance from the ridge crest.

The thermal data presented in this section provide no constraints on the actual location or sharpness of the hydrologic boundary; based on other data collected during this leg, conductive conditions may persist through massive units some distance into the upper igneous crust. This ambiguity must be kept in mind when using these temperatures for those of convecting basement fluids. Additional insight may be provided by results of the CORK experiments at Sites 1024 and 1025 .

\section{PACKER EXPERIMENTS}

The drill-string packer was deployed in both Holes $1024 \mathrm{C}$ and $1025 \mathrm{C}$ to determine permeability and estimate in situ pressures of the uppermost basement at these sites. Unfortunately, the packer did not inflate properly when deployed in Hole $1025 \mathrm{C}$, although it had worked flawlessly earlier in the leg in both Holes 1026B and 1027C. We determined the failure in Hole $1025 \mathrm{C}$ to have resulted from faulty action of the packer control tube, which had been replaced during routine maintenance immediately before this packer deployment. The new control tube did not fully extend as required for proper packer inflation, but this could not be determined until the packer was tripped back to the surface and tested, by which time a CORK was being deployed in the hole. Weight was added to the BHA below the packer before the deployment in Hole $1024 \mathrm{C}$ to ensure full extension, and the packer worked properly in that hole.

Hole conditions were very poor in the basement section of Hole $1024 \mathrm{C}$, so the packer could be inflated only in casing. Only $10 \mathrm{~m}$ of open hole was cored in basement beneath the casing shoe at 165.7 mbsf (or $14 \mathrm{~m}$ into basement), and the deepest $5 \mathrm{~m}$ had filled in by the time of the packer measurements. Thus, any interpretation of the results must account for ambiguity in the length of the tested section because of fill in half the original open-hole section, as well as uncertainty about the hydraulic quality of the cement behind the casing.

Figure 53 shows the pressure record collected by the downhole gauge during the experiments conducted with the packer inflated in casing at $148.7 \mathrm{mbsf}, 17 \mathrm{~m}$ above the casing shoe. Two slug tests were attempted, but pressures decayed very quickly. Two injection tests were then conducted. Because there was so little open hole and only $151.7 \mathrm{~m}$ of sediment overburden, special care was taken to keep 
Table 23. Extrapolated equilibrium temperatures from APC tool and DVTP deployments along the Hydrothermal Transition Transect.

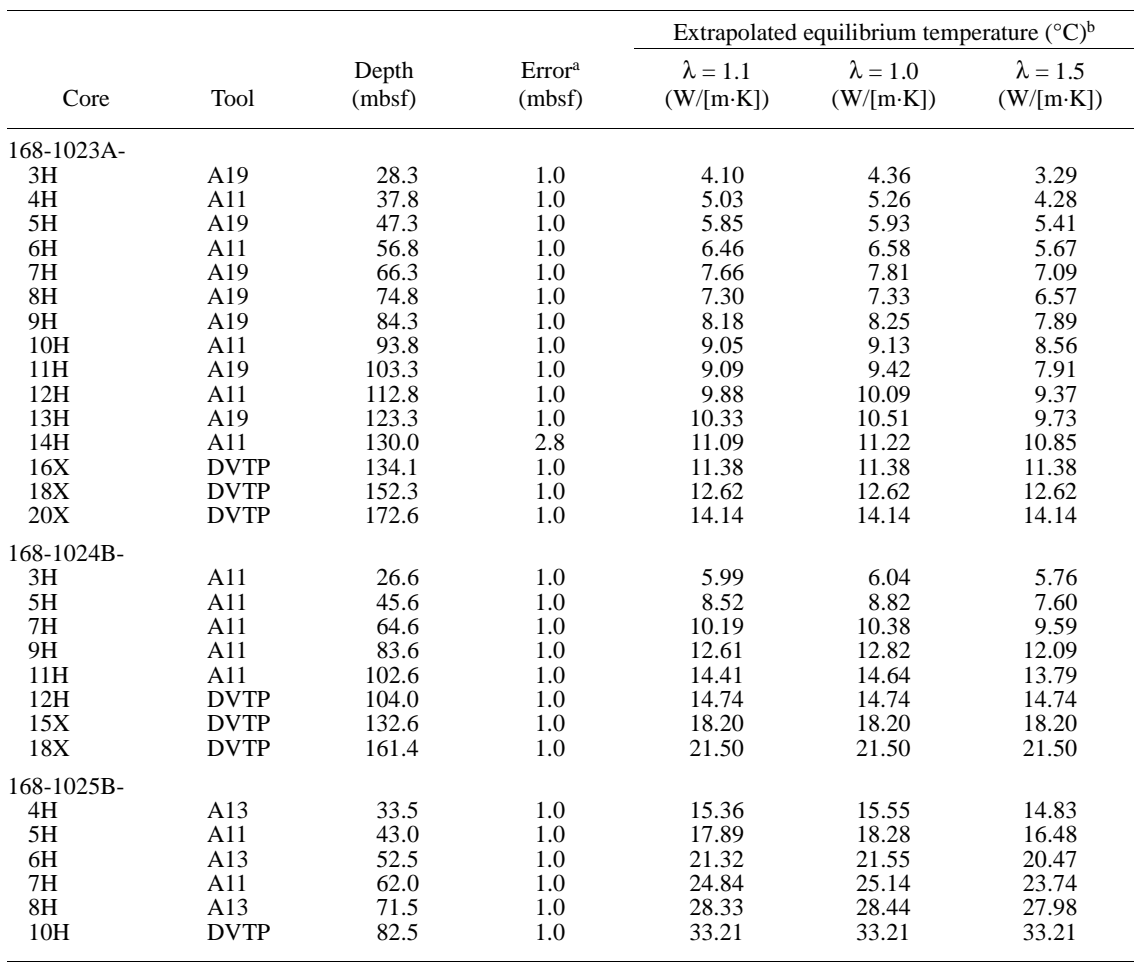

Note: Tools: A11 = APC tool 11; A13 = APC tool 13; A19 = APC tool 19; and DVTP = Davis/Villinger Temperature Probe.

${ }^{a}$ Depth error assumed to be no less than the uncertainty of individual depths because of pipe stretch and tides (1.0 m) or as much as the difference between core length and recovery for APC cores that failed to "stroke out" completely during deployment.

${ }^{\mathrm{b}} \mathrm{A}$ range of equilibrium temperatures is shown based on the assumed thermal conductivity of the sediments surrounding the probe tip. The range in final temperatures illustrates the minimum uncertainty in final temperatures. See text for discussion. The extrapolated temperatures determined using a sediment thermal conductivity of $1.1 \mathrm{~W} /(\mathrm{m} \cdot \mathrm{K}) \mathrm{were}$ used in Figures 48 through 52 .

test pressures low to avoid damaging the hydraulic integrity of the cement and the sediment/casing seal and thus compromising the CORK experiment. The results of these tests require post-cruise processing to determine transmissivity and permeability, but the rapid decays of the slug tests and low pressures reached during injection tests qualitatively indicate a high transmissivity in the isolated zone. Because the isolated zone is so short, a very high permeability is indicated.

Similar decays could be produced if there were a hydraulic leak past the packer or around the casing. However, one feature of the pressure record argues against these possibilities: the offset in baseline pressures observed when the packer was inflated and deflated at 52 and $211 \mathrm{~min}$, respectively (Fig. 53). This offset indicates that both the packer and casing were properly sealed during the experiments. The sense of the offset-pressures in the sealed hole less than cold hydrostatic pressures in the open borehole-is consistent with cooling of the formation in the vicinity of the hole by the circulation of drilling fluids. This is supported by the temperatures-recorded by an internal sensor in the pressure gauge-which are very near bottom-water value. Similar but larger offsets were observed during the packer experiments in Holes $1026 \mathrm{~B}$ and $1027 \mathrm{C}$, and the magnitudes of these offsets remained constant during those packer experiments (see "Packer Experiments" section, "Rough Basement Transect" chapter, this volume). However, the magnitude of the offset in Hole 1024C clearly decays during the short period of the packer experiment, suggesting rebound of formation pressures during recovery from the thermal disturbance caused by drilling.

Although the packer malfunctioned in Hole $1025 \mathrm{C}$, the pressure record from the inflation attempt in casing is shown in Figure 54 because it suggests an offset between cold hydrostatic pressure and formation pressure. Testing of the packer after it was recovered indicat- ed that it would inflate partially at very low pressure but would then leak when pressure increased toward the desired inflation pressure. Although very noisy, the pressure record clearly suggests two pressure levels during the attempts to inflate the packer. These are interpreted as a cold hydrostatic borehole pressure level greater than 27.2 MPa when the go-devil first landed in the packer and a lower pressure level in the partially sealed hole when fluids were pumped in unsuccessful attempts to inflate the packer. The difference in these levels is about $80-100 \mathrm{kPa}$, a larger and apparently steadier pressure than that measured in Hole 1024C. The magnitude of this difference is greater than that associated with the density difference between cold drilling fluid and warmer formation fluids, suggesting either a greater influence of cold drilling water invading basement below the bottom of the hole or a true underpressure of uppermost basement fluids at Site 1025. The former is more likely, as water was observed to be discharging form the reentry cone at the time of casing operations.

\section{CORK EXPERIMENTS}

CORK installations were successfully deployed in both Holes $1024 \mathrm{C}$ and $1025 \mathrm{C}$ to seal the holes and allow long-term monitoring of in situ temperatures and pressures, particularly in uppermost basement. As described by Davis et al. (1992), each CORK consists of a seal in the reentry cone, a long-term data logger, a pressure sensor inside the seal as well as a reference pressure gauge outside the seal, and a cable with 10 thermistors. In addition, each CORK experiment included an "OsmoSampler" ("Methods" chapter, this volume) carried on the bottom of the thermistor cable. The configurations of the sensor strings deployed in Holes 1024C and 1025C are shown in Fig- 

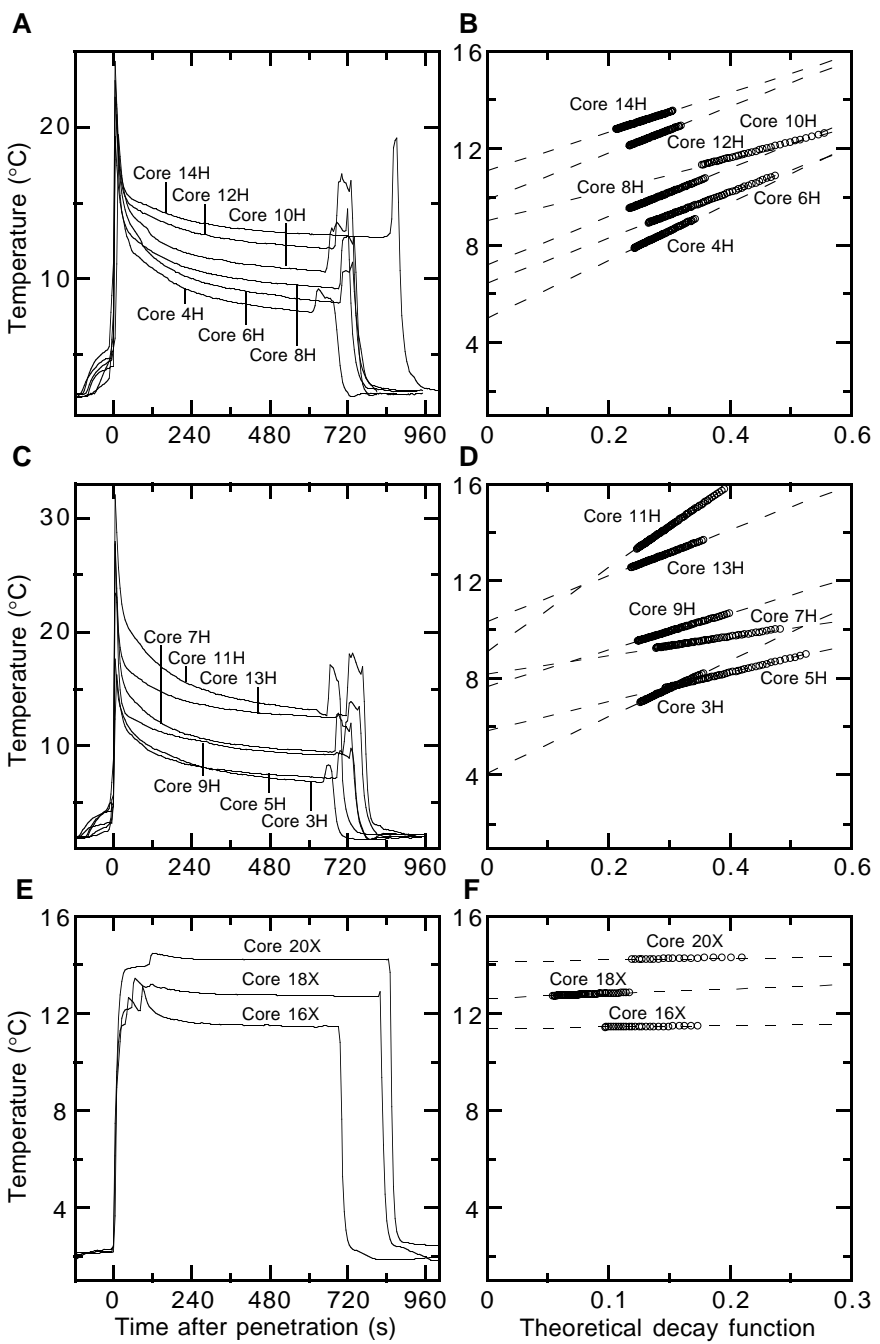

Figure 48. Temperature vs. time and temperature vs. theoretical decay functions for all tool deployments in Hole 1023A. A. Temperature vs. time following tool penetration for APC tool 11. B. Temperature vs. the APC tool theoretical decay function for APC tool 11, showing selected observations (circles) and extrapolated final temperatures (intersection of dashed lines with ordinate). C. Temperature vs. time following tool penetration for APC tool 19. D. Temperature vs. the APC tool theoretical decay function for APC tool 19, showing selected observations (circles) and extrapolated final temperatures (intersection of dashed lines with ordinate). E. Temperature vs. time following tool penetration of the DVTP. F. Temperature vs. the DVTP theoretical decay function, showing selected observations (circles) and extrapolated final temperatures (intersection of dashed lines with ordinate).

ure 55, and relevant data are summarized in Table 25. In each hole, the CORK was installed 1-2 days after final basement coring, immediately following a pipe trip for packer experiments ("Packer Experiments" section, this chapter). Sinker bars were run shortly before the CORK deployments to determine the depth of fill in the open-hole sections, and the thermistor cables were terminated to conform as closely as possible to hole depths. No data were available from the CORK experiments during Leg 168; the first data recovery is planned for summer of 1997 using the ROV Jason.

\section{REFERENCES}

Andrews, A.J., 1977. Low-temperature fluid alteration of oceanic layer 2 basalts, DSDP Leg 37. Can. J. Earth Sci., 14:911-926.

Baker, P.A., Stout, P.M., Kastner, M., and Elderfield, H., 1991. Large-scale lateral advection of seawater through oceanic crust in the central equatorial Pacific. Earth Planet. Sci. Lett., 105:522-533.

Boyce, R.E., 1976. Definitions and laboratory techniques of compressional sound velocity parameters and wet-water content, wet-bulk density, and porosity parameters by gravimetric and gamma-ray attenuation techniques. In Schlanger, S.O., Jackson, E.D., et al., Init. Repts. DSDP, 33: Washington (U.S. Govt. Printing Office), 931-958.

Claypool, G.E., and Kaplan, I.R., 1974. The origin and distribution of methane in marine sediments. In Kaplan, I.R. (Ed.), Natural Gases in Marine Sediments: New York (Plenum), 99-139.

Davis, E.E., Becker, K., Pettigrew, T., Carson, B., and MacDonald, R., 1992. CORK: a hydrologic seal and downhole observatory for deep-ocean boreholes. In Davis, E.E., Mottl, M.J., Fisher, A.T., et al., Proc. ODP, Init. Repts., 139: College Station, TX (Ocean Drilling Program), 43-53.

Davis, E.E., Mottl, M.J., Fisher, A.T., et al., 1992. Proc. ODP, Init. Repts., 139: College Station, TX (Ocean Drilling Program).

Davis, E.E., Villinger, H., MacDonald, R.D., Meldrum, R.D., and Grigel, J., in press. A rapid-response probe for bottom-hole temperature measurements in deep-ocean boreholes. Mar. Geophys. Res.

Emerson, S., and Hedges, J.I., 1988. Processes controlling the organic carbon content of open ocean sediments. Paleoceanography, 3:621-634.

Hekinian, R., and Morel, J.M., 1980. Basement rocks from the East Pacific Rise near $9^{\circ} \mathrm{N}$ compared with other ocean-floor volcanic provinces. In Rosendahl, B.R., Hekinian, R., et al., Init. Repts. DSDP, 54: Washington (U.S. Govt. Printing Office), 819-832.

Honnorez, J., Laverne, C., Hubberten, H.-W., Emmermann, R., and Muehlenbachs, K., 1983. Alteration processes in Layer 2 basalts from Deep Sea Drilling Project Hole 504B, Costa Rica Rift. In Cann, J.R., Langseth, M.G., Honnorez, J., Von Herzen, R.P., White, S.M., et al., Init. Repts. DSDP, 69: Washington (U.S. Govt. Printing Office), 509-546.

Hoppie, B.W., Blum, P., and the Shipboard Scientific Party, 1994. Natural gamma-ray measurements on ODP cores: introduction to procedures with examples from Leg 150. In Mountain, G.S., Miller, K.G., Blum, P., et al., Proc. ODP, Init. Repts., 150: College Station, TX (Ocean Drilling Program), 51-59.

Laverne, C., Belarouchi, A., and Honnorez, J., 1996. Alteration mineralogy and chemistry of the upper oceanic crust from Hole 896A, Costa Rica Rift. In Alt, J.C., Kinoshita, H., Stokking, L.B., and Michael, P.J. (Eds.), Proc. ODP, Sci. Results, 148: College Station, TX (Ocean Drilling Program), 151-170.

Natland, J.H., 1980. Effect of axial magma chambers beneath spreading centers on the compositions of basaltic rocks. In Rosendahl, B.R., Hekinian, R., et al., Init. Repts. DSDP, 54: Washington (U.S. Govt. Printing Office), $833-850$.

Sager, W.W., and Hall, S.A., 1990. Magnetic properties of black mud turbidites from ODP Leg 116, Distal Bengal Fan, Indian Ocean. In Cochran, J.R., Stow, D.A.V., et al., Proc. ODP, Sci. Results, 116: College Station, TX (Ocean Drilling Program), 317-336.

Teagle, D.A.H., Alt, J.C., Bach, W., Halliday, A.N., and Erzinger, J., 1996. Alteration of upper ocean crust in a ridge-flank hydrothermal upflow zone: mineral, chemical, and isotopic constraints from Hole 896A. In Alt, J.C., Kinoshita, H., Stokking, L.B., and Michael, P.J. (Eds.), Proc. ODP, Sci. Results, 148: College Station, TX (Ocean Drilling Program), 119150.

Wheat, C.G., Feely, R.A., and Mottl, M.J., 1996. Phosphate removal by oceanic hydrothermal processes: an update of the phosphate budget in the oceans. Geochim. Cosmochim. Acta, 60:3593-3608.

Wheat, C.G., and Mottl, M.J., 1994. Hydrothermal circulation, Juan de Fuca Ridge eastern flank: factors controlling basement water composition. $J$. Geophys. Res., 99:3067-3080.

Ms 168IR-104

\section{NOTE: For all sites drilled, core-description forms ("barrel sheets") and core photo- graphs can be found in Section 3, beginning on page 213. Smear-slide data and thin- section data can be found on CD-ROM. See Table of Contents for material contained on CD-ROM.}


A

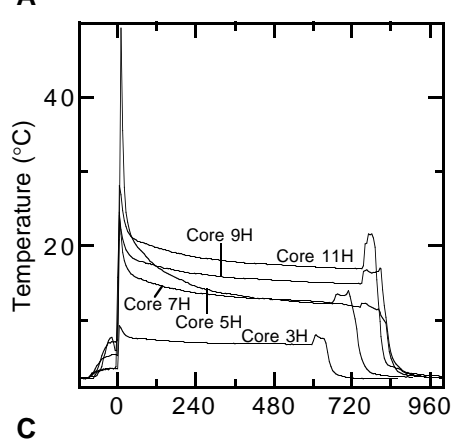

B
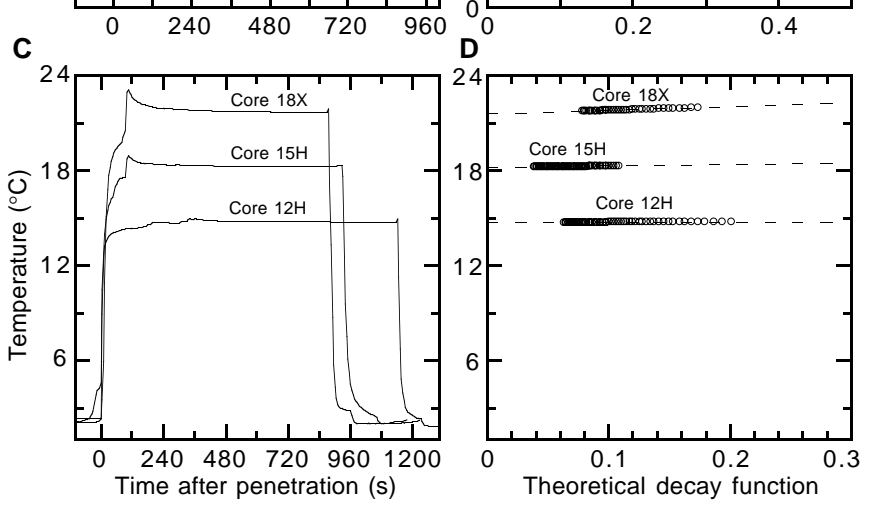

Figure 49. Temperature vs. time and temperature vs. theoretical decay functions for all tool deployments in Hole 1024B. Symbols as in Fig. 48. A. Temperature vs. time following tool penetration for APC tool 11. B. Temperature vs. the APC tool theoretical decay function for APC tool 11. C. Temperature vs. time following tool penetration for the DVTP. D. Temperature vs. the DVTP theoretical decay function.

A
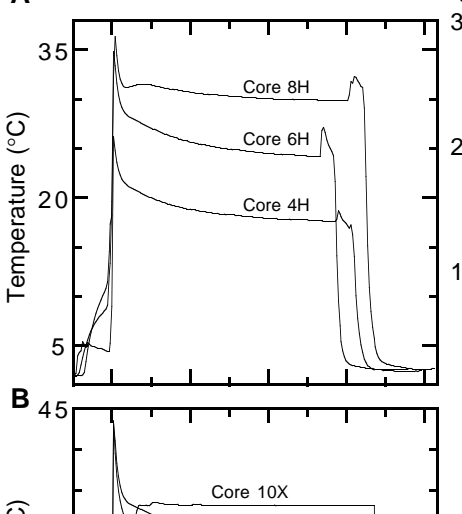

C

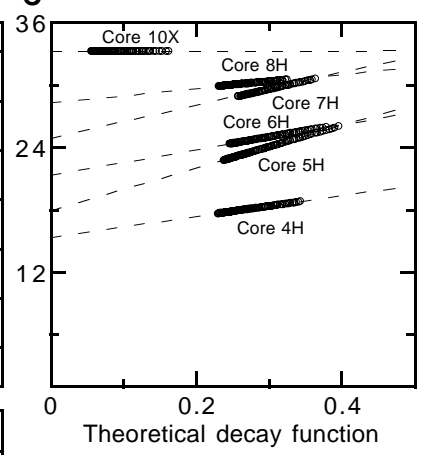

A

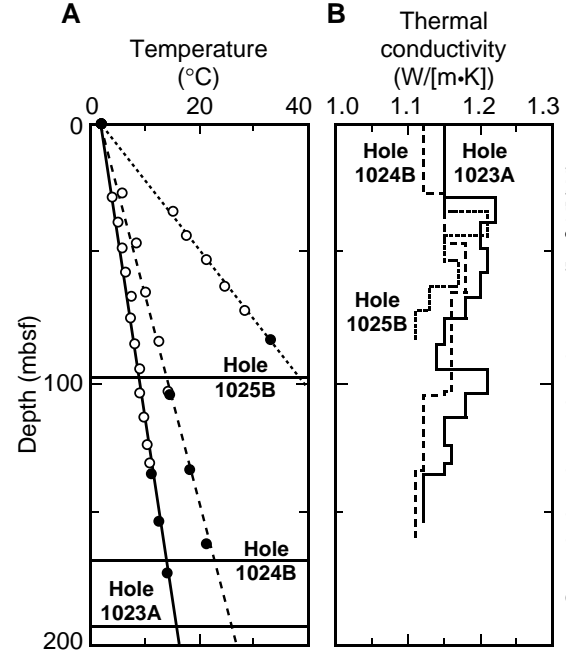

C

Temperature $\left({ }^{\circ} \mathrm{C}\right)$

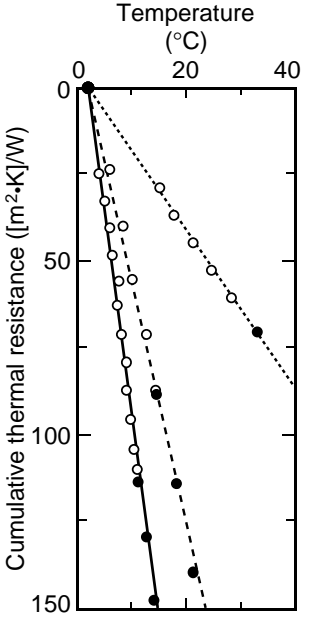

Figure 51. A. Equilibrium temperatures vs. depth along the Hydrothermal Transition Transect. Open circles $=$ APC tool data; filled circles $=$ DVTP data. The range in estimated temperatures shown in Table 23 (based on different assumed thermal conductivities) is generally smaller than the symbols used to represent final temperature values. Subvertical lines are least-squares best fits of all data, forced to pass through a bottom-water temperature of $1.85^{\circ} \mathrm{C}$ at the seafloor. Horizontal lines indicate depths of basement at each site, as labeled. B. Calculated thermal conductivity vs. depth profiles, based on a lithology-weighted harmonic mean of measured values within depth intervals of temperature measurements. C. Bullard plot showing heat flow for the Hydrothermal Transition drill sites, with symbols as in A. Lines are the least-squares best fits of all data, forced to pass through a bottom-water temperature of $1.85^{\circ} \mathrm{C}$ at the seafloor.

Table 24. Depth to basement, thermal gradient, heat flow, and extrapolated temperature at the top of basement for Hydrothermal Transition sites.

\begin{tabular}{ccccc}
\hline Hole & $\begin{array}{c}\text { Depth to } \\
\text { basement } \\
(\mathrm{m})\end{array}$ & $\begin{array}{c}\text { Thermal } \\
\text { gradient }^{\mathrm{b}} \\
\left({ }^{\circ} \mathrm{C} / \mathrm{m}\right)\end{array}$ & $\begin{array}{c}\text { Heat flow }^{\mathrm{b}} \\
\left(\mathrm{mW} / \mathrm{m}^{2}\right)\end{array}$ & $\begin{array}{c}\text { Basement } \\
\text { temperature }^{\mathrm{c}} \\
\left({ }^{\circ} \mathrm{C}\right)\end{array}$ \\
\hline 1023A & 192.8 & 0.071 & 84 & 15.5 \\
1024B & 167.8 & 0.125 & 146 & 22.8 \\
1025B & 97.5 & 0.375 & 443 & 38.6 \\
\hline
\end{tabular}

aSee "Lithostratigraphy" section (this chapter) for explanation of how depths to basement were calculated.

${ }^{\mathrm{b}}$ Based on least-squares best fit of all equilibrium temperature data forced to pass through bottom water of $1.85^{\circ} \mathrm{C}$ at the seafloor.

${ }^{c}$ Extrapolation of thermal gradient to top of basement.

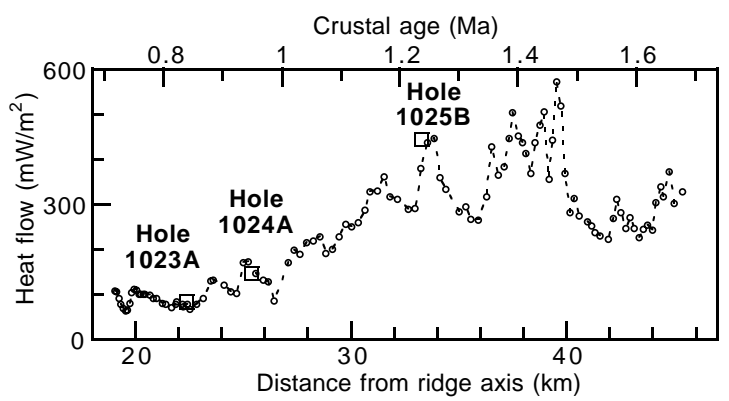

Temperature vs. time and temperature vs. theoretical decay functions for all tool deployments in Hole 1025B. Symbols as in Fig. 48. A. Temperature vs. time following tool penetration for APC tool 13. B. Temperature vs. time following tool penetration for APC tool 11 and the DVTP. C. Temperature vs. the theoretical decay functions for APC tools 11 and 13 and the DVTP. 


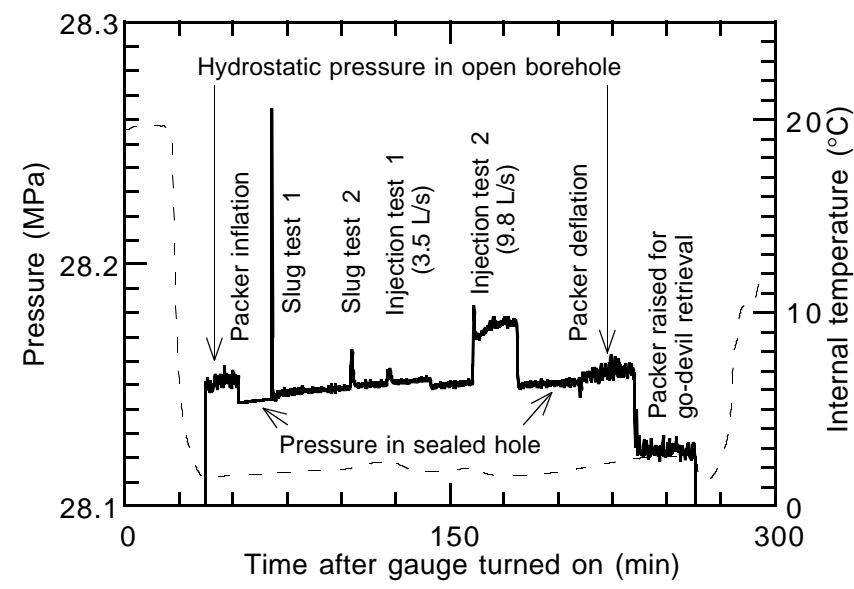

Figure 53. Pressures and internal temperatures recorded with a downhole electronic pressure gauge during the packer experiments in Hole 1024C, conducted with the packer in casing at 148.7 mbsf.

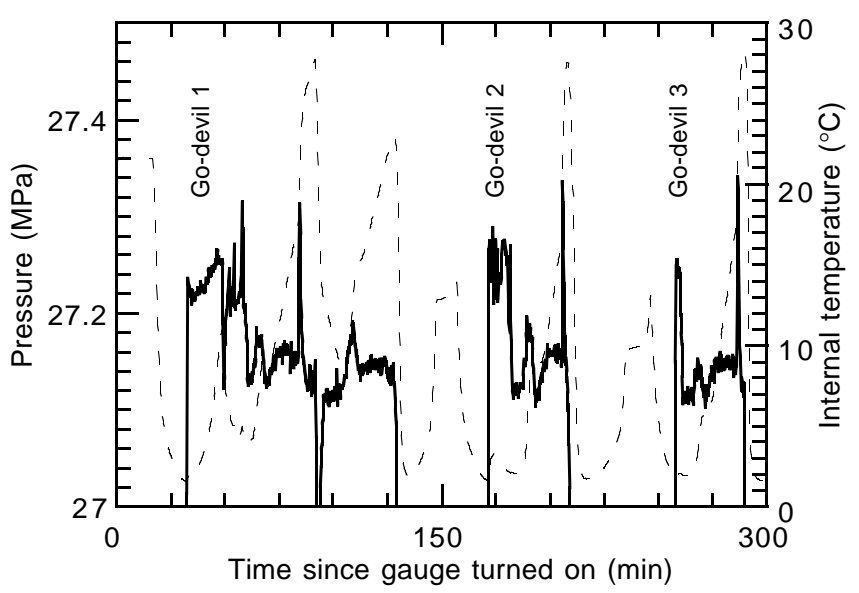

Figure 54. Pressures and internal temperatures recorded with a downhole electronic gauge during the attempted packer inflations in casing in Hole 1025C. Note that there were three deployments of the go-devil before the problem was judged to lie with the packer and the experiments were terminated.

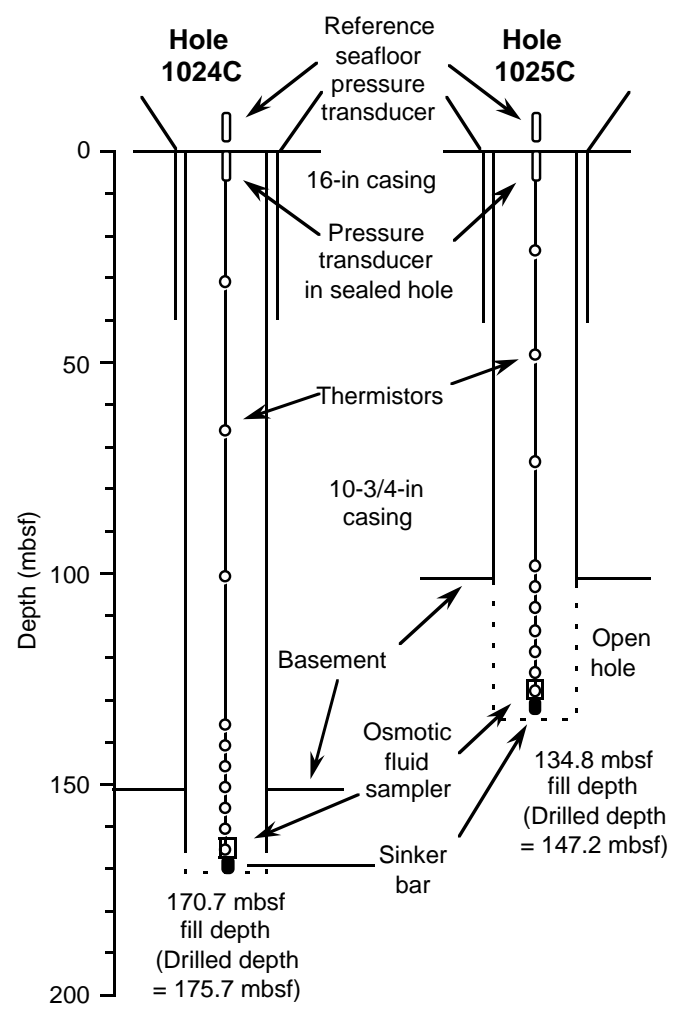

Figure 55. Configurations of the downhole sensor strings deployed in the CORK experiments in Holes 1024C and 1025C.

Table 25. Relevant time and depth data for the CORK experiments deployed in Holes $1024 \mathrm{C}$ and $1025 \mathrm{C}$.

\begin{tabular}{lcc}
\hline Hole: & 1024C & $1025 \mathrm{C}$ \\
Time/date of final basement coring (UTC): & $\begin{array}{c}\text { 1015 31 July } \\
\text { 0745 2 August }\end{array}$ & $\begin{array}{c}153028 \text { July } \\
140030 \text { July }\end{array}$ \\
Time/date CORK latched in cone (UTC): & & \\
\hline Depths (mbsf): & 151.7 & 101.0 \\
Basement & 165.7 & 102.0 \\
Casing shoe & 175.7 & 147.8 \\
Cored depth & 170.7 & 134.8 \\
Fill level at CORK deployment & 30.8 & 23.3 \\
T10 & 65.8 & 48.3 \\
T9 & 100.8 & 73.3 \\
T8 & 135.8 & 98.3 \\
T7 & 140.8 & 103.3 \\
T6 & 145.8 & 108.3 \\
T5 & 150.8 & 113.3 \\
T4 & 155.8 & 118.3 \\
T3 & 160.8 & 123.3 \\
T2 & 165.3 & 127.5 \\
T1 & 165.6 & 128.1 \\
OsmoSampler orifice & $165.8-169.3$ & $128.3-131.8$ \\
Sinker bar & & \\
\hline
\end{tabular}

Notes: $\mathrm{UTC}=$ Universal Time Coordinated. $\mathrm{T}=$ thermistor $(\mathrm{e} . \mathrm{g} ., \mathrm{T} 10=$ thermistor 10$)$. 